\title{
UM MÓDULO DE ANÁLISE DE SAÍDAS PARA O ASIA
}

\author{
Laís Lemos de Oliveira
}

\section{Orientadora:}

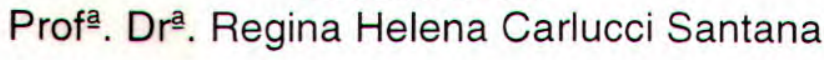

Área de Concentração:

Sistemas Distribuídos e Programação Concorrente

Dissertação apresentada ao Instituto de Ciências Matemáticas de São Carlos USP, como parte dos requisitos para obtenção do Título de Mestre em Ciências Área: Ciências da Computação e Matemática Computacional. 
Aqueles que realmente conhecem a natureza da existência, nada fazem em excesso. E porque nada fazem em excesso, satisfazem constantemente suas necessidades. $E$ ainda assim nada perdem.

Lao Tzu, Tao Teh King

A Willie e a todos os outros companheiros de jornada. 


\section{AGRADECIMENTOS}

A Deus, pela saúde, inteligência e capacidade para superar as dificuldades.

A Regina, pela orientação, compreensão e paciência.

Ao Marcos, pelo incentivo e amizade.

Ao professor Carlos Biasi, pelas longas conversas instrutivas.

À professora Rosângela Penteado, pela presença amiga em tantos momentos.

Aos meus pais, Dora e Nico, pela liberdade, pela educação e apoio aos meus objetivos.

Ao Toninho, pela presença constante e por tornar minha vida mais alegre.

A todos os amigos adquiridos durante o mestrado, Márcio, Mário, Flávio, Robson, Sarita, Roberta, Renata, Ana Elisa, Silmara, Rita; entre tantos outros, pela felicidade de tê-los conhecido, por tantos momentos descontraídos e tantos galhos quebrados. Aos colegas de sala, Chico, Cláudia e Renato, pelo silêncio e companherismo.

Aos funcionários deste instituto, pelos laços de amizade e por estarem sempre à disposiçāo em qualquer situação.

À Universidade de São Paulo, que possibilitou a realização deste mestrado.

À CAPES, pela concessão da bolsa de estudo.

Aos demais familiares e amigos e a todos que colaboraram para a realização deste trabalho. 


\section{Conteúdo}

Capítulo 1. Introdução.....................................................................

Capítulo 2. Técnicas para Análise de desempenho......................... 3

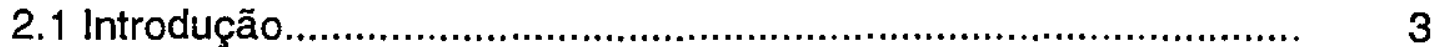

2.2 Anălise de Desempenho........................................................... 3

2.3 Técnicas para Análise de Desempenho..................................... 5

2.3.1 Técnicas de Aferição............................................................ 5

2.3.1.1 Coleta de Dados (Medição) .................................. 5

2.3.1.2 Benchmarks........................................................... 6

2.3.1.3 Construção de Protótipos....................................... 7

2.3.2 Técnicas de Modelagem.................................................... 8

2.3.2.1 Modelagem Analítica............................................. 9

2.3.2.2 Modelagem para Simulação................................... 9

2.4 Comentários Finais................................................................ 10

Capítulo 3. Modelagem e Slmulação................................................ 11

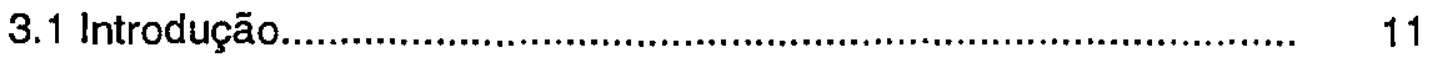

3.2 Definiçōes................................................................................... 11

3.3 Formulação de Modelos............................................................ 12

3.4 Simulação............................................................................. 14

3.4.1 Simulação Discreta........................................................... 14

3.4.1.1 Organização da Simulação.................................... 14

3.4.1.2 Fases da Simulação.............................................. 15

3.4.1.3 Vantagens e Desvantagens da Simulação............. 20

3.4.2 Simulação Contínua............................................................. 20

3.5 Modelos de Redes de Filas......................................................... 21

3.5.1 Aspectos dos Sistemas de Filas........................................ 22

3.5.2 Caracterização de um Sistema de Filas.............................. 22

3.5.2.1 O processo de chegada........................................ 22

3.5.2.2 O processo de serviço............................................ 23

3.5.2.3 Disciplina da fila.................................................. 24

3.5.2.4 Capacidade do Sistema...................................... 24

3.5.2.5 Número de Servidores.......................................... 24

3.5.3 Notação para um Sistema de Filas...................................... 24

3.6 Números Aleatórios.................................................................. 25

3.7 Exemplo de Simulação Manual de uma situação real.................. 26

3.8 Exemplo de Simulação para Análise de Desempenho................. 27

3.9 Comentários Finais............................................................... $\quad 30$ 


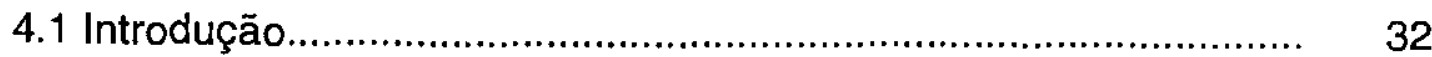

4.2 Ambientes de Simulação....................................................... 32

4.2.1 Linguagens de Uso Geral.............................................. 33

4.2.2 Linguagens de Simulação................................................ 33

4.2.3 Pacotes de Simulação....................................................... $\quad 35$

4.2.4 Extensões Funcionais...................................................... 35

4.2.5 Sistemas Automáticos.................................................... 35

4.3 O ASiA (Ambiente de Simulação Automático) ............................ 36

4.3.1 O Editor Gráfico do ASiA ................................................ 37

4.3.2 Geradores de Aplicação ................................................ 38

4.3.3 O Gerador de Aplicações para o ASiA .............................. $\quad 39$

4.3.4 O Estágio de Saída ......................................................... $\quad 40$

4.4 Outros Sistemas Automáticos.................................................. 40

4.5 Comentários Finais............................................................ 42

Capítulo 5. Análise dos Resultados............................................... 44

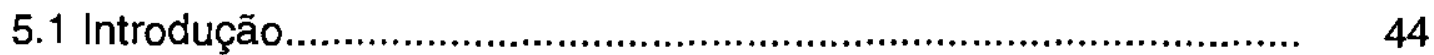

5.2 Considerações Teóricas........................................................... 44

5.2.1 Tipos de Simulação.......................................................... 44

5.2.2 Medidas Usuais de Interesse........................................ $\quad 45$

5.2.3 Intervalos de Confiança.................................................... 48

5.2.4 Correlação entre os Dados Amostrais................................ 50

5.2.5 Considerações sobre a Normalidade................................ 51

5.2.6 Teste de Hipóteses.......................................................... 52

5.3 Análise das Saídas............................................................... 52

5.3.1 Estimação do Intervalo de Confiança.................................. 53

5.3.1.1 Procedimento da Amostra de tamanho Fixo............ 53

5.3.1.2 Procedimento Seqüencial..................................... 53

5.3.2 O periodo transiente ("Warm up") ................................... 54

5.3.3 Métodos de Análise de Saídas........................................ $\quad 55$

5.3.3.1 Método da Replicação........................................ $\quad 55$

5.3.3.2 Método das Médias dos Lotes (Batch Means)...... 57

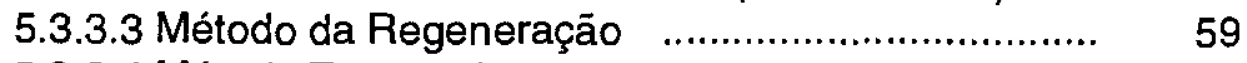

5.3.3.4 Método Espectral................................................ 60

5.3.3.5 Métodos de Redução da Variância........................ $\quad 60$

5.4 Análise Estatística dos Resultados........................................... 63

5.5 Comentários Finais............................................................. 64

Capítulo 6. Avaliação dos Métodos de Análise de Saídas 66 utillizados em ambiente de simulação..

6.1 Introdução 66

6.2 Aspectos mais tratados em Análise de Saídas........................... 66

6.3 Outras técnicas presentes na literatura..................................... $\quad 70$

6.3.1 Técnica Heurística.......................................................... 71 
6.3.1.1 Descrição da Técnica............................................. 71

6.3.1.2 Algumas consideraçōes sobre esta técnica............ 72

6.3.1.3 Vantagens e Desvantagens................................ 73

6.3.2 Método Bootstrap.......................................................... 73

6.3.2.1 Descrição da técnica........................................... 74

6.3.2.2 Exemplo.......................................................... $\quad 76$

6.3.2.3 Vantagens e Desvantagens................................ $\quad 76$

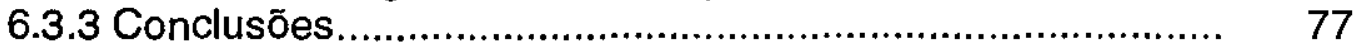

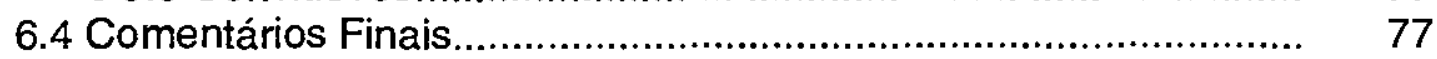

Capítulo 7. Escolha e Adaptação dos Métodos de Análise de Saídas para o ASiA ......................................................................... 79

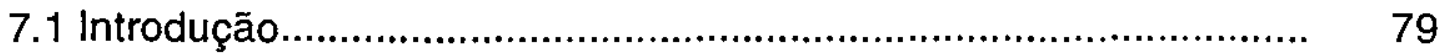

7.2 Definição do Módulo de Análise de Saídas..................................... 79

7.3 Implementação dos Métodos e Exemplos................................... 81

7.3.1 Ambiente de Desenvolvimento.......................................... 81

7.3.2 Método das Replicações................................................... $\quad 82$

7.3.3 Método Batch Means...................................................... $\quad 85$

7.3.4 Cálculo do Intervalo de Confiança para Múltiplas Variáveis . $\quad 89$

7.3.4.1 Variáveis Múltiplas para a simulação de um único modelo................................................................. 89

7.3.4.2 Comparação entre dois sistemas utilizando técnicas de Redução da Variância......................................... 93

7.4 Estratégias para inclusão no ASiA............................................... 95

7.4.1 Alterações no Editor Gráfico............................................. 95

7.4.2 Alterações no Gerador de Aplicações................................. 104

7.4.3 Comentários sobre a Implementação da Técnica

Heurística e do Método Bootstrap................................... 113

7.5 Comentários Finais............................................................ 113

Capítulo 8. Conclusões e Trabalhos Futuros.................................. 115

8.1 Introdução.............................................................................. 115

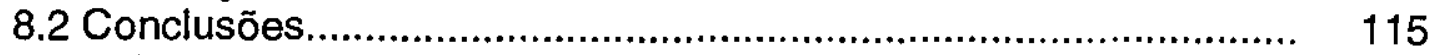

8.3 Dificuldades Encontradas......................................................... 116

8.4 Contribuições deste trabalho................................................... 116

8.5 Sugestões para trabalhos futuros............................................ 117

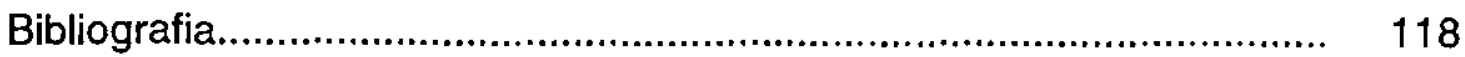

Apêndice A . Listagem dos códigos-fonte dos programas do módulo de análise de saídas................................... 121

Apêndice B. Listagem dos Códigos-fonte de algumas rotinas do Gerador de Aplicação do ASiA. 


\section{Lista de Figuras}

Figura 2.1 Sistema computacional e subsistemas.................................. 4

Figura 2.2 Estágios na construção de protótipos..................................... 8

Figura 3.1 Interpretação do significado de um modelo............................... 13

Figura 3.2 Refinamento do modelo..................................................... 13

Figura 3.3 Fases de uma simulação..................................................... 17

Figura 3.4 Estrutura básica de um sistema de filas.................................. 22

Figura 3.5 Sistemas de Filas............................................................ 23

Figura 3.6 Relatório produzido pela simulação manual.............................. 28

Figura 3.7 Representação do sistema de filas do exemplo......................... 28

Figura 3.8 Programa de simulação em smpl para o modelo do exemplo..... 29

Figura 3.9 Relatório apresentado pelo programa do exemplo.................... 30

Figura 4.1 Funcionamento Básico do ASiA............................................. 36

Figura 4.2 Visão Geral do EdGraf........................................................ 38

Figura 4.3 Relação entre os módulos do gerador..................................... 39

Figura 4.4 As fases no processo de execução.......................................... 41

Figura 5.1 Processo de divisão da rodada em lotes................................ 58

Figura 5.2 Número de clientes pelo tempo num processo regenerativo.... 60

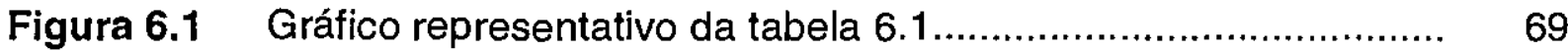

Figura 6.2 Histograma correspondente à distribuição de freqüências

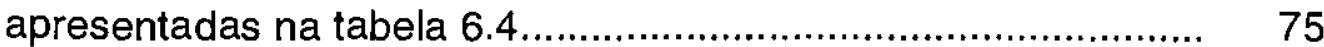

Figura 7.1 Relatório das Saídas da Simulação pelo Método das Replicações

Figura 7.2 Relatório padrão do smpl para a execução do modelo do exemplo do método das Replicações......................................... $\quad 85$

Figura 7.3 Relatório das Saídas da Simulação pelo Método Batch Means...

Figura 7.4 Relatório padrão do smpl para a execução do modelo do exemplo do método Batch Means. 
Figura 7.5 Relatório das Saídas da Simulaçāo para Múltiplas Variáveis (Método das Replicações)

Figura 7.6 Relatório padrão do smpl para a execução do modelo do exemplo do método das replicações para Múltiplas variáveis....

Figura 7.7 Relatório das Saídas da Simulaçāo para Múltiplas Variáveis (Método Batch Means).

Figura 7.8 Relatório padrão do smpl para a execução do modelo do exemplo do método Batch Means para Múltiplas variáveis........ 93

Figura 7.9 Relatório para comparação entre as médias dos dois modelos...

Figura 7.10 Janela "Método de Anállse".................................................... 96

Figura 7.11 Janela "Parâmetros de Anállse" para o método das replicações. $\quad 97$

Figura 7.12 Janela "Parâmetros de Análise" para o método Batch Means.... 97

Figura 7.13 Janela "Variável para Anállse" ................................................ 98

Figura 7.14 Janela "Parâmetros Complementares" para Múltiplas Variáveis.. 99

Figura 7.15 Janela "Facillty para Análise" ................................................ 99

Figura 7.16 Janela "Redução de Variância" (usada na comparaçāo de 100 sistemas)

Figura 7.17 Sub-menu "Outros" 100

Figura 7.18 Novo Gabarito utilizado......................................................... 105

Figura 7.19 Código-fonte da rotina Gera_Método_Analise_Saida................ 106

Figura 7.20 Código-fonte da rotina Define_Param_Analise.......................... 107

Figura 7.21 Código-fonte da rotina Gera_Loop.......................................... 108

Figura 7.22 Código-fonte da rotina Gera_Num_Aleat_Comuns..................... 108

Figura 7.23 Código-fonte da rotina Gera_Obs_Valores............................... 109

Figura 7.24 Código-fonte da rotina Gera_Relat_Analise............................ 110

Figura 7.25 Código-fonte da rotina Gera_Gravação_Resultados.................. 112 


\section{Lista de Tabelas}

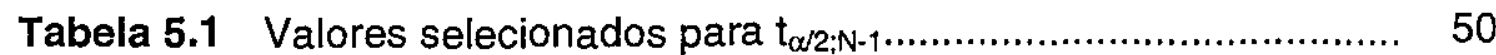

Tabela 5.2 Tamanhos de amostra conforme a intensidade de tráfego

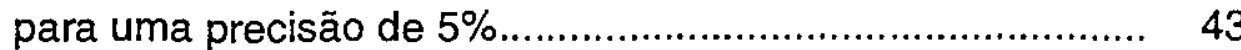

Tabela 6.1 Principais aspectos de análise de saídas e sua utilização nos softwares de simulação............................................... 68

Tabela 6.2 Comparação entre as proporções de aspectos apresentados pelos softwares analisados............................................... 69

Tabela 6.3 Reamostras obtidas a partir da amostra original 1,2,3,4,5.... 75

Tabela 6.4 Distribuição de freqüências.............................................. 75

Tabela 6.5 Medianas obtidas para os sistemas em cada replicação....... 76

Tabela 6.6 Valores obtidos para as medianas em cada sistema e as correspondentes soluções analíticas conhecidas................. 76

Tabela 7.1 Valores obtidos durante a simulação segundo o método das replicações

Tabela 7.2 Valores obtidos durante a simulação segundo o método Batch Means.

Tabela 7.3 Resultados da comparação entre as médias dos dois sistemas.

Tabela 7.4 Correspondência entre os campos de análise e os parâmetros dos métodos 


\section{Resumo}

Este trabalho apresenta a definição de um módulo de análise de saídas para o ASiA (Ambiente de Simulação Automático desenvolvido pelo grupo de Sistemas Distribuídos e Programação Concorrente do ICMSC-USP).

O objetivo deste módulo de análise de saídas é proporcionar ao usuário do ASIA uma ferramenta para validar os resultados de sua simulação, através do cálculo do intervalo de confiança para a média de uma dada medida de interesse. Os métodos estatísticos adotados são replicações e batch means para variáveis simples $\theta$ múltiplas. Além destes métodos, considera-se ainda um método para comparação entre sistemas utilizando-se diferenças entre médias.

Diversos métodos estatísticos são revisados nesta dissertação, sendo que a escolha dos que compõem o módulo de análise foi efetuada adotando-se diversos critérios.

Os métodos escolhidos foram testados (os diversos programas que compōem o módulo são apresentados), exemplificados e discutida sua integração com o ASIA. 


\section{Abstract}

This work presents the definition of an output analisys module for ASiA (an Automatic Simulation Environment developed by the Distributed Systems and Concurrent Programming group at the ICMSC-USP).

The aim of this output analisys module is to offer to the ASiA's user a tool to validate the simulation results, by means of confidence interval evaluation for the average value of a given measure of interest.

The statistical methods adopted are the repplication and the batch means analisys for simple and multiple variables. Furthermore, another technique used deal with system comparison by means of the difference between mean values.

Several statistical methods are revised in this dissertation and the choice of the ones used for the output analisys module was done by adopting many criteria.

The methods chosen were tested (the several programs developed are presented), exemplified and their integration to ASiA is also discussed. 


\section{CAPÍTULO 1}

\section{Introdução}

A rápida evolução dos computadores desde os primeiros e gigantescos modelos até os atuais, muito poderosos e bastante reduzidos em tamanho, é algo impressionante. Desde 1960, eles vêm se tomando cada vez menores, muito mais baratos, poderosos e fáceis de usar por qualquer pessoa, expandindo consideraveimente a área de trabalho para os mais diversos tipos de usuários [PID92].

Com essa evolução, foi se tornando cada vez mais importante o aprimoramento de técnicas para análise de desempenho dos sistemias computacionais. Neste sentido, os métodos de simulação computacional vêm se desenvolvendo ao longo do tempo, paralelamente ao desenvolvimento dos computadores, desde 1960. Isto tem contribuído, e muito, para que a simulação seja um dos métodos de análise preferido da maioria, em detrimento, por exemplo, dos métodos analíticos. Estes últimos, em geral, são sempre aconselhados devido à precisão de seus resultados, mas, a facilidade de uso faz com que os usuários dêem preferência à simulação [PID92].

Quando aplicada à análise de desempenho de sistemas computacionais, a simulação, da mesma forma que outros métodos de análise, proporciona tanto a construção de sistemas de maior qualidade, pois os resultados dele poderão ser avaliados $\theta$ modificados antes de sua construção efetiva, como a elucidação de problemas de funcionamento que os sistemas em operação porventura apresentem [HAR88].

A utilidade dos resultados da simulação depende de muitos fatores. O primeiro deles, é, sem dúvida alguma, a modelagem. Se o modelo não representa adequadamente o sistema, de nada adiantará o trabalho dispensado na obtenção de um conjunto apreciável de resultados, pois eles não ajudarão muito para o estudo do sistema. Isto serve para qualquer outro método de análise que envolva modelagem. Pode-se dizer que a precisão de qualquer estudo de desempenho depende da qualidade do modelo e da qualidade da representação utilizada para a carga de trabalho [THE94].

Outro fator capaz de comprometer a importância dos resultados obtidos através de uma simulação é a análise das saídas. Embora a maioria dos usuários concordem com a importância da análise das saídas, poucos são os que realmente estão aptos a fazê-la. É muito comum, os usuários tirarem conclusões sobre o comportamento de um sistema baseados apenas nos resultados obtidos a partir de uma rodada de simulação. Este comportamento precipitado é muito perigoso, pois o resultado de uma rodada de simulação representa apenas um dos muitos resultados possíveis do experimento, uma vez que trata-se de um processo aleatório [BAN96].

Também os softwares de simulação costumam apresentar uma tendência a ignorar o aspecto da análise de saídas, deixando esta tarefa a cargo do usuário. Porém, muitos produtos da atualidade vêm integrando aspectos de análise de saídas, diminuindo o esforço do usuário neste sentido. 
O ASiA (Ambiente de Simulação Automático) é um sistema desenvolvido pelo grupo de Sistemas Distribuídos e Programação Concorrente do ICMSC-USP que automatiza a geração de programas de simulação. Neste sistema, os usuários descrevem seus modelos através de um editor gráfico, introduzindo os parâmetros necessários através de caixas de diálogo. O estágio atual do ASiA inclui os módulos editor gráfico, gerador de aplicações e visualização dos resultados. O ASiA ainda não possui um módulo de análise de resultados.

O objetivo deste trabalho é a integração dos principais aspectos da análise de saídas ao ASiA, acrescentando a ele um novo módulo, o módulo de análise de saídas, de forma a consolidar uma de suas metas básicas: torná-lo acessível a usuários das mais variadas áreas e não apenas aos relacionados com a área acadêmica ou familiarizados com simulação.

Assim, para o desenvolvimento do trabalho proposto foi necessário uma revisão bibliográfica sobre simulação e principalmente sobre análise de saídas de sistemas de simulação.

Esta dissertação de mestrado consiste de oitos capítulos. O capítulo 2 apresenta aspectos da análise de desempenho de sistemas computacionais, uma área de aplicação de grande importância para este trabalho.

O capítulo 3 trata basicamente da simulação, discutindo todos os seus aspectos importantes e enfocando também o modelo de redes de filas, muito empregado na análise de desempenho.

O capítulo 4 apresenta os diversos ambientes existentes para simulação, variando desde as linguagens comuns de programaçāo até os sistemas automáticos, os quais geram programas de simulação a partir do modelo e de seus parâmetros. Neste capítulo, é dado um destaque especial ao ASiA (que será - ambiente hospedeiro deste trabalho), apresentando suas principais características.

O capítulo 5, enfoca os principais aspectos da análise de saídas como: intervalos de confiança, correlação, técnicas de análise de saídas (replicação, Batch Means, regeneração, etc.), técnicas de redução de variância (variáveis de controle, variáveis antitéticas, números aleatórios comuns, etc.), problema de warm up, etc. Estes conceitos são a base para desenvolvimento do módulo já mencionado.

O capitulo 6, apresenta um estudo sobre quais métodos são realmente implementados em análise de saídas nos principais softwares de simulação, gerando a base para a seleção dos métodos a serem implementados. Além disso, discute algumas técnicas recentes para a simulação de sistemas.

O capítulo 7, apresenta os critérios adotados para a escolha e implementação das métodos para o desenvolvimento do módulo de análise de saídas e um estudo para a sua integração ao ASiA.

O capítulo 8, apresenta as conclusões finais deste trabalho, suas contribuições, as dificuldades encontradas durante a sua realização e sugestões para trabalhos de pesquisa futuros.

Finalmente os apêndices $A$ e $B$, apresentam os códigos dos programas desenvolvidos e as alterações feitas nos programas do ASiA, respectivamente. 


\section{CAPÍTULO 2}

\section{Técnicas para análise de desempenho}

\subsection{Introdução}

Em muitos aspectos da vida diária, surge com freqüência a necessidade de se medir o desempenho de um dado sistema, seja ele, um equipamento doméstico, um esquema de atendimento ao público, um sistema computacional, etc. O objetivo desta medida pode ser a detecção de pontos críticos no sistema, a comparação entre sistemas com a finalidade de se escolher aquele que apresentar melhor desempenho, etc.

Em sistemas computacionais, análise de desempenho tem uma importância bastante significativa quando se considera a implementação e a utilização dos mesmos [ORL95]. Geralmente, o usuário costuma avaliar o desempenho dos sistemas em termos dos tempos de resposta apresentados por eles, o que de certa forma, ao menos mede o grau de satisfação do usuário. Outros parâmetros, tais como, throughput e tempos de espera em filas, podem também ser considerados.

Neste capítulo, serão apresentadas as técnicas freqüentemente empregadas para análise de desempenho, sendo que, a escolha entre elas deve levar em consideração a adeqüabilidade, a facilidade de uso, a flexibilidade, o custo, o tempo gasto, tanto para desenvolvimento, como para aprendizagem, a precisão dos resultados, etc.

\subsection{Análise de Desempenho}

Denomina-se análise de desempenho à obtençāo e análise de medidas que revelam a taxa na qual os sistemas realizam trabalho, tendo o tempo como uma variável independente [MAC87]. Em outras palavras, é a análise da relação entre a quantidade de serviços prestados e o tempo gasto.

Como já mencionado anteriormente, seus principais propósitos são:

- Auxiliar no projeto de hardware e de software;

- Auxiliar na seleção de sistemas existentes;

- Indicar as características a serem alteradas para o desempenho de um sistema existente.

Medir e avaliar o desempenho de um sistema computacional não é uma tarefa simples, devido à complexidade da estrutura intema dos mesmos e à dificuldade em descrever e predizer a carga de trabalho que será submetida a ele. Um sistema computacional é composto de subsistemas, cada um dos quais podendo ser visto como um sistema com sua própria carga de trabalho e desempenho. $O$ desempenho do sistema como um todo está relacionado ao 
desempenho dos subsistemas, embora esta relação possa ser complexa, conforme mostra a figura 2.1 [MUN95].

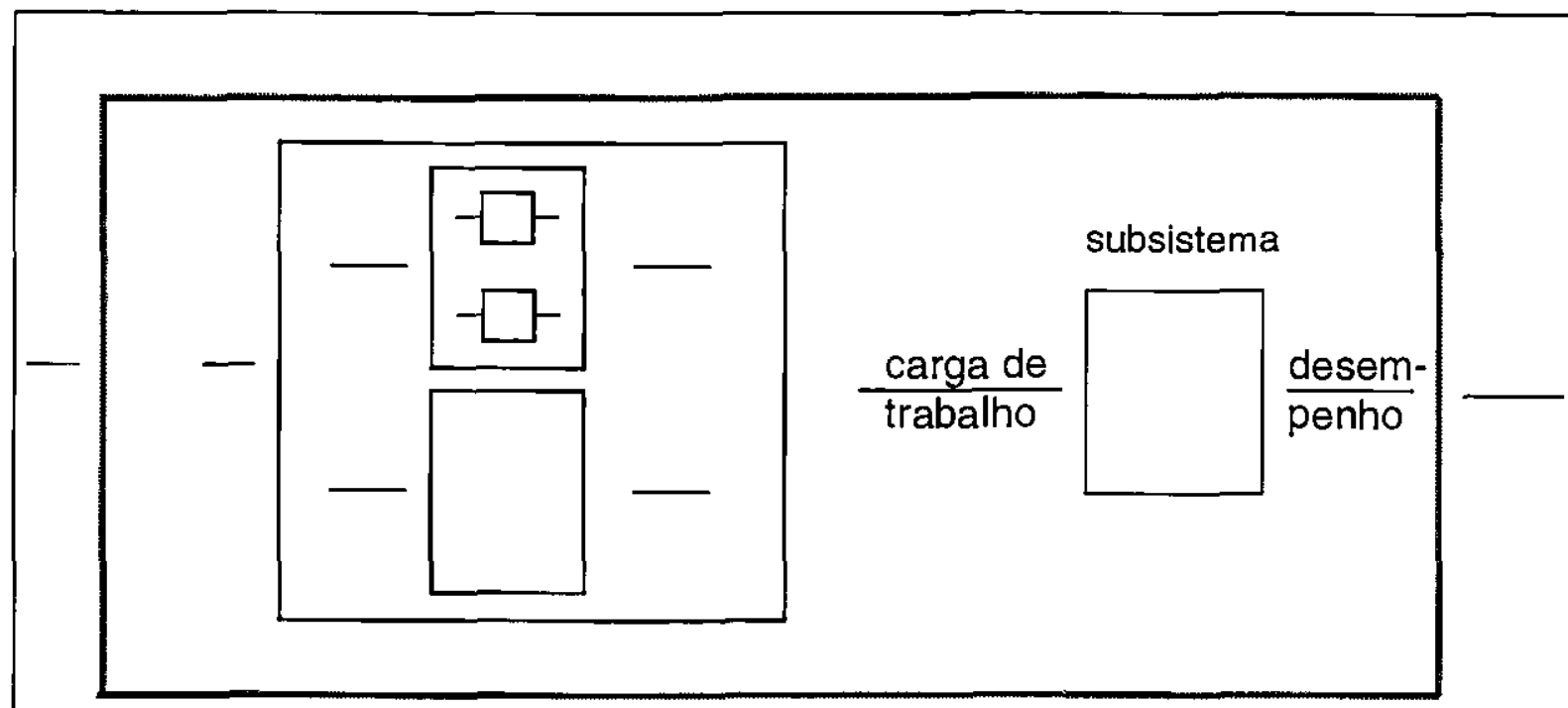

Figura 2.1: Sistema Computacional e subsistemas.

A análise de desempenho deve estar relacionada às aplicações que serão consideradas no sistema a ser avaliado. Um indice representativo do desempenho de um sistema pode ser considerado excelente para uma aplicação, enquanto este mesmo valor pode ser considerado totalmente insatisfatório quando representando o desempenho do mesmo sistema, considerando outras aplicaçōes.

A análise de desempenho é útil desde o projeto do sistema até a fase relativa à sua operação diária. Ainda na fase de projeto, deve-se prever o comportamento futuro do sistema, permitindo que, caso seja necessário, hajam modificações no mesmo, antes de seu desenvolvimento. Isto pode evitar que sistemas com desempenho insatisfatório sejam implementados e postos em atividade, economizando, desta forma, tempo e dinheiro. $\mathrm{Na}$ fase de uso, a análise de desempenho pode ser utilizada na maximização da utilização de um dado recurso, no processamento de uma carga de trabalho a um custo mínimo, na minimização dos tempos de resposta, etc. [ORL95].

Outra atuação importante na análise de desempenho ocorre na comparação de mais de um sistema (existente ou em fase de projeto) com o intuito de escolher o mais adequado.

As medidas obtidas na análise de desempenho classificam-se em:

- medidas orientadas ao usuário: baseiam-se no tempo de ciclo, (turnaround) que é o tempo decorrido desde o pedido de execução da tarefa até a obtenção dos resultados;

- medidas orientadas ao sistema: baseiam-se na capacidade de trabalho e na sua utilização (throughput). 


\subsection{Técnicas para análise de desempenho}

Diferentes técnicas para análise de desempenho estão disponíveis $e$ representam os meios de extração de informações a partir do sistema. A escolha da técnica mais adequada deve ser feita através da análise do sistema a ser avaliado, do tipo de avaliação a ser efetuado e da fase em que o sistema se encontra. Assim, as técnicas devem ser adequadamente analisadas, com o objetivo de obter respostas válidas sobre as tendências comportamentais do sistema.

As técnicas de análise de desempenho podem ser divididas em dois grupos conforme a maneira pela qual os dados são obtidos: diretamente do próprio sistema (técnicas de aferição) ou a partir de modelos representativos do sistema (técnicas de modelagem) [ORL95].

\subsubsection{Técnlcas de Aferição}

São técnicas apropriadas à experimentação direta do sistema, podendo ser aplicadas sobre o próprio sistema ou sobre um protótipo, através de hardware ou software adequado.

Apresentam resultados bastante precisos, mas, em compensação possuem algumas desvantagens, tais como:

- necessidade da existência do sistema ou protótipo;

- podem influenciar diretamente nos resultados obtidos prejudicando a análise;

- podem causar a interrupção do uso do sistema;

- dificultam a análise de altemativas para o sistema [ORL95].

Abaixo serão apresentadas as principais técnicas de aferição: coleta de dados, benchmarks e protótipos.

\subsubsection{Coleta de Dados (Medição)}

Trata-se da técnica mais indicada para análise de desempenho de sistemas computacionais, tida como a que produz os resultados mais precisos. Em geral, é realizada sobre um sistema real, operando sob condições normais. Daí, advém uma de suas desvantagens, que é a necessidade de que o sistema a ser avaliado já esteja em atividade. Uma outra desvantagem é que muitas vezes seu uso pode interferir diretamente no funcionamento do sistema gerando interpretaçōes enganosas dos resultados obtidos [ORL95].

Pode ser feita através de monitores de hardware ou de software:

- Monitores de Hardware : são construções de hardware conectadas ao sistema, específicas para a medição de sinais elétricos, como os analisadores lógicos, por exemplo. Geralmente não utilizam os recursos do sistema, limitando-se apenas à leitura de sinais, não promovendo sua modificação. Possuem capacidade de medição de desempenho limitada, por isso, são bastante úteis quando o número de sinais a serem medidos é limitado. Quando 
este número é muito grande, sua capacidade de medição pode ser excedida e resultados inesperados e incorretos podem ser obtidos. Apresentam também, dificuldade em coletar informações relacionadas ao software, por exemplo, política de escalonamento da CPU, alocação de memória, etc. [ORL95].

- Monitores de Software: são programas executados no sistema que competem com os sistemas em medição [SOA92]. Podem produzir informações mais detalhadas sobre a operação do sistema, embora possam perturbar os valores medidos. Solucionam o problema acima mencionado na obtenção de informaçōes acerca do comportamento do software. Podem ser de dois tipos: monitores orientados a eventos ou monitores de amostragem [KOB81,ORL95]. Monitores orientados a eventos são aqueles que disparam rotinas no sistema conforme a ocorrência de eventos (por exemplo, ocorrência de interrupção da CPU). Podem sobrecarregar o sistema, consumindo tempo de CPU, memória e canal para transferência de dados, gerando a degradação do funcionamento do sistema durante a coleta de dados e assim interferindo nos resultados da análise [ORL95]. Monitores de amostragem [KOB81] são aqueles em que o monitor de software chama uma rotina em intervalos regulares, permitindo que o processador seja interrompido por um temporizador interno. Nestes instantes, o rnonitor inspeciona o conteúdo das tabelas residentes na memória contendo informaçōes sobre o uso dos recursos no sistema, programas e atividades. Esta abordagem provoca um conflito entre a resolução e a degradação, uma vez que quanto maior a taxa de amostragem requerida (maior a resolução), mais o monitor vai interferir no desempenho do sistema (maior a degradaçāo). Outro problema que pode ocorrer é que muitos eventos podem ser passados despercebidos pelo monitor. Podem ser utilizados em conjunto com os monitores orientados a eventos.

\subsubsection{Benchmarks}

Suponha que se deseje comparar o desempenho de dois sistemas através da técnica anterior de coleta de dados. Para isto, deve-se submeter ambos os sistemas a uma mesma carga de trabalho. Esta, por sua vez, pode ser uma aplicação qualquer ou um programa elaborado especificamente para esta finalidade. A este programa ou aplicação, denomina-se benchmark. Benchmark é um programa, escrito em uma linguagem de alto nível, que submete o sistema a uma determinada carga de trabalho ou tarefa e mede os resultados obtidos comparativamente a outros sistemas medidos de maneira idêntica. Esta técnica é ideal para a comparação entre dois ou mais sistemas com o objetivo de se escolher o de melhor desempenho.

Os benchmarks são usados para medir aspectos gerais do sistema, tais como: desempenho de aplicações gráficas, de $1 / O$, de computação inteira e de ponto flutuante, da leitura e escrita de arquivos, de operações sobre matrizes, etc. Mas, a rnaioria deles apresenta tendências em representar uma certa área de aplicação. Por isso, ao se escolher um benchmark é necessário argumentar sobre sua adequação aos propósitos do sistema, sem se deixar levar pela popularidade deles. Alguns fabricantes, a título de competição por mercado, costumam aperfeiçoar seus equipamentos de modo a obter maior desempenho em relação a um dado benchmark. 
Os benchmarks, além de testar o desempenho do kernel e também das aplicações científicas, podem ser usados para outros propósitos: como ferramenta de diagnóstico, para se descobrir a causa de um desempenho ruim e para medir o impacto que uma determinada mudança pode causar ao sistema.

Normalmente, os benchmarks fornecem os resultados de suas medidas em MIPS (Milhões de Instruções Por Segundo), porém, com o advento das máquinas RISC, esta medida deixou de ser significativa, uma vez que são necessárias muitas instruções RISC para compor uma única instrução CISC. Isto gerou 0 aparecimento de várias medidas derivadas do MIPS. Outra medida bastante utilizada é o MFLOPS (Milhões de Instruções de ponto Flutuante por segundo).

Os benchmarks mais populares atualmente são [WE|90]: Wheatstone, Dhrystone, Linpack, SPEC. O benchmark NAS [NAI95] é adequado para avaliação de desempenho de sistemas paralelos. Como exemplo de outros benchmarks, tem-se: 007 (ODBMS), AIM, KhornerStone, NhfStone, RhosettaStone, etc.

\subsubsection{Construção de Protótipos}

Construção de protótipos é uma técnica útil quando se deseja medir o desempenho de um sistema ainda não disponivel. Construir o sistema, correndose o risco de o produto final ter desempenho insatisfatório é algo indesejado, pois isso tem um alto custo, além de consumir tempo e pessoal. Além disso, muitas alternativas para a construção do sistema nāo são analisadas. Assim, ao invés de se construir o sistema todo, protótipos contendo as características essenciais do sistema são construídos, a um custo bem menor que o sistema real e permitindo a análise de altemativas para o sistema, bem como a detecção e solução antecipada de situaçōes conflitantes.

Assim, os protótipos não passam de uma versão simplificada do sistema real [FER92], ou seja, uma versão funcional [ORL95].

A construção de protótipos também apresenta altos custos. Maior o número de alterações no protótipo, maior o seu custo. Assim, seu uso é mais indicado como ferramenta para verificação do projeto final ou então para verificação de um sistema existente, onde poucas modificaçōes são necessárias [ORL95].

Segundo Harker [HAR88], o processo de construção de protótipos constitui-se de vários estágios, sendo que alguns deles são constituídos por atividades que ocorrem em paralelo, como mostra a figura 2.2 .

Uma vez tendo definido o que se deseja testar com o protótipo, é necessário desenvolver o suporte técnico para os aspectos de interface, incluindo as tarefas e material de suporte. Também é necessário definir a população de usuários envolvidos no sistema, pois, dependendo dos objetivos, pode-se afetar diferentes grupos de usuários. A forma como os dados serão coletados, é o próximo passo, bem como as estratégias utilizadas com essa finalidade.

A seguir, o protótipo é desenvolvido, analisado e interpretado. A partir destas interpretaçōes, são feitas especulações sobre o sistema futuro. A etapa seguinte é a revisão do protótipo de forma a verificar se todos os objetivos foram atingidos e também reproduzir no protótipo possíveis mudanças. 


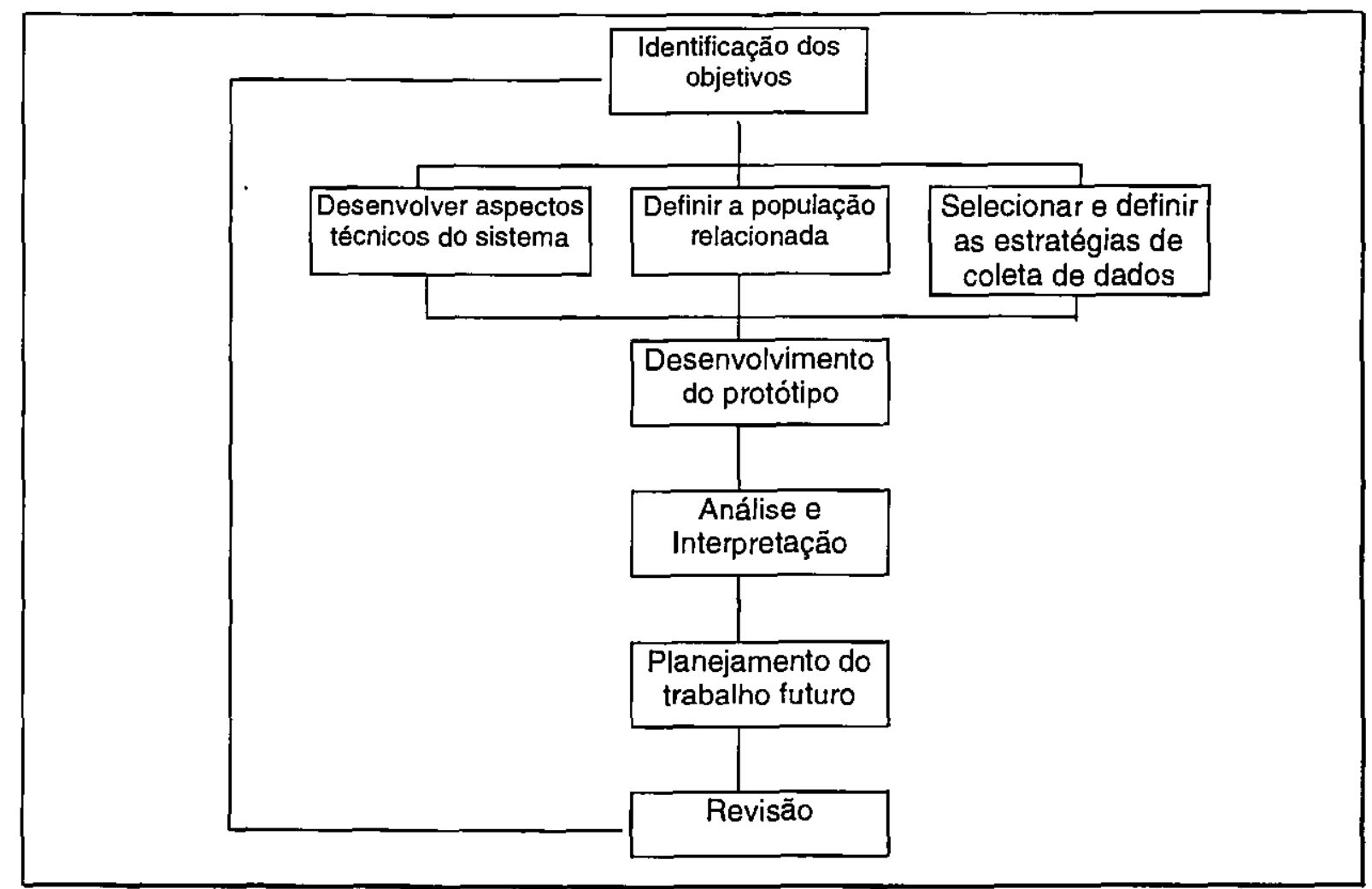

Figura 2.2: Estágios da construção de protótipos

\subsubsection{Técnicas de Modelagem}

Conforme será visto com mais detalhes no capítulo seguinte, as técnicas de modelagem são aquelas utilizadas quando não se dispõe nem do sistema e nem de um protótipo para se efetuar medidas de desempenho. Desta forma, torna-se necessária a construção de um modelo que represente o sistema em suas características essenciais. $O$ estudo deste modelo, e a conseqüente obtenção e avaliação dos índices de desempenho são feitos através das técnicas de modelagem analítica ou de modelagem para simulação [FER92], as quais serão sucintamente descritas a seguir e tratadas mais detalhadamente no próximo capítulo.

Segundo Mitrani [MIT92], os métodos de modelagem, de maneira geral, podem fornecer soluções analíticas ou numéricas. As soluçōes analíticas fornecem uma expressão matemática para as características do sistema em termos dos parâmetros de definição. Normalmente, apenas os modelos mais simples têm soluções desta forma. As soluções numéricas, ao contrário, podem ser aplicadas a modelos de qualquer nível de complexidade, sendo divididos em métodos determinísticos e métodos estocásticos, dependendo da ausência ou presença de variáveis aleatórias no modelo, respectivamente. $O$ método de simulação, que será abordado neste trabalho, é um método numérico estocástico. 


\subsubsection{Modelagem Analítica}

A modelagem analítica descreve as operações $\theta$ a carga de trabalho de um sistema por meio de equações matemáticas [FER92] as quais, dependendo da complexidade inerente ao problema podem até mesmo não ter solução.

Muitas vezes, porém, o modelo obtido pode ser bastante simples $\theta$ bem representativo do sistema, gerando solução fácil, bastante precisa $\theta$ a um baixo custo. Outras vezes, o modelo pode nāo representar bem o sistema em estudo, devido ao grande número de simplificações necessárias para tomá-lo solúvel, gerando resultados pouco significativos [SOA92].

Os modelos podem ser representados de diferentes formas conforme a adequação a cada problema e a experiência e conhecimento do modelador:

- cadeias de Markov: baseado na determinação dos estados do sistema e na probabilidade de mudança de um estado para o outro;

- redes de filas: quando se tem um conjunto de centros de serviço (representando os recursos do sistema) e vários clientes podendo estar utilizando um recurso ou aguardando em uma fila;

- redes de Petri: representando paralelismo e sincronismo de atividades [FER92], conforme a adequação a cada problema e à experiência e conhecimento do modelador.

\subsubsection{Modelagem para Simulação}

Simulação compreende a reprodução ou representação de um objeto ou sistema [ORL95]. Como os sistemas normalmente sofrem mudanças ao longo do tempo, seu comportamento dinâmico deve ser representado na simulação. O que ocorre com freqüência é o emprego de um processo computacional para implementar o modelo de algum fenômeno ou sistema dinâmico [ORL95].

O comportamento dos sistemas é influenciado por eventos aleatórios que ocorrem ao longo do tempo, tratando-se, portanto, de um processo estocástico (ou de Monte Carlo) e dinâmico [MIT92].

Como na modelagem analítica, também faz-se necessária a presença de um modelo para o sistema, que será utilizado na construção de um programa de simulação que o represente de forma adequada para a máquina em que será executado.

Entre as vantagens da utilização da simulação, figuram a flexibilidade, a facilidade de utilização e o custo relativamente baixo [ORL95]. É adequada a modelos em qualquer nível de detalhe [FER92] e a facilidade de utilização mencionada acima, deve-se em grande parte às diversas linguagens especificamente criadas para esta finalidade.

Segundo [SAN94a], da mesma forma que nos métodos analíticos, a principal preocupação deste método é a validação dos resultados obtidos, pois de nada adianta um volume impressionante de dados produzidos se o modelo não representa adequadamente o sistema.

O próximo capítulo é inteiramente dedicado à simulaçāo. 


\subsection{Comentários Finais}

A análise de desempenho tem aumentado em importância à medida em que se tornam maiores as opçōes por sistemas diferentes e à medida em que aumenta a complexidade, o custo e a necessidade por melhores desempenhos.

Muitas técnicas têm sido desenvolvidas para esta finalidade e sua aplicação está sujeita a fatores tais como: disponibilidade ou não do sistema a ser analisado, custo, precisão, experiência do modelador, facilidade de uso, etc.

As técnicas de aferição, produzem resultados precisos, mas em alguns casos são caras e requerem a existência do sistema ou de um protótipo.

As técnicas de modelagem, de custo mais baixo, não requerem a existência do sistema, mas a precisão de seus resultados depende da exatidão com que o modelo representa os aspectos do sistema relevantes ao estudo. Entre elas, tem-se as técnicas de modelagem analítica, as quais apresentam soluçōes bastante precisas para 0 modelo baseado em equações matemáticas, porém, dependendo de sua complexidade pode não ter solução. As técnicas de modelagem para simulação podem ser aplicadas a sistemas bastante complexos, sendo que as simplificações adotadas dependem do nível de detalhamento requerido no estudo. Estas técnicas, determinam que os resultados da análise sejam vistos como tendências do comportamento do sistema e não como um retrato fiel ou prognóstico dele. 


\section{CAPÍTULO 3}

\section{Modelagem e Simulação}

\subsection{Introdução}

O objetivo deste capítulo é apresentar como a modelagem e a simulação podem ser aplicadas à resolução de problemas de sistemas computacionais, desde a sua concepção até a fase relativa a seu uso [SOA92]. Assim, serão abordados mais especificamente os aspectos referentes às técnicas de modelagem, em particular, os modelos para simulação introduzidos no capítulo anterior.

As técnicas de modelagem, envolvem a construção e análise de modelos representativos do sistema a ser estudado, visando a obtenção de informações sobre o comportamento do sistema real que possam ser usadas na resolução dos problemas apresentados por eles [ORL95].

O modelo representativo do sistema consiste em uma visão particular do mesmo, determinada pelo problema que se deseja estudar, pela experiência do modelador, pelo nível de detalhes requeridos, pelo tipo de avaliação a ser feita, etc. Assim, um mesmo sistema pode ter diversos modelos que o representa.

Outro fator que influencia a construção de modelos para um sistema é o número de simplificações e suposições que se tornam necessárias para diminuir sua complexidade e até mesmo para que o modelo possa ser solucionado. Estas simplificações e suposições devem ser devidamente documentadas a fim de que possam ser feitas inferências cautelosas acerca das tendências do comportamento do sistema [ORL95].

\subsection{Definições}

Esta seção foi elaborada com o intuito de dar uma definição informal dos termos que serão usados com bastante freqüência ao longo deste texto.

O objetivo primordial deste trabalho é a simulação de sistemas, ou mais especificamente, a análise dos resultados de uma simulação. Assim, os sistemas podem ser encarados como uma coleção de objetos, entre os quais pode-se definir ou encontrar alguma relação de interesse para o estudo. Os sistemas de interesse neste trabalho, são os computacionais, onde os objetos que se interrelacionam podem ter as mais diversas conotações, por exemplo, usuários, recursos de hardware, etc. Estes sistemas, para que sejam estudados por meio de simulação ou de outra técnica devem ser modelados, caso contrário, medidas diretas deverão ser efetuadas. Assim, um modelo é criado para o sistema, que nada mais é do que uma descrição do mesmo. Esta descrição pode ser vista como uma abstração do sistema, devendo englobar apenas seus aspectos essenciais. Existem muitos modelos para um mesmo sistema, dependendo do enfoque, do problema, da visāo e experiência do modelador, etc.

Uma vez criado um modelo que represente o sistema adequadamente, o próximo passo a ser considerado é a simulação do sistema. Esta, consiste de 
experimentaçōes do modelo feitas através de um computador, modelo este, descrito de forma compreensível à máquina em que será executado.

É importante salientar que o modelo deve ser construído, não exclusivamente para simulação, mas também para uso em técnicas analíticas (até mesmo em conjunto com simulação para validação). Neste caso, tem-se os modelos analíticos, os quais são constituídos por equações matemáticas representativas do sistema, cuja solução, caso existente, reproduzirá o comportamento do sistema, muitas vezes de maneira muito precisa. Os modelos para simulação são aqueles constituídos por uma estrutura matemática/lógica cuja experimentação produz conclusões sobre o sistema [SOA92].

Ao se construir um modelo para simulação é, preliminarmente, necessário abstrair do sistema real todos os componentes (e suas interaçōes) julgadas relevantes ao problema em questão [MIT92]. Estes componentes são conhecidos como entidades. Associado a cada entidade pode existir ou não atributos, os quais correspondem a valores que descrevem o seu estado, que pode variar ou não com o tempo. O conjunto de todos os atributos num instante $t$ define o estado do sistema. As mudanças que ocorrem nestes estados sāo denominadas eventos, e os instantes de ocorrência, os tempos de eventos.

Um modelo de mudança discreta representa um sistema que é considerado somente em instantes selecionados no tempo e somente nestes instantes é que são observadas mudanças de estado. Ao contrário, um modelo de mudanca contínua representa um sistema em que as mudanças de estado ocorrem continuamente com o tempo. Assim, para cada instante $t$, dentro de um intervalo considerado, está associada uma mudança de estado, ou seja, a ocorrência de um evento. Os modelos considerados neste trabalho são os de mudança discreta.

\subsection{Formulação de Modelos}

Segundo Mitrani [MIT92], modelar um sistema é substituí-lo por algo mais simples ou mais fácil de estudar e que seja equivalente ao sistema original em todos os aspectos importantes. Considerando esta definição, é fácil perceber o caráter subjetivo dos modelos, em cuja construção está refletida a experiência do modelador, o qual apresenta uma visão particular do sistema. Assim, um modelo pode ser definido como uma abstração do sistema, no qual apenas seus aspectos relevantes estão representados.

Não existem regras formais para a formulação de modelos [MAC87], porém, para que isto possa ser feito, deve haver antes um completo entendimento do sistema a ser modelado, através da determinação de seus elementos e de suas relações de interesse [SHI75].

As principais questões pertinentes ao desenvolvimento do modelo envolvem o nível de abstração do sistema que se deseja modelar, quais as características do sistema que deverão ser incluídas no modelo e quais os parâmetros de entrada/saída que serão necessários [FER92], de modo a assegurar que o modelo seja uma representação válida do sistema real.

Se o sistema real interage de alguma forma com o mundo extemo, esta interação deve ser refletida no modelo [MIT92]. O modelo equivalente deve estar 
sujeito aos mesmos estímulos externos que o sistema real, produzindo saídas que serão interpretadas como a reação do sistema aos estímulos, conforme representado na figura 3.1.

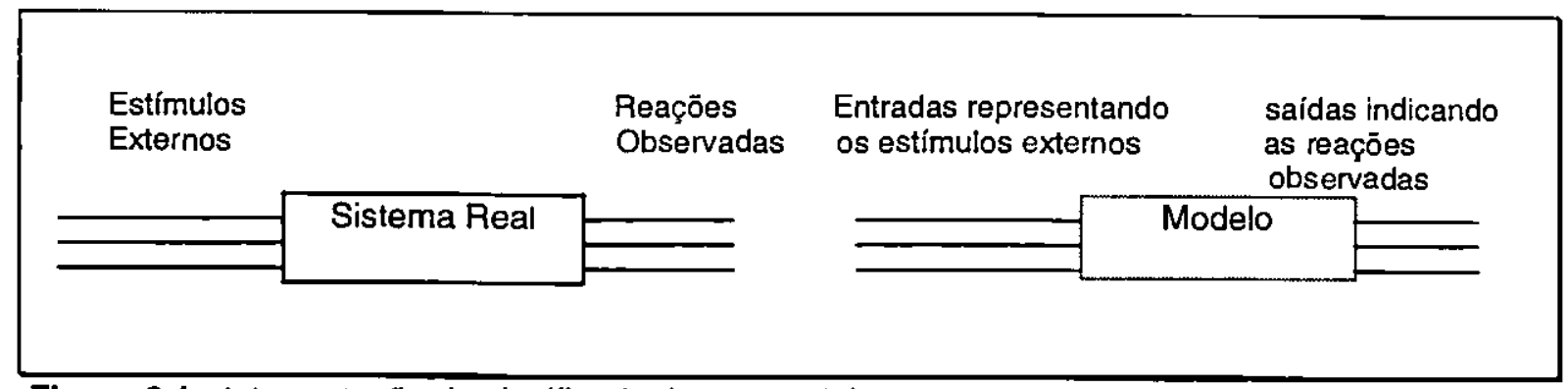

Figura 3.1: Interpretaçäo do significado de um modelo

Segundo Shimizu [SHI75], um modelo deve ser:

- suficientemente simples para permitir sua manipulação e entendimento;

- representativo do sistema dentro de uma precisão desejada;

- suficientemente complexo para permitir extrapolação de conclusões.

Para a análise de desempenho é necessária a formulação de um modelo que capture as características essenciais do sistema que exercem influência no seu desempenho [ORL95]. A complexidade da solução de um modelo depende da complexidade do sistema a ser estudado e do nível de detalhamento considerado.

Simplificaçōes e suposiçōes efetuadas no desenvolvimento de um modelo tendem a degenerá-lo, tomando-o pouco representativo. Para isso, é necessária a validação de todas as etapas do desenvolvimento da simulação para garantir que os resultados obtidos refletem as tendências do comportamento do sistema em estudo [ORL95].

A modelagem de sistemas é um processo que apresenta bastante flexibilidade a um custo relativamente baixo. O termo "relativamente" significa que depende do grau de precisão desejado [ORL95].

Conforme já mencionado, não existem regras para a formulação de um modelo, mas é de se esperar que um modelo sofra vários refinamentos até se concluir que ele realmente possa representar o sistema. A figura 3.2 ilustra este processo [SHI75].

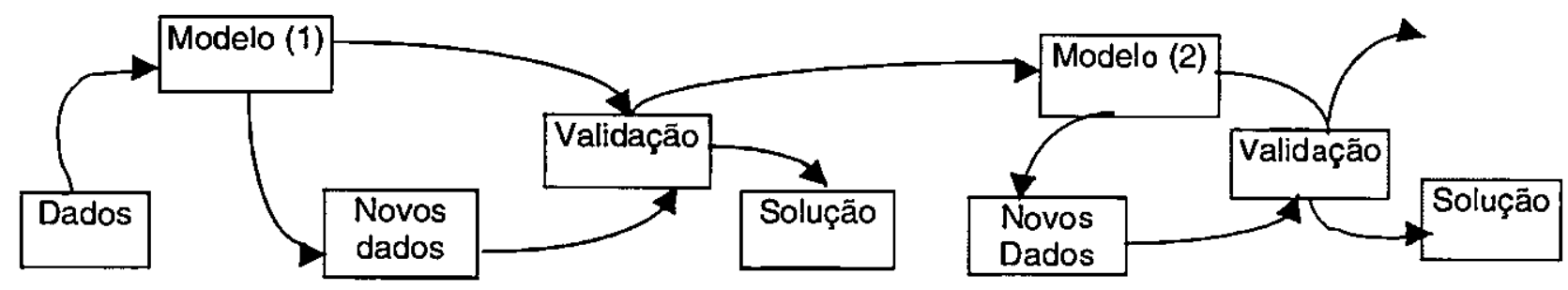

Figura 3.2: Refinamento do Modelo 


\subsection{Simulação}

Conforme já discutido nas seções anteriores, a simulação permite a obtenção de conclusões acerca de um sistema real através de um modelo que o represente [SHI75]. Estes modelos podem conservar ou não todas as características físicas e lógicas do sistema. Quando um modelo conserva as características físicas do sistema, a simulação resultante é denominada simulação física. É o caso das experiências de laboratório, mapas, protótipos e aparelhos de treinamento. Quando, porém, apenas as características lógicas do sistema são conservadas no modelo, tem-se uma simulação simbólica. Neste caso, tem-se os problemas determinísticos, estocásticos, problemas de economia, engenharia, análise de desempenho de sistemas computacionais, etc. Este é o tipo de simulação considerado neste trabalho.

Também já foi mencionado anteriormente que a simulação é um processo numérico e, portanto, pode ser determinístico ou estocástico [MIT92], conforme a natureza de seus dados de entrada [ORL95, GRO85]:

- Simulação Determinística: envolve problemas, para os quais os parâmetros de entrada são constantes no tempo, não sendo necessária nenhuma distribuição de probabilidades para descrevê-los.

- Simulação Estocástica: é aquela em que os dados de entrada são gerados aleatoriamente a partir de uma distribuição de probabilidades específica.

Um modelo que considera apenas as mudanças de estado do sistema que ocorrem em pontos isolados no tempo é denominado um modelo discreto e o exercício deste modelo, Simulação Discreta. Analogamente, um modelo que represente as mudanças de estado do sistema a cada instante do tempo, é denominado um modelo contínuo e o seu exercício, Simulação Contínua. Estes dois tipos de simulação serão caracterizados a seguir.

\subsubsection{SImulação Discreta}

$\mathrm{Na}$ simulação discreta, os estados do sistema, definidos em termos de valores numéricos associados aos atributos das entidades, só podem mudar em pontos isolados do tempo, os tempos de evento [SOA92]. Os modelos construídos para este fim, reproduzem as atividades das entidades através da definição dos estados do sistema e das atividades que modificam estes estados. Isto pode ser organizado segundo a descrição dos eventos, a descrição das atividades e a descrição dos processos, como será detalhado nas próximas seções.

\subsubsection{Organização da Simulação}

O comportamento dinâmico de um sistema é descrito por meio das seguintes entidades [MAC87]: 
- atividades: é a menor unidade de trabalho dentro de um sistema, tendo sempre um tempo associado a ela. É sempre iniciada e finalizada pela ocorrência de um evento. São as atividades que determinam a ocorrência dos eventos, e portanto, as mudanças de estado no sistema, sendo o fim de uma atividade, um evento.

- evento: é uma mudança de estado de qualquer entidade do sistema.

- processo: é um conjunto de atividades logicamente relacionadas, dependendo do nível de visão do sistema. Por exemplo, pode-se considerar a execução de um programa como um processo e as operações de entrada/saída como atividades. Mas, num outro nivel de detalhamento, pode-se considerar as operações de entrada/saída como um processo constituído de atividades, tais como: posicionamento, latência, transferência, etc., [SAN94a]. Os eventos que terminam uma atividade são locais aos processos aos quais a atividade pertence [MAC87].

Dessa forma, a simulação de um sistema pode ser vista através de vários enfoques [MIT92, SOA92, ORL95]:

- Simulação Orientada à atividade: baseia-se na descrição das atividades que ocorrem no sistema e das condições determinantes do início e término delas. Não existe escalonamento de eventos e a cada avanço do tempo simulado cada uma das atividades são verificadas, para determinar se alguma delas deve ser executada.

- Simulação Orientada a eventos: neste tipo de simulação, tem-se uma visão global de tudo o que ocorre no sistema, pois, trata-se da manipulação explícita dos eventos. Os eventos são escalonados conforme o seu tempo de ocorrência. Para isso, faz-se uso de uma lista de eventos. A cada ocorrência de um evento (cabeça da lista), uma rotina apropriada é executada.

- Simulação Orientada a Processos: este tipo de simulação visa agrupar os eventos relacionados de forma a representar o comportamento do sistema através de um conjunto de processos. Estes, são escalonados em uma lista (semelhante à lista de eventos futuros) conforme o tempo de ocorrência dos eventos e a cada avanço do tempo de simulação, as ações do processo na cabeça da lista são executadas. Conforme a ocorrência dos eventos, vários processos podem ser simultaneamente ativados e executados concorrentemente. As linguagens de simulação que seguem esta abordagem são modulares e bastante simples.

\subsubsection{Fases da Simulação}

Esta seção trata das etapas envolvidas no desenvolvimento e utilização de um modelo de simulação. O processo de simulação é dividido em três fases: desenvolvimento, testes e análise. Cada fase é constituída por vários passos. 0 passo mais importante em todo o processo é, sem dúvida, abstrair as 
características significativas do sistema em um modelo. $O$ grau de sucesso a ser obtido nesta tarefa, depende, em grande parte, da experiencia do modelador. Para os modeladores com pouca experiência, é importante iniciar simulando modelos simples, preferivelmente, que tenham solução analítica conhecida [MAC87].

É importante destacar também, que entre os passos, normalmente, há muitas iteraçōes de partes do processo. Eles podem não ser seguidos seqüencialmente e unidirecionalmente como são descritos [MAC87]. A figura 3.3 ilustra estas fases.

12) Fase de Desenvolvimento: Compōe-se das cinco etapas abaixo:

- Descrição do Sistema: consiste em definir exatamente o que se pretende com a simulação, de uma maneira clara e objetiva. Para tal, o modelador deve entender o funcionamento do sistema e de suas operações sob o ponto de vista do desempenho [MAC87]. É necessário, então, que o modelador passe por um estágio de aprendizagem sobre o sistema como um todo e principalmente sobre a parte que será estudada de forma a evitar que equívocos graves (na maioria das vezes, causados por falhas de comunicação) tomem a análise de resultados, um desperdício de tempo. O conhecimento adquirido pelo modelador é uma abstração do sistema (com considerações implícitas e explícitas) e desta forma deve constituir a base de uma descrição do sistema, a qual deve ser devidamente organizada e documentada. $O$ tempo gasto nesta tarefa é mais que compensado pela quantidade de erros eliminados.

- Formulação do Modelo: uma vez concluída a descrição do sistema, as características essenciais determinantes de seu desempenho são abstraídas num modelo. Duas abordagens podem ser empregadas para tal: as técnicas de síntese, constituindo uma representação em alto nível do sistema que combina ou ignora alguns de seus elementos ou atividades, ou as técnicas de decomposição, através do detalhamento sucessivo de suas atividades, sendo ideal para sistemas de grande porte. O modelo normalmente é descrito graficamente em pseudocódigo, definindo os componentes, os recursos, as variáveis descritivas e as interações que constituem o sistema. Uma das principais questōes nesta etapa é decidir se um componente particular deve ser ou não considerado como parte do modelo ou como parte do ambiente externo, devendo ser representado como entrada do modelo. Na maioria das vezes, $80 \%$ do comportamento de um sistema pode ser explicado pela ação de apenas $20 \%$ de seus componentes [PEG91]. O difícil é saber quais são estes componentes. Fica a cargo do modelador selecionar o que é importante para a análise, diminuindo a complexidade do modelo e viabilizando sua solução.

- Coleta de Dados: a partir do momento em que o modelo está pronto, já possível saber quais dados serão necessários, ou seja, os parâmetros do modelo. um único valor fixo ou em termos de uma distribuição de probabilidades e podem ser de dois tipos: parâmetros da carga de trabalho, 
como por exemplo, o tempo entre chegadas, tempo de execução, requerimentos de armazenamento, tipos e tamanho de registros, etc., e parâmetros do sistema, como o tempo de ciclo da memória ou das outras operações, sendo muitas vezes função dos anteriores. No caso de sistemas existentes, podem ser obtidos diretamente, por meio de instrumentação de hardware ou de software (já visto anteriormente) ou indiretamente, através das distribuições de probabilidades de seus valores. No caso de sistemas inexistentes, estes parâmetros deverão ser estimados. Os parâmetros que determinam a carga de trabalho do sistema são os mais difíceis de serem obtidos, pois a tarefa de se caracterizar a carga de trabalho de um sistema é complexa e esta complexidade tende a aumentar conforme aumenta 0 número de detalhes a serem considerados. Esta tarefa, porém, reflete a confiança que se pode ter nos resultados da simulação devido à intrínseca dependência existente entre a carga de trabalho de um sistema e seu desempenho [MAC87, KOB81].

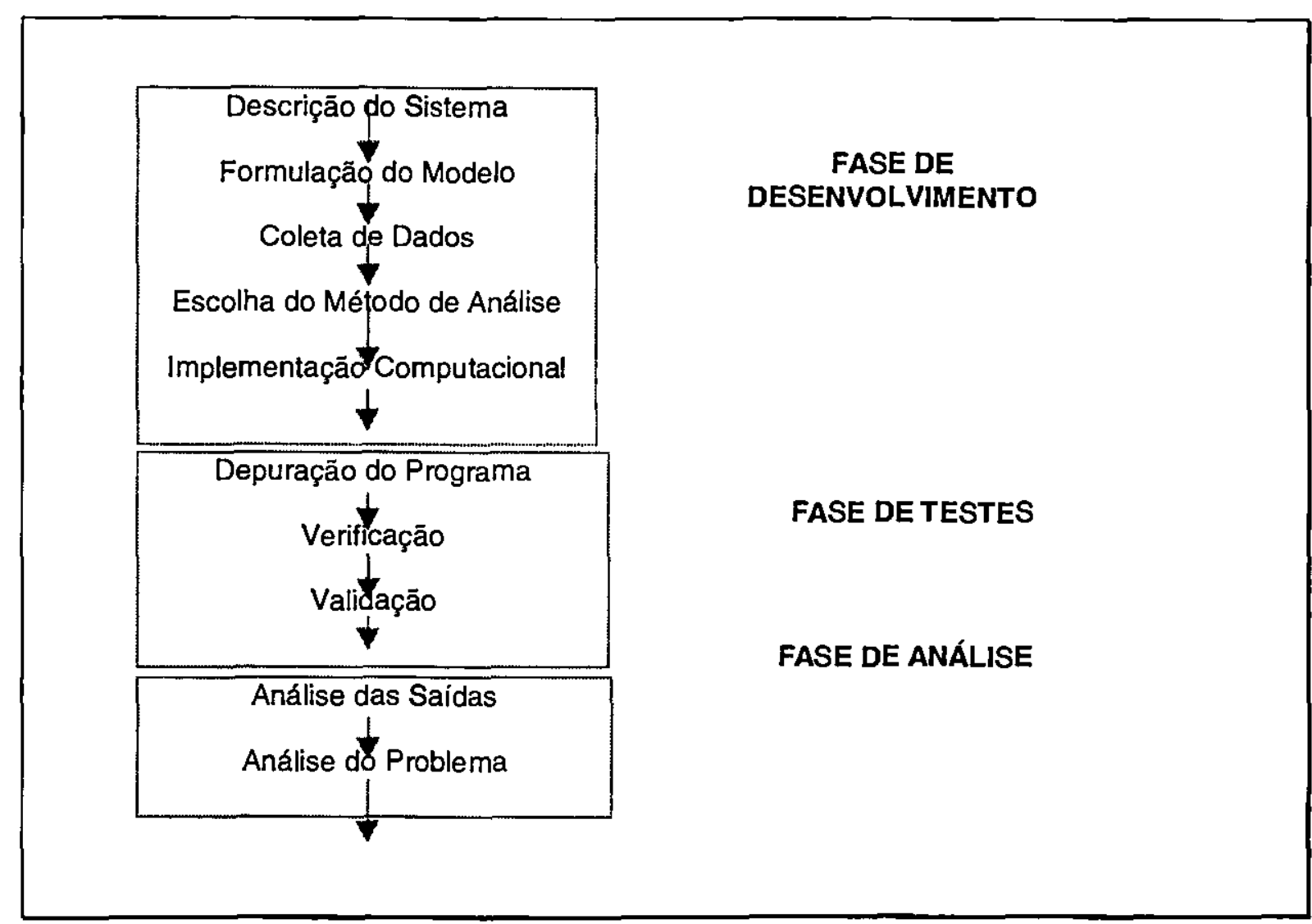

Figura 3.3: Fases de uma simulação

- Escolha do método de análise: nesta fase, o método de análise a ser aplicado sobre o modelo pronto e sobre os dados, será escolhido: métodos analíticos ou simulação. Esta escolha depende das ferramentas disponíveis e da habilidade do modelador. Os métodos analíticos são preferíveis devido à sua eficiência e exatidão de seus resultados. Mas, no entanto, o esforço despendido em sua solução (proporcionado pela complexidade inerente ao problema), pode inviabilizar sua utilização. Neste caso, faz-se uso da simulação. Sempre que necessário, aconselha-se a utilização dos dois 
métodos e a comparação dos resultados obtidos. Esta técnica permite a validaçāo dos resultados.

- Implementação Computacional: uma vez tendo optado pela simulação, resta agora transcrever o modelo criado num programa de computador. Antes, porém, deve-se adaptar o modelo segundo o enfoque dado pela linguagem adotada: atividades, eventos ou processos. É a primeira vez em todo o processo que a visão da linguagem de programação é imposta sobre o modelo [MAC87]. Feito isso, o modelo deverá ser transformado num programa. A seguir, é necessário atribuir valores aos parâmetros, ou seja, definir quais parâmetros devem receber valor em tempo de execução e quais devem receber valor em tempo de compilação. A escolha da linguagem a ser utilizada deve levar em conta diversos fatores, entre os quais, suas restrições, a complexidade do modelo, o tempo necessário para o processamento, o custo da execução, a facilidade de programação, a flexibilidade e a portabilidade [ORL95].

2a) Fase de Testes: Esta fase, tem por objetivo garantir que o programa de simulação faz o que o programador, o modelador e 0 usuário esperam dele [PEG91, SAR84]. Para isso, sāo definidas três etapas:

- Depuração: consiste em averiguar se o programa de simulação executa sem erros e se seus resultados parecem razoáveis. Para tanto, diversas ferramentas usuais em programação podem ser utilizadas: diagnósticos de erros, rastreadores, dumps e relatórios [MAC87].

- Verificação: consiste em verificar se a lógica do programa executado representa corretamente o modelo [PEG91], ou, nas palavras de MacDougall [MAC87], se o programa é uma implementação válida do modelo. A maneira mais comum de se fazer isso é comparando judiciosamente o modelo com o programa, o que naturaimente é bastante simples para modelos pequenos e mais complexo para modelos mais elaborados. Bastante comum (e desejável) é a comparação dos resultados do programa com os resultados teóricos obtidos por meio de métodos analíticos. Para facilitar esta fase, é sempre útil construir programas simples e de fácil entendimento, bem estruturados e documentados.

- Validaçāo: segundo MacDougall [MAC87], validação é a tarefa que demonstra que o modelo é uma representação razoável do sistema real, reproduzindo satisfatoriamente seu comportamento para análise. Trata-se de um processo iterativo, pois, se a comparação entre o modelo e o sistema produzir resultados inadequados, a formulação de um novo modelo deve ser feita. Quando se deseja validar modelos de sistemas já existentes, normaimente tem-se em mente verificar como o sistema se comportará frente a um determinado conjunto de mudanças. Neste caso, ao se validar o modelo, obtendo medidas do sistema real e comparando-as com os resultados da simulaçāo, é possivel prever qual comportamento o sistema real apresentará após efetivadas as mudanças. Para sistemas inexistentes, normalmente deseja-se estimar o 
desempenho do projeto antes da construção do sistema ou mesmo comparar projetos altemativos. Neste caso, uma vez que a comparação direta é impossível, o meio mais primitivo de se efetuar a validação é através da revisão do modelo. Além disso, os resultados podem ser comparados com valores teóricos conhecidos [ORL95]. É importante ressaltar que é muito difícil obter testes de validação absolutamente conclusivos [KOB81]. Na prática, as etapas de verificaçāo e validação são realizadas em conjunto, pois, se as medidas do sistema e os resultados do modelo são significativamente próximos, então, o programa de simulação é tido como uma representação válida do modelo e conseqüentemente do sistema real.

$\left.3^{a}\right)$ Fase de Análise: nesta fase, os resultados obtidos da simulação serão verificados com o intuito de se determinar se eles são satisfatórios e suficientes para que se possa fazer inferências sobre o desempenho do sistema real [BER94, PEG91].

E muito fácil tirar conclusōes erradas a partir dos resultados de uma simulação. Isto, porém, nem sempre se deve a erros de modelagem ou programação, mas sim, a interpretações enganosas dos resultados produzidos [MIT92]. Muitos acham que a animação gráfica de um modelo é suficiente para a análise dos resultado, servindo aos mesmos propósitos. Apesar de útil, a animação gráfica não pode substituir a análise dos resultados, não constituindo para isso, um meio suficientemente digno de crédito [PEG91].

Nesta fase, duas etapas podem ser definidas:

- Análise das Saídas: são métodos baseados em técnicas estatísticas que permitem a obtenção de uma estimativa precisa de uma medida de desempenho de um modelo, através do cálculo de um intervalo de confiança para a média de uma variável de saída [SAN94a]. Isto permite responder a muitas perguntas que surgem nesta fase, tais como:

- quais informaçōes devem ser obtidas?

- por quanto tempo um programa de simulação deve ser executado?

- qual a confiança que podemos ter nos resultados obtidos?

Este, é o tema central deste trabalho, visto com detalhes no capítulo 5.

- Análise do problema: uma vez feita a análise dos resultados de uma simulação, pode ser desejável analisá-los em conjunto com outros resultados, sejam eles, obtidos do mesmo sistema, a partir de outras variáveis de interesse ou de outros sistemas. Para isso, existem diversos métodos, como os de critérios múltiplos e inferência simultânea, que visam solucionar este problema [KLE87, MAC87]. 


\subsubsection{Vantagens e Desvantagens da Simulação}

Ao se decidir usar ou não a simulação, deve-se levar em conta suas vantagens e desvantagens, algumas das quais, estão relacionadas a seguir [SAN94, PEG91]:

\section{Vantagens:}

- permite que sistemas bastante complexos possam ser simulados. Muitas vezes, é o único meio de analisar o sistema;

- permite que novas situações sejam avaliadas para sistemas já existentes, como por exemplo, novas políticas, novos procedimentos operacionais, etc., sem que a operação normal do sistema seja prejudicada;

- permite a escolha entre sistemas alternativos;

- permite que seja mantido um controle maior sobre as condições do experimento em relação à experimentação direta;

- permite representar um período de tempo relativamente longo (tempo expandido) para o sistema;

- permite uma maior credibilidade para os resultados obtidos, pois um modelo de simulação é mais fácil de ser compreendido e justificado que um modelo analítico, podendo seu comportamento ser facilmente comparado ao do sistema real, requerendo menos suposições e simplificações que os mode-los analíticos, capturando mais caracteristicas verdadeiras do sistema real;

- permite que novos equipamentos e programas possam ser avaliados quanto ao seu desempenho antes de serem adquiridos.

\section{Desvantagens:}

- resultados efetivamente representativos de uma simulação requerem habilidade e experiência na construção de bons modelos;

- uma vez obtidos os resultados, a dificuldade agora está em irterpretá-los. Um volume grande de dados não é diretamente proporcional à confiança que se pode ter neles;

- a análise dos resultados costuma ser uma tarefa cara e demorada. Muitas vezes, uma análise adequada pode não ser possível devido à escassez de tempo e de recursos. Neste caso, uma análise rápida (e duvidosa) é adotada;

- devido ao caráter aleatório da simulação e do comportamento do sistema real, cada rodada de simulação produz apenas estimativas para as variáveis de interesse, para um determinado conjunto de parâmetros de entrada. Assim, são necessárias várias rodadas de simulação independentes para um mesmo conjunto de parâmetros de entrada.

\subsubsection{Simulação Contínua}

A simulação contínua é feita através de modelos que representam o sistema por meio de equações diferenciais, caracterizando a mudança contínua das variáveis ao longo do tempo [ORL95]. 
Este tipo de simulação traduz o comportamento do sistema durante a fase transiente e todas as perturbaçōes que ele sofre ao longo do tempo. Este tipo de análise de comportamento é muito útil em aplicações biomédicas e fenômenos físicos [ROT95].

Segundo Soares [SOA92], nas décadas de 50 e 60 , os computadores analógicos eram empregados em simulações contínuas. A dinâmica do sistema era representada através de componentes elétricos, como resistores, capacitores e amplificadores, cuja qualidade limitava a precisão dos resultados da simulação. Atualmente, são empregados computadores analógicos, digitais e híbridos em simulação contínua.

É importante destacar que os programas que executam os modelos de simulação contínua são aplicações de integração numérica, pois os computadores operam somente com quantidades discretas. Assim, as mudanças não podem realmente ocorrer continuamente em uma simulação contínua [PID92]. Este fato tem levado muitos fabricantes de software a concordar que nāo existe uma separação real entre simulação discreta e contínua. Assim, muitos softwares atuais permitem ao usuário programar modelos discretos, contínuos ou híbridos sem distinção. GASP IV segue esta abordagem.

Exemplos de linguagens próprias para simulação contínua:

- ACSL (Advanced Continuous Simulation Language): permite ao usuário desenvolver o código do modelo a partir de diagramas de blocos, equações matemáticas e declarações do FORTRAN convencional. Consiste de um conjunto de operadores aritméticos, funções padronizadas e de um conjunto especial de declarações ACSL. As especificações fomecidas pelo usuário são de dois tipos: um definindo o modelo e outro exercitando-o.

- CSMP: (Continuous System Modeling Program): o programa é construído através de três tipos de declaração: declarações estruturais, que definem o modelo, declarações de dados, os quais atribuem valores aos parâmetros, constantes, etc., e declarações de controle.

\subsection{Modelos de Redes de Filas}

Redes de filas são estruturas utilizadas na construção de modelos constituindo-se de entidades denominadas centros de serviço e de usuários. Os centros de serviço são formados pelos servidores (ou recursos) os quais prestam serviço ao sistema e por uma área de espera, denominada fila, onde os usuários esperam sua vez de serem atendidos. Os usuários (ou clientes) são as entidades do sistema que requerem e utilizam os recursos. As filas são formadas sempre que há disputa pelos servidores.

Redes de filas são muito utilizadas na modelagem de sistemas computacionais para análise de desempenho, pois, nestes é comum a disputa pelos recursos (CPU, memória, rede), gerando tempos de espera. O nível de disputa está relacionado com a carga do sistema e é um fator decisivo no desempenho do sistema. A figura 3.4 apresenta um sistema de filas básico. 


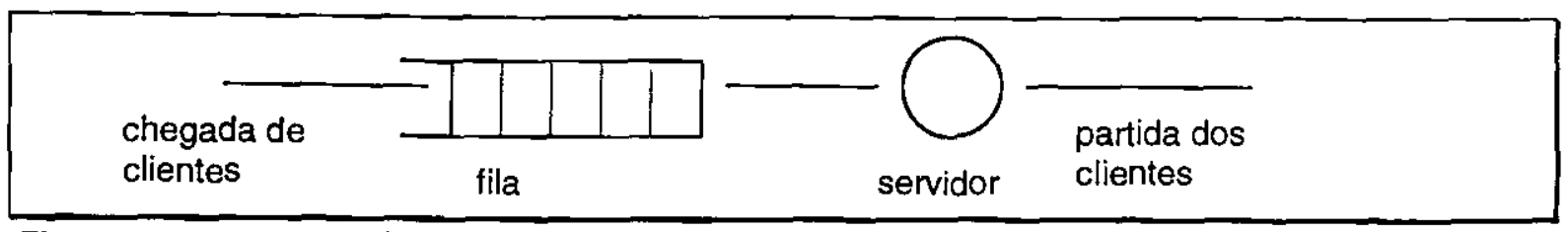

Figura 3.4: Estrutura básica de um sistema de filas

\subsubsection{Aspectos dos Sistemas de Filas}

Existem diversas variantes de um sistema de filas, conforme o número de filas e de servidores, resultando nos tipos ilustrados na figura 3.5.

O sistema de filas mais simples é aquele que contém uma fila e um servidor (1). O sistema (2) necessita de um algoritmo de escalonamento a fim de determinar qual usuário deverá ser atendido quando o servidor fica livre. No sistema (3), é o usuário quem deve determinar qual servidor deverá atender suas necessidades, no caso em que mais de um servidor estiver disponivel. No sistema (4), o mais complexo, deve existir tanto um algoritmo de escalonamento para determinar de qual fila será retirado o próximo usuário, como também deve existir uma política para selecionar o servidor desejado.

Os recursos de um sistema de filas podem ser classificados em ativos ou passivos. Recursos ativos são aqueles que prestam serviço. Por exemplo, a CPU de um computador. Os recursos passivos, ao contrário, não prestam serviço e são simplesmente alocados aos usuários. Como exemplo, pode-se citar a memória de um computador [SOA92].

Os sistemas de filas também podem ser classificados como sistemas abertos, fechados ou mistos. Num sistema aberto, os usuários entram e a qualquer momento podem abandoná-lo, isto é, o número de usuários dentro do sistema pode variar com o tempo. Num sistema fechado, o número de usuários permanece fixo, do ponto de vista do sistema. Mesmo que alguns usuários estejam saindo, outros estão chegando na mesma proporção, de modo a manter o número total de usuários constante. Os sistemas mistos, são constituídos de partes em que o sistema é aberto e de outras em que é fechado.

Num sistema de filas, quando um usuário deixa um centro de senviço, uma decisão deve ser tomada sobre para onde deverá ir em seguida, ou seja, para qual centro. A este tipo de decisão denomina-se decisão de roteamento. Uma rota pode ser vista como uma coleção de centros de serviço visitados. As decisões de roteamento podem ser baseadas no comprimento de uma determinada fila, tempo de serviço para aquele usuário, etc.

\subsubsection{Caracterização de um sistema de filas}

Quando se deseja construir um modelo baseado em redes de filas, várias características devem ser determinadas. São elas:

\subsubsection{O processo de chegada}

Define o padrão pelo qual os usuários chegam ao sistema. Pode ser determinístico ou estocástico. Quando determinístico, as chegadas ocorrem em 
intervalos de tempo regulares. O processo mais usual, por ser mais representativo da realidade, é o estocástico, em que os tempos entre as chegadas são determinados através de uma distribuição de probabilidades. Quando um processo de chegada não varia como o tempo, isto é, os valores dos parâmetros da distribuiçāo de probabilidades são independentes do tempo, é chamado de processo estacionário.

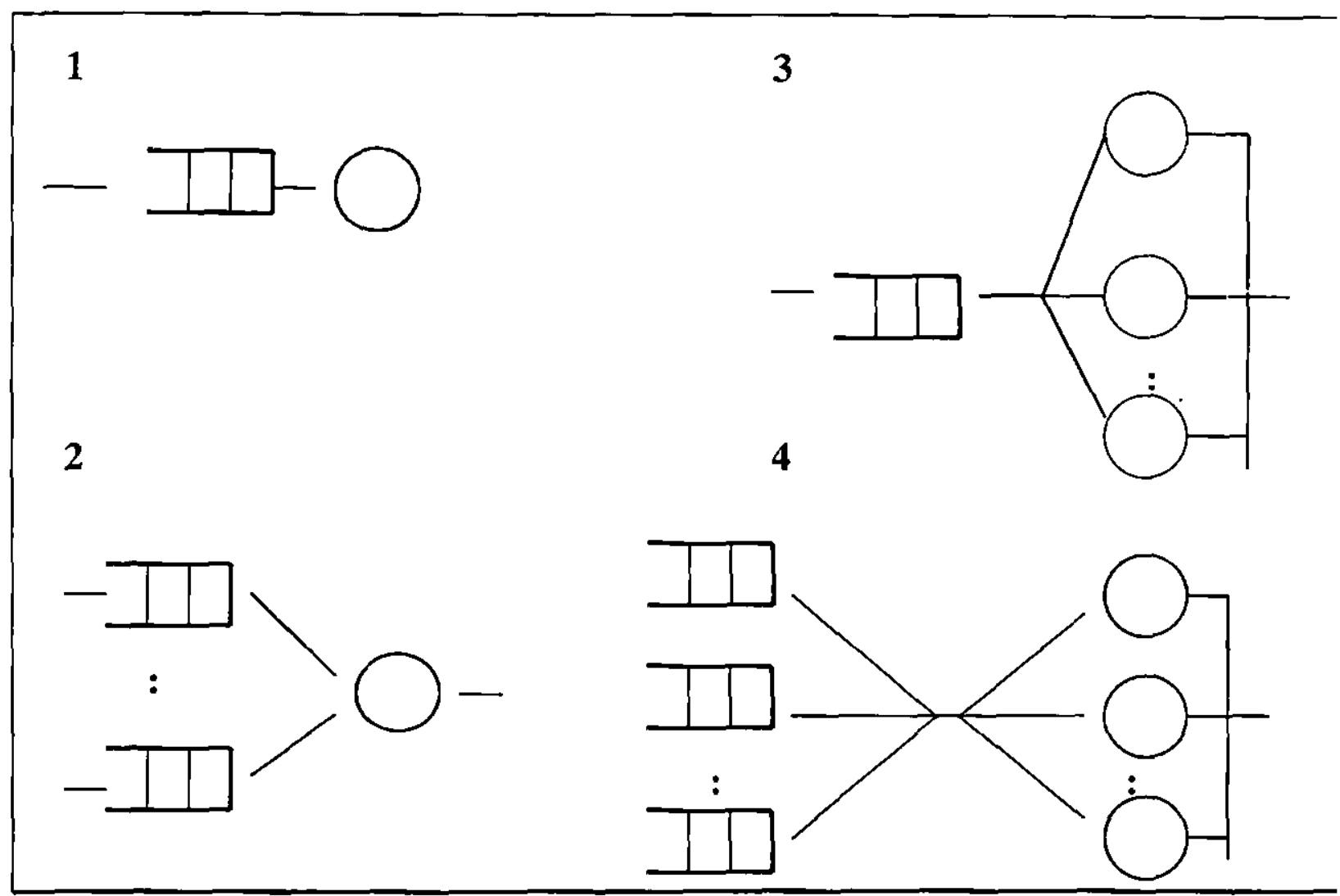

Figura 3.5: Sistemas de Filas

\subsubsection{O processo de serviço}

Define o padrão pelo qual o servidor executa o serviço para cada cliente. Por isso, trata-se de uma característica própria do servidor e é independente do processo de chegada.

Da mesma forma que o processo de chegada, pode ser determinístico ou aleatório. Pode ocorrer de o processo de serviço ser dependente do estado, por exemplo, se o servidor vê que a fila está muito grande ele pode trabalhar mais rápido ou ficar atrapalhado e demorar mais tempo.

A distribuição de probabilidades mais comum é a exponencial, onde o tempo de serviço para um determinado cliente independe do tempo gasto com o cliente anterior. Outras distribuições de probabilidade tais como, a k-erlang, a uniforme e a hiperexponencial, podem também ser consideradas dependendo do comportamento do sistema em questão [ORL95]. 


\subsubsection{Disciplina da Fila}

Define a forma pela qual os clientes serão atendidos. São várias:

- FCFS (First Come First Served):- os clientes são atendidos pela ordem de chegada;

- LCFS (Last Come First Served):- os clientes são atendidos pela ordem inversa à chegada;

- SIRO (Service In Random Order):- ordem aleatória de atendimento;

- PRI (Priority Service):- a cada cliente está associada uma prioridade de atendimento;

- RR (Round Robin):- cada cliente é atendido por um intervalo fixo de tempo. Se sua necessidade de serviço excede este intervalo, o cliente volta para o final da fila e aguarda novamente sua vez de ser atendido, até que o serviço seja concluído.

Numa fila com prioridade, duas situações podem ocorrer quando um cliente com menor prioridade está sendo atendido e um outro, com maior prioridade, chega ao sistema:

- prioridade preemptiva: o servidor interrompe imediatamente o serviço do cliente de menor prioridade, que retoma à fila e aguarda o servidor atender 0 cliente de maior prioridade;

- prioridade não preemptiva: o cliente de maior prioridade aguarda até o servidor concluir o serviço do cliente de menor prioridade, sendo atendido logo a seguir.

\subsubsection{Capacidade do Sistema}

Refere-se ao número máximo possível de clientes dentro do sistema, muitas vezes, decorrente de limitações físicas. Muitos sistemas não têm limite para este número e todo cliente que chega ao sistema pode aguardar por atendimento. Existem sistemas com capacidade nula, em que os clientes ao chegar, vêem que o servidor está ocupado e saem do sistema.

\subsubsection{Número de Servidores}

Pode variar de um até o infinito. O sistema com apenas um servidor é o mais simples, podendo atender a um único cliente por vez. Um sistema com $n$ servidores pode atender até $n$ clientes simultaneamente. Já em um sistema com infinitos servidores, para cada cliente que chega ao sistema, existe sempre um servidor disponivel para atendê-lo e por isso não ocorre a formação de filas.

\subsubsection{Notação para o Sistema de Filas}

Utiliza-se, em geral, a notação de Kendall [SAN94], da seguinte forma: 
Onde:
A: distribuição dos tempos entre as chegadas;
B: distribuiçāo dos tempos de serviço;
c: número de servidores;
K: capacidade do sistema;
m: tamanho da populaçāo;
Z: disciplina da fila.

$A$ e $B$ podem ter:
M: distribuiçāo exponencial;
Gl: tempo geral e independente;
G: tempo geral;
$\mathrm{H}_{\mathrm{k}}$ :distr. hiperexponencial de k-stágios;
$\mathbf{E}_{\mathbf{k}}$ : distribuiçāo Erlang-k;
D: distribuição determinística;
U: distribuição uniforme.

A notação abreviada $A / B / C$ assume que a capacidade do sistema é infinita (representado pela ausência do $K$ ), o tamanho da população é infinito (ausência do $m$ ) e que a fila segue a disciplina FCFS (ausência do $Z$ ).

Uma fila muito utilizada em simulação é a fila $M / M / 1$, onde:

- a distribuição dos tempos entre chegadas é exponencial de parâmetro $\lambda$;

- a distribuição dos tempos de serviço é exponencial de parâmetro $\mu$;

- existe um único servidor;

- o sistema tem capacidade infinita;

- o tamanho da população é infinito;

- os clientes são atendidos por ordem de chegada.

Ao aplicar um modelo de filas para análise de desempenho, pretende-se determinar medidas do tipo: número médio de clientes no sistema, número médio de clientes na fila, tempo médio de permanência do cliente no sistema e tempo médio de espera do cliente na fila.

\subsection{Números aleatórios}

Através da análise dos dados coletados em sistemas reais e que representam algumas características do sistema (tais como: tempo de serviço, tempo de chegada, etc.), observa-se que: nāo há como manter controle sobre os dados e que uma vez obtida uma seqüência de valores, não é possível reproduzila, pois trata-se de uma seqüência aleatória.

Ao fazer uma simulação, este comportamento aleatório deve ser reproduzido artificialmente. Portanto, devido à sua própria natureza, a simulaçāo estocástica requer um meio confiável para a geração de números aleatórios.

Existem vánios métodos para a geração de números aleatórios. Um deles, consiste na leitura de uma tabela especialmente construída para esta finalidade (como, por exemplo, a tabela da RAND Corp.). Tabelas deste tipo têm a nítida desvantagem de tornar o processo de simulação mais lento, uma vez que devese recorrer a dispositivos externos, onde a tabela está armazenada, cada vez que há necessidade de um número aleatório. Outro método, consiste na utilização de dispositivos físicos geradores de ruídos aleatórios, cuja medição de seus níveis gera números aleatórios. O problema com este método é que a mesma seqüência não pode ser gerada mais de uma vez. O método utilizado mais freqüentemente é o algorítmico, onde uma equação recursiva gera o i-ésimo 
número aleatório a partir do (i-1)ésimo número gerado. Este método, na realidade, não produz números verdadeiramente aleatórios, mas sim, números pseudo-aleatórios, pois a seqüência é produzida deterministicamente através de uma equação [SOA92, MIT92].

Para que os números pseudo-aleatórios possam ser usados em lugar dos verdadeiramente aleatórios, eles devem satisfazer às seguintes propriedades:

1. Os números devem ser distribuídos uniformemente no intervalo $[0,1]$.

2. Os números devem ser independentes, não existindo correlação na seqüência.

3. O ciclo ou período da geração deve ser bastante longo, de modo que, muitos números possam ser gerados antes que a seqüência seja repetida.

4. A seqüência de números aleatórios gerada deve poder ser reproduzida a partir de uma dada semente, de modo que, variando as sementes, seqüências diferentes sejam geradas.

5. O gerador deve ser rápido.

6. O espaço necessário para armazenar a geração deve ser mínimo.

O método congruencial linear ou método congruente é o mais utilizado para a geração de números aleatórios, satisfazendo às propriedades acima. As seguintes equações recursivas são utilizadas:

$$
\begin{array}{ll}
z_{i+1}=\left(a z_{i}+b\right)(\bmod c) & \text { onde: } \\
\text { e } r_{i+1}=\frac{z_{i+1}}{c} & i=0,1,2, \ldots \\
& z_{0} \text { é a semente } \\
& r_{i} \text { é o i-ésimo número pseudo-aleatório } \\
& c \geq 2 \text { e } a, b \text { e } z_{0} \in\{0,1, \ldots, c-1\} \\
& a, b \text { e } c \text { são constantes dependentes do computador }
\end{array}
$$

Nas próximas seçōes, serão apresentados exemplos de simulação que ilustram os conceitos discutidos neste capítulo.

\subsection{Exemplo de Simulação Manual de uma situação real}

O exemplo discutido nesta seção é apresentado em [PEG91] e considera a existência de uma única fila onde os clientes aguardam sua vez de serem atendidos por um caixa de supermercado. O tempo entre as chegadas dos clientes é uniformemente distribuído no intervalo de 1 a 10 minutos e o tempo de serviço dos clientes também é uniformemente distribuído entre 1 e 6 minutos. Pretende-se determinar o tempo total médio gasto pelos clientes (tempo na fila + tempo de atendimento) e a porcentagem de tempo que o caixa fica livre.

Um primeiro requisito para a simulação deste sistema é a obtenção de uma forma para gerar artificialmente os tempos de chegada para cada cliente, bem como seus tempos de serviço. Necessita-se também de um bom sistema de armazenamento para registrar tudo o que acontece. Uma maneira pela qual pode-se gerar os tempos entre as chegadas dos clientes é usar uma espécie de roleta cuja superfície esteja dividida em 10 partes iguais numeradas. Para gerar os tempos de serviço utiliza-se um dado.

O relógio de simulação deve estar inicialmente em 00:00hrs e então rodase a roleta para ver quantos minutos decorrerão até o primeiro cliente chegar ao caixa. Após a chegada do primeiro cliente, o dado é lançado para determinar o 
tempo de serviço (tempo que o cliente gastará no caixa). Continuando este processo para os clientes subseqüentes e registrando numa tabela os tempos de chegada, de início de serviço, de partida, bem como o tempo que o caixa permanece livre, para vinte clientes, tem-se a tabela da figura 3.6.

Como pode-se observar, foram utilizados dois dispositivos diferentes para a geração de variáveis aleatórias de forma a poder examinar algumas das características do sistema dependentes do tempo. Observando-se a simulação descrita fica claro que, à medida que o sistema se torna mais complicado ou tenha mais componentes, um computador deverá ser utilizado tanto para a geração variáveis aleatórias como para armazenar os dados obtidos.

\subsection{Exemplo de Simulação para Análise de Desempenho}

Este exemplo é apresentado por MacDougall, em [MAC87], e ilustra um modelo de redes de filas, representando um sistema computacional com uma CPU e quatro unidades de disco. Um número fixo de tarefas de duas classes diferentes é executado no sistema, alternando entre a CPU e as atividades de disco. Existem $n_{0}$ tarefas da classe 0 , as quais tem um tempo médio de execução de CPU de $10 \mathrm{~ms}$ e $n_{1}$ tarefas da classe 1, cujo tempo médio de execução de CPU é de $5 \mathrm{~ms}$. Os tempos de execução de CPU para ambas as classes são distribuídos exponencialmente (figura 3.7).

As requisições da CPU das tarefas da classe 1 têm prioridade preemptiva sobre as da classe 0 . Se uma tarefa da classe 1 requisita a CPU quando ela estiver sendo usada por uma tarefa da classe 0 , esta é preterida e enfileirada e a CPU é alocada para a tarefa da classe 1 que a requisitou. $A$ tarefa interrompida retoma sua execução quando não existirem mais tarefas da classe 1 requisitando a CPU.

As requisições de disco de ambas as classes são distribuídas aleatoriamente e uniformemente através dos quatro discos com o mesmo tempo médio de serviço de disco de $30 \mathrm{~ms}$. Supõe-se que os tempos de serviço de disco seguem uma distribuição de Erlang com um desvio padrão igual ao do tempo de senviço médio.

O objetivo desta simulação é estimar o tempo de ciclo de cada classe de tarefa. O tempo de ciclo é o intervalo entre duas requisições sucessivas da CPU e de uma tarefa. Conhecendo-se o tempo médio de ciclo de uma classe e o número médio de ciclos. que ela faz (número médio de requisições de disco) pode-se computar facilmente o tempo médio que uma tarefa gasta no sistema.

$\mathrm{Na}$ figura 3.8 está reproduzido o programa de simulação escrito em $\mathbf{s m p l}$ (uma extensão funcional para simulação baseada na linguagem C) [MAC87] que implementa o modelo exemplificado. Após sua compilação e execução, o programa apresenta o relatório reproduzido na figura 3.9. 


\begin{tabular}{|c|c|c|c|c|c|c|c|}
\hline C1iente & $\begin{array}{c}\text { tempo } \\
\text { entre } \\
\text { chegadas }\end{array}$ & $\begin{array}{c}\text { Tempo } \\
\text { de } \\
\text { serviço }\end{array}$ & $\begin{array}{c}\text { Instante } \\
\text { de } \\
\text { chegada }\end{array}$ & $\begin{array}{c}\text { Iníí do } \\
\text { serviço }\end{array}$ & $\begin{array}{c}\text { Término } \\
\text { do } \\
\text { serviço }\end{array}$ & $\begin{array}{c}\text { Tempo } \\
\text { gasto no } \\
\text { sistema }\end{array}$ & $\begin{array}{c}\text { Tempo } \\
\text { ivre }\end{array}$ \\
\hline 1 & - & 3 & $00: 00$ & $00: 00$ & $00: 03$ & 3 & 0 \\
\hline 2 & 6 & 1 & $00: 06$ & $00: 06$ & $00: 07$ & 1 & 3 \\
\hline 3 & 6 & 6 & $00: 12$ & $00: 12$ & $00: 18$ & 6 & 5 \\
\hline 4 & 4 & 4 & $00: 16$ & $00: 18$ & $00: 22$ & 6 & 0 \\
\hline 5 & 7 & 2 & $00: 23$ & $00: 23$ & $00: 25$ & 2 & 1 \\
\hline 6 & 1 & 4 & $00: 24$ & $00: 25$ & $00: 29$ & 5 & 0 \\
\hline 7 & 1 & 5 & $00: 25$ & $00: 29$ & $00: 34$ & 9 & 0 \\
\hline 8 & 9 & 4 & $00: 34$ & $00: 34$ & $00: 38$ & 4 & 0 \\
\hline 9 & 8 & 3 & $00: 42$ & $00: 42$ & $00: 45$ & 3 & 4 \\
\hline 10 & 9 & 1 & $00: 51$ & $00: 51$ & $00: 52$ & 1 & 6 \\
\hline 11 & 6 & 6 & $00: 57$ & $00: 57$ & $01: 03$ & 6 & 5 \\
\hline 12 & 5 & 4 & $01: 02$ & $01: 03$ & $01: 07$ & 5 & 0 \\
\hline 13 & 4 & 5 & $01: 06$ & $01: 07$ & $01: 12$ & 6 & 0 \\
\hline 14 & 8 & 1 & $01: 14$ & $01: 14$ & $01: 15$ & 1 & 2 \\
\hline 15 & 8 & 4 & $01: 22$ & $01: 22$ & $01: 26$ & 4 & 7 \\
\hline 16 & 7 & 2 & $01: 29$ & $01: 29$ & $01: 31$ & 2 & 3 \\
\hline 17 & 4 & 2 & $01: 33$ & $01: 33$ & $01: 35$ & 2 & 2 \\
\hline 18 & 2 & 6 & $01: 35$ & $01: 35$ & $01: 41$ & 6 & 0 \\
\hline 19 & 7 & 1 & $01: 42$ & $01: 42$ & $01: 43$ & 1 & 1 \\
\hline 20 & 9 & 4 & $01: 51$ & $01: 51$ & $01: 55$ & 4 & 8 \\
\hline & & & & & Totais: & 77 & 47 \\
\hline
\end{tabular}

Tempo médio no sistema: $77 / 20=3.85$ minutos $8 T e m p o$ que o servidor permanece 1 ivre: 418

Figura 3.6: Relatório produzido pela simulaçāo manual.

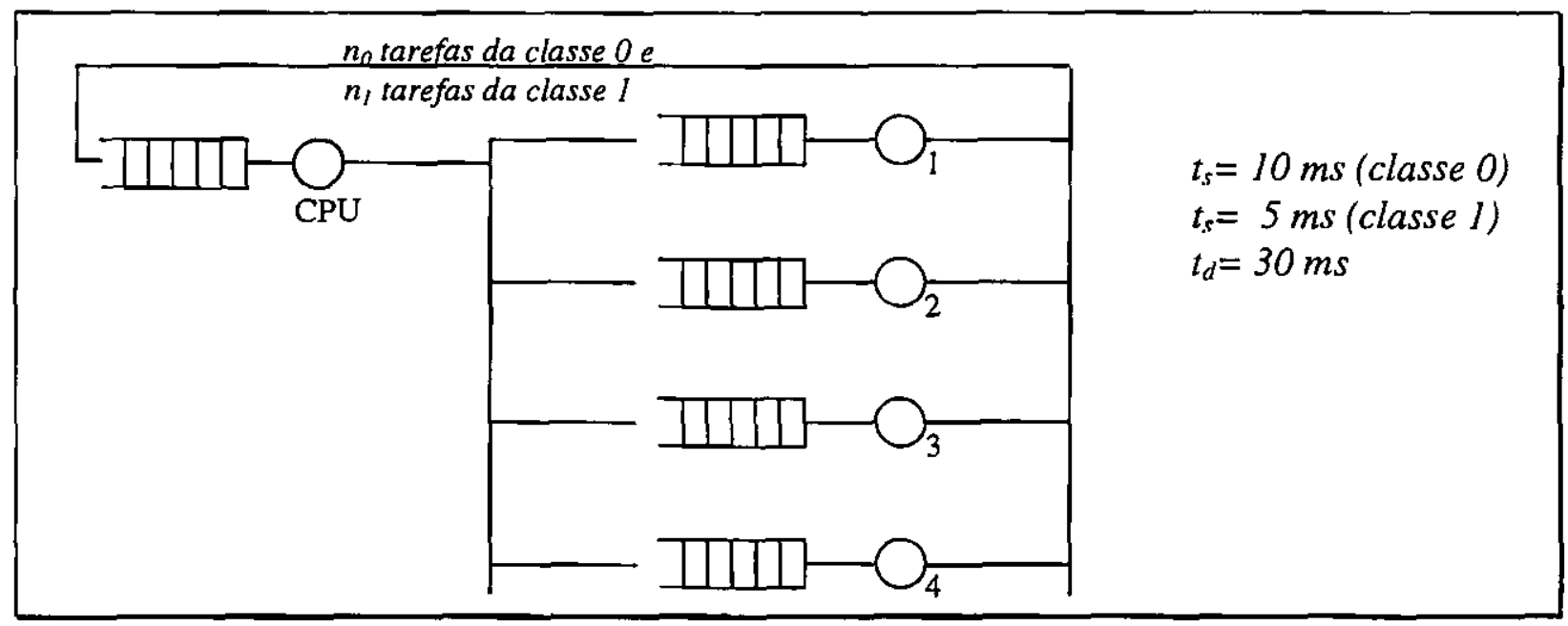

Figura 3.7: Representação do sistema de redes de filas do exemplo. 


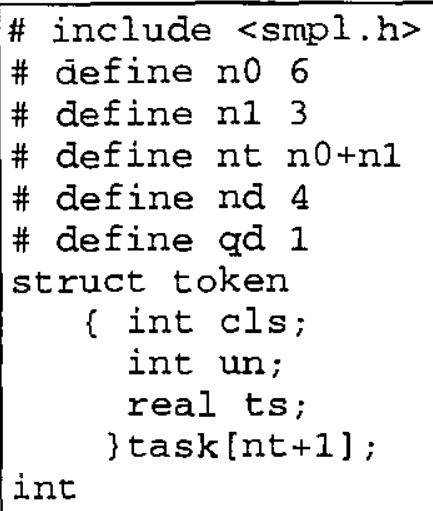

Figura 3.8: Programa de simulação em smpl para o modelo do exemplo . 
MODEL: modelo do servidor central

TIME : 96527.553

INTERVAL: 96527.553

$\begin{array}{lllllll} & & \text { MEAM BUSY } & \text { MEAN QUEUE } & \text { OPERATION } & \text { COUNT } & \\ \text { FACILITY UTIL. } & \text { PERIOD } & \text { LENGHT } & \text { RELEASE } & \text { PREEMPT } & \text { QUEUE } \\ \text { CPU } & 0.8151 & 6.202 & 1.286 & 12687 & 2682 & 7335 \\ \text { disk } & 0.7712 & 29.970 & 0.933 & 2484 & 0 & 1838 \\ \text { disk } & 0.7561 & 29.704 & 0.847 & 2457 & 0 & 1787 \\ \text { disk } & 0.7804 & 29.844 & 0.971 & 2524 & 0 & 1896 \\ \text { disk } & 0.7886 & 30.029 & 1.051 & 2535 & 0 & 1931\end{array}$

Figura 3.9: Relatório apresentado pelo programa do exemplo.

\subsection{Comentários Finais}

Com a evolução tecnológica alcançada pelos computadores atuais, a simulação tem se tornado uma ferramenta muito poderosa para análise do desempenho de sistemas computacionais e de outros sistemas em geral. Porém, independentemente de quão evoluída esteja a tecnologia empregada no processo de simulação, sua eficiência como método de análise vai sempre depender da representatividade do modelo construído. Este, por sua vez, deve refletir tudo o que é importante no sistema de maneira correta, bem como, as mudanças de estado que ocorrem no sistema conforme o tempo. Estas mudanças ao longo do tempo, determinam os dois tipos de simulação: a discreta e a contínua.

A simulação discreta, principal enfoque deste texto, é aquela em que as mudanças de estado podem ocorrer apenas em pontos isolados no tempo e pode ser organizada segundo os eventos, as atividades ou os processos. O processo de simulação envolve diversas fases: desenvolvimento, testes e análise, cada qual constituída de diversas sub-fases. Suas principais vantagens são a flexibilidade de aplicação, (independendo da complexidade do sistema modelado), a confiabilidade de resultados e a facilidade de uso. Por outro lado, a interpretação de seus resultados é um processo que exige habilidade e experiência, da mesma forma que a construção do modelo. Além disso, a análise dos resultados é uma tarefa cara e demorada.

A simulação contínua, pouco abordada neste trabalho, tem um vasto campo de aplicação na área biomédica e na análise de fenômenos físicos, preocupando-se com processos que variam continuamente com 0 tempo e empregando modelos baseados em equações matemáticas. Muitas linguagens atualmente estão orientadas à simulação contínua, mas esta diferenciação aos poucos parece estar perdendo a força, pois a maioria dos fabricantes de software da atualidade tendem a não classificar mais a simulação em sendo discreta ou contínua. 
O modelo de redes de filas é muito utilizado na análise de desempenho de sistemas computacionais devido ao interesse em analisar a disputa pelos recursos disponíveis no sistema. O modelo de redes de filas é um modelo bastante preciso que permite incorporar um número relativamente grande de detalhes do sistema real. No sentido de aplicá-lo em simulação, torna-se de grande valia o conhecimento das técnicas para a geração de números e amostras aleatórias, da mesma forma que a estimativa de parâmetros e de distribuições de probabilidades, as quais corresponderão aos dados de entrada da simulação.

Este capítulo apresentou dois exemplos finais a fim de ilustrar o seu contexto. O primeiro, simulação manual, utiliza aspectos intuitivos e amplamente conhecidos do quotidiano e o segundo, já é mais específico para aplicação da teoria das filas aos sistemas computacionais. 


\section{CAPÍTULO 4}

\section{Ferramentas para Simulação de Sistemas}

\subsection{Introdução}

Como foi visto nos capítulos anteriores, simular implica em reproduzir o comportamento de um sistema através da execução de um programa de computação. Para que isto possa ser feito, há a necessidade de se transcrever o modelo abstraído do sistema para um programa através de alguma linguagem de programação. A linguagem de programação escolhida, por sua vez, deve permitir a representação da estrutura estática e do comportamento dinâmico do sistema a ser modelado [SPO94].

Existem vários tipos de ferramentas utilizadas para simulação: linguagens de programação de propósito geral, linguagens de simulação, extensões funcionais ou pacotes de uso específico. A escolha entre elas pode ser feita levando-se em consideração a dificuldade em programar detalhes do ambiente da simulação, o tempo necessário para se aprender uma nova ferramenta, a adequabilidade, etc.

A tarefa de transcrever o modelo para um programa não é trivial, requerendo que o modelador tenha conhecimentos em três áreas distintas: simulação, programação e a área correspondente ao sistema estudado. Normalmente, os modeladores não são especialistas em programação, o que tomaa a simulação pouco atraente, apesar de muito útil.

$\mathrm{Na}$ busca de soluções para este problema, têm surgido os sistemas automáticos de simulação, nos quais o usuário deve apenas fornecer o modelo e seus parâmetros, sem ter que se preocupar com detalhes de implementação. Vários sistemas automáticos serão apresentados no decorrer deste capítulo.

É neste contexto que surge o ASiA, um ambiente de simulação automático desenvolvido pelo grupo de sistemas distribuídos do ICMSC-USP, o qual permite que o modelador descreva graficamente o modelo a ser simulado através de um editor gráfico e este o organiza de maneira que um gerador de aplicações possa automaticamente reproduzir o programa de simulação.

O ASiA será visto com maiores detalhes ao longo deste capítulo.

\subsection{Ambientes de Simulação}

Serão apresentadas a seguir, uma variedade de ambientes que o usuário dispōe para implementar seu programa de simulação. Também será mostrada a maneira pela qual cada ambiente considera a simulação, podendo ser orientada a atividade, a processo ou a evento. 


\subsubsection{Linguagens de uso geral}

De maneira geral, qualquer linguagem de programação pode ser utilizada na implementação de um programa de simulação. Desta forma, a familiaridade que o modelador tem com uma determinada linguagem de programação, é um ponto importante na sua escolha para a implementação do programa. Além desta vantagem (o modelador não precisa aprender uma nova linguagem para fazer uma simulação) existem outras: portabilidade, flexibilidade, etc. Quanto à portabilidade, o programa poderá ser executado em outros computadores (bastando ter o compilador), e quanto à flexibilidade (como é o modelador quem cria o programa, sem qualquer suporte da linguagem, ele poderá dar ao mesmo o enfoque de simulação desejado). Assim, o modelador pode desenvolver um ambiente orientado a eventos, processos ou atividades, dependendo da aplicação [SPO94].

Esta abordagem, porém, oferece uma desvantagem bastante significativa: - modelador tem que criar o programa e todas as estruturas necessárias a um ambiente de simulação, pois estas linguagens não dão suporte à mesma. Isto se transforma num obstáculo para os modeladores que não têm experiência com programação.

\subsubsection{Linguagens de Simulação}

Dada a grande utilidade da simulação, a existência de certas técnicas e processos comuns à maioria dos programas de simulação e a dificuldade encontrada em se utilizar linguagens de propósito geral na tarefa de programação, têm surgido muitas linguagens especialmente voltadas para esta finalidade, ou seja, as linguagens de simulação.

A principal vantagem do uso destas linguagens é que elas já possuem as estruturas necessárias ao ambiente de simulação, mantendo considerável flexibilidade em relação ao tipo do programa a ser implementado e auxiliando o modelador na tarefa de programar. Como desvantagem tem-se o fato de que como se trata de uma linguagem nova, o modelador tem que aprendê-la para poder utilizá-la.

As linguagens para simulação discreta podem ser classificadas segundo a organização procedural dos programas escritos através delas, impondo ao modelador uma visão orientada a eventos, processos ou atividades.

Linguagens orientadas a eventos: são aquelas, cujo programa de simulação é constituído por procedimentos, os quais são executados conforme a ocorrência dos eventos (tempo de evento). A tarefa do programador consiste em determinar os eventos que podem causar mudança no estado do sistema (representado por variáveis, por entidades do modelo e seus atributos, pela localização destas entidades no modelo, etc) e desenvolver a lógica associada a eles [SOA92]. O sistema é simulado pela execução da lógica em uma seqüência ordenada de tempo.

Os eventos definem a estrutura dinâmica dos modelos, assim, dado um estado inicial e dada a lógica para o processamento de cada evento, o problema 
de simulação se reduz à seqüenciação dos eventos, obtida através da lista de eventos futuros [MAC87].

As rotinas dos eventos sāo executadas conforme aparecem na lista de eventos futuros, a qual está em ordem crescente dos tempos de término dos eventos. Quando isto ocorre, o tempo de simulação é alterado para o tempo do evento na lista e o controle é transferido para a rotina associada ao evento.

Segundo MacDougall [MAC87], esta abordagem impõe uma visão global e de um único nível ao modelador, permitindo que ações de atividades logicamente não relacionadas sejam agrupadas podendo causar a perda total da identidade com a estrutura do sistema e tornar difícil sua modificação, sendo portanto, ideais para modelos de pequeno e médio porte.

Como exemplos de linguagens orientadas a eventos, tem-se: SLAM II, GASP, SIMSCRIPT, SIMAN, etc.

Linguagens orientadas a processos: são linguagens constituídas por seqüências de eventos que ocorrem em padrões definidos. Estas seqüências podem ser agrupadas constituindo um único bloco ou processo (conjunto de atividades logicamente relacionadas [SAN94a]), utilizadas pelo programador através de uma única afirmação [SOA92].

Os programas escritos nesta abordagem apresentam estrutura hierárquica [MAC87] representando fielmente as operaçōes do sistema real de forma a assegurar a validade do modelo em relação ao sistema. Isto é particularmente importante num sistema de grande porte ou sujeito a constantes mudanças.

Da mesma forma que as linguagens orientadas a evento, existe uma lista ordenada pelo tempo e um relógio. A cada avanço do tempo, as ações do processo na cabeça da lista são executadas. Quando existe mais que um processo a ser executado no mesmo instante, ou seja, quando um evento é membro de mais de um processo, as ações de cada um dos processos serão executadas conforme aparecem na lista.

Como exemplos de linguagens orientadas a processo, tem-se: GPSS, Simula, Q-GERT, SLAMII e RESQ.

Linguagens Orientadas a atividades [SOA92, ORL95, MIT92]: são aquelas nas quais 0 modelador deve descrever todas as atividades em que as entidades do sistema estão envolvidas, bem como as condições que deteminam o início e o fim de cada uma delas. Então, associada a cada atividade, há uma condição, a qual, a qualquer instante de tempo pode ser satisfeita ou não, dependendo do estado global do sistema e de um relógio de atividade interna. A cada avanço do tempo, todas atividades são examinadas e executadas se for o caso. Nesta abordagem, não existe lista de eventos futuros.

Trata-se de uma linguagem ineficiente, devido à necessidade de examinar cada atividade a cada avanço do tempo. No entanto, para certos tipos de problema, o uso desta abordagem provê um modelo conciso, útil quando o tempo de duração de cada atividade é indefinido, determinado pelo estado global do sistema [SPO94]. Trata-se de um modelo não muito adotado [MAC75, SAN94a].

SIMON.

Como exemplo de linguagens orientadas a atividades, tem-se: CSL e 


\subsubsection{Pacotes de Simulação}

São programas prontos para simular tipos especificos de sistemas [ORL95, SOA92]. O uso de um pacote de simulação apropriado, geralmente, é a ferramenta mais adequada quando se deseja simular classes específicas de problemas, propiciando uma grande economia de tempo de programação. Em compensação, são restritos a estas classes de problemas oferecendo dificuldades quando se deseja fazer alterações, sendo portanto, muito pouco flexíveis. Também oferecem dificuldades quanto à portabilidade, sendo difícil o transporte do programa de uma máquina para outra.

São divididos em duas grandes categorias [SOA92]: pacotes voltados para a avaliação de desempenho e os voltados para a resolução de problemas específicos. São exemplos: BEST/1, CMF, FIVE, PERFORMS, VMPredictos e XL (para avaliação de desempenho) e PET, MAP/, BETHSIM e SNAP (problemas específicos).

\subsubsection{Extensões funcionais}

São bibliotecas inseridas em uma linguagem de programaçāo de uso geral (linguagem hospedeira) contendo primitivas próprias do ambiente de simulação [ORL95, SPO94]. Suas vantagens são bastante claras: o uso de uma linguagem conhecida, não necessitando que o programador aprenda uma nova linguagem [SAN94a] e a portabilidade. Da mesma forma que as linguagens de simulação, também podem ser orientadas a eventos, atividades ou processos. Exemplos: smpl e EFC - extensōes da linguagem C e HPSIM e EFM-2 - extensōes da linguagem Modula 2.

\subsubsection{Slstemas Automáticos}

O crescente uso da simulação em diversas áreas, tem gerado uma necessidade cada vez maior de modelar e compreender sistemas complexos de forma rápida [SWA95]. Apesar de existirem linguagens de simulação, extensões funcionais e pacotes de simulação, ainda são muitas as restriçōes e os inconvenientes impostos quando um modelador sem experiência em programação e em simulação deseja modelar um sistema. Isto decorre, principalmente do fato de que o programa deve ser abstraído a partir de um modelo, o qual se encontra em um nivel mais alto do que aquele utilizado na programação [SPO94].

Muitos sistemas tem sido desenvolvidos no sentido de suprimir a tarefa de programação do modelador através do uso da simulação visual e interativa e de geradores de aplicações. Assim, vários ambientes automáticos têm surgido, nos quais o modelador representa graficamente (através de desenhos, diagramas e menus) o modelo a ser simulado, introduz os parâmetros, escolhe as distribuições, define os pontos de coleta de estatísticas e obtém os resultados da simulação por meio de gráficos ou histogramas. Além disso, alguns sistemas permitem que seja visualizada a animação da simulação (exemplo: QMG, GraphSIM e $\mathbf{Q}^{+}$). 
A seguir será apresentado e discutido o ASiA, um sistema automático que foi desenvolvido no ICMSC-USP.

\subsection{O ASiA (Ambiente de Simulação Automático)}

O ASiA é um sistema cujo objetivo é liberar o usuário da tarefa de elaborar - programa de simulação, uma das partes mais exaustivas do processo. Para isso, faz uso de um editor gráfico, através do qual o usuário introduz no computador o modelo (basicamente um modelo de redes de filas) e os parâmetros do sistema considerado. A partir daí, aguarda o programa (em smpl, na versão atual) gerado automaticamente, o que é feito através de um gerador de aplicações.

A figura 4.1 mostra o esquema básico do ASiA. Inicialmente, o usuário deve fornecer ao ASiA a descrição completa do modelo e outras informações, tais como, os parâmetros do modelo (tempos de serviço, política das filas, etc.), os pontos de coleta de estatísticas, os tipos de gráficos a serem apresentados no relatório final e o tipo de sistema de simulaçāo que deverá ser utilizado. Isto é feito através de um editor gráfico, o qual fornece uma interface gráfica amigável.

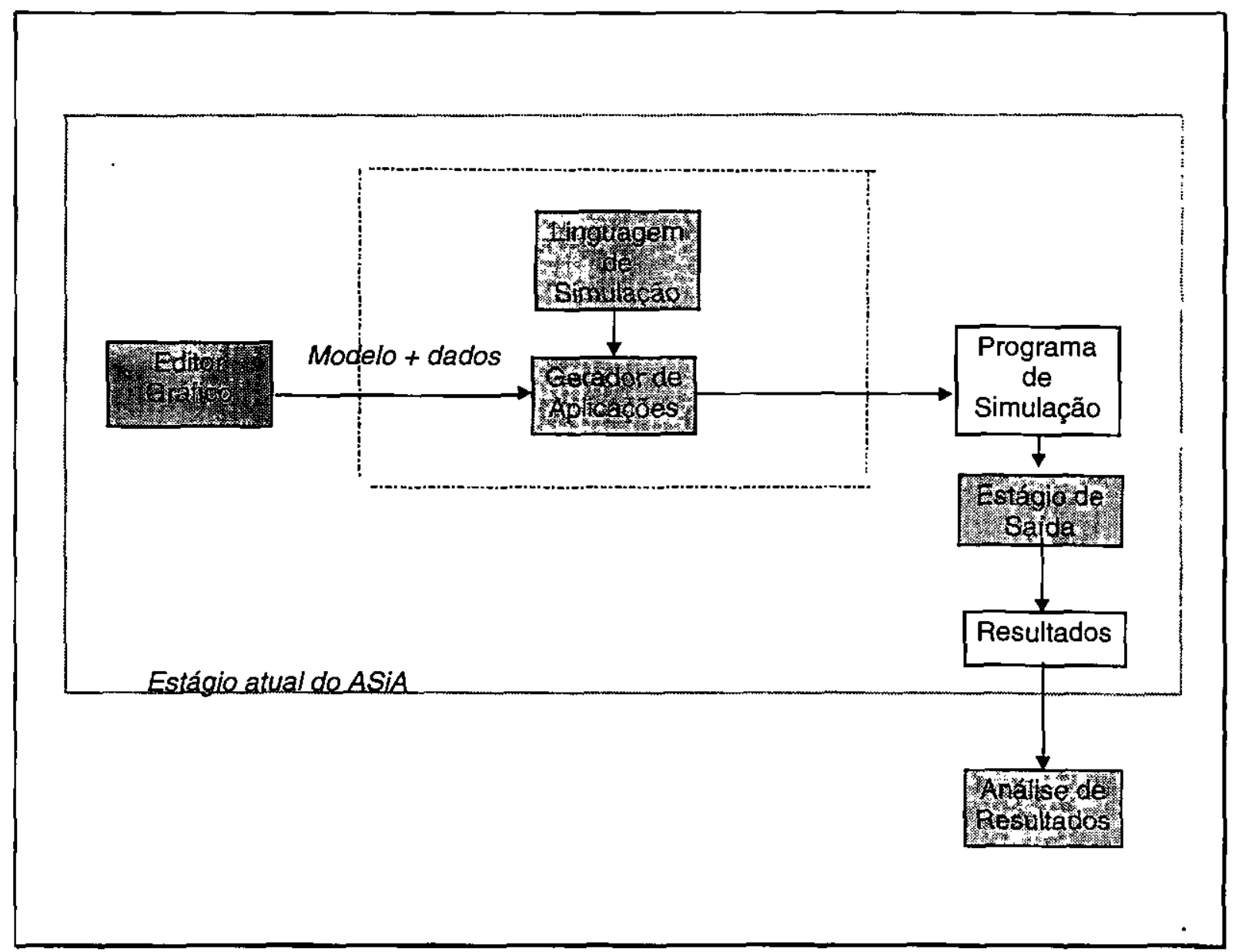

Figura 4.1: Esquema Básico do ASiA (incluindo o módulo de análise de resultados). 
Com esta etapa, conclui-se a participação do usuário no processo e estas informações são coletadas e organizadas em estruturas de dados padronizadas, as quais alimentarão o gerador de aplicações. Este, por sua vez, gera o programa de simulação conforme a linguagem de programação adotada (na versão atual, o smpl).

A seguir, o programa de simulação é executado e seus resultados são apresentados através de gráficos gerados pelo estágio de saída.

Nas próximas seções, serão apresentados alguns detalhes do editor gráfico (seção 4.3.1), dos geradores de aplicação genéricos (seção 4.3.2) e do gerador de aplicações do ASiA (seção 4.3.3).

\subsubsection{O Editor Gráfico do ASiA}

Como o objetivo do ASiA é permitir que os programas de simulação dos usuários sejam automaticamente gerados, sem que este necessite ter conhecimentos de programação, nada mais lógico do que dotá-lo de uma interface gráfica poderosa permitindo que o usuário introduza o modelo a ser simulado no sistema quase que diretamente, utilizando símbolos e notação apropriados.

Assim, o ASiA emprega um editor gráfico (EdGraf) como módulo de interface responsável por obter o modelo do sistema em estudo e seus parâmetros, estruturando-os em tabelas de especificação, as quais alimentarāo o gerador de aplicaçōes [SPO94a].

O EdGraf, além de proporcionar um diálogo amigável com o usuário através de menus e janelas, executa uma série de operações para testar a consistência e manter o modelo, gerando a tabela de especificaçōes de maneira transparente ao usuário.

Conforme mostra a figura 4.2, o modelo a ser simulado é introduzido no sistema via uma interface do usuário de fácil utilização. Esta, coloca à disposição do usuário, todos os recursos de uma interface gráfica amigável como o mouse e uma barra de ferramentas, possibilitando a representação do modelo de forma gráfica através da manipulação de símbolos próprios do modelo de redes de filas. Permite, também, a utilização de uma barra de menus, possibilitando ao usuário a introdução dos parâmetros do modelo e a execução de operações relacionadas a arquivos.

O EdGraf tem a capacidade de obter todas as informações de que necessita a partir da análise das especificações gráficas fornecida pelo usuário. Todas as informaçōes coletadas, sejam elas, modelos, parâmetros ou distribuições, são armazenadas em um formato específico para que possam ser utilizadas pelo Gerador de Aplicações. Conforme o usuário elabora seu modelo ou introduz os parâmetros, o EdGraf vai verificando a consistência do que está sendo feito e alertando o usuário quando algo não está correto, como definições incompletas, por exemplo. Desta forma, o EdGraf nunca deixa passar um modelo inconsistente.

Uma vez que as especificações do modelo estão prontas e devidamente consistentes, o EdGraf as armazena em arquivos, de forma que possam ser transferidas para o Gerador de Aplicações e para acesso ou alterações futuras. 


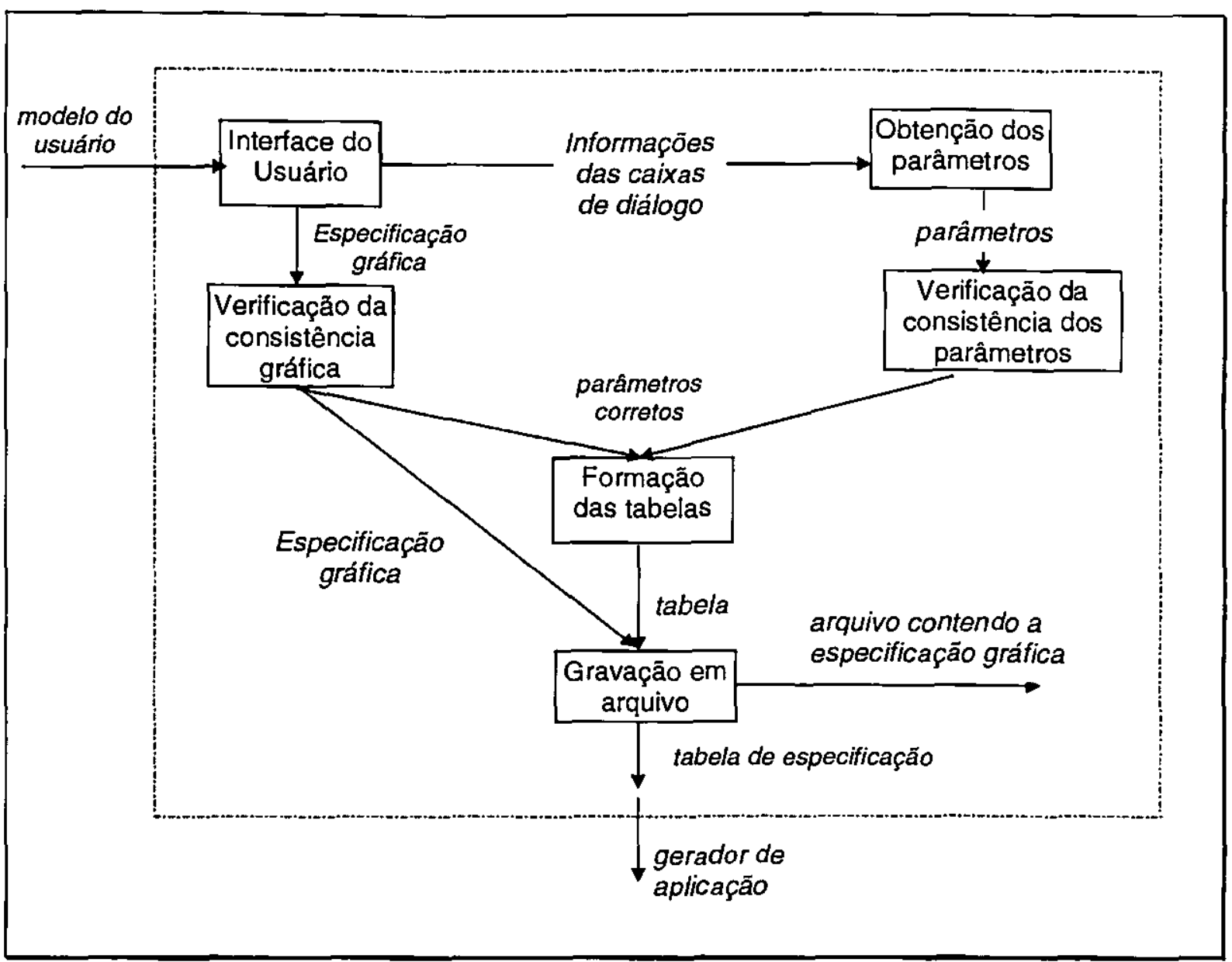

Figura 4.2: Visão Geral do EdGraf.

\subsubsection{Geradores de Aplicação}

Segundo [LUK86], um gerador de aplicações é um programa que aceita como entrada um diálogo humano estruturado e produz, em uma variedade de linguagens, um programa bem estruturado e documentado cujo objetivo é atender especificações e requerimentos particulares.

Os usuários especificam o seu problema em alto nível através de um diálogo interativo (menus), de forma gráfica (diagramas) ou de forma textual e o gerador o transforma automaticamente na sua implementação (produto final) [SPO94]. Quando uma alteração se faz necessária, basta alterar a especificação e submetê-la novamente ao gerador e uma nova implementação será produzida.

A princípio, seu funcionamento pode ser comparado ao de um compilador, mas, muitos aspectos contribuem para a sua diferenciação. Um compilador aceita declarações com rígidas regras de sintaxe ao invés de um diálogo relativamente livre e produz um programa em baixo nível numa linguagem de máquina específica. Enquanto que o gerador produz um programa estruturado, documentado, em alto nível e em várias linguagens [LUK86].

Existem geradores de aplicação desenvolvidos para atender a uma variedade de áreas de trabalho, inclusive à simulação, porém, muitos de seus elementos são os mesmos em cada uma delas. Os módulos principais de um gerador de aplicações são (figura 4.3): 
- módulo de diálogo (interface): permite que o usuário forneça suas especificações ao gerador num formato de linguagem razoavelmente livre, exercendo controle sobre a forma como isso é feito de forma a detectar omissões e inconsistências, gerando as especificações do programa.

- módulo intermediário (analisador de especificaçōes): responsável pela análise sintática e semântica da especificação do programa, simplificando o algoritmo e produzindo um meta-programa. Se este módulo for omitido, a própria especificação do usuário torna-se o meta-programa.

- módulo de geração de código (gerador de produtos): é o responsável pela geração do produto final, fazendo uso do meta-programa e das informações sintáticas referentes à linguagem em que o programa final será escrito.

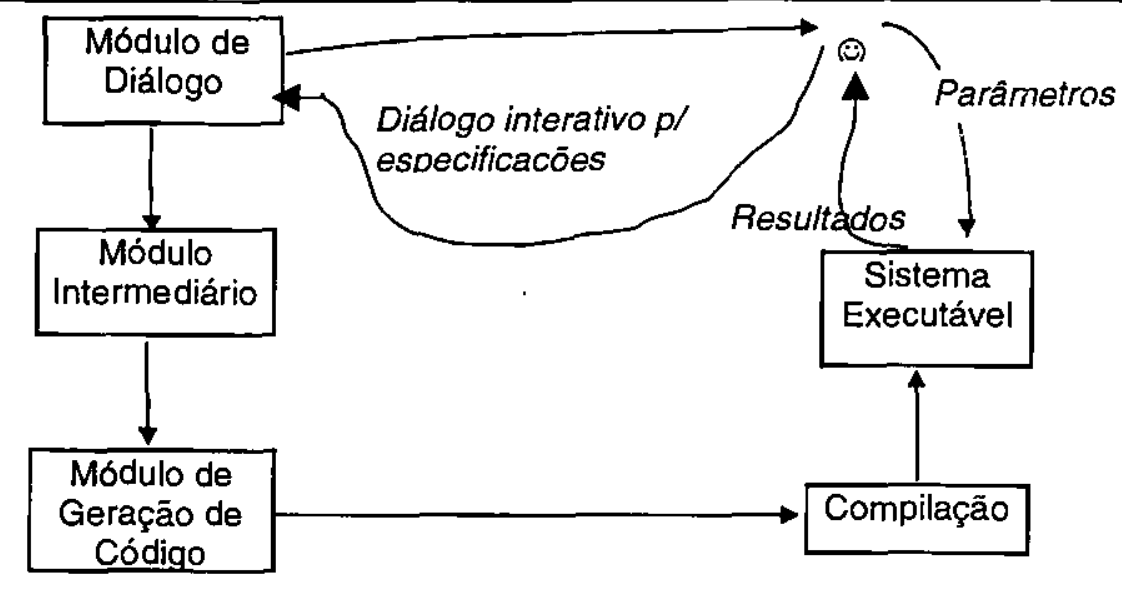

Figura 4.3: Relaçāo entre os módulos do gerador

Os geradores de aplicação são muito úteis pois possibilitam o acesso de usuários com pouca experiência em programação, produzindo códigos de programas sintaticamente corretos, facilitando sua portabilidade e permitindo a geração de programas em várias linguagens. Mesmo para usuários com bastante experiência, permitem a construçāo rápida de programas, aumentando portanto a produtividade e melhorando a qualidade do produto (facilidade de manutenção). Muitas vezes, o produto final é usado como base para a elaboração de programas mais complexos [LUK86, SPO94].

\subsubsection{O Gerador de Aplicações para o ASiA}

O Gerador de Aplicações do ASiA é implementado através dos três submódulos a seguir:

- Núcleo do Gerador: é responsável pela geração dos principais comandos em smpl referentes à preparação do modelo, definição e controle de recursos, escalonamento e geração de eventos, geração de variáveis aleatórias, 
depuração do código, coleta de dados e emissão do relatório contendo estatísticas sobre a simulação.

- Ferramentas: constitui-se do conjunto das ferramentas utilizadas pelo sistema.

- Descrição dos Produtos: a partir das tabelas de especificação geradas pelo editor gráfico, o gerador obtém todas as informações genéricas sobre o modelo $e$ as particularidades de cada um dos recursos que o compōem, além de informações sobre o escalonamento de eventos de definições de ciclos. Estas informações serão utilizadas na montagem de um gabarito, que nada mais é do que a descrição do produto específico a ser gerado, contendo trechos de código em smpl e comandos que indicam ao gerador como buscar as informações necessárias nas várias tabelas que serão utilizadas. Os trechos de código são copiados diretamente para o produto final, enquanto os comandos precedidos pelo caracter "\%" determinam as primitivas do gerador que devem ser executadas. Cada uma dessas primitivas é desdobrada num trecho específico de código no produto final. O produto final gerado é dividido em três partes: definiçōes, preparação do modelo e a implementação. Um exemplo de programa gerado em smpl é dado pela figura 4.4 [SPO94]. A descrição dos programas em linguagem $C$ que implementam este sub-módulo pode ser encontrada em [SPO94].

\subsubsection{O Estágio de Saída}

O estágio de saída consiste de um módulo de visualização dos resultados da simulação através de gráficos, desenvolvido no ambiente Windows. O usuário define o tipo de gráfico desejado (barras, pontos, linhas, etc) através de ícones e caixas de diálogo, bem como, a informação que deve ser plotada em cada eixo, a escala a ser utilizada, etc.

\subsection{Outros Sistemas Automáticos}

Inicialmente, a simulação era considerada como um último recurso para a análise: quando o problema não podia ser solucionado através de um método analítico, a única saída possível era a simulação. Com o passar do tempo, a crescente preferência dos usuários pela facilidade de uso e flexibilidade da simulação tem proporcionado o aparecimento de softwares cada vez mais poderosos e fáceis de usar (e reutilizar). Estes softwares possibilitam a análise estatística das saídas e a animação dos resultados permitindo uma análise mais apropriada dos resultados, tanto em termos qualitativos quanto quantitativos [SWA95]. Assim, a simulação, deixou de ser um mero suplemento dos métodos analíticos $e$ atualmente tem sua utilidade reconhecida como ferramenta de modelagem, sendo muito utilizada em sistemas complexos, principalmente quando há necessidade de uma análise passo a passo do comportamento do sistema. Muitas vezes pode ser utilizada para fornecer informações sobre a variabilidade ou casos extremos não disponiveis nos modelos analíticos [SWA95]. 
O número de softwares de simulação tem crescido bastante nos últimos anos, da mesma forma que o número de desenvolvedores deste tipo de ferramenta. A tendência da maioria dos produtos é apresentar animação da simulação, construção gráfica dos modelos, onde ícones e menus são utilizados ao invés de declaraçōes de programa e meios de reutilizar modelos e partes de modelos para facilitar a solução de problemas similares. Enquanto isso, aspectos como modelagem das entradas, análise estatística das saídas e apresentação dos dados gerados pela simulação evoluem num ritmo mais lento [SWA95], embora já apareçam em diversos softwares [BAN96].

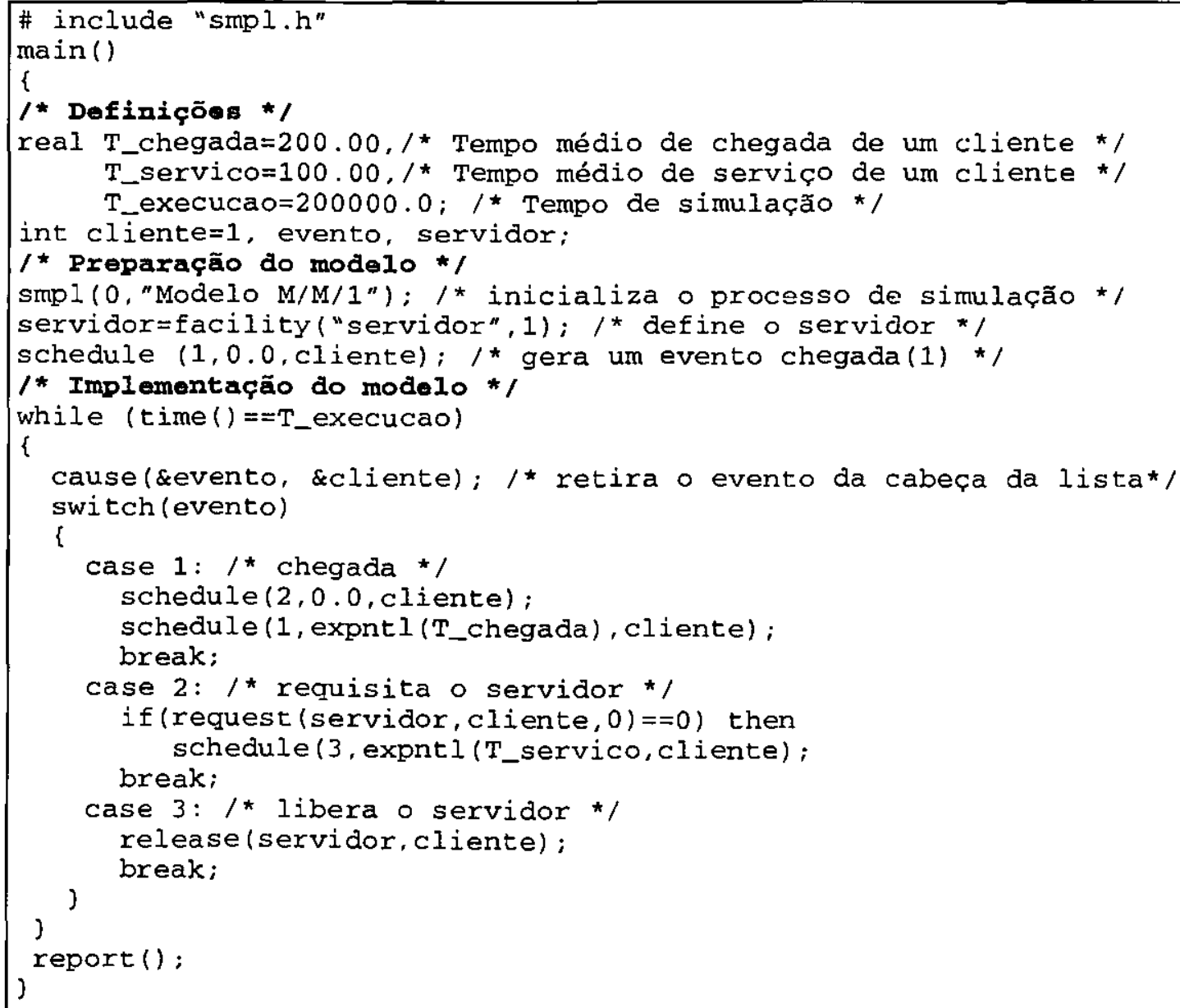

Figura 4.4: As fases no processo de execução.

Existem muitas pesquisas que visam comparar os principais softwares de simulação da atualidade. As principais características avaliadas são a construção de modelos através de gráficos e através de programação, adaptação de distribuições de entrada, suporte à análise das saídas, reutilização do modelo e animação das saídas. Alguns dos softwares que possuem estas características são: ARENA (System Modeling) que é a fusão de SIMAN e CINEMA, integrando os módulos de simulação e animação das saídas, AUTOSCHED (Auto Simulations), COMNEL III (CACl Products Co.), EXTEND (Imagine That, Inc.), GSS (Prediction Systems, Inc), MEModel (Promodel, Corp), QUEST (Deneb 
Robotics, Inc), SIMPLE++(AESOP GmbH), SIMPROCESS III (CACl Products, Co), etc. Mas, além destes, existem muitos outros: PASION (Stanislaw Raczynski), GraphSIM (), Witness (AT\&T Instel), SLAMSYSTEM (Pritsker Corp), SIGMA for WINDOWS (boyd \& fraserr Publishing Co), BONeS, especifico para a simulação de redes, etc.

Um outro conceito que vem se destacando recentemente é a construção de modelos a partir de declarações feitas em linguagem natural em associação a diagramas. Um representante desta categoria é o ASPIN (Automatic Specification Interpreter), um software próprio para a modelagem e simulação de sistemas digitais que aceita como especificações de entrada um texto escrito em linguagem natural e diagramas. O ASPIN gera estruturas conhecidas como grafos conceituais e diagramas ilustrando a interpretação das especificações de forma que possam ser validadas pelo usuário [CYR95].

\subsection{Comentários Finais}

Com o crescente aumento de adeptos da simulação tem aumentado também a necessidade por mais e melhores ferramentas de modelagem e análise. Dessa forma, muitas linguagens específicas de simulação e pacotes de simulação tem sido desenvolvidos no sentido de aliviar a carga imposta sobre o modelador que além de conhecer a área de interesse para simulação deve também dominar programação a fim de garantir que seu modelo seja bem representado pelo programa de simulação. Além das linguagens de simulação, extensões funcionais de linguagens conhecidas foram criadas, dando algum suporte à simulaçăo a partir de uma linguagem comum.

Mesmo assim, o uso de linguagens próprias para simulação ou de extensões funcionais ainda tem o inconveniente de o modelador, que pode ser um usuário comum com pouca experiência em programação, ter que dominá-la. Assim muitos sistemas automáticos têm surgido de forma a permitir que a simulação computacional seja utilizada por uma gama maior de usuários que não precisem necessariamente compreender a estrutura de um programa para poder fazer uso da simulação.

Um número considerável de ferramentas para simulação é encontrado na literatura [BEL87, RAC90, OZD91, FUN91, SWA95, BAN96]. Swain, em [SWA95] apresenta uma revisão de 54 sistemas de simulação, com custo variando de dezenas de milhares de dólares. A grande maioria destes sistemas são dedicados a uma aplicação bem definida não apresentando a flexibilidade desejada. Por exemplo, TUTSIM ( modelagem de sistemas não lineares ), RISK (análise RISK), Best Network (simulação de redes de computadores), FACTOR/AIM (análise de custo), etc. Alguns dos sistemas revisados oferecem apenas uma linguagem para simulação de sistemas de propósito geral, como é o caso do GPSS/PC e SIMNETII.

O sistema automático de interesse neste trabalho é o $\mathrm{ASiA}$, o qual permite que o usuário construa um modelo de simulação graficamente através de um editor gráfico e aguarde a elaboração automática do programa, que será feita por um gerador de aplicações. O uso de ícones e menus no editor gráfico é uma característica bastante comum nos sistemas automáticos mais atuais e tem por finalidade a criação de um ambiente amigável para o usuário. $O$ 
gerador de aplicações do ASiA produz o programa escrito na extensão funcional smpl, mas futuramente poderá ser produzido em outras linguagens ou extensōes funcionais. Outra característica importante do ASiA é a possibilidade de o usuário definir sua própria distribuição de probabilidades. $O$ objetivo deste trabalho é complementar o ASiA quanto ao aspecto de análise de saídas [BAN96].

Quanto aos outros sistemas automáticos que tem aparecido, as características mais marcantes são, geralmente, a construção gráfica do modelo, sua reutilização $e$ a animação das saídas. A modelagem das entradas $e$ análise das saídas são características que começam a ganhar destaque, apesar de serem muito necessárias.

A grande vantagem do desenvolvimento do ASiA é a possibilidade de terse um sistema de propósitos gerais e de baixo custo, ao qual se possa anexar ferramentas para áreas específicas, tais como redes de computadores, arquitetura de computadores, sistemas distribuídos, etc. Desta forma, pode-se ter em um único ambiente, ferramentas básicas para simulação de um sistema que permita a execução de simulação distribuída. Nenhum dos sistemas descritos na literatura apresenta esta característica. 


\section{CAPÍTULO 5}

\section{Análise dos Resultados}

\subsection{Introdução}

Uma vez que o programa de simulação está pronto para ser executado, livre de erros de programação e representando o modelo conforme o aspecto que se deseja estudar, surge agora um novo problema. Será que basta uma única execução do simulador para que se possa inferir sobre o comportamento do sistema? Como os valores que vão alimentar o simulador são variáveis aleatórias, é de se esperar que não. Muitas execuçōes do simulador serão necessárias para que alguma inferência possa ser feita acerca do comportamento do sistema. Mas, quantas? E para obter qual precisão? Outras questões ainda surgem: qual deve ser o estado inicial do sistema quando o simulador for iniciado - o estado vazio? Se a simulação for interrompida após um certo número de execuçōes, qual a confiança que se pode ter nos resultados obtidos?

Estas perguntas, de grande relevância dentro deste contexto são o objeto de estudo da análise das saídas da simulação [MAC87, KLE87]. Como as saídas da simulação são funções de variáveis aleatórias (as entradas) então, sua análise é um problema estatístico e as abordagens existentes para tratar este problema variam das mais simples às mais sofisticadas.

Este capitulo, aborda os problemas citados acima, apresentando meios de estimar e controlar a precisão das saídas de uma simulação.

\subsection{Considerações teóricas}

De forma a tornar clara a compreensão da abordagem que será introduzida na próxima seção, faz-se necessária a revisão de alguns conceitos estatísticos.

\subsubsection{Tipos de Simulação}

Dois tipos de simulação podem ser considerados [KLE87]:

- Simulação terminante: quando a simulação é interrompida após a ocorrência de um evento especial, ou seja, o evento é parte da descrição do sistema. Exemplo: a simulação de um combate aéreo pára quando um ou ambos os aviōes são atingidos. Na prática, a maioria das simulações é deste tipo.

- Simulação não terminante: quando não existe um evento crítico responsável por interromper a simulação e, teoricamente, ela pode prosseguir indefinidamente. Nos estudos acadêmicos, a maioria das simulações são deste tipo. 
Nas simulações terminantes, é comum considerar os resultados obtidos a partir do estado inicial (estado transitório), os quais normalmente criam complicações. Nas simulaçōes não terminantes, estes estados transitórios não criam problemas, mesmo que considerados, pois o modelador está interessado em estudar como uma determinada medida se aproxima de algum valor limitante conforme o número de rodadas caminha para o infinito (steady state) [MAC87]. $\mathrm{Na}$ simulação não terminante, os valores de saída são independentes das condições iniciais. Suponha que a medida de interesse de uma simulação seja o tempo médio de espera em uma fila. Teoricamente, conforme o número de rodadas desta simulação se aproxima do infinito, a distribuição dos tempos de espera se torna inalterável e o tempo médio de espera converge para um valor limitante, a média verdadeira ou a média da distribuição [MAC87].

\subsubsection{Medidas Usuais de Interesse}

Segundo MacDougall [MAC87], na maioria das vezes, a medida de desempenho de interesse, é a média dos valores de saída de uma simulação. Suponha que várias rodadas de uma simulação discreta produziu os resultados $X_{i}$ para uma determinada variável observada. Então, o conjunto $\left\{X_{1}, X_{2}, X_{3}, \ldots, X_{n}\right\}$ representa os resultados de uma simulação para $N$ rodadas, utilizando diferentes sementes para o gerador de números aleatórios. A média destes valores, denotada por $\bar{X}$ é:

$$
\bar{X}=\sum_{i=1}^{n} X_{i} / N
$$

É importante notar que diferentes seqüências $X_{i}$ e diferentes valores de $N$ produzirāo valores diferentes para $\bar{X}$, onde $\bar{X}$ é denominada média amostral.

No caso contínuo, tudo se comporta de maneira análoga e como para cada instante $t$ tem-se um valor para $X_{t}$, então:

$$
\bar{X}=\int_{0}^{T} X_{t} d t / T
$$

onde $T$ é o periodo observado

Conforme $N$ (ou T) converge para 0 infinito, $\bar{X}$ converge para um valor limitante $E(X)$ ou $\mu$, esperança de $X . E(X)$ é denominado média verdadeira ou média da distribuição.

Exemplo de médias discreta e contínua:

- Processo discreto: o gerente de um supermercado deseja saber se deve ou não continuar comprando um determinado produto e para isso coleciona os índices de venda do produto referentes ao período de um ano e calcula a média deste periodo. 
- Processo contínuo: o engenheiro de uma metalúrgica deseja saber qual a temperatura média de um forno industrial no decorrer do turno de trabalho.

Nem sempre, porém, a média fornece todas as informações sobre o comportamento de um sistema. Por exemplo: o simples cálculo do tempo médio de resposta num sistema interativo pode não ser suficiente para se avaliar o desempenho do sistema. Talvez seja mais útil saber alguma coisa sobre a distribuição dos tempos de resposta [MAC87]. Assim, outras medidas podem se fazer necessárias, entre elas, as que medem a dispersão de uma distribuição. Abaixo serão apresentadas outras medidas de interesse:

Variância: Dados os resultados de $N$ rodadas de uma simulação, $\left\{X_{1}, X_{2}, \ldots, X_{N}\right\}$, com média amostral $\bar{X}$ tem-se que a variância amostral $s_{x}{ }^{2}$ é dada por:

$$
s_{x}^{2}=\sum_{i=1}^{N}\left(X_{i}-\bar{X}\right)^{2} /(N-I)
$$

Conforme $N$ se aproxima do infinito, $s_{x}^{2}$ converge para um valor limitante $E\left(s_{x}^{2}\right)=E\left[(X-\mu)^{2}\right]$ ou $\sigma^{2} . \sigma^{2}$ é denotada variância da distribuição.

Desvio Padrão: é definido como a raiz quadrada da variância e denotado por $s_{x}$ (no caso amostral) e por $\sigma$ (para a distribuição).

Coeficiente de variação: é definido como o quociente do desvio padrão pela média.

Então: $v=\sigma / \mu$

Quantis ou Percentis: é possivel, muitas vezes, que se esteja interessado em saber como os resultados obtidos de uma simulação se aproximam do infinito, pois em determinados sistemas de filas, os tempos de espera individuais podem ser extremamente longos. Apesar de ser raro o interesse por este tipo de sistema, pode-se apresentar uma medida que estime este valor. Trata-se do quantil ou percentil [KLE87, MAC87]. Formalizando: deseja-se encontrar o valor de $x_{p}$, tal que:

$$
P\left(X<x_{p}\right)=p
$$

Porcentagem ou Proporcão: na equação (1), se o valor de $x_{p}$ for fixado (ao invés de $p$ ), deve-se encontrar a porcentagem dos valores menores que o valor crítico $x_{p}$ [KLE87].

Critérios Múltiplos e Inferência Simultânea: outras medidas de interesse são o tempo de espera dos clientes numa fila e a porcentagem de utilização dos recursos. Além disso, pode-se desejar quantificar cada critério individualmente através de várias estatísticas. Estas questões levam à necessidade de se fazer inferências simultâneas ou conjuntas dependendo do tipo de análise desejado. Kleijnen [KLE87] recomenda a utilização da inequação de Bonferroni a fim de 
garantir que todas as declaraçōes baseadas em cada rodada da simulação sejam válidas.

Diferença entre duas médias: segundo [BER94], o teste da diferença de médias amostrais é uma ferramenta bastante utilizada em inferência estatística. Através dele, pode-se comparar o desempenho de duas amostras com médias $x_{1}$ e $x_{2}$ através de uma única amostra constituída pelas diferenças entre cada uma das observações. Sendo $\mu_{1}$ e $\mu_{2}$ as médias das distribuições originais, tem-se a distribuição resultante com média $\delta=\mu_{1}-\mu_{2}$ [KLE87].

Para a comparação entre dois sistemas, Kleijnen [KLE87] recomenda o uso de uma mesma seqüência de números aleatórios para ambos

Exemplo: para os tempos de espera a seguir:

$X=\{2.0,5.0,4.8,3.5,2.4,8.0,17,3.0,1.5,1.2,1.4,2.8,3.1,1.7,1.8,2.4,16,15,1.4,1.3,19\}$

pede-se:

1. determinar um valor de $t$ para o qual $90 \%$ dos tempos de espera são menores ou iguais a $t$;

2. calcular a média, a variância e o desvio padrão;

3. estimar a porcentagem de usuários que esperaram menos que 2 minutos na fila.

Solução:

1. Neste caso, deve-se determinar 0.9 quantis ou 90 percentis. $O$ número de elementos desta amostra é 21 e $90 \%$ destes elementos correspondem a 18.9 elementos, ou seja, 19.

Ordenando os elementos da amostra, tem-se:

$$
1.2,1.3,1.4,1.4,1.5,1.7,1.8,2.0,2.4,2.4,2.8,3.0,3.1,3.5,4.8,5.0,8.0,15,16,17 \text { e } 19
$$

Então, o valor de $t$ para o qual $90 \%$ dos valores amostrais são menores ou iguais a ele é 16, ou de outra forma: $P(X<16)=90 \%$

2. Para o cálculo da média, variância e desvio padrão, tem-se:

$$
\begin{aligned}
& \bar{X}=\frac{\sum_{i=1}^{21} X_{i}}{21}=\frac{114.3}{21} \approx 5.442857 \\
& S_{x}^{2}=\frac{\sum_{i=1}^{21}\left(X_{1}-\bar{X}\right)^{2}}{20} \approx 34.528571 \\
& s_{x}=\sqrt{34528571} \approx 5.876101
\end{aligned}
$$


A média é um tipo especial de quantil. Por exemplo: pretende-se obter uma tendência central da distribuição dos tempos de espera numa fila [KLE87].

3. Neste caso, tem-se: $P(X<2)=7 / 21=33.33 \%$

\subsubsection{Intervalos de Confiança}

Suponha, por exemplo, que através de uma seqüência finita de simulações, obteve-se um valor $\bar{X}$ para a média de seus resultados. Não existe muito significado em obter um valor particular de $\bar{X}$ (talvez após um grande esforço) sem uma estimativa da validade deste valor, isto é, do quanto se aproxima da média da distribuição $\mu$ [MIT92]. Outro valor de interesse é o número de rodadas da simulação para se obter uma média amostral arbitrariamente próxima de $\mu$ [MAC87].

Uma medida probabilística da distância entre $\bar{X}$ e $\mu$ pode ser derivada de:

$$
P(|\mu-\bar{X}| \leq \delta)=1-\alpha \quad 0 \leq \alpha \leq 1
$$

O intervalo $(\bar{X}-\delta, \bar{X}+\delta)$ é denominado intervalo de confiança para $\mu$. A probabilidade $J-\alpha$ é o nível de confiança e pode ser entendida como a probabilidade que o valor absoluto da diferença entre a média amostral $\bar{X}$ e a média da distribuição $\mu$ seja menor ou igual a $\delta$. O valor do nível de confiança, normalmente, é especificado pelo analista, mas, tipicamente é considerado como 0.90 ou 0.95 . O valor de $\delta$ é determinado pelos valores amostrais, pelo número de amostras e por $\alpha$ [MAC87], seguindo a seguinte expressāo:

onde:

$$
\delta=t_{\alpha 2 ; N}-1 \cdot s / N^{1 / 2}
$$

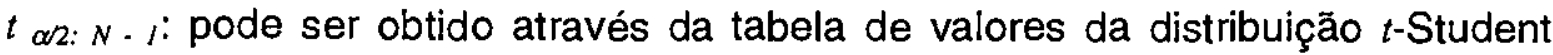
com $N$-l graus de liberdade. Parte desta tabela pode ser observada na figura 5.1;

$s / N^{1 / 2}$ : desvio padrão da distribuição da média amostral.

O exemplo que será apresentado a seguir é proveniente de [MAC87] e ilustra os conceitos introduzidos nesta seção.

Exemplo: estimação do tempo médio de espera num sistema de filas $M / M / 1$.

Tempo médio entre as chegadas: 125

Tempo médio de serviço...............: 100

$X_{i}=$ tempo que o cliente $\mathrm{i}$ aguarda na fila

$\bar{X}=$ tempo médio obtido na simulação de 5000 clientes

Pergunta-se: quanto $\bar{X}$ está próximo de $\mu$ ? 
Foram executadas 10 rodadas de simulação (cada qual para 5000 clientes) e obteve-se os seguintes resultados para $X$ :
(1) 331.993
(5) 393.393
(9) 492.144
(2) 366.052
(6) 447.532
(10) 389.200
(3) 403.524
(7) 420.858
(4) 464.856
(8) 355.959

As médias obtidas variam de 331.993 a 492.144 , o que ilustra o erro que seria cometido se apenas uma rodada de simulação fosse efetuada. A média das 10 rodadas é 406.554 .

Como $\delta$ é uma função de variáveis aleatórias (pois depende dos valores amostrais), também é uma variável aleatória. O intervalo $\bar{X} \pm \delta$ também é um intervalo aleatório.

Quando $X_{1}, X_{2}, \ldots, X_{n}$ são variáveis aleatórias independentes com distribuição normal de média $\mu, \delta$ é dado por:

$$
\delta=t_{\alpha / 2} \cdot N \cdot 1 \cdot s /{ }_{N}^{1 / 2}
$$

Então:

média amostral $\quad \bar{X}=406.55$

variância amostral $s^{2}=2540.08$

$s / N^{1 / 2}=15.94$

$t_{0.05 / ; 9}=2.26($ pela tabela 5.1$)$

semi-amplitude do intervalo de confiança $=36.02$

$$
\text { Intervalo de confiança }=406.55 \pm 36.02
$$

Este resultado assegura que há uma chance de $95 \%$ de o tempo médio verdadeiro de espera na fila estar entre 370.33 e 442.47 .

Se este experimento for repetido um número muito grande de vezes, e em cada experimento for computado o intervalo de confiança, pode-se dizer que $95 \%$ destes intervalos conterão efetivamente a média verdadeira.

Dos valores médios obtidos através das 10 rodadas efetuadas apenas 4 deles estão dentro do intervalo de confiança, pois a média teórica para esta distribuição é 400.

Âs vezes o intervalo de confiança pode ser descrito em termos de uma porcentagem da média. Por exemplo, pelo que foi visto anteriormente, a semi- 
amplitude do intervalo de confiança (36.02) corresponde a $8.86 \%$ da média amostral (406.55).

\begin{tabular}{|c|c|c|}
\hline 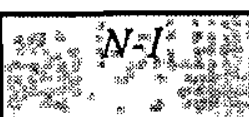 & $=0,2=0.05$ & $\alpha / 2=0.025$ \\
\hline 4 & 2.13 & 2.78 \\
\hline 5 & 2.02 & 2.57 \\
\hline 6 & 1.94 & 2.45 \\
\hline 7 & 1.90 & 2.37 \\
\hline 8 & 1.86 & 2.31 \\
\hline 9 & 1.83 & 2.26 \\
\hline 10 & 1.81 & 2.23 \\
\hline 11 & 1.80 & 2.20 \\
\hline 12 & 1.78 & 2.18 \\
\hline
\end{tabular}

Tabela 5.1: Valores selecionados para $t_{\alpha / 2: N \cdot 1}$

\subsubsection{Correlação entre os dados amostrais}

O cálculo do intervalo de confiança feito na seção anterior, não poderá ser aplicado diretamente aos resultados de uma simulação se os dados forem correlacionados, pois esta estimação requer a suposição de independência [MAC87, BER94].

Considere a seguinte amostra com $n$ observaçōes $\left\{X_{i} ; 1 \leq i \leq n\right\}$. O objetivo é determinar a extensão da correlação que pode existir na seqüência dos dados.

Define-se função autocovariância de $\left\{X_{j}\right\}$ à função $\left\{R_{k}\right\}$ onde:

$$
R_{k}=E\left[\left(X_{j}-\mu\right)\left(X_{j+k}-\mu\right)\right]
$$

para todo $k e j$, onde $k$ é a distância de $j$ em uma amostra indexada.

Define-se $\rho_{k}$ como o coeficiente serial de $\operatorname{lag} k$ (ou ordem $k$ ), onde:

$$
\rho_{k}=R_{k} / R_{0}=R_{k} / \sigma^{2} \quad-\infty \leq k \leq \infty
$$

A seqüência $\left\{\rho_{k}\right\}$ é definida como seqüência de autocorrelação, sendo que:

$$
-1 \leq \rho_{k} \leq l \text { e } \rho_{0}=1
$$

Quanto mais próximo $\rho$ estiver de 1 ou de -1 , mais correlacionados serão os valores amostrais. Se $\rho=0$, pode-se dizer que as variáveis são nãocorrelacionadas, podendo ser ou não independentes.

Assim, o cálculo do intervalo de confiança envolve a variância da média amostral, que no caso de variáveis aleatórias não correlacionadas, pode ser estimada por $s^{2} / N$. A média $\mu$, ao contrário, mesmo no caso de variáveis correlacionadas pode ser estimada por $\overline{\mathrm{X}}$, conforme definida no início deste capítulo. 
Demonstra-se [KOB81] que:

$$
\operatorname{Var}(\bar{X})=\left[1+2 \sum_{j=1}^{n+1}(1-j / n) \rho_{j}\right] \sigma^{2} / N
$$

Conforme $N$ se aproxima do infinito, $\rho_{i}$ se aproxima de zero e pode-se dizer que:

$$
\begin{gathered}
\operatorname{Var}(\bar{X}) \approx \sigma^{2} / N \text { ou } \operatorname{Var}(\bar{X})=\xi \sigma^{2} / N \text { e daí } \operatorname{Var}(\bar{X})=\sigma^{2} /(N / \xi) \\
\text { e } \\
\xi=1+2 \sum_{j=I}^{\infty} \rho_{j}
\end{gathered}
$$

$\xi$ pode ser visto como o número de amostras correlacionadas equivalentes a uma amostra independente. $O$ quociente $N / \xi$ pode ser entendido como 0 tamanho efetivo da amostra.

$\mathrm{Se}$ os valores amostrais forem independentes (não correlacionados), então, $\xi=1$ e $\operatorname{Var}(\bar{X})=\sigma^{2} / N$. Neste caso, a variância da média amostral pode ser estimada da variância amostral $s^{2} / N$. Se os valores amostrais estiverem correlacionados, então $\xi>1$ e $\operatorname{Var}(\bar{X})>\sigma^{2} / N$. Neste caso, um intervalo de confiança baseado na variância da média amostral $s^{2} / N$ subestimará a amplitude do intervalo de confiança dando uma falsa idéia de precisão dos resultados da simulação.

Existem muitos métodos para coleta e análise de dados provenientes de uma simulação. Muitos deles tentam diminuir ou remover as dependências entre as observações ou ainda procuram explorar a natureza correlacionada das mesmas na análise da variância, necessária para determinar os intervalos de confiança dos parâmetros estimados [SAN94].

$\mathrm{Na}$ seção 5.3.3 serão descritos dois métodos de análise de saída, nos quais obtém-se $N$ estimativas independentes do valor médio dos parâmetros de saída de interesse e utiliza-se as fórmulas anteriores para o cálculo do intervalo de confiança. Para obter independência, utiliza-se rodadas independentes ou sub-rodadas de uma rodada grande, tomando-as grande o suficiente para que a média das sub-rodadas consecutivas seja independente.

\subsubsection{Considerações sobre a Normalidade}

O Teorema do Limite Central estabelece que a média de $n$ variáveis independentes e identicamente distribuídas é aproximadamente normalmente distribuída para valores grandes de $n$. Neste caso, a distribuição da média amostral é dita assintoticamente normal.

Numa simulação, porém, os resultados podem ter a mesma distribuição (exceto no período de warm up, cujos resultados normalmente são desprezados), mas é muito difícil obter valores independentes. Mesmo assim, existem duas razões que permitem que o teorema acima possa ser aplicado aos resultados de uma simulação: 
- já foi demonstrado de maneira geral para certos tipos de processos e para certos parâmetros de saída de certos sistemas de fila que a normalidade assintótica pode ser considerada mesmo que os processos sejam correlacionados.

- para contornar os problemas de warm up e da correlação em uma simulação são utilizados valores muito grandes de $n$. Isso já é suficiente para que a normalidade seja atingida.

Assim, a distribuição média dos resultados da simulação será considerada como sendo assintoticamente normal.

\subsubsection{Teste de Hipóteses}

É o processo que permite decidir se uma hipótese deve ser aceita ou não, ou se as observações diferem significativamente dos resultados esperados [SPI78]. Muitas vezes, é utilizado para decidir se uma afirmação feita por um parâmetro é falsa ou verdadeira [SOA92].

Para isso, são definidos dois tipos de hipóteses: a hipótese nula $\left(H_{0}\right)$, estabelecida para se determinar se ela pode ou não ser rejeitada em favor da hipótese substituta $\left(H_{1}\right)$.

Exemplo: Deseja-se decidir se um determinado processo é melhor que outro, estabelecendo a hipótese $\left(H_{0}\right)$ de que não há diferença entre eles e a outra hipótese $\left(H_{1}\right)$ denotando a diferença.

Ao se efetuar um teste de hipóteses, pode-se cometer dois tipos de erro:

- Erro do tipo 1: uma hipótese que deveria ser aceita é rejeitada

- Erro do tipo 2: uma hipótese que deveria ser rejeitada é aceita

A cada tipo de erro está associada uma probabilidade, $\alpha$ e $\beta$ respectivamente. A probabilidade $\alpha$ é denominada nível de significância e indica a probabilidade de hipótese ser rejeitada quando ela deveria ser aceita [SPI78, SOA92].

Exemplo: Suponha que um nível de significância de 0.05 foi adotado num determinado teste de hipóteses. Isto significa que tem-se apenas 5 chances em 100 de rejeitar uma hipótese verdadeira. Assim, tem-se $95 \%$ de certeza de tomar a decisão correta. Neste caso, pode-se dizer que a hipótese foi rejeitada ao nível de $5 \%$ de significância [SPI78].

\subsection{Análise das Saídas}

Como visto anteriormente, o objetivo da análise das saídas de uma simulação é verificar se os resultados são satisfatórios e suficientes para o estudo do modelo que está sendo simulado [BER94]. 
Os métodos existentes de análise das saídas visam resolver problemas relacionados à existência de um período transiente inicial (warm up) ou à correlaçāo entre os resultados observados.

Dos métodos tratados neste trabalho, alguns tentam remover os efeitos da correlação, como o método das replicaçōes, da média dos lotes e da regeneração. Outros, tentam estimá-la, como o método da autoregressão e da análise espectral. Um outro método ainda, o das série padronizadas, efetua transformações na seqüência de saída.

A seguir serão apresentadas algumas abordagens para estimativa do intervalo de confiança empregadas no estudo dos métodos. Posteriormente, será apresentado com mais detalhes o período de warm up e finalmente os métodos de análise.

\subsubsection{Estimação do Intervalo de Confiança}

O que ocorre com muita freqüência na prática, é que muitos usuários escolhem tamanhos arbitrários de amostra e fazem suas simulações esperando ingenuamente que as estimativas obtidas sejam suficientemente precisas [KOB81]. O fato de eles estarem incorrendo em erros é evidente. A existência, na literatura, de muitos procedimentos elaborados para a estimação do intervalo de confiança dos estimadores traduz esta preocupação. Normalmente, estes procedimentos seguem uma das duas abordagens a seguir: estimação do intervalo de confiança tendo fixado anteriormente o tamanho da amostra ou fixando o intervalo de confiança anteriormente e procurando o tamanho da amostra necessário para a construção deste intervalo. Estas duas abordagens serão tratadas a seguir [MAC87, SAN94].

\subsubsection{Procedimento da Amostra de Tamanho Fixo}

É aquele em que um experimento de simulação de comprimento fixo é realizado e o intervalo de confiança é estimado a partir de seus resultados [MAC87]. Nem sempre é um procedimento muito apropriado, pois, se o comprimento da rodada de simulação for muito pequeno, a porcentagem de cobertura para a variável de interesse pode ser consideravelmente menor que a desejada, produzindo resultados nada conclusivos. Ao contrário, se o comprimento for suficientemente grande, a porcentagem de cobertura proporcionada pelos intervalos de confiança para os dados de saída será adequada apenas para o sistema considerado [BER94].

A questão do comprimento da rodada de simulação é problemática: um valor considerado suficiente para um determinado sistema pode não o ser para outro [BER94].

É importante ressaltar também que o valor para o intervalo de confiança obtido desta maneira pode apenas ser estimado, mas não controlado [MAC87].

\subsubsection{Procedimento Seqüencial}

Ao contrário do procedimento anterior, a precisão é fixada anteriormente e as estimativas para o intervalo de confiança são computadas em intervalos de 
tempo selecionados, prosseguindo com o experimento até que a precisão desejada seja alcançada [MAC87, SAN94].

Normalmente, inicia-se com um comprimento mínimo de rodada, o qual será seqüencialmente incrementado, durante o curso da simulação até que seja possível construir um intervalo de confiança com a precisão desejada [SAN94].

Existem vários procedimentos seqüenciais os quais utilizam os métodos de coleta de dados que serão apresentados na seção 5.3.3. Os mais conhecidos são: o de Fishman, usando o método regenerativo, o de Lavenberg e Sauer, também com o método regenerativo, o de Mechanic e McKay, com o método das médias dos lotes e o de Law e Carson, também com o método das médias dos lotes [SAN94].

\subsubsection{O período transiente (warm up)}

Uma fonte de muitos erros na análise dos dados obtidos em simulação surge quando a coleta de dados é feita levando-se em consideração o período em que o sistema estava em desequilíbrio [SAN94]. Este, é conhecido como período transiente ou warm up. Como os sistemas estudados normalmente estão em equilibrio, a coleta de dados efetuada durante o warm up pode gerar resultados que apresentem desvios dos valores estimados em relação às medidas verdadeiras. Isto também vai depender da importância que a consideração do estado de warm up vai ter para a análise do sistema, ou seja; se o interesse está no estado transitório ou permanente do sistema [SOA92]. Se o sistema for estável, após o período de warm up ele se aproxima do equilíbrio. Caso contrário, fica permanentemente em desequilíbrio. A duraçāo do periodo de warm up depende das condiçōes iniciais e das características do sistema.

Existem diversas regras para a determinação do período de warm up. Odoni e Roth [ODO83, SAN94] sugerem o seguinte cálculo:

$$
\tau=\frac{C_{a}^{2}+C_{s}^{2}}{2.8 \mu\left(1-\sqrt{\rho)^{2}}\right.}
$$

onde:

- $C_{a}^{2} e C_{b}^{2}$ são respectivamente os coeficientes de variação para os tempos entre chegadas e o tempo de serviço;

- $1 / \mu$ é o tempo médio de serviço;

- $\rho$ é a taxa de ocupação do sistema.

Outra regra, [PAW90, SAN94] assume que o efeito do período de warm up termina logo após o comprimento inicial correspondendo a $2 \%$ do total da rodada de simulação.

Várias abordagens são utilizadas com a finalidade de superar os efeitos do warm up [MAC87, ORL95]: 
1. Definir condicōes iniciais representando o estado de equilibrio do sistema: ao invés de partir do estado inicial mais simples, o estado vazio, o sistema seria iniciado já com o estado de equilíbrio [BER94, SOA92]. Trata-se, porém, de uma tarefa difícil, pois, além de não ser claro como estas condições podem ser definidas, a própria criação destas condiçōes requer um esforço considerável, pois implica em distribuir tarefas através dos recursos e entidades do sistema de maneira pré-determinada.

2. Desprezar os primeiros valores amostrais: esta abordagem permite que as medidas de interesse se aproximem mais rapidamente de seus correspondentes valores teóricos, mas o problema reside em determinar o número de valores amostrais que podem ser desprezados (ponto de truncamento), em outras palavras, quando se atinge o equilíbrio.

3. Tornar o comprimento da rodada de simulação suficientemente grande: isto reduz consideravelmente os efeitos do warm up sem ter que determinar as condiçōes iniciais representativas do equilíbrio e sem ter que determinar o ponto de truncamento. Mas, é importante ressaltar que quanto maior a duração do periodo de warm up, maior deve ser o comprimento da rodada de simulação [SOA92].

\subsubsection{Métodos de Análise de Saídas}

Serão apresentados a seguir os métodos mais conhecidos que visam resolver os problemas causados pelo período de warm up e pela correlação existente entre os dados coletados.

\subsubsection{Método da Replicação}

Este é o método de análise de saídas mais simples, consistindo da execução de $K$ rodadas ou replicações de uma simulação, sendo que, em cada rodada obtém-se $m$ valores amostrais de uma variável aleatória de saída $y$ utilizando, para tal, diferentes seqüências de números aleatórios.

Em cada rodada, determina-se a média $Y$ dos valores amostrais, obtendo a seqüência $Y_{l}, Y_{2}, \ldots, Y_{k}$ onde $Y_{i}$ é a média da i-ésima rodada, com $l \leq i \leq k$.

Como foi destacado acima, diferentes seqüências de números aleatórios foram utilizadas em cada rodada e para valores de $m$ suficientemente grandes, a função de distribuição das médias é aproximadamente normal. Este fato, permite que um intervalo de confiança com distribuição $t$-Student com $k-l$ graus de liberdade possa ser construído:

$$
H=t_{\alpha / 2:-1} s / k^{1 / 2}
$$

onde:

$\bar{Y} \pm H$ é o intervalo de confiança

$\bar{Y}$ é denominada a média grande e é a média das médias amostrais. 
Quando o procedimento de amostras de tamanho fixo é adotado em replicação, o número total de observações $n$ deve ser previamente conhecido. Uma vez definido o valor de $n$, é importante decidir agora qual deve ser o número de rodadas $(k)$ e o número de observações em cada rodada $(m)$. MacDougall, em [MAC87], aconselha a manter o número de rodadas relativamente pequeno (5 ou 10) e o número de observações relativamente grande.

Pela equaçāo da semi-amplitude do intervalo de confiança, tem-se que: conforme o valor de $k$ diminui, $\mathrm{H}$ aumenta. Mas, se $k$ for diminuído para um $n$ constante, então $m$ deve aumentar. Por outro lado, se $m$ aumenta, mais $s^{2}$ (a variância amostral) é reduzida, diminuindo o valor de $H$, compensando o efeito de um pequeno número de replicações. Também é importante ressaltar que quanto maior o valor de $m$, menor o efeito do warm up e melhor a normalidade. Isso aumenta a cobertura do intervalo de confiança.

Quando o procedimento seqüencial é adotado, tanto $m$ como $k$ podem ser incrementados até que $H$ seja reduzido ao valor desejado. Normalmente, isso é feito executando-se inicialmente $k$ rodadas de simulação com um número de observaçōes $m_{0}$. Para cada conjunto de $k$ rodadas é computado o valor de $H$. Se ele for maior que 0 desejado, incrementa-se $m$ e reiniciam as rodadas computando o valor de $H$ ao final delas. Apesar de $k$ ser mantido pequeno, este processo tem o inconveniente de ter que salvar o estado da simulação a cada rodada e ser reiniciado caso $H$ não seja o desejado. A cobertura real obtida deste processo é, geralmente, menor que $l-\alpha$, podendo ser este fato atribuído ao warm up existente quando $m$ for pequeno.

Como exemplo do conflito entre $m$ e $k$ considere um experimento de $k$ rodadas de $m$ observações no qual pretende-se saber qual deve ser o valor de $n$ para o qual uma precisão de $10 \%$ seja obtida.

Então: $H=0.10 \mu$ e $\alpha=0.05$ (pois, $1-\alpha=0.95$ )

$$
\begin{gathered}
H=z_{\alpha / 2}\left[\sigma^{2} / n\right]^{1 / 2} \\
0.10 \mu=1.96\left[\xi \sigma^{2} / n\right]^{12} \Rightarrow 0.10 \mu=1.96\left[\xi^{12} \sigma / n^{1 / 2}\right] \\
n^{1 / 2}=(1.96 / 0.10 \mu) \xi^{1 / 2} \sigma \Rightarrow n=\left[(19.6 / \mu) \xi^{1 / 2} \sigma\right]^{2} \Rightarrow \xi(19.6 \sigma / \mu)^{2}
\end{gathered}
$$

Para a intensidade de tráfego igual a 0.8 , tem-se (pela tabela 5.2):

$$
\begin{aligned}
& \sigma / \mu=1.225 \\
& \xi=82.333
\end{aligned}
$$

Então, $n \approx 47.463$ 


\begin{tabular}{|c|r|r|r|}
\hline $\begin{array}{c}\text { Intensidade do } \\
\text { tráfego }\end{array}$ & $\begin{array}{c}\text { Soma dos } \\
\text { coefientes de } \\
\text { correlação }\end{array}$ & $\begin{array}{c}\text { coeficiente de } \\
\text { variação }\end{array}$ & $\begin{array}{c}\text { tamanho de } \\
\text { amostra } \\
\text { necessário }\end{array}$ \\
\hline 0.05 & 1.273 & 6.245 & 76290 \\
\hline 0.10 & 1.599 & 4.359 & 46685 \\
\hline 0.20 & 2.472 & 3.000 & 34187 \\
\hline 0.30 & 3.802 & 2.381 & 33126 \\
\hline 0.40 & 5.944 & 2.000 & 36535 \\
\hline 0.50 & 9.667 & 1.732 & 44564 \\
\hline 0.60 & 16.857 & 1.526 & 60354 \\
\hline 0.70 & 33.188 & 1.363 & 94703 \\
\hline 0.80 & 82.333 & 1.225 & 189774 \\
\hline 0.90 & 362.636 & 1.105 & 680948 \\
\hline
\end{tabular}

Tabela 5.2: Tamanhos de amostra conforme a intensidade de tráfego para uma precisão de $\mathbf{5 \%}$.

É importante lembrar que $k$ deve ser mantido relativamente pequeno $(5$ ou 10) enquanto que $m$ deve ser relativamente grande. Neste caso, $m$ deve ser aproximadamente 10000 ou 5000. MacDougall em [MAC87], recomenda o seguinte procedimento para a aplicação do método de replicação de forma a garantir uma boa cobertura para o intervalo de confiança. Trata-se de um procedimento seqüencial que supõe uma semi-amplitude de $10 \%$ a um nível de confiança de $95 \%$ para uma variável de saída $y$ :

1. Utilizar um comprimento inicial de rodada igual a 2500 valores amostrais. Se as variáveis de entrada que mais contribuem para o valor de y têm coeficiente de variação maior que 1 , aumente este valor para 4000. Para sistemas abertos com alto nivel de utilização, este valor deve ser aumentado para 5000. Estes sistemas usualmente têm intensidade de tráfego variando entre 0.6 e 0.9 .

2. Fazer 5 replicações e no final calcular a semi-amplitude $H_{5}$ do intervalo de confiança.

3. Se $H_{5}<0.10 \bar{Y}$, a precisão desejada foi alcançada. Caso contrário, fazer $K^{*}-5$ replicações adicionais, onde: $K^{*}=\left\lceil 5\left(H_{5} / 0.10 \bar{Y}\right)^{2}\right\rceil$ e ao final, computar novamente a semi-amplitude para o intervalo de confiança. Isto deve produzir a precisão almejada. Se $K^{*}>20$, é aconselhável começar novamente, porém, com comprimento de rodada no mínimo, dobrado.

4. Para um processo contínuo no tempo, onde o comprimento das rodadas é especificado em termos do tempo, como na estimativa do comprimento médio de uma fila, deve ser adotada uma execução longa o bastante para abranger um número de atividades comparável aos recomendados acima.

O fundamento para estes valores de comprimento de rodadas é empírico, sendo que o aumento sugerido visa compensar os efeitos da alta variabilidade $e$ da alta correlação. Para alguns modelos, os tamanhos totais das amostras sugeridos pelas recomendações serão maiores que o necessário, mas isso garante uma boa cobertura.

\subsubsection{Método das Médias dos Lotes (Batch Means)}

Neste método, ao contrário do método das replicações, uma única rodada longa de $n$ observaçōes é dividida em $K$ lotes (ou batches) não sobrepostos, cada 
um deles contendo $m$ observações. Para cada lote é calculada a sua média e a partir desta, a média grande e o intervalo de confiança. Se o intervalo de confiança obtido é o desejado, o processo é concluído, caso contrário, um novo lote é obtido, uma nova média grande é calculada, assim como, um novo intervalo de confiança [ORL95, MAC87, SAN94].Este processo é ilustrado pela figura 5.1.

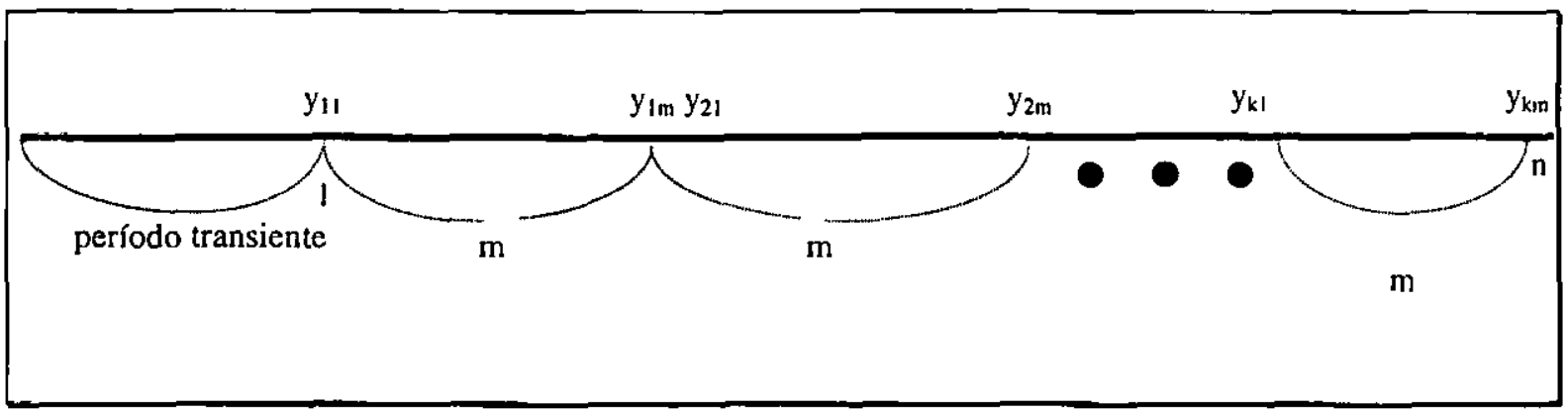

Figura 5.1: Processo de divisāo da rodada em lotes

Este método, minimiza os efeitos do warm up, pois este é tratado uma única vez no primeiro lote, eliminando-se um determinado número de observaçōes, ao contrário do método das replicaçōes, em que o warm up ocorre em cada uma das $K$ rodadas. Isto permite que o tamanho do lote seja menor que o comprimento das rodadas do método das replicações e que o número inicial de lotes seja maior que 0 número inicial de replicações produzindo uma convergência mais rápida da semi-amplitude do valor desejado para alguns processos [MAC87]. Desta forma, poucos valores sāo necessários para se atingir a precisāo desejada, contribuindo para tornar a técnica bastante eficiente [MAC87, ORL95, BER94]. A partir do segundo lote, o sistema se encontra em equilíbrio.

Da mesma forma que no método das replicaçōes, o intervalo de confiança pode ser construído conforme já especificado, desde que o tamanho $m$ do lote seja suficientemente grande de forma que a média dos lotes seja aproximadamente independente e identicamente distribuída [BER94].

Assim, percebe-se que o problema com este método está exatamente em determinar qual deve se o tamanho do lote para que as médias não sejam correlacionadas [MAC87, BER94], pois, desde que valores sucessivos das variáveis de saída são correlacionados, as médias de lotes sucessivos também o serăo, a menos que o tamanho do lote seja suficientemente grande. Caso contrário, a semi-amplitude do intervalo de confiança será subestimada [MAC87].

O que ocorre também com freqüência, é que para alguns modelos, o comprimento da rodada será bem maior que o necessário. Mas, ainda é preferivel para garantir bons resultados [MAC87].

Muitos algoritmos têm sido desenvolvidos parra determinação do tamanho do lote. Entre eles, o de Law e Carson [LAW79, MAC87] e o de Adam [ADA83, MAC87]. A extensão funcional smpl [MAC87] utiliza este último algoritmo.

O método das médias dos lotes pode ser utilizado tanto com uma amostra de tamanho fixo, como através de um procedimento seqüencial. MacDougall em [MAC87] recomenda o seguinte procedimento seqüencial para o método das 
médias dos lotes, visando obter uma precisão de $10 \%$ a um nivel de confiança de $95 \%$ :

1. Utilizar um lote de tamanho m igual a metade do comprimento de rodada inicial recomendado para o método das replicaçōes:

2. Desprezar $L=0.1 \mathrm{~m}$ observações iniciais da rodada;

3. Obter $K=10$ lotes e computar a semi-amplitude $H$ para o intervalo de confiança;

4. Se a precisão alcançada não foi a desejada, obter outro lote e computar novamente o valor de $H$. Repetir este passo enquanto necessário.

\subsubsection{Método da Regeneração}

Segundo Kobayashi [KOB81], um sistema estocástico é denominado regenerativo se existe um estado específico tal que, quando o sistema retorna a este estado, seus estados passados deixam de ter influência sobre seus estados futuros. O estado específico mencionado é denominado estado de regeneração [MAC87, SAN94].

A cada dois pontos de regeneração consecutivos, tem-se um ciclo regenerativo. Estes ciclos, então, serão os lotes de tamanho não determinístico utilizados neste método. Cada um deles se inicia quando o sistema atinge o estado de regeneração e a partir daí, o comportamento do sistema toma-se totalmente independente do comportamento em ciclos passados, dependendo apenas do estado regenerativo. O ciclo termina assim que o sistema retorna a este estado. Os dados são coletados a cada ciclo e através das médias individuais dos lotes, a média grande e o intervalo de confiança são computados da mesma forma que no método Batch Means.

Se o tempo entre dois pontos de regeneração sucessivos é finito, então as observações feitas neste ciclo são estatisticamente independentes das observações feitas nos outros ciclos [KOB81]. Além disso, as observações efetuadas em cada ciclo são identicamente distribuídas.

Os problemas com o uso deste método estão relacionados com a determinação dos pontos de regeneração corretos e também com a forma pela qual eles devem ser detectados pelo processo de simulação [SOA92, ORL95]. Para que possa ser utilizado, é necessário a ocorrência freqüente do estado regenerativo. Normalmente, recomenda-se em tomo de 30 ciclos de regeneraçāo [SOA92, SAN94]. Outros fatores restringem seu uso: comprimento muito grande do ciclo regenerativo, número muito pequeno de ciclos regenerativos, o que torna a seu desempenho inferior a do método Batch Means e o fato de que a maioria dos sistemas reais não possuem pontos de regeneração [SAN94].

A figura 5.2 mostra um processo que conta o número de clientes num sistema de filas $M / M / 1$ [SAN94].

Da mesma forma que o método Batch Means, este método também tem a vantagem de uma execução única [SOA92] e da superação dos efeitos de warm up, pois a coleta de dados é iniciada quando o estado regenerativo é atingido. 


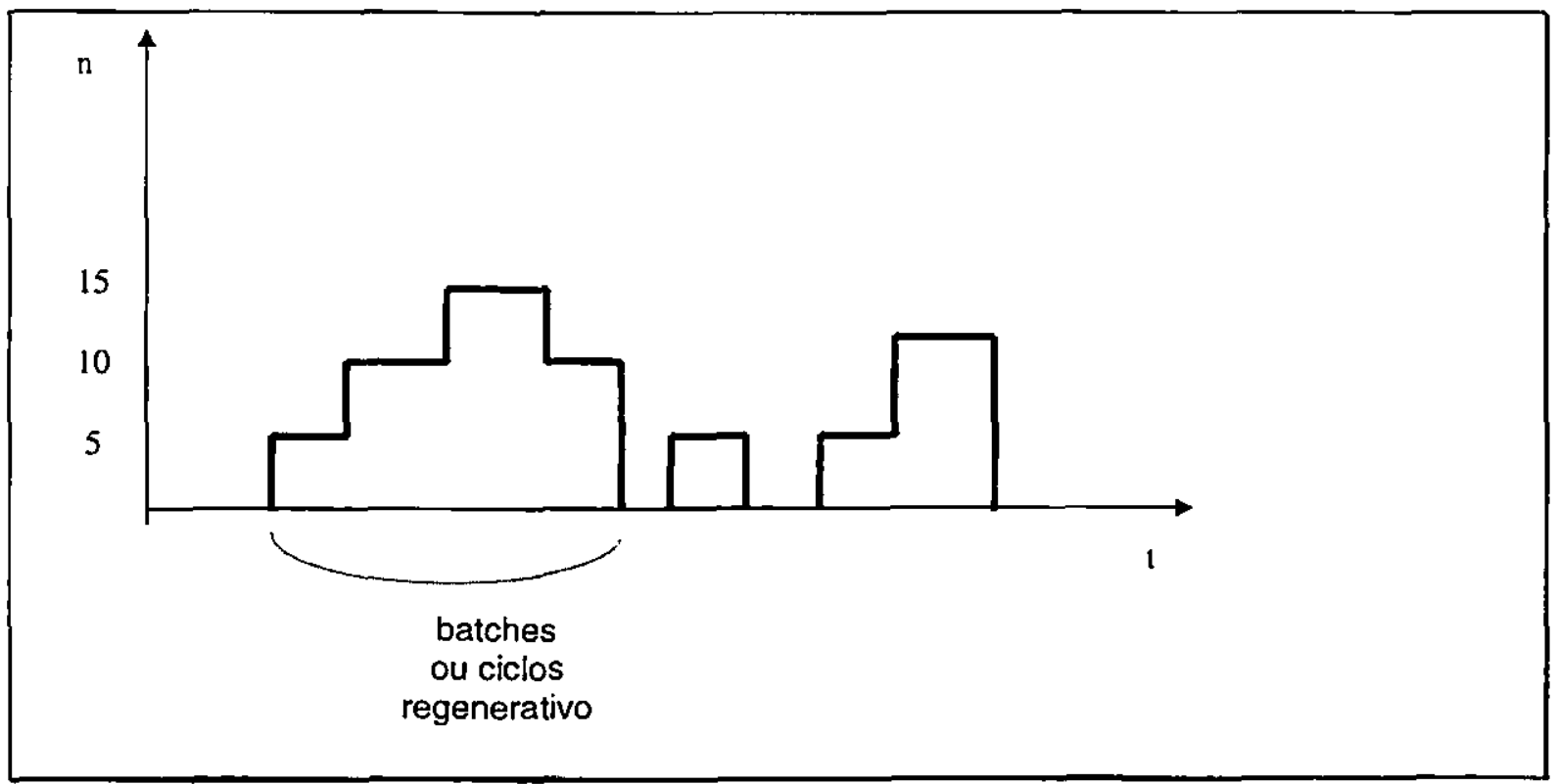

Figura 5.2: Número de clientes pelo tempo num processo regenerativo.

\subsubsection{Método Espectral}

Este método, ao contrário dos anteriores, não exige que as observações sejam independentes e identicamente distribuídas, pois leva em consideração a correlação existente entre elas. Da mesma forma que o método Batch Means e o da Regeneração, utiliza uma única rodada longa de simulação, ao invés de várias curtas, minimizando o tratamento necessário para os efeitos do warm up [SOA92].

Trata-se de um método matematicamente avançado, empregando as transformadas de Fourier. Isto o torna pouco convidativo ao uso [SOA92].

\subsubsection{Métodos de Redução da Variância}

São também conhecidos como técnicas de Monte Carlo e seu objetivo é melhorar a eficiência de uma simulação através da redução da variância entre os valores amostrais [KOB81, MAC87, MIT92, PEG91]. Estão fundamentadas no fato de que a eficiência da simulação melhora conforme diminui o número total de observações necessárias para se atingir uma dada precisão. Mas, quem determina este número de observaçōes é exatamente a maior ou menor variaçāo encontrada entre seus valores. Devido à proporcionalidade existente entre o número de valores amostrais necessários e a variância amostral, estas técnicas visam reduzir a variância e assim, reduzir o número de valores amostrais necessários, melhoram a eficiência da simulação. Não importa qual método de análise de saídas seja utilizado, a semi-amplitude do intervalo de confiança é sempre proporcional ao desvio padrão amostral.

Estas técnicas muitas vezes produzem estimativas bastante precisas utilizando menos valores amostrais que melhoram os métodos tradicionais de análise de saídas e diminuem o tempo gasto na simulação. 
Apesar disso, sua aplicação requer alguma habilidade e não existe um meio de garantir de antemão que sua aplicação realmente reduzirá a variância. Algumas vezes, podem até produzir resultados piores que a análise direta.

As principais técnicas de redução da variância serão apresentadas a seguir:

\section{Números aleatórios Comuns}

Os números aleatórios comuns são utilizados quando se deseja comparar o desempenho de dois ou mais sistemas através da utilização de uma mesma seqüência de números aleatórios para ambos. Este método garante que os sistemas são submetidos às mesmas condições e permite concluir que as possíveis diferenças encontradas entre eles é conseqüência apenas da natureza dos sistemas e não das condições impostas pelo experimento [PEG91, MAC87].

Considerando, por exemplo, dois sistemas $l$ e 2 onde $Y_{l}$ é a média de uma variável aleatória y para o sistema $l$ e $Y_{2}$ é a média da mesma variável aleatória $y$ para o sistema 2 .

Neste caso, o interesse não está no desempenho absoluto dos sistemas, mas sim na diferença relativa entre eles [MIT92] e portanto em $D=Y_{1}-Y_{2}$. A variância de $D$ é dada por:

$$
\operatorname{Var}(D)=\operatorname{Var}\left(Y_{1}\right)+\operatorname{Var}\left(Y_{2}\right)-2 \operatorname{Cov}\left(Y_{1}, Y_{2}\right)
$$

Como o objetivo é reduzir a variância, nota-se que isso pode ser feito quando $\operatorname{Cov}\left(Y_{1}, Y_{2}\right)$ for positiva.

Uma maneira de se fazer isso é exatamente utilizar valores de parâmetros de entrada idênticos para ambas as simulações.

No caso do comportamento dos sistemas ser idêntico (caso trivial) encontra-se $D=0$ e um intervalo de confiança de comprimento zero. Isso demonstrará, com certeza, que não existe diferença entre os sistemas com relação aos parâmetros estudados. Seqüências diferentes de números aleatórios provavelmente produzirão $D \neq 0$ e um comprimento também diferente de zero para o intervalo de confiança.

Nesta técnica, a correlação entre as observações é desejável, porém, ela existe entre as duas seqüências distintas de observações (pares de replicação) mas não entre as observações resultantes (das diferenças entre os pares).

Trata-se de um método bastante utilizado devido à sua simplicidade [PID92], sendo recomendado aos modeladores iniciantes, mas nem sempre há garantia de que sua aplicação efetivamente aumente a eficiência de uma simulação.

Como exemplo real, considere a avaliação da eficiência de dois sistemas de caixa bancário com um servidor cada. Para isso, será produzido para ambos, um mesmo tempo entre chegadas dos clientes cada qual com um determinado tempo de serviço, na mesma seqüência. O comprimento das filas geradas pode ser um bom parâmetro de comparação entre ambos. 


\section{Variáveis de Controle}

A variável de controle é uma variável aleatória correlacionada com uma variável de interesse $y$, cujo valor teórico é conhecido [MAC87, PEG91]. Para a aplicação do método, é necessário identificar a variável de controle apropriada, similar à desejada num modelo mais simplificado, a partir das informações disponíveis sobre o sistema.

Este conhecimento prévio necessário, permite que menos observações sejam extraídas das rodadas de simulação, aumentando sua eficiência [PEG91, MIT92]. A partir do momento em que a variável de controle foi determinada, os valores observados da variável de interesse são corrigidos através dela. Assim, as variáveis de controle têm por objetivo controlar parcialmente as variáveis aleatórias em estudo [PEG91].

É um método muito eficiente para a redução de variância, mas apresenta uma complexidade estatística muito acentuada, 0 que 0 torna pouco recomendável para modeladores iniciantes [MAC87, MIT92]. Outra desvantagem deste método é que implementação é muito específica para o modelo, sendo mais adequado a modelos de simulação de propósito geral como redes de filas [MAC87].

\section{Variáveis Antitéticas}

As variáveis antitéticas visam controlar a variância de um estimador introduzindo uma correlação negativa entre sucessivas simulações de um dado sistema [PID92], diminuindo o número de replicações necessárias para se atingir uma determinada precisão [MAC87].

Suponha que $y$ seja a variável de saída considerada [MAC87], $Y_{\text {, seja a }}$ média referente à primeira replicação e $Y_{2}$ seja a média referente à segunda replicação. Assim: $\bar{Y}=\frac{Y_{1}+Y_{2}}{2}$ e como $Y_{l}$ e $Y_{2}$ são variáveis aleatórias, $\bar{Y}$ também n será.

Então, $\operatorname{Var}(\bar{Y})$ pode ser dada por:

$$
\operatorname{Var}(\bar{Y})=\frac{1}{4}\left[\operatorname{Var}\left(Y_{1}\right)+\operatorname{Var}\left(Y_{2}\right)+2 \operatorname{Cov}\left(Y_{1}, Y_{2}\right)\right.
$$

Então, para que a $\operatorname{Var}(\bar{Y})$ seja reduzida, basta que se tenha $\operatorname{Cov}\left(Y_{l}, Y_{2}\right)<0$. Neste caso, a $\operatorname{Var}(\bar{Y})$ será menor que a obtida no caso de $Y_{1}$ e $Y_{2}$ serem independentes e assim, o número de replicações necessárias também será menor.

Para obter a covariância negativa, existem vários procedimentos, sendo que o mais simples segundo Pidd [PID92] é executar uma rodada de simulação a partir dos números aleatórios antitéticos $u_{1}, u_{2}, u_{3}, \ldots$ e uma outra a partir dos números aleatórios $\left(1-u_{1}\right),\left(1-u_{2}\right),\left(1-u_{3}\right) \ldots$ Esta seqüência aleatória complementar introduz uma correlação negativa entre os resultados das duas simulações [TOC63, PID92] e conseqüentemente, uma covariância negativa. 
Exemplo: Suponha que $y_{1}^{\prime}$ e $y_{2}^{\prime}$ seja o tempo de serviço do i-ésimo cliente nas replicaçōes $l$ e 2 em uma simulação de uma fila $M / M / 1$. Se quando o cliente $i$ tem um tempo longo de serviço na replicação $l$, tiver um tempo de serviço curto na replicação 2 e vice-versa, os tempos de serviço estaräo negativamente correlacionados. Então, se $u$ é uma variável aleatória de estado de $y$ para $y_{1}^{\prime}$, (1-u) será a variável antitética de y para gerar $y_{2}^{\prime}$ [MAC87].

Trata-se de uma técnica que deve ser aplicada com cautela, pois, pode não funcionar em todos os casos a até mesmo aumentar a variância [MAC87] e muitas vezes, a correlação negativa observada pode ser menor que a prevista teoricamente [PID92]. Em sistemas complexos, sua aplicação é bastante difícil, sendo que é pouco provável existir correspondência direta entre os eventos em rodadas sucessivas de simulação [PID92].

\section{Medidas Indiretas}

As medidas indiretas são utilizadas quando é mais eficiente obter uma estimativa indireta da medida de desempenho que tenha uma variância menor que a estimativa direta deste mesmo valor [PEG91]. Segundo MacDougall [MAC87], quando análise do problema requer muitas rodadas, alguma exploração inicial de estimadores alternativos é desejável.

A principal desvantagem deste método é a sua dependência em relaçāo a um particular modelo em contraposição à simplicidade na obtenção de medidas diretas $\theta$ indiretas em uma mesma rodada [PEG91].

\section{Amostragem Seletiva e Descritiva}

Trata-se de um método baseado na obtenção e utilização da inversa da função de distribuição de uma dada variável de interesse. Muitas vezes, é necessário até mesmo uma aproximação numérica. É pouco empregada devido à necessidade de se conhecer de antemão o tamanho da amostra e à inexistência de uma implementação geral do procedimento [PID92].

\subsection{Análise Estatística dos Resultados}

Como já foi visto no início deste capítulo, muitas vezes pode ser necessário efetuar múltiplas medidas de desempenho em um, dois ou mais sistemas. Quando o interesse é obter múltiplas medidas de desempenho $(r)$ de um determinado sistema, determina-se, para cada uma delas, um intervalo de confiança igual a $100(1-\alpha) \%$. Assim, tem-se que, a probabilidade de todos os intervalos conterem simultaneamente suas respectivas médias, é dada pela inequação de Bonferroni:

$$
P \geq I-\sum_{i=1}^{r} \alpha_{i}
$$


Normalmente, a necessidade por múltiplas medidas acarreta em comprimentos de rodadas maiores ou intervalos de confiança mais largos (aumento da semi-amplitude) [MAC87].

Nos casos em que o objetivo é comparar dois sistemas distintos, pode-se estimar o intervalo de confiança para a diferença entre as médias obtidas a partir deles. Isto é, para cada sistema, determina-se a média $Y_{i}$ para um certo número de replicações ou lotes e calcula-se as diferenças entre as médias dos dois sistemas $\left(D_{i}\right)$ e o intervalo de confiança $H_{D}$ para a média $\bar{D}$. Na obtenção dos valores para cada um dos sistemas, pode-se utilizar números aleatórios comuns, conforme visto anteriormente, no sentido de reduzir a variância de $\bar{D}$ e obter um intervalo de confiança mais estreito [MAC87]. A situação se complica quando se deseja comparar mais de dois sistemas, pois muitas vezes, para cada sistema alternativo, existem vários parâmetros a serem avaliados. Neste caso, normalmente é necessário um grande número de rodadas de simulação. Mas, existem métodos bastante eficientes e apropriados para esta finalidade que visam facilitar esta tarefa, bem como diminuir as rodadas de simulação.

\subsection{Comentários Finais}

Um dos principais problemas encontrados ao se fazer uma simulação é determinar o comprimento das rodadas de simulação e o número de rodadas necessário para se atingir uma determinada precisão.

A maioria dos sistemas entra em equilíbrio conforme aumenta o comprimento da rodada, superando desta forma, os efeitos do período de warm up sobre a simulação. Nas simulações do tipo terminante, o período de warm up tem maior influência, uma vez que os resultados iniciais também são considerados. O mesmo não ocorre nas simulações não terminantes, pois neste caso, o interesse está no equilíbrio e não nos resultados iniciais.

As medidas mais comuns de serem tratadas são a média, a variância e o desvio padrão de um determinado parâmetro de um sistema. Mas, estudos mais elaborados podem requerer outras medidas de vários parâmetros de diversos sistemas.

O intervalo de confiança permite delimitar o valor numérico para a média verdadeira de uma variável de interesse através dos resultados de uma simulação, dado um certo nível de confiança. O problema ocorre quando os resultados são correlacionados (e, em geral, o são), pois, neste caso, o intervalo de confiança será subestimado.

Além da correlação, o warm up também desempenha um papel prejudicial para a análise das saídas. Muitos métodos foram apresentados no sentido de compensar a correlação entre os dados amostrais e o problema do warm up: replicações, média dos lotes, regeneração, etc.

Os métodos apresentados, ern geral, necessitam de um grande número de replicações totais, sejam elas, em termos de comprimento de rodada ou em número de rodadas (ou lotes). Isto faz da simulação um processo exaustivo, mesmo para as máquinas atuais de alta velocidade de processamento. Devido a isso, tem-se procurado técnicas que diminuam o número de observações necessárias, garantindo, porém, a precisão e superando os problemas da 
correlação e do warm up. Estas técnicas são conhecidas como técnicas de redução da variância. Algumas delas são: números aleatórios comuns, variáveis de controle, variáveis antitéticas, etc.

Com base nestes métodos, que em geral, aumentam a eficiência e a confiabilidade dos resultados da simulação, será implementado um módulo de análise das saídas para o ASiA, conforme discutido na seção 6.2. 


\section{CAPÍTULO 6}

\section{Avaliação dos Métodos de Análise de Saídas utilizados em Ambientes de Simulação}

\subsection{Introdução}

Nos capítulos anteriores foram discutidos aspectos relacionados à análise de saídas e a pouca atenção dada a este tópico na maioria dos softwares de simulação, apesar de sua incontestável importância. Mesmo assim, muitos softwares de simulação da atualidade oferecem uma vasta gama de aspectos de análise de saídas [BAN96].

A maioria dos autores concordam num ponto: a determinaçāo de um intervalo de confiança para as estatísticas é o mínimo que se pode esperar de um sistema de simulação no que se refere à análise de saídas.

A intenção deste capítulo é apresentar quais aspectos de análise de saídas estão presentes nos principais softwares de simulação, de forma a fornecer a base para o capítulo seguinte, ou seja, a definição do módulo a ser implementado no ASiA.

Além disso, este capítulo apresenta brevemente dois outros métodos para análise de saídas que poderão vir a tomar-se valiosas ferramentas de análise: 0 método Bootstrap e uma técnica heurística utilizada para determinar o comprimento adequado de uma rodada de simulação.

\subsection{Aspectos mais tratados em Análise de Saídas}

Os dados que serão apresentados a seguir procedem de [BAN96] e constituem uma pesquisa sobre os diversos aspectos de análise de saídas e sua disponibilidade nos mais variados produtos de simulação.

A maioria destes aspectos já foi abordada no capítulo 5 , com poucas exceçōes. A tabela 6.1 apresenta alguns dos principais aspectos de análise de saídas, sua descrição e a proporção em que são utilizados nos seguintes softwares: Automod e AutoStat (AutoSimulation, Inc., Bountiful, UT), ARENA (Systems Modeling Corporation, Sewickley, PA), SimStat $\left(\mathrm{MC}^{2}\right.$ Analysis System, Wynantskill, NY), ProModel (PROMODEL Corporation, Orem, UT) e Taylor II (F\&H Simulations, The Netherlands).

Nesta tabela, observa-se na primeira coluna os principais aspectos da análise de saídas implementados, seguido do tipo das variáveis, ou seja, se o aspecto em questāo aplica-se à análise de uma única variável ou de diversas simultaneamente, o método utilizado na abordagem do aspecto, seguido de sua descrição, e a proporção dos sistemas analisados que o implementam. O número que aparece ao lado da proporção, é utilizado para representar o item em questão no gráfico da figura 6.1. Para cálculo destas proporções, levou-se em conta o total de aspectos de análise de saídas considerando todos os softwares analisados. [SWA95]:

Algumas características adicionais destes softwares de simulação são 
- aplicações típicas: os softwares analisados apresentam-se como uma ferramenta de simulação de propósito geral. Automod/AutoStat, porém, enfatiza que é adequada somente para simulação discreta;

- ambiente: quase todos os softwares analisados rodam em ambiente Windows, exceto o Automod/AutoStat, cuja versão baseada em Windows está em desenvolvimento. O ARENA possui versão também para OS/2;

- animação gráfica: quase todos os softwares analisados possuem saídas gráficas animadas que podem ser vistas em tempo real, exceto o SimStat. Automod/AutoStat e Taylorll possuem animação em três dimensões.

Os dados da tabela 6.1 foram transpostos para o gráfico da figura 6.1 de forma a facilitar a visualização. Este gráfico, tem como abscissas os itens assinalados na tabela 6.1 e como ordenadas, as respectivas proporções.

Através deste gráfico, pode-se observar os principais aspectos apresentados pelos softwares de simulação. Considerando a média das proporções, $48.57 \%$ como um delimitador, pode-se verificar que os aspectos mais freqüentes são:

- Método das Replicações para o cálculo do intervalo de confiança para uma única variável ( $100 \%$ dos softwares);

- Método Batch Means (80\%);

- Cálculo do intervalo de confiança para múltiplas variáveis: diversos métodos implementados (80\%);

- Técnicas de Redução da Variância - Números Aleatórios Comuns (80\%);

- Testes de Autocorrelação (80\%);

- Testes de Hipóteses sobre a média de uma única variável $(60 \%)$;

- Método de Welch para a determinação do comprimento do estado transiente $(60 \%)$

- Técnicas de Redução da Variância - Variáveis Antitéticas (60\%);

- Método da Mínima Diferença Significativa de Fisher (60\%).

Com exceção do Método de Welch e do de Fisher, todos os métodos bem cotados nesta pesquisa são também os mais freqüentemente estudados, inclusive neste trabalho de mestrado. No final desta seção, serão apresentadas algumas noções do Método de Welch e do da Diferença Mínima Significativa de Fisher, que não foram considerados no capítulo 5 .

A pesquisa em questão, aborda também aspectos relativos à apresentação dos resultados de uma simulação, tais como, gráficos estatísticos (dados, probabilidades, intervalos de confiança, histogramas), gráficos comerciais (gráficos tipo "pizza", barras, linhas), manipulação de dados (importar e exportar dados), etc. Estes aspectos, porém, não serão tratados neste trabalho.

A tabela 6.3 apresenta uma comparação entre os softwares analisados. Nela, pode-se observar os nomes dos softwares, a proporção de aspectos referentes à análise de saídas e a proporção de aspectos gerais implementados $e$, na última coluna, a média das duas proporções. Estas duas proporções dá uma idéia do quanto cada software é abrangente no que se refere à implementação de aspectos de análise de saídas e na implementação de aspectos gerais. 


\begin{tabular}{|c|c|c|c|c|}
\hline Aspecto & $\begin{array}{l}\text { Tipo das } \\
\text { Variáveis }\end{array}$ & $\begin{array}{l}\text { Método ou } \\
\text { Estatística }\end{array}$ & Descrição & Proporçāo \\
\hline \multirow[t]{3}{*}{$\begin{array}{l}\text { Estatísticas } \\
\text { amostrais }\end{array}$} & & & $\begin{array}{l}\text { N. } .^{9} \text { de observações, valores máximo e } \\
\text { mínimo, média, erro padrăo, etc. }\end{array}$ & \\
\hline & Simples & diversos & Para uma única variável & $40 \%$ (1) \\
\hline & Múltiplas & diversos & Para uma ou mais variáveis & $40 \%{ }^{(2)}$ \\
\hline \multirow[t]{5}{*}{$\begin{array}{l}\text { Teste de } \\
\text { Hipóteses }\end{array}$} & & & $\begin{array}{l}\text { Nível mínimo de confiança necessário para } \\
\text { que uma hipótese não seja rejeitada }\end{array}$ & \\
\hline & Simples & média & Testes sobre a média incluindo: $=,>e<$ & $60 \%^{(3)}$ \\
\hline & & variância & idem sobre a variância & $20 \% \%^{(4)}$ \\
\hline & múltiplas & média & idem & $40 \%(5)$ \\
\hline & & variância & idem & $20 \%$ \\
\hline \multirow[t]{2}{*}{$\begin{array}{l}\text { Período } \\
\text { Translente ou } \\
\text { Warm up }\end{array}$} & ambas & $\begin{array}{l}\text { Método de } \\
\text { Welch }\end{array}$ & $\begin{array}{l}\text { Teste gráfico usando replicações múltiplas } \\
\text { para um dado tamanho de janeia. }\end{array}$ & $60 \%{ }^{(7)}$ \\
\hline & & Autocorrelação & Calcula o relacionamento entre as saidas & $80 \%(8)$ \\
\hline \multirow[t]{8}{*}{$\begin{array}{l}\text { Intervalo de } \\
\text { Confiança }\end{array}$} & Simples & & $\begin{array}{l}\text { Variaçäo na qual se espera encontrar o valor } \\
\text { verdadeiro de um parâmetro com a } \\
\text { probabilidade indicada }\end{array}$ & \\
\hline & & Replicação & $\begin{array}{l}\text { Estima o intervalo de confiança em torno da } \\
\text { média para rodadas independentes de } \\
\text { simulaçắo }\end{array}$ & $100 \%{ }^{(9)}$ \\
\hline & & Batch Means & $\begin{array}{l}\text { Estima o intervalo de confiança em tomo da } \\
\text { média após dividir as observações em lotes } \\
\text { de tamanhos iquais. }\end{array}$ & $80 \%{ }^{(10)}$ \\
\hline & & Regeneração & $\begin{array}{l}\text { Estima o intervalo de confiança em tomo da } \\
\text { média para grupos de dados definidos por } \\
\text { pontos a partir dos quais a simulação parece } \\
\text { iniciar novamente }\end{array}$ & $40 \%{ }^{(11)}$ \\
\hline & & Auto Regressão & $\begin{array}{l}\text { Estima o intervalo de confiança em torno da } \\
\text { média usando o método auto-regressivo }\end{array}$ & $20 \%{ }^{(12)}$ \\
\hline & & Espectral & $\begin{array}{l}\text { Estima o intervalo de confiança em tomo da } \\
\text { média usando o método espectral }\end{array}$ & $20 \%{ }^{(\sqrt{3})}$ \\
\hline & & $\begin{array}{l}\text { Séries de } \\
\text { Tempo }\end{array}$ & $\begin{array}{l}\text { Estima o intervalo de confiança em torno da } \\
\text { média usando o método das séries de tempo }\end{array}$ & $20 \%^{(14)}$ \\
\hline & Múltiplas & idem & $\begin{array}{l}\text { Variação rla qual se espera encontrar a } \\
\text { porcentagem estabelecida de observaçóes } \\
\text { com a confianca indicada }\end{array}$ & $80 \%{ }^{(15)}$ \\
\hline \multirow[t]{3}{*}{$\begin{array}{c}\text { Métodos de } \\
\text { Reduçäo da } \\
\text { Variância }\end{array}$} & & & $\begin{array}{l}\text { Técnicas para cálculo do irtervalo de } \\
\text { confiança que melhoram a eficiência da } \\
\text { simulação }\end{array}$ & \\
\hline & & $\begin{array}{l}\text { Números } \\
\text { Aleatórios } \\
\text { Comuns }\end{array}$ & $\begin{array}{l}\text { Utiliza uma mesma seqũência de números } \\
\text { aleatórios para comparar dois ou mais } \\
\text { sistemas }\end{array}$ & $80 \%^{(16)}$ \\
\hline & & $\begin{array}{l}\text { Variáveis } \\
\text { Antitéticas }\end{array}$ & $\begin{array}{l}\text { Introduz correlação negativa entre os pares } \\
\text { de observaçöes de um dado sistema }\end{array}$ & $60 \%^{(17)}$ \\
\hline $\begin{array}{l}\text { Múltiplas } \\
\text { Comparaçōes }\end{array}$ & & & $\begin{array}{l}\text { Utiliza o método da Mínima Diferença } \\
\text { Significativa de Fisher para determinar } \\
\text { intervalos de confiança em todos os pares } \\
\text { de média }\end{array}$ & $60 \%{ }^{(18)}$ \\
\hline $\begin{array}{c}\text { Seleção do } \\
\text { Melhor }\end{array}$ & & & $\begin{array}{l}\text { Técnica de Múltiplas comparações para } \\
\text { selecionar a melhor de todas as alternativas }\end{array}$ & $20 \%{ }^{(19)}$ \\
\hline \multirow[t]{3}{*}{$\begin{array}{c}\text { Projeto } \\
\text { Experimental }\end{array}$} & & & $\begin{array}{l}\text { Determinação da importância dos valores } \\
\text { solecionados }\end{array}$ & \\
\hline & & One -Way & $\begin{array}{l}\text { Investigação de um fator em níveis } \\
\text { diferentes }\end{array}$ & $40 \%^{(20)}$ \\
\hline & & Factorial & $\begin{array}{l}\text { Dois ou mais fatores são atribuídos a dois } \\
\text { niveis }\end{array}$ & $40 \%^{(21)}$ \\
\hline
\end{tabular}

Tabela 6.1: Principais aspectos de análise de saidas e sua utilização nos softwares de simulação. 
A partir destes dados, conclui-se que o software SIMSTAT pode não ser o mais completo software de simulação, lugar ocupado por Taylor II, mas, com relação à análise de saídas, SIMSTAT ocupa uma posição de destaque.

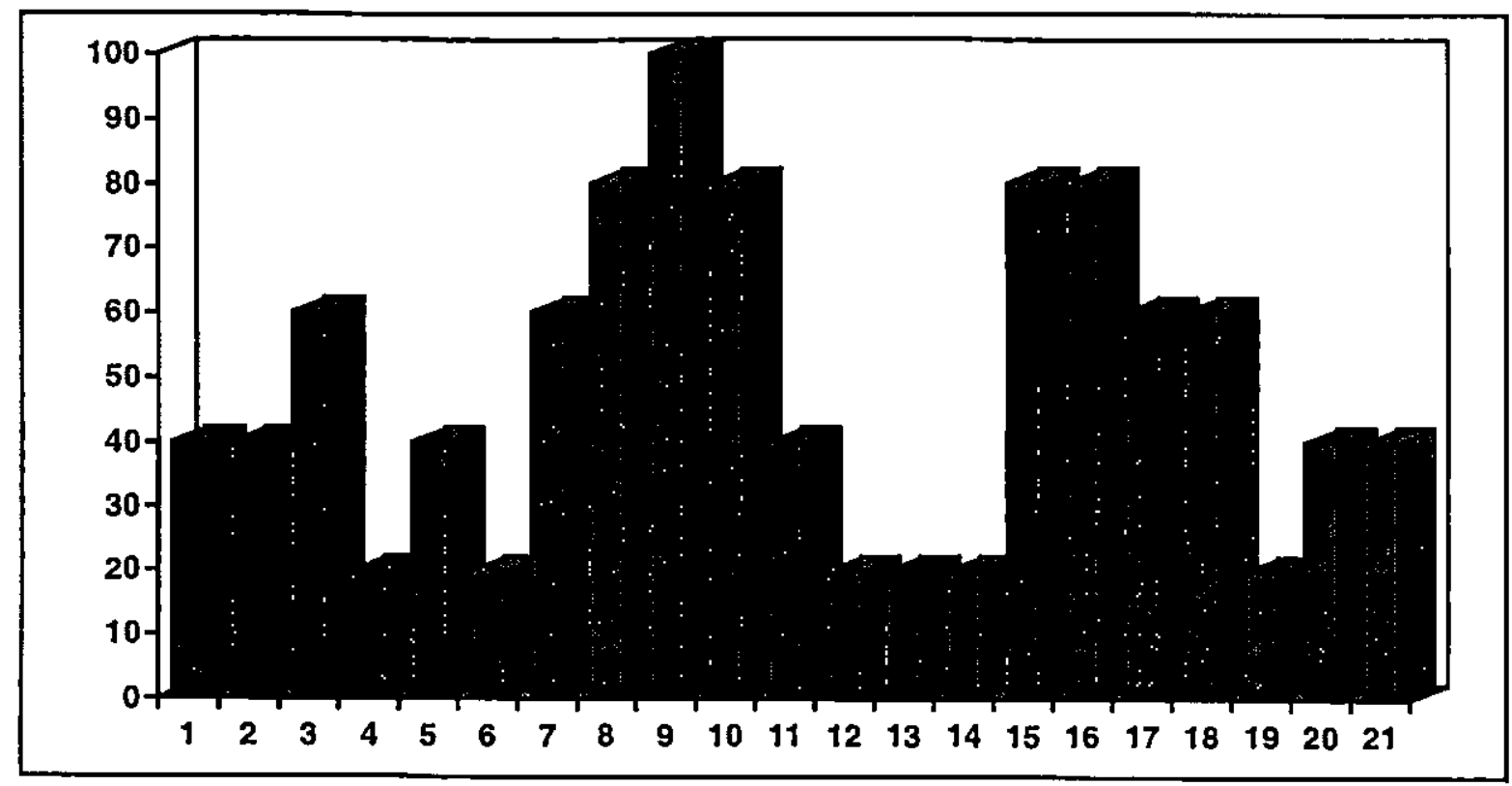

Figura 6.1: Gráfico representativo da tabela 6.1.

\begin{tabular}{|c|c|c|c}
\hline Software & $\begin{array}{c}\text { Proporção de } \\
\text { Aspectos de Análise } \\
\text { de Saídas }\end{array}$ & $\begin{array}{c}\text { Proporção de } \\
\text { Aspectos Gerais, } \\
\text { incluindo gráficos e } \\
\text { gerenciamento de } \\
\text { dados }\end{array}$ & Média Geral \\
\hline Automod/AutoStat & $57.14 \%$ & $53.49 \%$ & $55.32 \%$ \\
\hline ARENA & $38.10 \%$ & $48.84 \%$ & $43.47 \%$ \\
\hline SIMSTAT & $85.71 \%$ & $58.14 \%$ & $71.93 \%$ \\
\hline ProModel & $19.05 \%$ & $27.91 \%$ & $23.48 \%$ \\
\hline Taylor II & $71.43 \%$ & $86.05 \%$ & $78.74 \%$ \\
\hline
\end{tabular}

Tabela 6.2:. Comparação entre as proporções de aspectos apresentados pelos softwares analisados.

Conforme mencionado anteriormente, serão apresentadas agora, algumas idélas básicas do método de Welch e do de Fisher.

- Método de Welch: um grande número de pesquisadores vem sugerindo regras simples para lidar com o problema do warm up, mas a experiência mostra que a eficácia destas regras depende amplamente da natureza dos resultados da simulação. Em conseqüência disto, estas regras são pouco empregadas nas aplicações de simulação [PEG91]. O mais simples, mais prático e provavelmente melhor método para a seleção do ponto de truncamento (ponto a partir do qual os resultados da simulação serão considerados) é a determinação visual, ou seja, selecionando este ponto diretamente do gráfico 
das saídas da simulação pelo tempo. A simples observação pode não ser suficiente para a determinação do ponto de truncamento, pois, em sistemas com grandes variações, a identificação aproximada do instante em que o sistema entra em equilíbrio pode se tornar difícil. Este processo pode ser aperfeiçoado utilizando-se um filtro de movimento médio para suavizar as saídas. Um movirnento médio é construído calculando-se a média aritmética das $K$ mais recentes observações para cada ponto no conjunto de dados. É a escolha do valor apropriado de $K$ quern determinará a maior ou menor suavidade do gráfico das saídas e portanto a possibilidade de se determinar o ponto de truncamento.

- Método da Diferença Mínima de Fisher: trata-se de urn procedimento para determinar diferenças significativas entre comparações múltiplas. Por comparações múltiplas, entende-se, por exemplo, a análise envolvida quando se deseja avaliar dois ou mais sistemas ou projetos alternativos [MAC87], conforme abordado no capítulo 5. Suponha-se dois sisternas $i$ e $j$ cujas médias de uma determinada medida devem ser comparadas. Assim, para o sistema $i$ (e, analogamente, para o sistema $j$ ), obtém-se $n_{i}$ séries (ou replicaçōes) cuja soma de suas médias é $R_{i}$, obtendo-se daí a média das médias das séries $\left(\bar{R}_{i}\right)$ [BYR87]:

$$
\overline{R_{i}}=R_{i} / n_{i}
$$

Este método utiliza o procedimento de Bonferroni (seção 5.4). A mínima diferença significativa entre as séries de médias amostrais $\bar{R}$ e $\bar{R}$, é igual a LSD (Least Significance Difference), onde:

$$
L S D=Z_{\alpha / 2} \sqrt{\frac{n(n+1)}{12}\left(\frac{1}{n_{i}}+\frac{1}{n}\right)}
$$

$s:$ número de comparaçōes $=\frac{k(k-1)}{2}, k=$ número de medidas

Notar que deve-se calcular LSD para todos os pares de medidas, se os tamanhos das amostras forem diferentes. Pode-se encontrar urn valor aproximado para LSD usando a média harmônica dos tarnanhos das amostras, ñ. Então:

$$
L S D=Z \alpha / 2 s \sqrt{\frac{n(n+1)}{6 \tilde{n}}}
$$

Se todos os tamanhos das arnostras forem iguais $\left(n_{i}=n_{j}=n\right)$, então $\tilde{n}=n$

\subsection{Outras técnicas presentes na literatura}

A seguir serão apresentadas duas técnicas de simulação que vêm ganhando importância cada vez maior como ferramenta para análise de resultados. Cada uma tern o seu próprio campo de aplicação, não sendo, portanto, aplicáveis em quaisquer situações. Mas, mesmo assim, estas técnicas 
possuem algumas características em comum, como a facilidade de uso, de compreensão do modelo e a possibilidade de serem utilizadas tanto por especialistas em estatística e simulação como por leigos.

\subsubsection{Técnica Heurística}

Esta técnica foi amplamente discutida em [ROB95] e pode ser utilizada para selecionar um comprimento de rodada adequado para uma simulação nãoterminante em equilíbrio (conforme discutido no capítulo 5), que permita ao usuário confiar na precisão dos resultados obtidos. Foi desenvolvida com a finalidade de ser utilizada tanto por usuários especializados, com algum treinamento em simulação e estatística, como pelos não especializados. Trata-se, portanto, de uma técnica que pode ser automatizada, requerendo baixo nível de conhecimento estatístico, permitindo que usuários com poucos conhecimentos em simulação e estatística possam obter resultados bastante satisfatórios a partir de seus modelos e, principalmente, possam acreditar nestes resultados.

\subsubsection{Descrlção da técnica}

Da mesma forma que as técnicas expostas anteriormente, a técnica heurística inicia-se com a determinação do período de warm up. Isto pode ser feito através dos diversos métodos conhecidos, sendo o Método de Welch, o mais utilizado.

Nesta técnica, uma rodada longa é executada e a medida de interesse é registrada em uma série de tempos para cada observação. A seguir, duas replicações adicionais são executadas e suas medidas são igualmente registradas. Convém lembrar que as observações feitas durante o periodo de warm up são descartadas em todas as replicações. Utilizando as observações de cada rodada $(1,2,3)$ calcula-se a média acumulada principal conforme a fórmula a seguir:

$$
\overline{X_{i j}}=\frac{\sum_{i=1}^{m} x_{i, j}}{i} \text {, onde } i \text { é o número da observação e } j \text { é a rodada }(1,2,3)
$$

As médias assim calculadas, também são representadas em três séries de tempos.

O comprimento da rodada de simulação é, então, selecionado observandose o comportamento destas séries de tempo, ou seja, determinando o ponto no qual as três séries de tempo (que contém as médias acumuladas) tenham convergido suficientemente para dar ao usuário credibilidade suficiente nos resultados encontrados. Como se trata de amostras com a mesma distribuição de probabilidades, é natural que os resultados das três replicações convirjam à medida em que o comprimento da rodada aumenta, pois, quanto maior o tamanho das amostras, maior a probabilidade delas serem similares.

O grau de convergência pode ser considerado usando dois critérios:

- resultados similares: quando o grau de convergência é suficiente para convencer o usuário de que os três resultados são efetivamente os mesmos; 
- diminuição do retorno marginal: quando, aumentando o comprimento da rodada, o nível de convergência, a precisão, melhora apenas marginalmente, e assim, há pouco benefício em executar uma rodada mais longa.

Se os resultados não são convergentes para o comprimento $m$ da rodada, então $m$ deve ser aumentado e o nível de convergência testado até que um resultado satisfatório seja obtido. Para isso, é necessário que as séries de tempo não apenas convirjam, mas que permaneçam convergentes, ou seja, livres de qualquer tendência significativa, nem crescendo e nem decrescendo.

Para cada observação $i$ das três rodadas, pode-se calcular a convergência segundo a fórmula:

$$
C_{i}=\frac{\operatorname{Max}\left(\overline{X_{i 1}}, \overline{X_{i 2}}, \overline{X_{i 3}}\right)-\operatorname{Min}\left(\overline{X_{i 1}}, \overline{X_{i 2}}, \overline{X_{i 3}}\right)}{\operatorname{Min}\left(\overline{X_{i 1}}, \overline{X_{i 2}}, \overline{X_{i 3}}\right)}
$$

onde:

$C_{i}=$ convergência para a observação $i$ das três rodada

$\overline{X_{i j}}=$ média acumulada principal da medida de interesse até a observação $i$ para a rodada $j(j=1,2,3)$.

Uma vez calculada a convergência para cada observação, o próximo passo é decidir sobre qual o nível de convergência aceitável para uma particular aplicação. Como este nível pode ser definido é uma questão inerente ao problema que está sendo analisado $\theta$ à avaliação subjetiva do usuário, podendo envolver a necessidade por um grau significativo de precisão, o custo para a realização dos experimentos, o tempo gasto para obter resultados significativos, etc.

É importante observar que o grau de convergência pode ser obtido com apenas duas rodadas de simulação. A terceira rodada serve para reduzir a probabilidade de erros e assegurar que a convergência realmente ocorreu.

Além disso, pode ser feita uma verificação adicional a partir das distribuições da medida de interesse obtida em cada rodada. Se, para um comprimento de rodada selecionado, estas distribuições forem significativamente diferentes, um comprimento de rodada maior deve ser utilizado, sugerindo que poucas amostras foram obtidas e que aumentando o comprimento da rodada, pode-se alterar a forma das distribuiçōes. Porém, se as distribuiçōes forem relativamente parecidas, isto confirma a escolha de $m$ como um bom comprimento de rodada.

\subsubsection{Algumas Considerações sobre esta técnica}

1) Trata-se de uma técnica retrospectiva, ou seja, o comprimento de rodada inicial deve ser maior que o necessário de forma a poder tirar conclusões sobre os níveis aceitáveis de convergência. Isto pode ser considerado como uma desvantagem, uma vez que consome tempo de experimentação, principalmente 
se o modelo gasta muito tempo para ser executado e as rodadas iniciais forem muito maiores que o necessário. Para solucionar este problema, é utilizada uma regra para estimar o comprimento provável da rodada.

2) Quando múltiplas medidas de interesse estiverem sendo analisadas, o mesmo processo pode ser aplicado, apenas com a variante de que o maior comprimento necessário para que todas elas convirjam seja utilizado.

3) O Intervalo de confiança pode ser calculado através da seguinte fómula:

$$
I C_{i}=\overline{\overline{X_{i}}} \pm t_{2, \alpha / 2} \cdot \frac{S_{i}}{\sqrt{3}}
$$

onde:

$I C_{i}=$ intervalo de confiança até a observação $i$

$\overline{\overline{X_{i}}}=$ média das médias acumuladas principais até a observação $i$

$S_{i}=$ desvio padrão até a observação $i$

$t_{2, \alpha / 2}=$ valor da distribuição de $t$-Student para $n=2$ e nível de significância $\alpha / 2$

$S_{i}=\sqrt{\frac{\sum_{j=1}^{3}\left(\overline{X_{i j}}-\overline{\overline{X_{i}}}\right)^{2}}{2}}$ e $\overline{X_{i j}}$ : média acumulada principal da medida de interesse na observação $i$ da rodada $j$.

\subsubsection{Vantagens e Desvantagens}

A principal vantagem do método recai sobre a facilidade de compreensão e utilização, podendo ser adotado por usuários não especialistas em simulação e/ou estatística. Mas, apesar disto, o usuário deve ser capaz de fazer um julgamento apropriado e consciente no que diz respeito à precisāo desejada, uma vez que o método não fornece uma resposta para o comprimento adequado da rodada, mas sim um meio de saber se o comprimento fornecido inicialmente é suficiente ou não para garantir bons resultados. Além disso, o método também é de fácil implementação e incorporação em softwares de simulação.

Como desvantagem, pode-se citar a principal restrição do método, ou seja, - fato de ser aplicável apenas em simulaçōes não-terminantes e em equilíbrio. Em muitos casos, a própria avaliação subjetiva do usuário costuma ser encarada como uma desvantagem.

\subsubsection{Método Bootstrap}

As técnicas de análise de saídas abordadas neste trabalho (técnicas paramétricas), têm todas uma característica em comum: apoiam-se no Teorema do Limite Central, conforme discutido no capítulo 5, para garantir que os dados sejam independentes e normalmente distribuídos. Esta consideração facilita enormemente o cálculo dos estimadores para as estatísticas verdadeiras. Porém, 
inúmeras vezes, para que esta consideração possa ser feita é necessário a execução de muitas rodadas de simulação, o que nem sempre é uma alternativa viável, devido ao fato de ser a simulação um processo demorado.

Mesmo que seja possível aproximar a distribuição dos dados observados pela normal, problemas tais como: quantas observações deverão ser coletadas, qual o tamanho das rodadas, quantas rodadas serão suficientes, quantos lotes, etc., ainda requerem razoáveis conhecimentos estatísticos e tornam-se um obstáculo para o usuário comum.

O método Bootstrap [FRI95], é uma técnica não-paramétrica de amostragem e reamostragem que não leva em consideração a distribuição de probabilidades dos dados observados. Esta técnica pode ser usada para o cálculo de estimativas para as estatísticas e em testes de hipóteses, podendo ser usado em conjunto com uma variedade de procedimentos estatísticos convencionais.

Assim, este método pode ser aplicado sempre que a distribuição não for conhecida ou for inviável fazer aproximações pela normal, sem precisar recorrer à fórmulas matemáticas ou à derivações.

Trata-se, portanto, de uma nova e poderosa ferramenta para inferências estatísticas, ao mesmo tempo que satisfaz como técnica de análise de saídas de uma simulação, podendo ser facilmente implementada e incorporada a qualquer sistema de simulação.

\subsubsection{Descrição da Técnica}

Nos procedimentos convencionais de inferência estatística e análise das saídas de uma simulação, uma amostra de dados é obtida e uma estatística (por exemplo, a média) é computada. Assumindo que a referida estatística segue uma distribuição conhecida (normal, na maioria das vezes), procura-se estimar um intervalo de confiança para ela e/ou fazer testes de hipóteses [EFR93, FRI95].

No procedimento Bootstrap, uma vez obtida uma amostra tida como confiável, utiliza-se a própria amostra para a construção de uma distribuição de amostragem através da obtenção de reamostras (ou pseudo-amostras) a partir da amostra original, com reposição de elementos. Isto equivale a obtenção de novas amostras a partir de uma população infinita, cujos elementos são exatamente aqueles pertencentes à amostra original, só que um número infinito deles.

Como um exemplo simples deste procedimento, pode-se considerar a seguinte amostra original de 5 elementos, a saber: 1,2 3, 4 e 5 .

A partir desta amostra, obtém-se outras 10 amostras, cada uma delas composta pelos mesmos elementos da amostra original $(1,2,3,4,5)$ escolhidos aleatoriamente com reposição. As amostras adicionais são apresentadas na tabela 6.3. Nesta tabela, pode-se observar o número da amostra e os elementos que a constituem, sendo que todos eles pertencem ao conjunto de valores original.

Após executar este procedimento de reamostragem 200 vezes, obtém-se a tabela de freqüências apresentada na Tabela 6.4 e pode-se construir uma distribuição amostral para a estatística de interesse, seja ela, a média, mediana, variância, percentis, etc. 


\begin{tabular}{|c|ccccc|}
\hline $\begin{array}{c}\text { Número da } \\
\text { Amostra }\end{array}$ & \multicolumn{5}{|c|}{ Composição } \\
\hline 1 & 4 & 5 & 2 & 5 & 5 \\
\hline 2 & 2 & 1 & 5 & 5 & 2 \\
\hline 3 & 5 & 4 & 4 & 1 & 2 \\
\hline 4 & 2 & 5 & 3 & 1 & 2 \\
\hline 5 & 3 & 1 & 1 & 4 & 1 \\
\hline 6 & 1 & 3 & 5 & 3 & 1 \\
\hline 7 & 4 & 3 & 2 & 4 & 5 \\
\hline 8 & 5 & 4 & 4 & 3 & 1 \\
\hline 9 & 5 & 2 & 3 & 3 & 1 \\
\hline 10 & 4 & 2 & 3 & 4 & 5 \\
\hline
\end{tabular}

Tabela 6.3:. Reamostras obtidas a partir da amostra original 1, 2, 3, 4, 5 .

\begin{tabular}{|cc|}
\hline Elementos & Freqüência \\
1 & 150 \\
2 & 355 \\
3 & 298 \\
4 & 171 \\
5 & 26 \\
Total & 1000 \\
\hline
\end{tabular}

Tabela 6.4:. Distribuição de freqüências

A distribuição de amostragem para este exemplo pode ser vista através do gráfico da figura 6.2, onde os valores da amostra constituem o eixo das abscissas e as freqüências obtidas, o eixo das ordenadas.

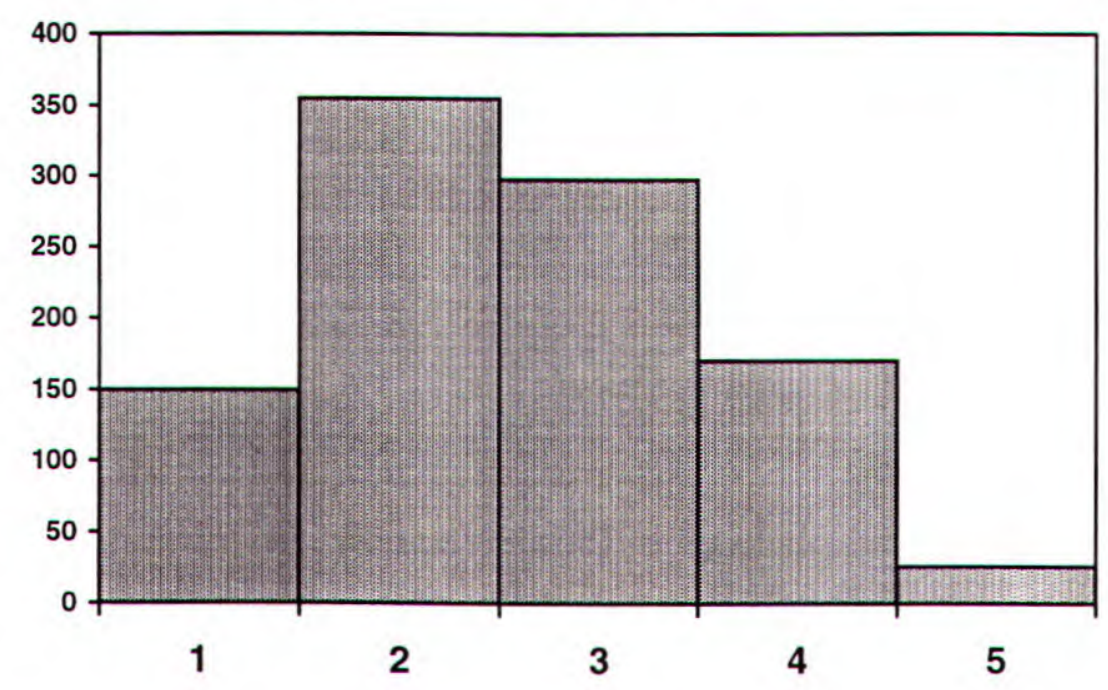

Figura 6.2:. Histograma correspondente à distribuição de freqüências apresentada na tabela 6.4 .

Esta distribuição, baseada apenas na amostra original e não em qualquer distribuição teórica, pode ser utilizada para testes de hipóteses para variáveis de interesse e para a construção de intervalos de confiança. 


\subsubsection{Exemplo}

Considere-se dois sistemas de filas $\mathrm{M} / \mathrm{M} / 1$, sistema I e sistema II, cada qual contendo um único servidor e uma única fila de espera. $O$ tempo médio entre chegadas para o sistema I é de 50 minutos e o tempo médio de serviço é de 30 minutos. Para o sistema II, tem-se tempo médio entre chegadas de 5.56 minutos e tempo médio de serviço de 10 minutos. O sistema foi iniciado no estado de vazio.

Ambos os sistemas foram verificados por 10 seqüências de 30 semanas ( 1 semana $=7 \times 24$ horas). Isto corresponde a 10 replicações independentes de 30 semanas.

A variável de interesse em ambos os sistemas é a mediana dos tempos de espera na fila, ou seja, o valor para o tempo de espera para o qual $50 \%$ dos clientes esperaram menos que este valor e $50 \%$ esperaram mais. As medianas foram calculadas para cada replicação e registradas conforme a tabela 6.5.

A partir da amostra original obtida para o sistema I foram geradas outras 10000 amostras. Calculou-se o intervalo de confiança de $95 \%$ para a mediana verdadeira dos tempos de espera e obteve-se: de 0.207 a 0.251 . O mesmo procedimento foi realizado para o sistema II, obtendo-se o seguinte intervalo de confiança de $95 \%$ : de 0.444 a 0.559 . A tabela 6.6 apresenta os intervalos de confiança obtidos e as correspondentes soluções analíticas conhecidas, neste caso.

\subsubsection{Vantagens e Desvantagens}

O método apresentado tem como vantagens, a facilidade de uso, de compreensão e de implementação, da mesma forma que a técnica Heurística, mas o seu ponto forte é sua utilização em situações onde a distribuição não é conhecida ou não é possível fazer aproximações pela normal.

Sua principal desvantagem é a forte dependência dos resultados em relação à amostra original: se ela consiste em uma boa representação da distribuição, as inferências baseadas na reamostragem de seus elementos serão válidas. Caso contrário, nada se poderá concluir a partir destes resultados.

\begin{tabular}{|c|c|c|}
\hline Replicação & Sistema I & Sistema II \\
\hline 1 & 0.188 & 0.420 \\
\hline 2 & 0.205 & 0.441 \\
\hline 3 & 0.207 & 0.444 \\
\hline 4 & 0.209 & 0.467 \\
\hline 5 & 0.229 & 0.491 \\
\hline 6 & 0.237 & 0.508 \\
\hline 7 & 0.238 & 0.518 \\
\hline 8 & 0.247 & 0.529 \\
\hline 9 & 0.263 & 0.599 \\
\hline 10 & 0.318 & 0.631 \\
\hline
\end{tabular}

\begin{tabular}{|c|c|c|}
\hline Sistema & $\begin{array}{c}\text { Intervalos de } \\
\text { confiança }\end{array}$ & $\begin{array}{c}\text { Solução } \\
\text { Analítica }\end{array}$ \\
\hline I & 0.207 a 0.251 & 0.228 \\
\hline II & 0.444 a 0.559 & 0.490 \\
\hline
\end{tabular}

Tabela 6.6:.Valores obtidos para as medianas em cada sistema e as correspondentes solu çōes analíticas conhecidas.

Tabela 6.5:. Medianas obtidas para os sistemas em cada replicação. 


\subsubsection{Conclusões}

Tanto as técnicas de simulação abordadas no capítulo 5 (passíveis de serem implementadas no ASiA) como outras apenas mencionadas neste trabalho, a saber: Análise Espectral e Método Regenerativo, permitem que se calcule intervalos de confiança, os quais serão utilizados para determinar um comprimento de rodada de simulação satisfatório.

O problema com estas técnicas é a grande quantidade de conhecimentos estatísticos envolvidos, além da freqüente necessidade de manipulação de resultados. Em algumas circunstâncias, torna-se também imprescindível o julgamento subjetivo do usuário. Tudo isso é mais que suficiente para que muitos usuários de simulação das mais diversas áreas sejam incapazes de obter bons resultados de modo a solucionar seus problemas.

A técnica heurística apresentada e o método Bootstrap têm em comum a facilidade de compreensão e implementação e o objetivo de liberar o usuário da aquisição de conhecimentos mais aprofundados em áreas diversas da sua. Ambas apresentam vantagens e desvantagens, as quais foram descritas nesta seção, sendo, cada qual, adequada em diversas situações.

O método Bootstrap tem causado polêmica entre os pesquisadores da área, e em [WOL95] o autor prova que ele é inconsistente com a teoria das probabilidades.

Independente disto, analogamente ao método Bootstrap, outras técnicas não-paramétricas conceitualmente simples, como o estimador Jackknife, por exemplo, vêm sendo de grande utilidade dentro da simulação e estão se tornando cada vez mais populares, apesar de requererem mais tempo para a execução [KLE87].

\subsection{Comentários Finais}

O objetivo deste capítulo foi analisar diferentes softwares de simulação no que se refere à análise estatística dos resultados gerados na simulação. $O$ item 6.2 apresenta os resultados de uma pesquisa visando determinar quais métodos os softwares de simulação realmente implementam.

Assim, foi apresentada uma tabela com 0 intuito de analisar quais softwares são mais completos no tocante aos métodos tradicionais e quais métodos são mais implementados.

$\mathrm{Na}$ pesquisa dos softwares de simulação, foram detectados alguns métodos que não tinham sido abordados, destacando-se o método de Welch e o método da diferença mínima de Fischer. Estes métodos foram analisados neste capítulo.

Observou-se, nesta pesquisa, a presença em todos os softwares de simulação de métodos bastante convencionais, sendo que, nenhum deles apresenta métodos mais recentes para análise de saídas. Apesar disso, existem inúmeros métodos novos e em estudo, que objetivam viabilizar o uso da simulação para um número maior de usuários, através de resultados que possam ser obtidos mais facilmente.

Assim, no final deste capítulo, foram apresentadas duas outras técnicas de simulação (Técnica Heurística e o Método Bootstrap), as quais são técnicas de 
fácil compreensão, permitindo que o usuário se concentre mais no problema a ser analisado do que nos conceitos referentes à estatística ou à simulação, de modo a obter resultados satisfatórios e bastante convincentes conforme o nível de precisão desejado. 


\section{CAPÍTULO 7}

\section{Escolha e Adaptação dos Métodos de Análise de Saídas para o ASiA}

\subsection{Introdução}

O presente capítulo tem a finalidade de detalhar as etapas necessárias para a implementação de um módulo de análise de saídas para o ASiA.

As etapas para a implementação deste módulo, são:

- definição dos métodos estatísticos a serem adotados;

- implementação e análise dos métodos selecionados;

- determinação das alterações a serem efetuadas no ASiA;

- implementação e teste das alterações.

O objetivo deste trabalho é o desenvolvimento das três primeiras etapas definidas no parágrafo anterior.

A definição dos métodos estatísticos a serem adotados está baseada nos resultados da pesquisa apresentada no capítulo 6 , pois, a partir dela chega-se à conclusão que os principais aspectos implementados nos mais conceituados softwares de simulação da atualidade, são também os mais abordados na literatura. Assim, conforme será discutido na seção 7.2, procedeu-se à escolha dos métodos a serem incluídos no módulo de Análise de Saídas do ASiA.

Os métodos selecionados na primeira etapa foram programados e testados, independentemente do ASiA. Os programas desenvolvidos nesta etapa têm a finalidade de demonstrar a aplicação do método para a utilização no módulo de análise de saídas do ASiA. A implementação e teste dos métodos selecionados é discutida na seção 7.3.

$\mathrm{Na}$ terceira etapa, considera-se as alterações necessárias no ASiA para a inclusão dos métodos selecionados na etapa 1 e implementados na etapa 2. Através das implementações efetuadas foi possível determinar as alterações a serem elaboradas tanto no editor gráfico como no gerador de aplicações. O projeto das alterações a serem efetuadas no ASiA é apresentado na seção 7.4.

A etapa 4 , a implementação das modificações estipuladas na etapa 3 , será considerada em trabalhos futuros.

Este capítulo fará referências constantes ao Apêndice $A$, onde poderão ser encontradas as listagens dos códigos-fonte dos programas implementados.

\subsection{Definição do Módulo de Análise de Saídas}

São muitos os aspectos de análise de saídas passíveis de serem implementados. Alguns exigem uma vasta gama de conhecimentos estatísticos, 
enquanto outros, além de serem conceitualmente mais simples, contam com uma enorme quantidade de material bibliográfico de suporte.

A pesquisa apresentada no capítulo anterior dá uma boa visão da variedade de aspectos existentes, embora tenham sido analisados apenas os softwares mais conhecidos.

Para o propósito deste trabalho, apenas alguns aspectos puderam ser selecionados, uma vez que a implementação de todos seria algo impossível, pois, além de existirem muitos e considerar todos ultrapassaria o objetivo desta dissertação, grande parte deles possuem objetivos semelhantes. Cumpre destacar aqui, que uma vez implementados os métodos mais simples e populares, prova-se que é possível a implementação e integração ao ASiA de métodos mais complexos, conforme a necessidade dos futuros usuários.

Para a seleção dos métodos estatísticos a serem utilizados no ASiA, alguns critérios foram adotados:

- possibilidade de automatização: o usuário do ASiA deve ficar o mais longe possivel dos problemas estatísticos;

- desempenho: um problema básico em simulação é o tempo de execução. Desta forma, a seleção dos métodos deve considerar o impacto de sua utilização no tempo de simulação;

- confiabilidade: o objetivo da utilização de um módulo de análise de saída é tornar os resultados da simulação confiáveis. Desta forma, os métodos selecionados deverão estar bem fundamentados na teoria estatística, de modo a permitir o cálculo de resultados segundo uma precisão prédeterminada para um dado nível de confiança;

- facilidade de análise e implementação: implementação de métodos que não dependam de conhecimentos estatísticos muito complexos;

- utilização de métodos comuns a outros softwares de simulação: baseando-se no estudo apresentado no capítulo 6 , procurou-se optar pelos métodos mais utilizados.

Baseando-se nos critérios descritos, os seguintes métodos foram selecionados:

- Método das Replicações para o cálculo do intervalo de confiança de uma única variável;

- Método Batch Means;

- Cálculo do intervalo de confiança para múltiplas variáveis;

- Técnicas de Redução da Variância - Números aleatórios comuns;

- Testes de Autocorrelação, incluído no Método Batch Means.

O Método das Replicações, conforme visto no capítulo 6, é o método mais implementado pelos softwares de simulação (100\% dos softwares utilizam), devido provavelmente à sua simplicidade conceitual.

O Método Batch Means (utilizado por $80 \%$ dos softwares de simulação) também é bastante simples, mas como os resultados de uma única rodada longa são divididos em lotes, o tamanho destes lotes deve ser determinado de modo que não haja autocorrelação entre suas médias. Uma vez determinado o tamanho dos lotes, as estatísticas elementares são aplicadas. 
O cálculo do intervalo de confiança para Múltiplas Variáveis, como visto, é bastante utilizado quando diversas medidas de interesse em um (ou mais) sistema(s) devem ser analisadas conjuntamente (implementado em $80 \%$ dos softwares analisados) . O procedimento, em geral, para implementação, é bem mais complexo.

As técnicas de Redução da Variância, em particular, os Números Aleatórios Comuns, consistem na comparação de dois sistemas submetidos à mesma seqüência de números aleatórios. Trata-se também de um procedimento relativamente complexo.

Finalmente, os testes de Autocorrelação serão implementados em conjunto com o Método Batch Means, para a determinação dos tamanhos dos lotes cujas médias não estejam correlacionadas.

Com relação ao $\mathrm{ASi} A$, os dois primeiros métodos não apresentam problemas. Os testes de Autocorrelação também podem ser implementados sem alterações fundamentais no sistema. Já com relação ao Cálculo do Intervalo de Confiança para múltiplas variáveis, surgem alguns problemas, pois, diversas variáveis deverão ser analisadas ao mesmo tempo e isso poderá requerer mudanças mais significativas em diversos módulos do sistema. Analogamente, a técnica de redução de variância a ser implementada - Números Aleatórios Comuns - , também poderá causar mudanças ainda mais significativas no sistema, uma vez que dois sistemas serão analisados conjuntamente.

Para simplificar o desenvolvimento destes métodos, o Cálculo do Intervalo de Confiança para Múltiplas Variáveis será implementado para um único sistema, ao invés de permitir a comparação de vários. Para comparar vários sistemas, porém, deverá ser utilizado o método dos Números Aleatórios Comuns, mas, para uma única variável. Uma vez implementados estes métodos, mesmo que de uma forma bastante simplificada, a inclusão de uma variada gama de métodos de análise de saídas pode ser implementada e incorporada ao ASiA, independendo de sua complexidade conceitual e sem maiores problemas, uma vez que os passos a serem seguidos já estarão estipulados. O desenvolvimento e a integração de métodos mais complexos poderão ser feitos por pessoal especializado com base na integração feita para os métodos mais simples.

\subsection{Implementação dos Métodos e Exemplos}

\subsubsection{Ambiente de Desenvolvimento}

Os métodos selecionados foram desenvolvidos utilizando-se computadores IBM-PC486 (e mais recentemente, um Pentium) do LaSD (Laboratório de Sistemas Digitais) do ICMSC-USP, o qual é destinado aos alunos do Grupo de Sistemas Distribuídos e Programação Concorrente.

Os programas a serem utilizados no módulo de análise de saídas foram escritos em linguagem $\mathrm{C}$ e compilados através do compilador Borland $\mathrm{C}++$ (Versão 3.1), utilizando-se o Sistema Operacional Windows 95.

A utilização do Compilador Borland $\mathrm{C}++$ (Versão 3.1) deveu-se ao fato de manter a compatibilidade com os outros módulos do ASiA. 
É importante destacar também, a utilização do ambiente de simulação SMPL/PC com todas as funções de biblioteca que formam o subsistema smpl, extensão funcional para simulação, na qual os programas do ASiA são gerados [MAC87]. O desenvolvimento de alguns programas do módulo baseiam-se quase integralmente nos conceitos teóricos expostos em [MAC87].

Outro fator que deve ser destacado é a implementação utilizando a linguagem $\mathrm{C}$ ao invés de $\mathrm{C}++$, apesar de sua importância na atualidade e de suas inúmeras vantagens. Isto deve-se à simplicidade dos programas - todos com muitos cálculos estatísticos, mas pouca interação com 0 usuário -, à homogeneidade do sistema e ao fato de ser a linguagem $C$ bastante conhecida, não só pelos usuários experientes em informática, mas também por pessoas de outras áreas, as quais poderão elas mesmas adicionar outros métodos estatísticos ao módulo.

\subsubsection{Método das Replicações}

O primeiro método implementado foi o das replicações que tem por finalidade determinar automaticamente o número de rodadas necessário para que a média de uma determinada variável de interesse tenha um intervalo de confiança cuja semi-amplitude seja menor ou igual a um valor pré-determinado [MAC87].

O programa que implementa o método das replicações, Repl.c, foi desenvolvido em linguagem $\mathrm{C}$. O programa inicia com um dado comprimento de rodada, baseado nas recomendações anteriormente citadas e, se após um certo número de rodadas, a precisão desejada não for atingida, o usuário é aconselhado a reiniciar a execução do modelo com um valor maior para o tamanho da rodada. O valor aconselhado é o dobro do valor original. Este valor para o tamanho da rodada é empírico, mas, baseia-se nos conceitos abordados no capítulo 5 sobre cobertura do intervalo de confiança.

A análise tem início a partir da chamada do modelo ao método de análise através da função Repl(). O modelo também é responsável pela chamada à função Define_Par_Repl() para alterar os valores padrão dos parâmetros da análise. Num determinado instante dentro do modelo, ocorre a chamada à função Obs_Repl(), cuja finalidade é passar o valor observado da variável para o programa de análise. É importante mencionar que a execução do modelo de simulação está condicionada à uma variável de controle do programa de análise (identificada como $r$ no modelo). Isto significa que o modelo será executado o número de vezes necessário para que o programa de análise tenha o número de observações que ele precisa para atingir o intervalo de confiança desejado.

$O$ procedimento começa com a coleção de 5 rodadas iniciais $(k)$, cada qual com 2500 observações $(m) ; 125$ observações iniciais $(n 0)$ são descartadas em cada rodada para reduzir os efeitos de warm up. Neste ponto, a implementação do método difere um pouco das recomendações: MacDougall sugere que se utilize um comprimento de rodada grande o suficiente para eliminar os efeitos do warm up, ou então que sejam descartadas $5 \%$ das observações iniciais da rodada. O programa Repl.c, também inicia a simulação com um comprimento de rodada grande o suficiente para eliminar os efeitos do warm up, mas permite que (no) observações iniciais sejam descartadas. O valor pré-fixado de no 
corresponde a $5 \%$ do tarnanho da rodada. O objetivo da adoção sirnultânea das duas sugestões é tornar o prograrna o mais genérico possível.

Os valores iniciais de $k, m$ e no (assirn corno diversos outros parâmetros de análise) podern ser alterados pelo usuário através da função Define_Par_Repl().

Quando as primeiras rodadas já tiverem sido colecionadas, suas médias, a média grande e a variância amostral são calculadas, conforme discutido no capítulo 5 .

Como diferentes seqüências de números aleatórios são utilizadas em cada rodada (a cada charnada a $s m p l()$ ou a reset()), as médias das rodadas são independentes $e$ isto exclui a necessidade do cálculo dos coeficientes de autocorrelação.

Repl.c computa, então, a serni-amplitude do intervalo de confiança estimado, baseando-se na variância amostral e no nível de confiança dado e o compara com a semi-amplitude especificada. Se o valor estimado é maior que o valor especificado, a análise termina. Caso contrário, urn novo valor de $k$ é definido, replicações adicionais são executadas, urn novo cálculo do intervalo de confiança é feito e uma nova serni-amplitude é calculada e comparada corn o valor especificado. Segundo [MAC87], a precisão desejada é atingida nesta etapa. Mas, no programa, a coleta de observações continua enquanto a precisão não for alcançada e o número de rodadas não exceder um dado limite. Quando o lirnite é excedido $(k>m x k)$, o prograrna termina informando ao usuário para reiniciar a análise com urn novo comprimento de rodada. Quando o intervalo de confiança desejado tiver sido alcançado, o processo é concluído e os resultados são apresentados.

No início do programa é definida a variável $n x$, corno sendo o número máximo de observações a colecionar. Se ao executar novas rodadas, o valor de $n x$ for excedido, o programa é interrompido e o usuário pode iniciar novarnente corn urn valor maior para $n x$.

As seguintes funções de Repl.c são charnadas externarnente pelo modelo de simulação:

Repl()

Define_Par_Repl():

Obs_Repl():

Obtem_Result_Repl():

Gera_Rel_Repl():

Utilizada para iniciar a análise;

Utilizada para alterar os valores padrão dos parâmetros de análise;

Utilizada para transmitir os valores observados do modelo para o prograrna de análise;

Utilizada pelo modelo para obter os resultados da simulação para gravação ou geração de relatórios específicos;

Utilizada para apresentar os resultados da análise.

Alérn disso, Repl.c utiliza as seguintes funções definidas em Stat.c (arquivo de funções estatísticas em $C$ utilizado pelo smpl):

$Z(p):$

$T(p, q):$

retorna o p-ésimo quantil superior da dlstribuição normal; retorna o p-ésimo quantil da distribuição norrnal com q graus de liberdade. 
O código-fonte deste módulo, bem como os das funções $Z()$ e $T()$ encontram-se no Apêndice A desta dissertação de mestrado.

Exemplo: MacDougall em [MAC87] apresenta um programa representando um modelo de simulação de um sistema de filas $M / M / 1$. Este programa foi alterado, conforme pode ser visto em seguida, para utilizar o método de análise das replicações, através das rotinas desenvolvidas neste trabalho. As alterações no programa principal estão destacadas.

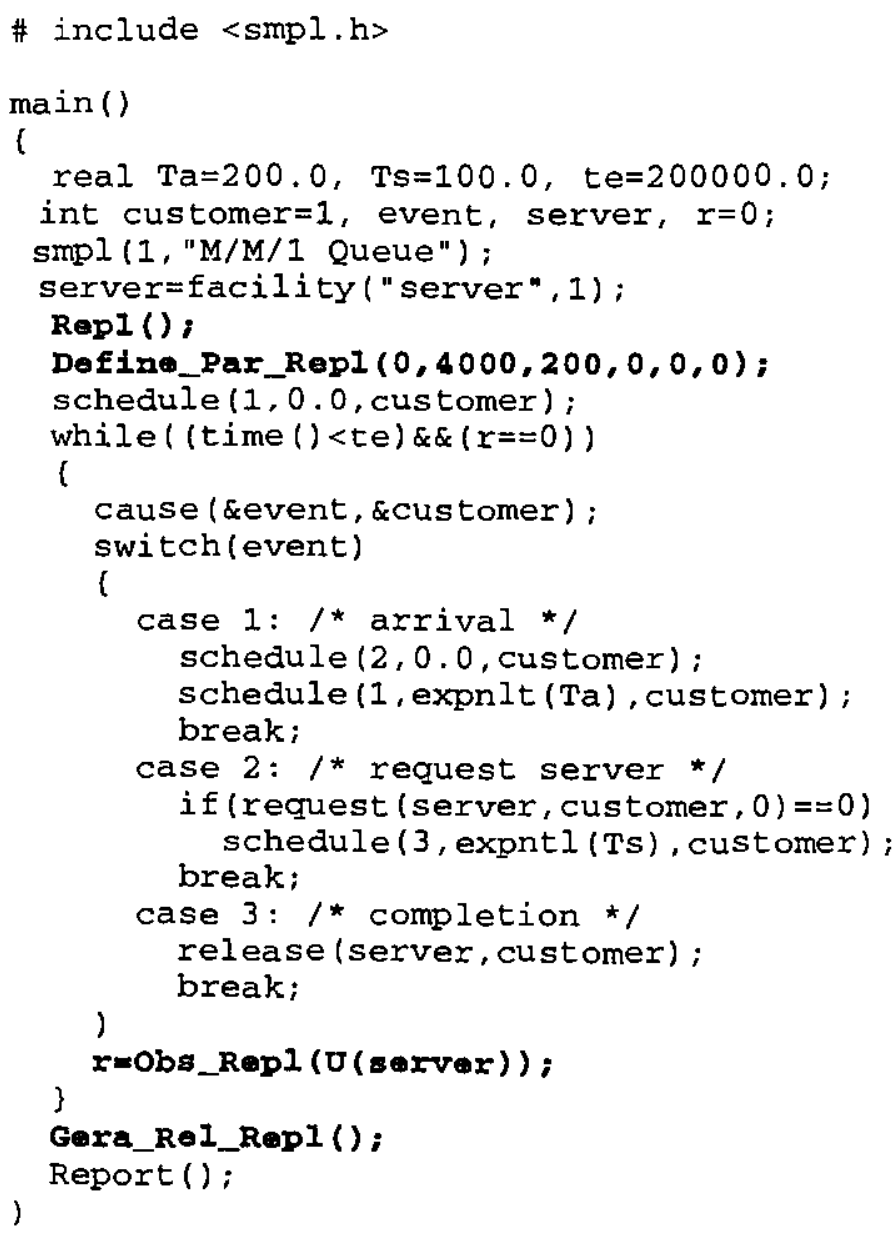

No final da execução do modelo, será emitido inicialmente um relatório contendo os resultados da análise das replicações como o que aparece na figura 7.1 .

Em seguida, será apresentado o relatório padrão do smpl, conforme pode ser observado na figura 7.2.

A tabela 7.1 apresenta os resultados obtidos durante a simulação, ou seja, a média grande calculada após as 5 primeiras rodadas, a variância amostral, a semi-amplitude do intervalo de confiança e a precisão estimada. Uma vez que a semi-amplitude calculada não atingiu a precisão desejada, uma nova rodada foi executada e novos valores foram calculados para as rodadas de 1 a 6 . Finalmente a precisão desejada foi obtida e o processo foi concluído. 


\section{ANALISE DAS SAIDAS DA SIMULACAO \\ MODELO: M/M/I Queue \\ VARIAVEL: U(server) \\ METODO: Replicacoes}

Intervalo de Confianca: $0.463+/-0.043$

Nivel de Confianca ( 8$): 95.0$

Precisao Estimada $(z): \quad 9.2$

Precisao Especificada (8): 10.0

Numero de observacoes iniciais descartadas: 200

Numero total de observacoes: 24000

Comprimento da Rodada: 4000

Numero de Rodadas: 6

Figura 7.1: Relatório das Saídas da Simulação pelo Método das Replicações.

SMPl SIMULATION REPORT

MODEL: M/M/1 Queue

TIME : 200664.157

$\begin{array}{lllll} & & & \text { MEAN } & \\ \text { FACILITY } & \text { UTIL. } & \text { MEAN BUSY } & \text { QUEUE } & \text { OPERATION } \\ \text { server } & 0.5066 & 98.687 & \text { LENGHT } & \text { RELEASE } \\ & & 0.411 & 1030\end{array}$
INTERVAL : 200664.157

server $\quad 0.5066 \quad 98.687$

$0.411 \quad 1030$

COUNT

PREEMPT

0

Figura 7.2: Relatório padrão do smpl para a execução do modelo do exemplo.

\begin{tabular}{|c|c|c|c|c|}
\hline Rodadas & Média Grande & $\begin{array}{l}\text { Variância } \\
\text { Amostral }\end{array}$ & $\begin{array}{c}\text { Semi-Ampitude } \\
\text { do Intervalo de } \\
\text { Confiança }\end{array}$ & $\begin{array}{c}\text { Precisāo } \\
\text { Estimada }\end{array}$ \\
\hline $1-5$ & 0.4648528 & 0.0020105 & 0.0556763 & 0.1197719 \\
\hline $1-6$ & 0.4636985 & 0.0016821 & 0.0430495 & 0.0928395 \\
\hline
\end{tabular}

Tabela 7.1: Tabela apresentando valores obtidos durante a simulaçāo.

É importante salientar que nesta implementação do método das replicações, qualquer variável poderia ser a variável de interesse para a análise. Isto requer apenas que sua fórmula de cálculo seja inserida adequadamente dentro do modelo e seu valor seja transferido para o método de análise utilizando a função Obs_Repl(). Neste exemplo, utilizou-se a função $U()$ do smpl pelo fato dela ser pré-definida.

\subsubsection{Método Batch Means}

A implementação desenvolvida para o método Batch Means neste trabalho, está baseada nos procedimentos descritos em [ADA83]. Estes procedimentos também deram origem a uma versão deste método apresentada 
detalhadamente em [MAC87] e referenciada como Bma.c. A versão desenvolvida nesta tese de mestrado utiliza as estruturas e a lógica encontrada em [MAC87] mas com muitas adaptações e simplificaçōes.

O programa desenvolvido em linguagem $\mathrm{C}$ que implementa o método Batch Means (referenciado aqui também como Bma.c) tem por finalidade determinar automaticamente o comprimento da rodada de simulação necessário e suficiente para estimar o valor de uma variável de interesse com um determinado nível de confiança.

Como no método anterior, a análise tem início a partir da chamada do modelo ao método de análise através da função $B m a()$, causando a inicialização dos totalizadores dos lotes.

O programa de análise inicializa diversos parâmetros com valores padrāo. Através do modelo de simulação, o usuário pode alterar estes valores através da função Define_Par_Bm que será posteriormente descrita.

Em um determinado instante, dentro da execução do modelo, ocorre a chamada à função Obs_Bma(), que é a responsável por transferir o valor da variável de interesse para o módulo de análise. A partir deste instante, inicia-se propriamente a análise com a coleção de $n b$ lotes cada qual com bs observações da variável de interesse. Antes disso, porém, ocorre a eliminação de no valores iniciais, para evitar problemas de warm up. Assim que os lotes estiverem completos, suas médias, a média grande e a variância amostral são calculadas.

Devido ao fato de os lotes serem significativamente menores que as rodadas do método das replicações, para garantir a independência entre suas médias é necessário calcular suas autocorrelações. Assim, as autocorrelações das médias dos lotes são calculadas e avaliadas conforme um nível préespecificado de significância e, se alguma delas for significativa, o tamanho dos lotes é dobrado, lotes adicionais são colecionados e novos testes de autocorrelação são efetuados até que a hipótese de independência seja satisfeita.

A análise é dividida em fases para melhor compreensão: fase 0 : inicial; fase 1: determinaçāo do tamanho do lote; fase 2: determinação do número de lotes; fase 3: final.

O processo de determinação da semi-amplitude do intervalo de confiança é o mesmo descrito no procedimento para o método Batch Means exposto no capítulo 5: o número de lotes é incrementado até que se encontre a precisão desejada. No programa de análise, um cuidado especial deve ser tomado para que o número máximo de lotes não seja excedido conforme novos lotes sejam colecionados. Caso isso ocorra, um outro procedimento entra em ação, dobrando o tamanho dos lotes e dividindo por dois o número de lotes. Quando, porém, o número máximo de observações é excedido, o programa pára e informa ao usuário que ele deve reexecutá-lo com um número de observações maior.

Finalmente, quando o intervalo de confiança desejado é alcançado, um outro procedimento é iniciado. Trata-se de um processo para melhorar a probabilidade de cobertura da média para o intervalo de confiança, reduzindo o número de lotes para no máximo 30 . Para isso, o número de lotes é dividido por dois e o tamanho do lote é dobrado e um novo intervalo de confiança é calculado e comparado com o especificado. Este processo continua até que a semiamplitude requerida seja obtida para no máximo 30 lotes. 
As principais funções do módulo Batch Means que podem ser acessadas externamente são:

Bma():

Define_Par_Bm():

Obs_Bma():

Obtem_Result_Bm();

Gera_Rel_Bm(): inicia a análise a partir do modelo de simulação e zera totalizadores;

permite alterar os valores padrão a partir do modelo de simulação;

transfere os valores observados do modelo de simulação para o programa de análise;

Utilizado pelo modelo para obter resultados da simulação para gravação ou geração de relatórios específicos;

apresenta o relatório Batch Means.

Além destas, o módulo de análise Batch Means também utiliza as funções globais $Z(p)$ e $T(p)$, já explicadas anteriormente.

O código-fonte deste módulo encontra-se no apêndice A desta dissertação.

Exemplo: O mesmo programa apresentado na seção anterior é mostrado a seguir com as alterações para a chamada ao método de análise Batch Means. Neste caso deseja-se efetuar a simulação com 10 lotes iniciais, cada qual com 80 observações, sendo que as 20 primeiras são descartadas.

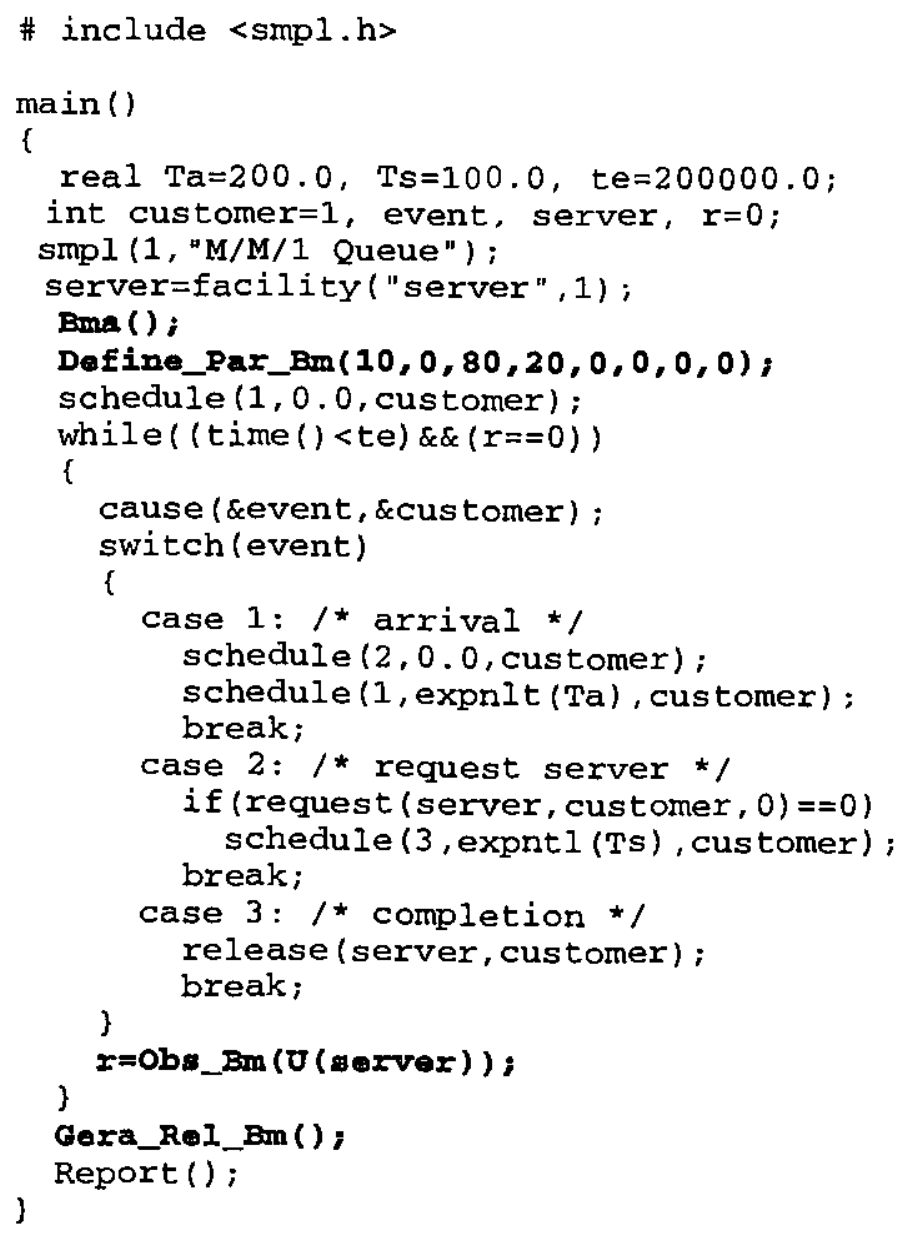


No final da execução do modelo, será apresentado o relatório da análise Batch Means, como mostra a figura 7.3.

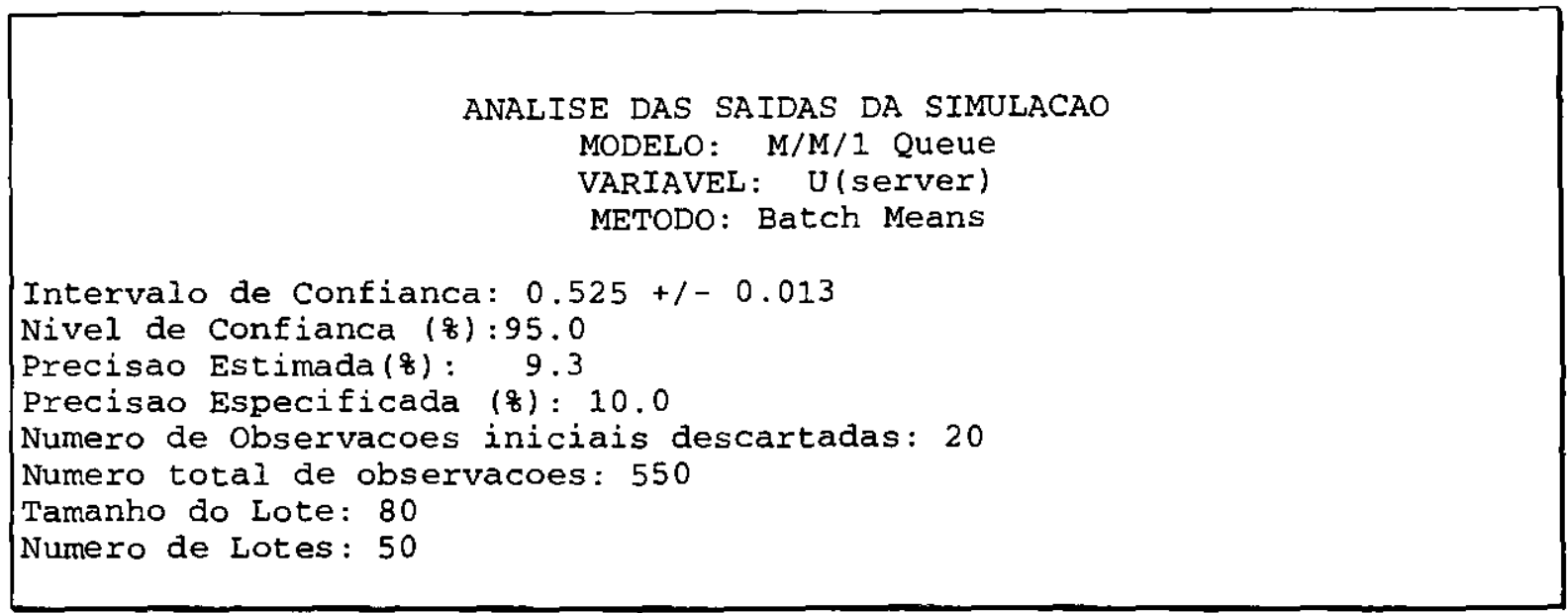

Figura 7.3: Relatório das Saídas da Simulação pelo Método Batch Means.

Em seguida, será apresentado o relatório padrão do smpl, conforme pode ser observado na figura 7.4 .

Smpl SIMULATION REPORT

MODEL : M/M/1 Queue

TIME : 27696.604

$\begin{array}{lllll} & & & \text { MEAN } & \\ \text { FACILITY } & \text { UTIL. } & \text { MEAN BUSY } & \text { QUEUE } & \text { OPERATION } \\ \text { server } & 0.6066 & 108.395 & \text { LENGHT } & \text { RELEASE } \\ & & 0.773 & 155\end{array}$
INTERVAL: 27696.604

COUNT
PREEMPT
0

Figura 7.4: Relatório padrão do smpl para a execução do modelo do exemplo.

A tabela 7.2 apresenta os resultados obtidos durante a simulação, ou seja, a média grande calculada após os 10 primeiros lotes, a variância amostral, a semi-amplitude do intervalo de confiança, a precisão estimada e o tamanho do lote. Uma vez que a semi-amplitude calculada não atingiu a precisāo desejada, um novo lote foi obtido e novos valores foram calculados para as estimativas. Com a obtenção do $11^{\circ}$ lote, a precisão desejada foi obtida e o processo, concluído.

\begin{tabular}{|c|c|c|c|c|c|}
\hline Lotes & Média Grande & $\begin{array}{c}\text { Variância } \\
\text { Amostral }\end{array}$ & $\begin{array}{c}\text { Semi-Ampitude } \\
\text { do Intervalo de } \\
\text { Conflança }\end{array}$ & $\begin{array}{c}\text { Precisão } \\
\text { Estimada }\end{array}$ & $\begin{array}{c}\text { Tam. } \\
\text { dos } \\
\text { lotes }\end{array}$ \\
\hline $1-10$ & 0.6098528 & 0.0083165 & 0.0652541 & 0.1036614 & 50 \\
\hline $1-11$ & 0.5936985 & 0.0076044 & 0.0585991 & 0.0935794 & 50 \\
\hline
\end{tabular}

Tabela 7.2: Tabela apresentando valores obtidos durante a simulação.

De maneira análoga ao exemplo apresentado na seção anterior, optou-se por utilizar uma função pré-definida do smpl - $U()$ - ao invés de definir uma dentro 
do modelo de simulação. Este procedimento também será adotado quando estes módulos forem adaptados ao ASiA.

\subsubsection{Cálculo do Intervalo de Confiança para Múltiplas Variáveis}

Conforme tem sido amplamente abordado na literatura, este tópico pode ser visto de duas maneiras. A primeira delas consiste em analisar diversas medidas de uma mesma facility a partir de um único modelo de simulação, segundo algum método de análise. A segunda, consiste em fixar uma variável de interesse e compará-la através da execução de diversos modelos. Esta análise é a própria avaliação de desempenho, limitada, no entanto à observação de uma única variável.

Para o primeiro caso, foram alterados os programas do método das replicações e do Batch Means, bem como alguns aspectos relevantes do ASiA. Para o segundo caso, é apresentado um algoritmo geral explicando a lógica do processo e a integração ao $\mathrm{ASi} A$, abrangendo porém, a comparação entre dois sistemas.

\subsubsection{Variáveis Múltiplas para a simulação de um único modelo}

Para implementar este método de análise, foi necessário criar dois outros programas: o primeiro deles, similar ao desenvolvido para o método das replicações implementado, denominado RepIMV.c e o outro, similar ao método Batch Means, denominado BmaMV.c. Estes nomes foram escolhidos numa tentativa de manter uma certa padronização.

Ambos os programas funcionam de maneira análoga aos programas originais. A única diferença é a coleta de três variáveis de análise ao invés de apenas uma.

Para os três conjuntos de valores observados são calculadas as suas médias, variâncias amostrais e semi-amplitudes. O procedimento pára quando se atinge a precisão desejada para as três medidas simultaneamente.

Um fato relevante neste método é a relação que o nível de confiança total especificado para as três medidas têm para com os níveis de confiança individuais. Se o nível de confiança total desejado for de $95 \%$, então ( $\alpha=1-0.95=0.05$ ), deve-se ter $\Sigma \alpha_{i}=0.05$. Por exemplo, pode-se ter $\alpha_{U}=0.02, \alpha_{B}=0.02$ e $\alpha_{L q}=0.01$, e daí, os níveis de confiança individuais desejados seriam, respectivamente, $98 \%, 98 \%$ e $99 \%$. Conforme discutido no capítulo 5, deve-se ter

A chamada aos programas deste método também ocorre de maneira similar. A única diferença ocorre nas funções $O b s_{-}$Repl_MV e Obs_Bm_MV, as quais devem passar três parâmetros ao invés de um único.

As variáveis de interesse que podem ser analisadas por este método também restringem-se às mesmas dos métodos anteriores, ou seja, $U(f), B(f)$ e $L q(f)$, por razões já citadas.

Os códigos-fonte de ReplMV.c e BmaMV.c encontram-se também no Apêndice A desta dissertação.

As seguintes funções de ReplMV.c são chamadas externamente pelo modelo de simulação: 
RepIMV()

Define_Par_RMV():

Obs_Repl_MV():

Obtem_Result_RMV(): Utilizada para transferir os resultados da análise para

Gera_Rel_RMV():

utilizada para iniciar a análise;

utilizada para alterar os valores padrão dos parâmetros de análise;

utilizada para transmitir os valores observados do modelo para o programa de análise;

o modelo;

utilizada para apresentar os resultados da análise.

Analogamente aos métodos anteriores, este método também utiliza as funções globais $Z(p)$ e $T(p)$ explicadas anteriormente.

O código-fonte deste módulo encontra-se no apêndice A desta dissertação.

Exemplo: O modelo analisado nos outros exemplos foi alterado para utilizar o método de análise das replicações para múltiplas variáveis, através das rotinas desenvolvidas neste trabalho. As alteraçōes no programa original estão destacadas.

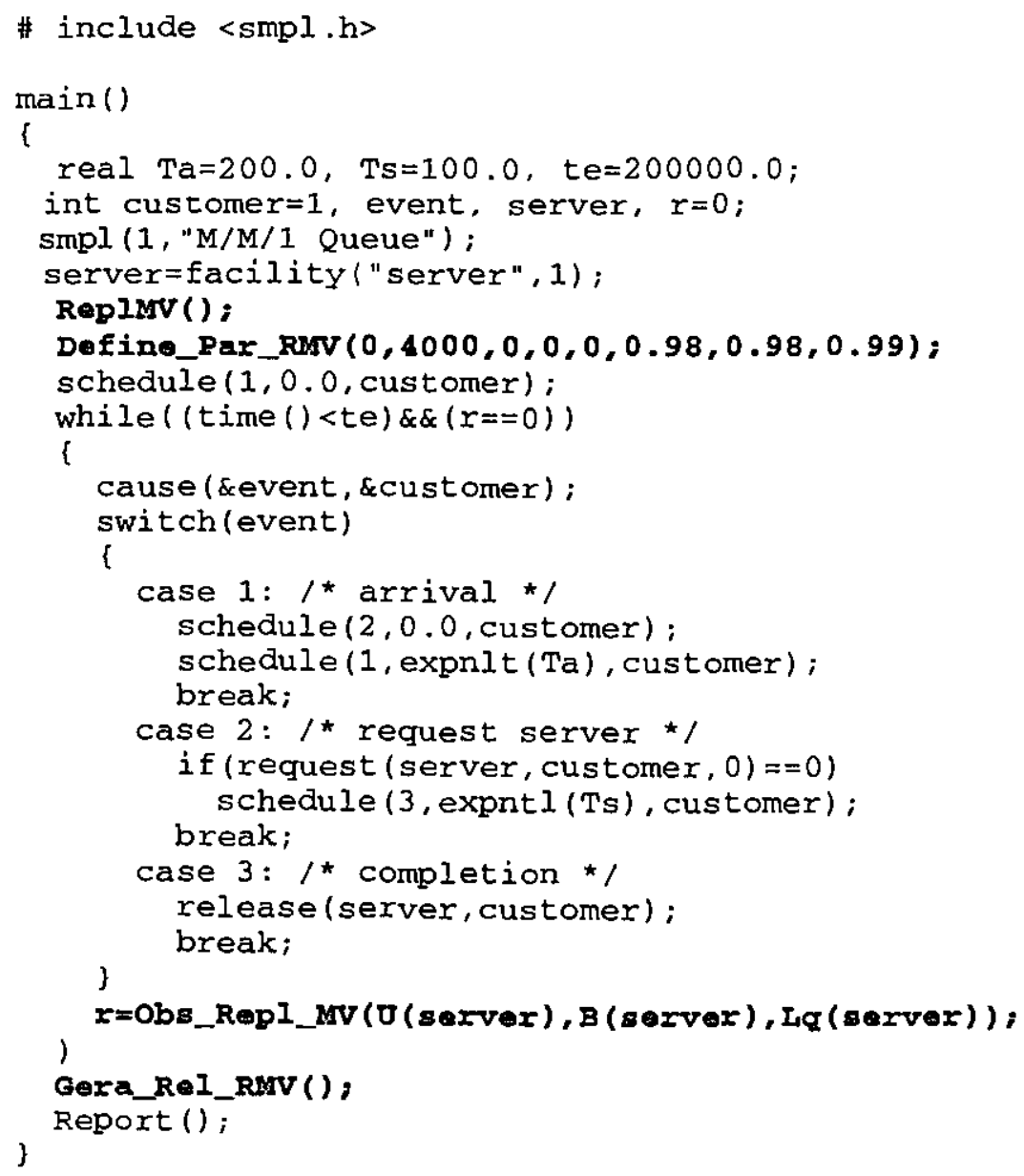

No final da execuçāo do modelo, será emitido inicialmente um relatório contendo os resultados da análise das replicações como o que aparece na figura 7.5 . 


\section{ANALISE DAS SAIDAS DA SIMULACAO \\ MODELO: M/M/1 Queue \\ VARIAVEL: Múltiplas Variáveis \\ METODO: Replicacoes}

Numero de Rodadas: 72

Comprimento da Rodada: 4000

Numero total de observacoes: 288000

Numero de Observacoes iniciais descartadas: 200

Intervalo de Confianca para U():0.5007+/-0.0083

Nível de Confianca (\%):98.0

Intervalo de Confianca para $B(): 100.2345+1-0.9993$

Nível de Confianca (*):98.0

Intervalo de Confianca para $\mathrm{Lq}(): 0.5173+/-0.0536$

Nível de Confianca (\%):99.0

Nivel de Confianca total (8):95.0

Precisao Especificada (\%): 10.0

Figura 7.5: Relatório das Saídas da Simulação para Múltiplas Variáveis (Método das Réplicaçōes).

Em seguida, será apresentado o relatório padrão do smpl, conforme pode ser observado na figura 7.6.

Analogamente ao método das replicações, o programa desenvolvido neste trabalho que implementa o método Batch Means também foi adaptado para analisar múltiplas variáveis. Trata-se do programa BmaMV.c conforme destacado no início desta seção.

SMPI SIMULATION REPORT

MODEL: M/M/1 Queue

TIME : 217125.586

\begin{tabular}{|c|c|c|c|c|c|c|}
\hline \multirow{4}{*}{$\begin{array}{l}\text { FACILITY } \\
\text { server }\end{array}$} & \multirow{4}{*}{$\begin{array}{l}\text { UTIL. } \\
0.5367\end{array}$} & \multirow{4}{*}{$\begin{array}{l}\text { MEAN BUSY } \\
\text { PERIOD } \\
103.409\end{array}$} & \multirow{4}{*}{$\begin{array}{l}\text { MEAN } \\
\text { QUEUE } \\
\text { LENGHT } \\
0.520\end{array}$} & \multicolumn{2}{|c|}{ INTERVAL : } & \multirow[t]{2}{*}{586} \\
\hline & & & & RELEASE & COUNT & \\
\hline & & & & 1127 & PREEMPT & QUEUE \\
\hline & & & & & & 618 \\
\hline
\end{tabular}

Figura 7.6: Relatório padrão do smpl para a execução do modelo do exemplo.

As seguintes funções de BmaMV.c sāo chamadas externamente pelo modelo de simulação:

BmaMV():
Define_Par_BMV():

Obs_Bm_MV():

Obtem_Result_BMV():

Gera_Rel_BMV(): utilizada para iniciar a análise;

utilizada para alterar os valores padrão dos parâmetros de análise;

utilizada para transmitir os valores observados do modelo para o programa de análise;

utilizada para transferir os resultados da análise para o modelo para gravação ou geração de relatórios específicos;

utilizada para apresentar os resultados da análise. 
Este programa também utiliza as funçōes estatísticas $Z(p)$ e $T(p)$. $O$ código-fonte deste programa e destas funções estatísticas encontram-se no Apêndice $A$ desta dissertação.

Exemplo: O modelo analisado nos exemplos anteriores é novamente utilizado para exemplificar agora o método de análise Batch Means para múltiplas variáveis. Analogamente ao exemplo anterior considera-se um nivel de confiança total de $95 \%$. Para isso estipula-se, para os níveis de confiança individuais, os seguintes valores: $98 \%$ para $U(), 98 \%$ para $B()$ e $99 \%$ para $L q()$. As alterações no programa original correspondentes às chamadas às funções do módulo de análise aparecem destacadas.

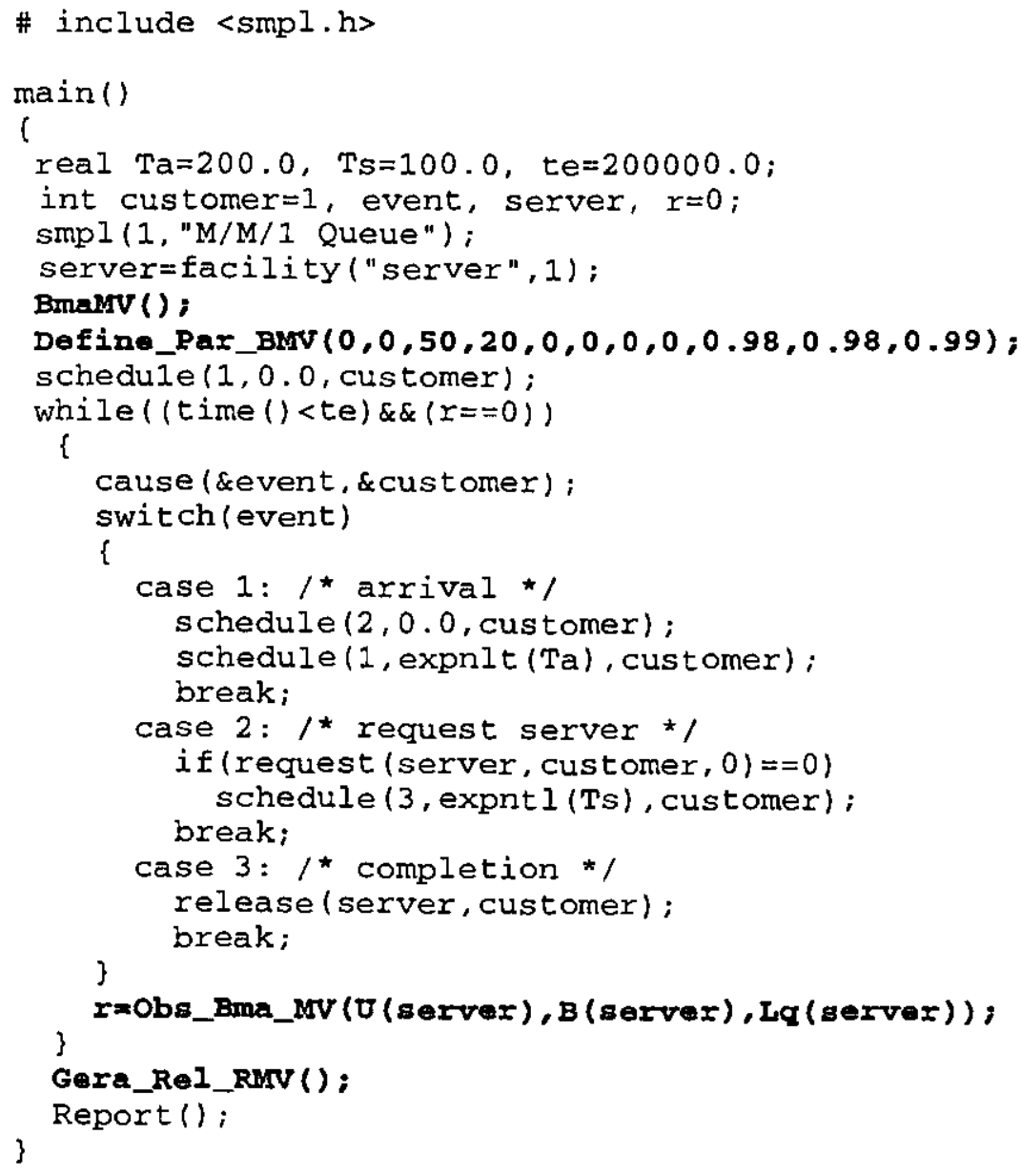

No final da execução do modelo, será emitido inicialmente um relatório contendo os resultados da análise das replicações como o que aparece na figura 7.7. Em seguida, será apresentado o relatório padrão do smpl, conforme pode ser observado na figura 7.8 . 


\section{ANALISE DAS SAIDAS DA SIMULACAO \\ MODELO: $M / M / 1$ Queue \\ VARIAVEL: Múltiplas Variáveis \\ METODO: Batch Means}

Numero de lotes: 38

Tamanho do lote: 50

Numero total de observacoes: 1900

Numero de Observacoes iniciais descartadas: 10

Nivel de Confianca Total (z):95.0

Precisao Especificada (\%): 10.0

Intervalo de Confianca para U():0.558+/-0.0350

Nível de Confianca (\%):98.0

Intervalo de Confianca para $B(): 108.926+/-5.6311$

Nível de Confianca (\%):98.0

Intervalo de Confianca para $\operatorname{Lg}(): 0.672+/-0.0130$

Nível de Confianca (8):99.0

Figura 7.7: Relatório das Saídas da Simulação para Múltiplas Variáveis. (Método Batch Means).

\section{smpl SIMULATION REPORT}

MODEL: M/M/1 Queue

$\begin{array}{llll} & & & \text { MEAN } \\ \text { FACILITY } & \text { UTIL. } & \text { MEAN BUSY } & \text { QUEUE } \\ \text { server } & 0.5069 & 98.072 & \text { LENGHT } \\ & & \end{array}$

TIME : 105053.036

INTERVAL: 105053.036

\begin{tabular}{ll}
\multicolumn{1}{c}{ OPERATION } & \\
RELEASE & COUNT \\
543 & PREEMPT \\
& 0
\end{tabular}

QUEUE 280

Figura 7.8: Relatório padrāo do smpl para a execuçāo do modelo do exempio.

7.3.4.2 Comparação entre dois sistemas utilizando técnicas de redução de Variância

Como mencionado anteriormente, esta análise pode ser vista como um método simples para avaliação de desempenho entre dois sistemas de filas.

Ele difere dos métodos anteriormente descritos pelo fato de que, quando ativado, os modelos de simulação já devem estar prontos e com os resultados da análise armazenados em alguma estrutura de dados a que o método possa ter acesso. Resta, então, ao programa de análise, apenas comparar os resultados obtidos dos modelos em evidência.

A seguir, é apresentada a seqüência de passos que o programa de comparação deve obedecer:

10 Passo: Obtenção dos modelos que devem ser comparados.

Verifica se os modelos em questão (referenciados como 1 e 2) estão prontos e se já foram executados. Verifica também se em ambos os casos foram utilizadas a mesma seqüência de números aleatórios, para que possa ser 
aplicada a técnica de redução de variância denominada Números Aleatórios comuns, descrita no capítulo 5 desta dissertação.

2 Passo: Consistência dos valores e métodos.

Verifica se a mesma variável foi analisada em ambos os modelos, para a mesma facility e para o mesmo método de análise.

3 Passo: Cálculo da Diferença entre as médias.

Calcula $D_{i}=Y_{1 i}-Y_{2 i}$, onde $i$ é o i-ésimo lote ou rodada de cada sistema. Calcula $\bar{D}, s^{2}$ e $H_{D}$.

4ํ Passo: Apresentação dos resultados.

Informa ao usuário os valores calculados no passo anterior.

No apêndice A desta dissertação encontra-se o código fonte do programa Compara.c, responsável pela implementação deste método. Este programa, não utiliza funções como os demais programas, exceto a função estatística $T($ ).

Exemplo: $O$ exemplo apresentado nas seções anteriores também foi utilizado para ilustrar este método. Neste caso, é necessário, porém, dois modelos de simulação. O primeiro, será mesmo que o exemplo anterior, sem qualquer alteração. O segundo será o mesmo modelo, mas com os valores de $T a=100.0 \mathrm{e}$ $T s=100.0$. O objetivo desta comparação é estimar um intervalo de confiança para a diferença entre as duas médias. A variável de interesse será a mesma dos exemplos anteriores, a Utilização Média do servidor. Após a execução do programa, obteve-se os resultados para as médias apresentados na tabela 7.3.

\begin{tabular}{|c|c|c|}
\hline Modelo 1 & Modelo 2 & Diferença entre as médias \\
\hline 0.53057911 & 0.93294262 & -0.4023647 \\
\hline 0.51960849 & 0.94941709 & -0.4298086 \\
\hline 0.46111924 & 0.98610174 & -0.5249825 \\
\hline 0.49528483 & 0.90428806 & -0.4090032 \\
\hline 0.48327351 & 0.95537012 & -0.4720966 \\
\hline
\end{tabular}

Tabela 7.3: Tabela contendo os resultados da comparação entre as médias dos dois sistemas.

O programa Compara.c, após obter os resultados de ambos os sistemas, calcula a variância amostral da diferença entre as médias e a semi-amplitude do intervalo de confiança. A figura 7.9 apresenta o relatório emitido pelo programa.

Como este programa utiliza os resultados da simulação de dois modelos sua execução é independente da geração do modelo e assim, ele pode ser inserido em qualquer parte de um ambiente de simulação, desde que tenha os dados resultantes da análise em disponibilidade. 


\section{ANALISE DAS SAIDAS DA SIMULACAO}

MODELO 1: M/M/1 Queue

MODELO 2: $M / M / 1$ Queue

VARIAVEL: $\mathrm{U}$ (server)

Intervalo de Confianca: $0.44765+/-0.06343$

Nivel de Confianca ( 8$): 95.0$

Variancia Amostral: 0.00261

Figura 7.9: Relatório para comparação entre as médias dos dois modelos.

\subsection{Estratégias para inclusão no ASiA}

Uma vez implementados e testados os módulos para um modelo de simulação smpl genérico, o próximo passo é definir o que deve ser modificado no ASiA para que possa interagir com os programas de análise.

O produto final do ASiA é o programa de simulação refletindo o modelo do usuário. Analogamente aos exemplo apresentados, este modelo deverá fazer a chamada ao método de análise desejado, alterar parâmetros de análise, transferir os valores observados da variável de interesse para o método e chamar o relatório que deverá mostrar o intervalo de confiança estimado e outros resultados. Assim, quando o ASiA estiver gerando o programa de simulação, todas estas informações já deverão estar definidas para que o produto final contenha todas as chamadas necessárias às funções, de forma que ao ser executado, ele próprio chame o método de análise escolhido pelo usuário de maneira adequada.

A integração do módulo de análise de saídas ao ASiA requer a alteração de dois outros módulos do ASiA: o Editor Gráfico e o Gerador de Aplicaçōes. Estas alterações são descritas nas próximas seções.

\subsubsection{Alterações no Editor Gráfico}

A maneira pela qual o usuário interage com o ASiA, conforme já abordado, é através da especificação do modelo no Editor Gráfico.

O Editor Gráfico tem duas funções básicas: fornecer ao usuário uma interface gráfica (para introduzir o seu modelo e a parametrização a ser considerada) e a geração de arquivos com dados para serem utilizados pelo gerador de aplicações.

Serão detalhadas a seguir as alterações a serem efetuadas em cada uma destas funções.

Com relação a interface gráfica, devem ser introduzidas ferramentas (caixas de diálogo, menus, etc.) que permitam ao usuário fomecer as informaçōes necessárias para a utilização do módulo de análise dos resultados, tais como:

- qual método de análise utilizar;

- quais parâmetros devem ser alterados;

- qual a variável de interesse;

- qual a facility obsenvada. 
Estas informações devem ser obtidas através do Editor Gráfico durante a especificação do modelo e armazenadas num arquivo para posterior geração do programa de simulaçāo e armazenamento dos resultados (a geração do arquivo será discutida no final desta seçāo).

Diversas mudanças no Editor Gráfico tornam-se necessárias. A primeira delas deve ocorrer na caixa de diálogo intitulada "Modelo" e consiste em excluir a leitura e apresentação dos seguintes campos:

- Tempo de warm up;

- Número máximo de entidades;

- Tamanho Batch;

- Valores Desprezados.

A razão disto é que estes valores deverão ser informados conforme o método de análise escolhido.

O próximo passo é definir qual método de análise deverá ser utilizado. Para isso, deve aparecer uma caixa de diálogo denominada "Método de Análise", conforme apresentada na figura 7.10. A resposta informada nesta caixa de diálogo fica armazenada na variável inteira Tipo_Metodo da estrutura análise. Seus valores possíveis são:

- 0 - para Nenhum,

- 1 - para Replicações ou

- 2 - para Batch Means.

Caso a opçāo "Nenhum" tenha sido escolhida, o Editor conclui a especificação do modelo de maneira normal, ou seja, gerando o modelo sem um método de análise e permitindo a execução de uma única rodada de simulação.

Caso algum método tenha sido escolhido, uma nova caixa deverá aparecer. Trata-se da caixa intitulada "Parâmetros de Análise", a qual, conforme o metodo escolhido, deverá apresentar os valores padrão e permitir sua alteração. O próprio Editor se encarrega de informar os valores padrão assumidos pelas variáveis em cada método.

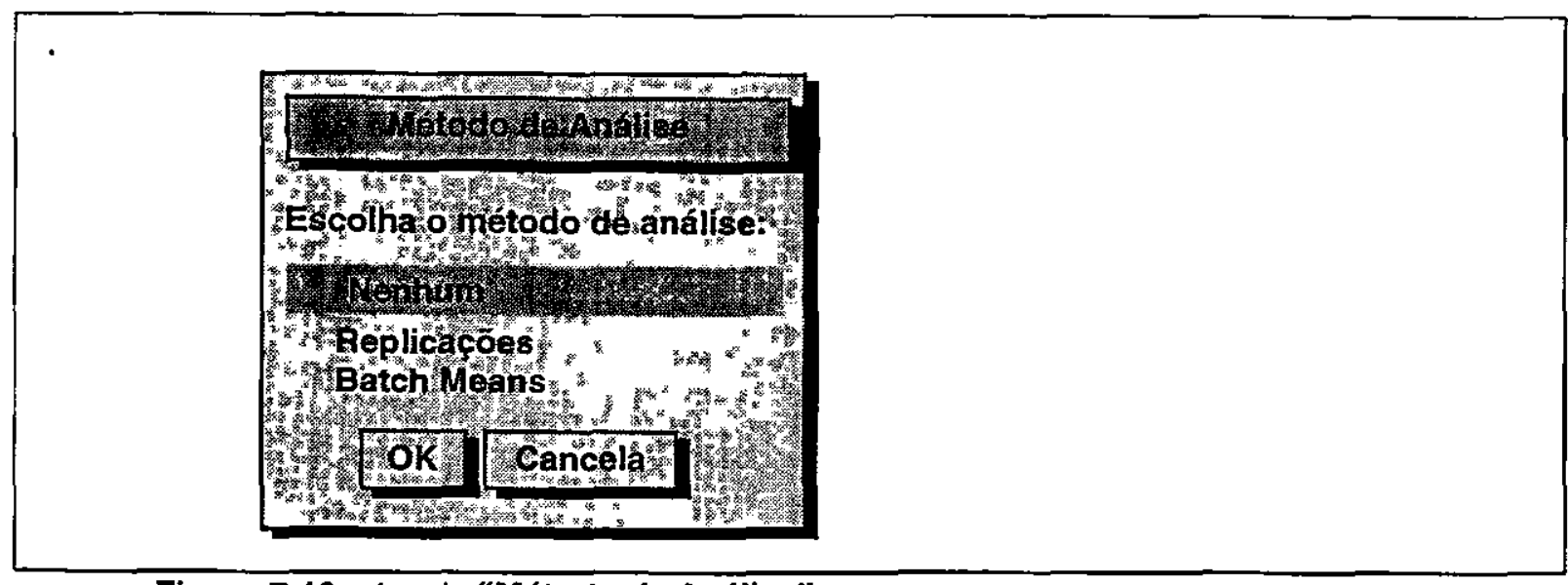

Figura 7.10:. Janela "Método de Análise" 
Caso o método seja o das Replicaçōes, a caixa de diálogo apresentada será a mostrada na figura 7.11 , com os valores pré-estabelecidos pelo programa correspondente.

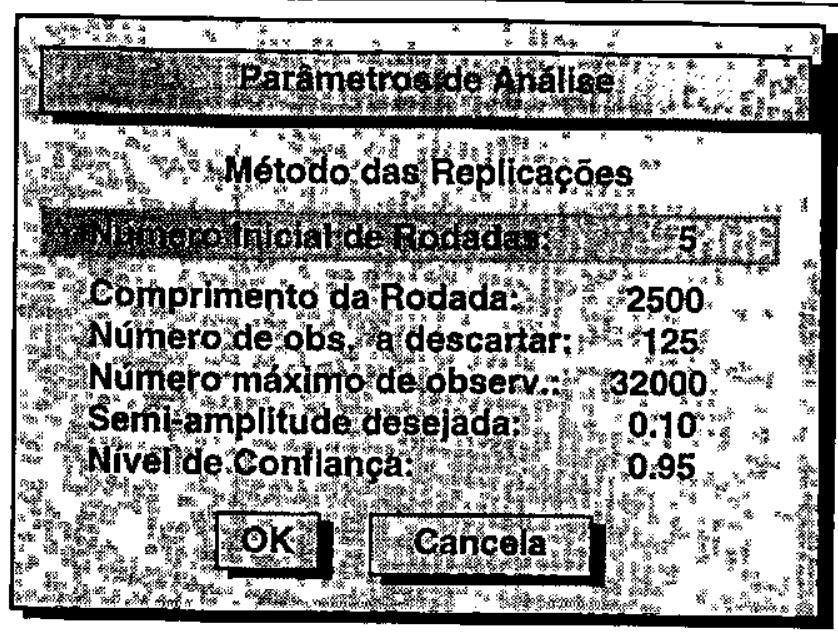

Flgura 7.11.: Janela "Parâmetros de Análise" para o Método das Replicações

Os valores lidos nesta caixa de diálogo ficarão armazenados na estrutura análise denominados conforme a tabela 7.4.

Caso o método Batch Means seja o escolhido, a caixa de diálogo será como apresentada na figura 7.12.

A tabela 7.4 apresenta a denominaçāo dos campos da estrutura análise que deverão armazenar os parâmetros do método das replicações e do método Batch Means.

O passo a seguir na especificação do modelo é definir a variável de interesse para a análise. Tanto esta etapa quanto a que virá a seguir são independentes do método escolhido.

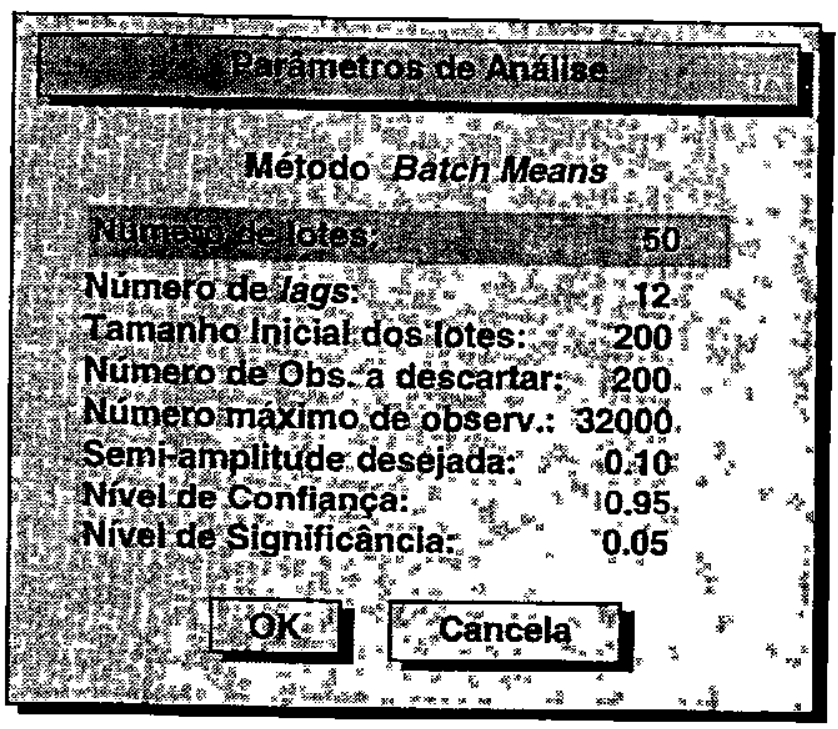

Figura 7.12.: Janela "Parâmetros de Análise" para o Método Batch Means. 


\begin{tabular}{|c|c|c|}
\hline $\begin{array}{c}\text { Nome do } \\
\text { Campo }\end{array}$ & $\begin{array}{c}\text { Significado no Método das } \\
\text { Replicaçōes }\end{array}$ & $\begin{array}{c}\text { Significado no Método Batch } \\
\text { Means }\end{array}$ \\
\hline i1 & Número inicial de rodadas & Número de lotes \\
\hline 12 & não utilizado & Número de lags \\
\hline 11 & Comprimento da rodada & Tamanho Inicial do lote \\
\hline 12 & Número de Obs. a descartar & Número de Obs. a descartar \\
\hline 13 & Número máximo de obs. & Número máximo de obs. \\
\hline r1 & Semi-amplitude & Semi-amplitude \\
\hline r2 & Nível de confiança & Nível de confiança \\
\hline r3 & não utilizado & Nível de significância \\
\hline
\end{tabular}

Tabela 7.4.: Correspondência entre os campos de análise e os parâmetros dos métodos.

Como já foi mencionado anteriormente, definir uma variável de interesse é muito fácil dentro do modelo de simulação. Basta saber exatamente o que se quer e o quê fazer para obtê-la. Isto consiste em definir uma fórmula para esta variável e inseri-la em um local apropriado dentro do modelo. Mas isso requer conhecimento de estatística e smpl.

Assim, a solução para o problema da definição da variável de interesse seria o próprio ASiA gerar tantas variáveis quanto possivel conforme o modelo e apresentá-las ao usuário para que ele efetuasse a escolha. Mas a implementação de tal solução iria, com certeza, requerer uma gama maior de conhecimentos estatísticos. Por isso, optou-se pela utilização das variáveis pré-definidas do smpl, a saber:

$\mathrm{U}(\mathrm{f})$ : Utilização Média da facility f;

$\mathrm{B}(\mathrm{f})$ : $\quad$ Período Médio de Ocupação da facility f;

$\mathrm{Lq}(\mathrm{f})$ : Comprimento Médio da fila da facility $\mathrm{f}$.

Para permitir a escolha da variável de interesse, uma nova caixa de diálogo é apresentada em seguida. Esta, é mostrada na figura 7.13 e intitula-se "Varlável para Anállse".

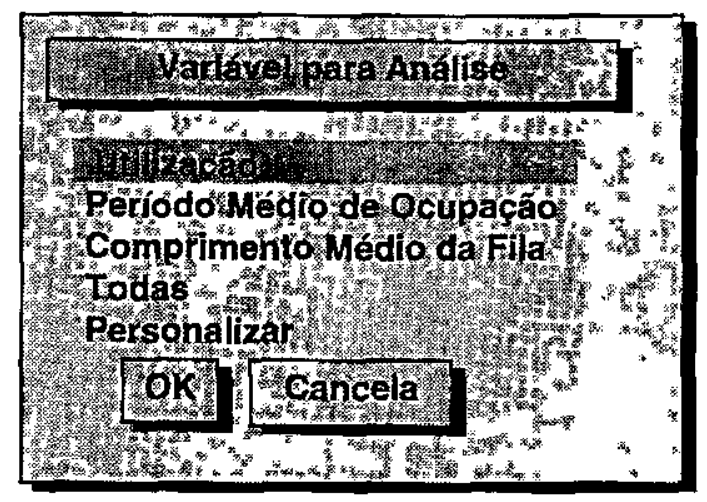

Flgura 7.13.: Janela "Variável para Anállse".

A opção "Personalizar" foi inserida nesta caixa de diálogo com o intuito de permitir que, futuramente, usuários experientes possam definir suas próprias variáveis, fornecendo uma fórmula para seu cálculo. Estes usuários, porém, 
deverão estar familiarizados com as variáveis do sistema, tanto do smpl como as utilizadas pelo programa de simulação, uma vez que não é possível para um ambiente de simulação prever todas as necessidades dos usuários.

A opção "Todas" refere-se à análise simultânea de todas as três variáveis referenciadas, não importando o método escolhido. Caso esta opção seja escolhida, aparecerá uma caixa de diálogo denominada "Parâmetros Complementares" referentes à obtenção do nível de confiança especificado para cada variável de interesse. Esta caixa de diálogo pode ser observada na figura 7.14 .

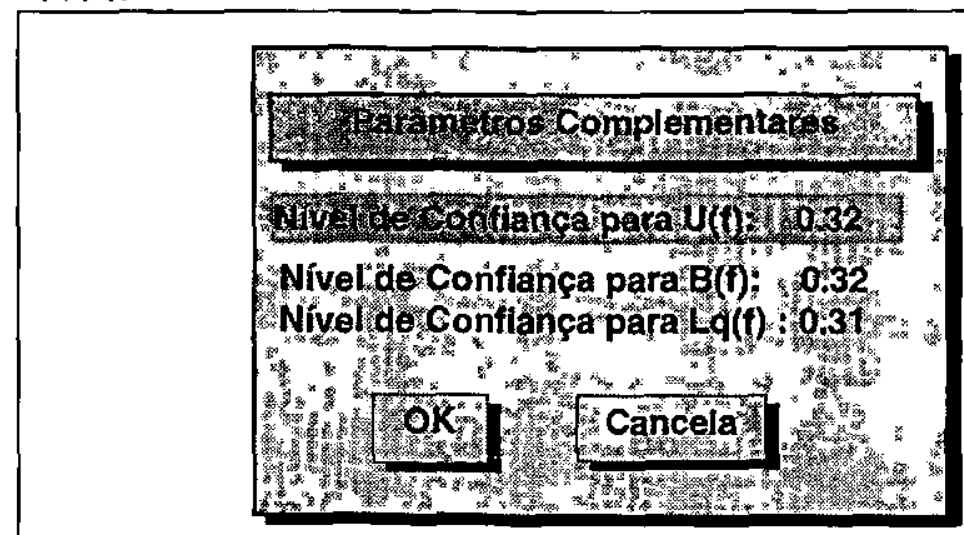

Figura 7.14.: Janela "Parâmetros Complementares" para Múltiplas Variáveis.

Uma vez obtida a resposta desta caixa de diálogo, será armazenado na estrutura análise em um campo do tipo char denominado Tipo_Var_Analise um dos seguintes valores: "U", "B", "Lq" ou "T".

Finalmente, se a opção escolhida na caixa de diálogo "Variável para Análise" nāo foi "Todas" , aparecerá então uma nova caixa intitulada "Facility para Análise", a qual solicitará que o usuário escolha uma facility, após apresentar todas as disponíveis, conforme o exemplo da figura 7.15.

A resposta do usuário para esta caixa de diálogo será armazenada na estrutura análise em um campo do tipo char denominado Nome_Fac_Analise.

É importante destacar que adaptar o Editor Gráfico aos métodos de análise de saídas não consiste simplesmente em criar caixas de diálogo apropriadas e inicializar a estrutura análise. Existem inúmeras rotinas integrantes do Editor que devem ser alteradas, como por exemplo, LerArqModelo, VerificaConsistencia Modelo, InicializaDadosModelo, entre outras.

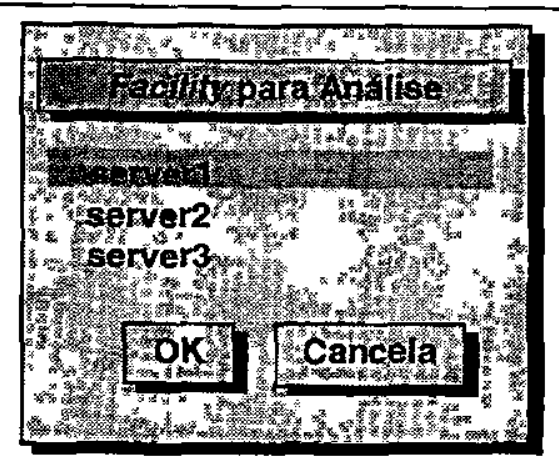

Figura 7.15.: Janela "Facility para Análise". 
Antes de encerrar a especificação do método de análise para o modelo, o Editor apresenta mais uma caixa de diálogo perguntando ao usuário se o modelo deverá ser utilizado em comparação com outro. Se a resposta do usuário for positiva, será gravado no campo NAC da estrutura análise o valor 1 , informando ao gerador que o modelo deverá fixar uma determinada seqüência de números aleatórios (nesta implementação, será definida a seqüência 1), da mesma forma que 0 outro modelo. Caso a resposta seja negativa, 0 valor 0 será gravado. $A$ caixa de diálogo responsável por esta solicitação será intitulada "Redução de Variância" pelo fato de a comparação entre sistemas utilizar a técnica de Números Aleatórios Comuns e é apresentada na figura 7.16.

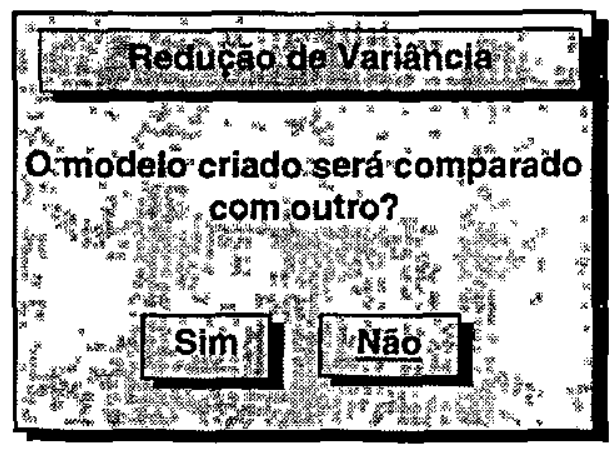

Figura 7.16.: Janela "Redução de Variância" (usada na comparação de sistemas).

O próximo passo é a geração do modelo da mesma forma que qualquer outro modelo que não tivesse solicitado análise de resultados.

As últimas alterações no Editor Gráfico surgem em decorrência da comparação entre dois sistemas. Este processo, por um lado, independe da geração do modelo, uma vez que utiliza modelos já prontos e executados, podendo dessa forma ser inseridos em qualquer outro ponto do ambiente de simulação, mas por outro requer que as duas condições anteriores sejam satisfeitas, ou seja, se o modelo já está pronto e executado. Neste trabalho, optou-se por inserir este método no sub-menu "Outros" do menu principal do ASiA, conforme pode ser visto na figura 7.17.

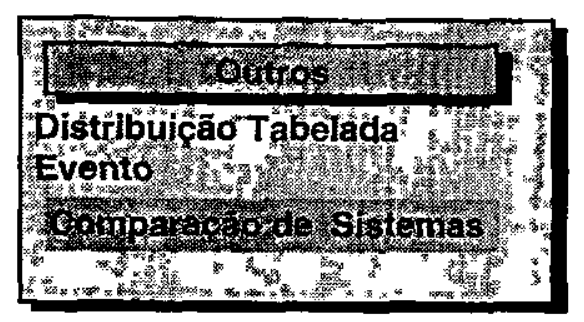

Figura 7.17.: Sub-Menu "Outros".

A verificação destas condições pode ser feita através da existência dos modelos (saber se eles estão prontos) e da verificação da variável exec da estrutura análise (saber se ele já foi executado). Além disso, o programa que 
implementa a comparação deve verificar também a variável $N A C=1$ na mesma estrutura, conforme explicado na seção 7.3.4.2.

Uma vez selecionada a opção "Comparação de Sistemas" neste sub-menu, um novo menu é apresentado contendo todos os possíveis modelos gravados. Uma vez escolhido o primeiro, este é assinalado com " 1 " e uma nova opção é aguardada. Assim que escolhido o segundo modelo, ele é assinalado com "2" e o processo de seleção é concluído. Em seguida, o programa responsável pela comparação de sistemas deve apresentar um relatório, caso não seja detectada nenhuma irregularidade.

Conforme discutido no início desta seção, uma segunda função do Editor Gráfico é a geração de arquivos com informações que serão utilizadas pelo gerador de aplicaçōes. Isto e', uma vez definidas todas as características do modelo, estas informações ficam armazenadas em arquivos com extensão ".mod" e ".rec" conforme apresentados a seguir:

- arquivos .mod: especificam o modelo a ser considerado através das seguintes variáveis:

\begin{tabular}{|l|l|}
\hline \multicolumn{1}{|c|}{ Nome } & \multicolumn{1}{c|}{ Função } \\
\hline nome_modelo & Corresponde ao nome do modelo a ser gerado; \\
\hline Parametro_01 & $\begin{array}{l}\text { Indica se o usuário deseja ou não ativar o módulo mtr, uma interface } \\
\text { interativa do SMPL para a execução do modelo de simulação; }\end{array}$ \\
\hline Tempo & Limita o periodo de simulação por tempo de execução; \\
\hline Num_voltas & $\begin{array}{l}\text { Limita a simulação por número de ciclos que os clientes devem } \\
\text { executar no sistema; }\end{array}$ \\
\hline Trace & Ativa/Desativa o trace (ferramenta de depuração do SMPL); \\
\hline Relatorio_final & $\begin{array}{l}\text { Indica se o usuário deseja ou não que o relatório padrão do SMPL seja } \\
\text { gerado; }\end{array}$ \\
\hline Nome_argsaida & Nome do arquivo que contém o programa de simulação a ser gerado; \\
\hline Tempo_prim_chegada & Instante em que irá ocorrer a chegada do primeiro cliente ao sistema; \\
\hline Distrib_tab & Indica o número de novas distribuições definidas pelo usuário; \\
\hline Reesc & Define se existem recursos sem fila no modelo. \\
\hline
\end{tabular}

A seguinte estrutura de dados armazena os valores descritos:

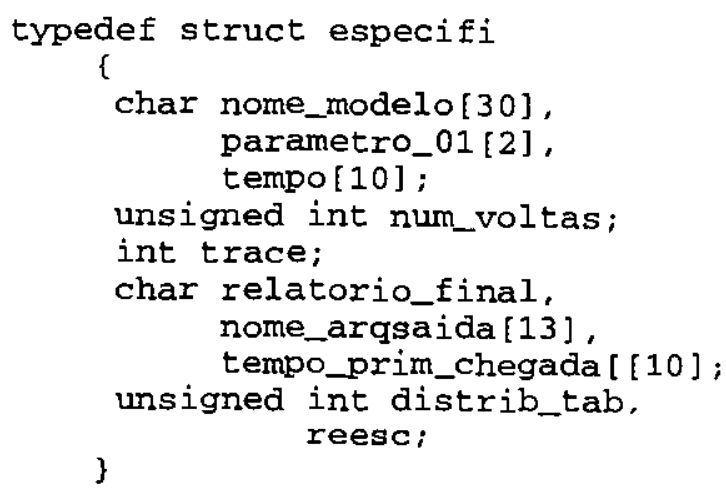

- arquivos .rec: especificam os recursos do modelo através das seguintes variáveis: 


\begin{tabular}{|c|c|}
\hline Nome & Funçāo \\
\hline Ident_rec & Identificação do recurso; \\
\hline Nome_recurso & Identificação do recurso para emissāo de relatórios e mensagens; \\
\hline Num_servidores & Número de servidores do recurso; \\
\hline Distribuicao_servico & Distribuição do tempo de serviço; \\
\hline Est_max_min & $\begin{array}{l}\text { Indica se o usuário deseja incluir no programa, estatisticas sobre o } \\
\text { tamanho máximo e mínimo da fila; }\end{array}$ \\
\hline Est_fila_vazia & $\begin{array}{l}\text { Indica se o usuário deseja incluir estatísticas sobre a porcentagem } \\
\text { de vezes que o cliente encontra a fila vazia; }\end{array}$ \\
\hline Media_servico & Tempo médio de serviço; \\
\hline Desvio_padrao_servico & Desvio padrão do tempo de serviço; \\
\hline Pto_triang_servico & $\begin{array}{l}\text { Ponto mais provável da distribuição triangular para o tempo de } \\
\text { serviço; }\end{array}$ \\
\hline Seq_num_aleat_servico & Seqüência de Números aleatórios para tempo de serviç; \\
\hline Disciplina & $\begin{array}{l}\text { Indica o algoritmo de escalonamento para a formação de filas e } \\
\text { atendimento aos clientes; }\end{array}$ \\
\hline Escolha_fila & $\begin{array}{l}\text { Algoritmo para determinar de qual fila se deve retirar o próximo } \\
\text { cliente a ser atendido; }\end{array}$ \\
\hline Escolha_cliente & Algoritmo para determinar em qual fila o cliente deverá entrar; \\
\hline Escolha_servidor & $\begin{array}{l}\text { Indica a maneira de escolher um servidor quando mais de um } \\
\text { estiver disponivel; }\end{array}$ \\
\hline Escolha_prox_rec & Determina o modo de decisāo para a escolha do próximo recurso; \\
\hline Distribuicao_chegada & Distribuição do tempo entre chegadas dos clientes; \\
\hline Media_chegada & Tempo médio entre as chegadas de novos clientes ao sistema; \\
\hline Desvio_padrao chegada & Desvio padrão do tempo entre as chegadas dos clientes; \\
\hline Pto triang chegada & Ponto mais provável da distribuição triangualr para as chegadas; \\
\hline Seq_num_aleat_chegada & $\begin{array}{l}\text { Seqüência para a geração de números aleatórios para o tempo } \\
\text { entre chegadas; }\end{array}$ \\
\hline Entradas_saidas & $\begin{array}{l}\text { Determinação do número do próximo recurso a ser utilizado pelo } \\
\text { cliente; }\end{array}$ \\
\hline Sem_fila & Indica se o recurso possui ou não fila; \\
\hline Num_filas & Indica o número de filas do recurso; \\
\hline Flag_sinc & Indica com quantos recursos um recurso passivo está sincronizado; \\
\hline Libera_recursos & $\begin{array}{l}\text { Indica se deve liberar um recurso passivo após a sincronização } \\
\text { com outros recursos. }\end{array}$ \\
\hline
\end{tabular}

Estes valores são armazenados na seguinte estrutura:

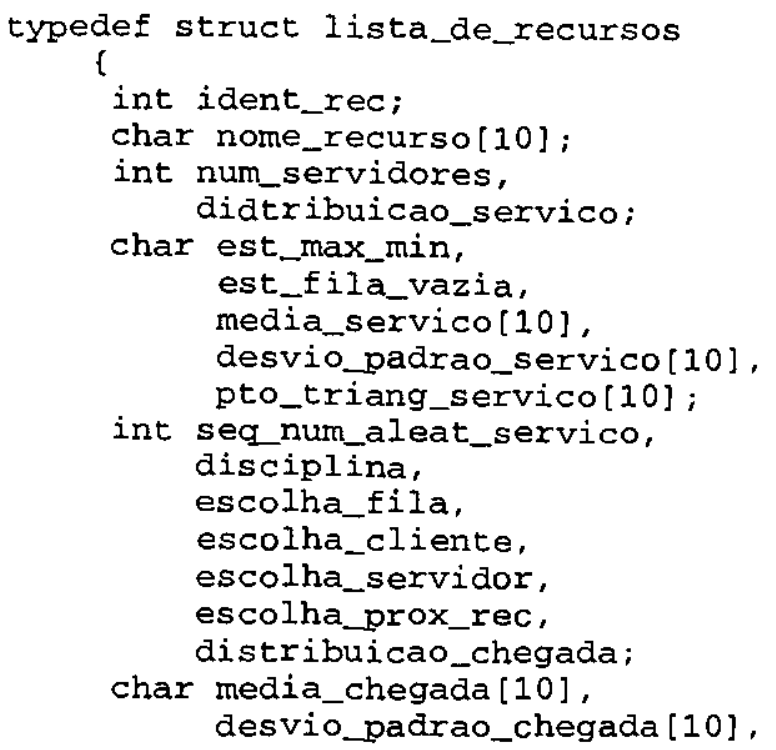




$$
\text { pto_triang_chegada [10]; }
$$

int seq_num_aleat_chegada;

char entradas_saidas [41], sem_fila;

unsigned int num_filas,

$$
\text { flag_sinc; }
$$

char libera_recurso:

] lista_recursos:

Para a inclusão do módulo de análise dos resultados, um novo arquivo com extensão ".anl" deve ser criado. Este arquivo deverá ser inicializado na especificação do modelo e alimentado sempre que o modelo for executado e deverá conter todos os aspectos referentes à execução do método de análise escolhido pelo usuário.

\begin{tabular}{|c|c|}
\hline Nome & Função \\
\hline Tipo Metodo & Indica o método selecionado; \\
\hline Exec & Indica se o modelo já foi executado ou não; \\
\hline NAC & Indica se uma determinada seqüência de números aleatórios será fixada; \\
\hline$i 1$ & Número inicial de rodadas ou de lotes; \\
\hline 12 & Número de lags para o cálculo dos coeficientes de autocorrelação; \\
\hline 11 & Comprimento das rodadas ou tamanho inicial dos lotes; \\
\hline 12 & Número de observações iniciais a descartar; \\
\hline 13 & Número máximo de observaçōes a colecionar; \\
\hline$r 1$ & Semi-amplitude especificada; \\
\hline$r 2$ & Nivel de confianca especificado; \\
\hline$r 3$ & $\begin{array}{l}\text { Nivel de significância especificado para o cálculo dos coeficientes de } \\
\text { autocorrelação; }\end{array}$ \\
\hline ru2 & Nivel de confiança especificado para U(); \\
\hline b2 & Nivel de confiança especificado para B(); \\
\hline rlq2 & Nivel de confiança especificado para Lq(); \\
\hline tipo_var_analise & Indica o tipo da variável a ser analisada; \\
\hline nome_fac analise & Nome da facility escolhida para análise; \\
\hline Media_grande & Média estimada para a variável de interesse; \\
\hline$m g U$ & Média estimada para $\mathrm{U}()$ \\
\hline$m g B$ & Média estimada para $\mathrm{B}()$ \\
\hline$m g L q$ & Média estimada para $\mathrm{Lq}()$ \\
\hline Semi_ampl & Semi-Amplitude estimada para a variável de interesse; \\
\hline saU & Semiramplitude estimada para $\mathrm{U}()$ \\
\hline$s a B$ & Semi-amplitude estimada para $\mathrm{B}()$ \\
\hline salq & Semi-amplitude estimada para $\mathrm{Lq}()$ \\
\hline med & Média dos lotes ou rodadas obtidos durante a simulação; \\
\hline$m U$ & Média dos lotes ou rodadas para U() \\
\hline$m B$ & Média dos lotes ou rodadas para $\mathrm{B}()$ \\
\hline$m L q$ & Média dos lotes ou rodadas para Lq() \\
\hline Num_rod_lot & Número de lotes ou rodadas colecionados durante a simulação \\
\hline
\end{tabular}

As seguintes variáveis são armazenadas neste arquivo:

A estrutura de dados apresentada a seguir armazena os valores discutidos:

type struct resultados

i

int Tipo_Método, exec, NAC,

i1, i2;

long 11, 12, 13, 


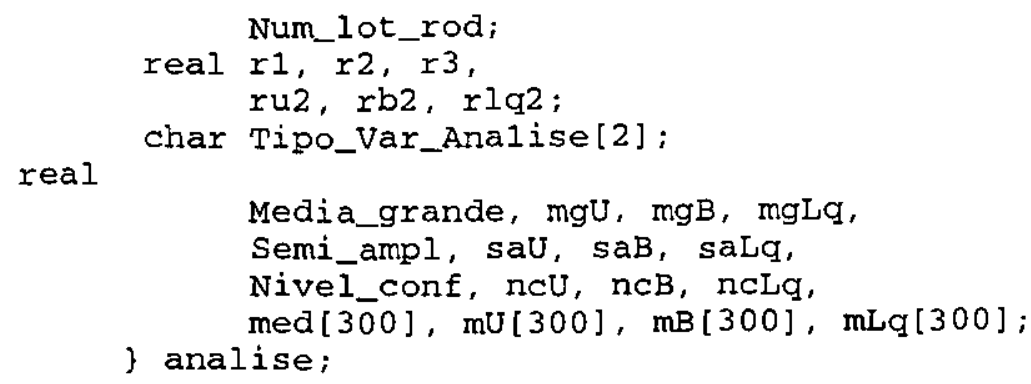

Esta estrutura é inicializada quando o modelo é criado (exec=0). Quando o modelo é executado, os resultados da simulação são armazenados nos campos de analise e exec=1. Quando o modelo é gerado deve haver um comando para armazenar os valores calculados em analise, o que será descrito posteriormente nesta seção.

Assim, os arquivos com extensão ".mod", ".rec" e ".anl", são utilizados pelo módulo Gerador de aplicaçōes para a geração do produto final, sendo que o último deles será utilizado também pelo modelo para armazenar os resultados calculados durante sua execução.

\subsubsection{Alterações no Gerador de Aplicações}

O gerador efetua a geração do programa de simulação a partir de um gabarito, conforme exposto no capítulo 5. Para incorporar os métodos de análise de saída são necessárias algumas alterações no gabarito que aparecem destacadas na figura 7.18.

O gerador de aplicação lê cada linha do gabarito (através da rotina Le_Gabarito) e executa os comandos identificados pelo sinal \%.

A primeira alteração no gabarito foi a inclusão dos comandos $\% E, \% H, \% R$ e \%L. Quando a rotina Le_Gabarito encontra o comando \%E, decide que deve executar a primitiva Gera_Metodo_Analise_Saida, baseando-se na opção feita pelo usuário na caixa de diálogo "Método de Análise", apresentada na figura 7.10. A implementação atual da rotina Le_Gabarito é apresentada no Apêndice B desta dissertação de mestrado e na figura 7.19 pode ser observada a implementação da rotina Gera_Metodo_Analise_Saida. Esta rotina verifica qual método de análise de saídas foi selecionado (Tipo_Metodo), qual o tipo do variável que deve ser analisada (Tipo_Var_Analise) e grava no produto final o comando adequado à chamada do método especificado.

O próximo comando encontrado por Le_Gabarito é \%H e a diretiva executada é Define_Param_Analise. Esta rotina é responsável por inserir no produto final, o comando apropriado para a alteração dos parâmetros de análise. Para isso, verifica inicialmente qual o método escolhido (variável Tipo_Metodo) e qual a variável para análise, para a determinação do comando apropriado. Esta rotina pode ser ser vista na figura 7.20.

Ao gerar o loop de controle da rodada de simulação, o gerador deve verificar se algum método de análise de saídas está sendo utilizado (Tipo_Metodo diferente de zero). Isto é necessário para que a variável de controle utilizada no método de análise ( $r$ ) possa controlar a obtenção dos valores observados. A 
rotina responsável pela geração do loop é denominada Gera_Loop e foi alterada conforme pode ser visto na figura 7.21.

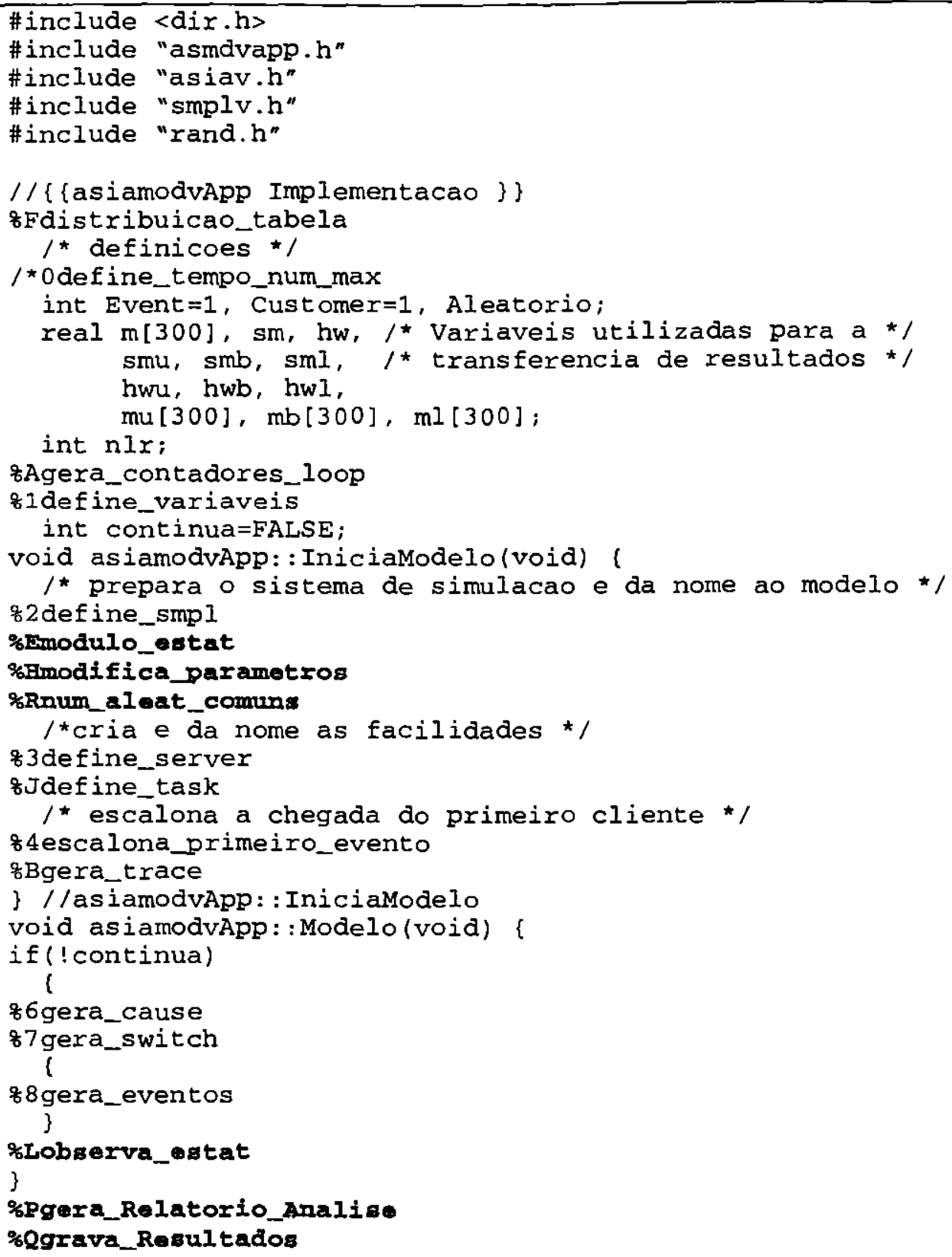

\} // asiamodvApp : : Modelo

BOOL asiamodvApp :: ParadaModelo (void) \{ return (FALSE);

\} // asiamodvApp : : ParadaModelo

int OwlMain (int, char* []) \{ asiamodvApp App;

return App.Run();

Figura 7.18.: Novo Gabarito utilizado. 


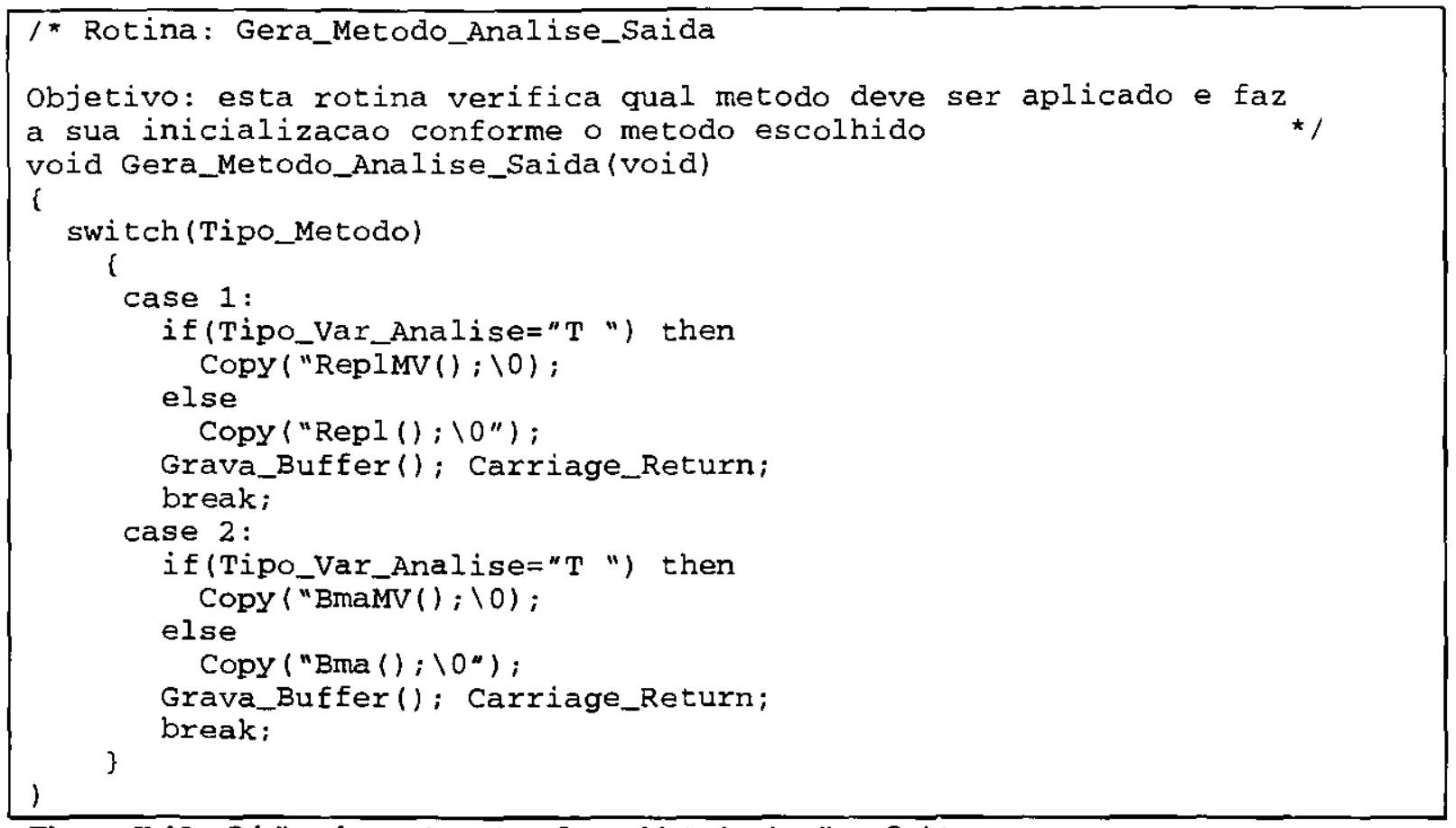

Figura 7.19.: Código-fonte da rotina Gera_Metodo_Analise_Saida..

O próximo comando encontrado por Le_Gabarito é \%R, provocando a execução da rotina Gera_Num_Aleat_Comuns, conforme pode ser observada na figura 7.22. Esta rotina tem por finalidade fixar uma seqüência de números aleatórios (seqüência 1) para ser utilizada na comparação entre dois sistemas (técnicas de redução de variância conforme discutido no capítulo 5) a partir da verificação do valor armazenado na variável NAC.

Após executar todos os comandos que aparecem em seguida a $\% \mathrm{H}$, a rotina Le_Gabarito encontra o comando \% e passa a executar Gera_Obs_Valores. Esta rotina também foi inserida no gerador e pode ser observada na figura 7.23. A partir da verificação de qual método está sendo utilizado (Tipo_Metodo) e da variável de interesse (Tipo_Var_Analise), esta rotina determina qual comando deverá ser inserido no produto final de modo a permitir a transferência dos valores do programa de simulação ao método de análise correspondente.

A próxima alteração inserida no gabarito foi a inclusão do comando $\% P$, 0 qual será utilizado para gerar o relatório de análise antes do relatório padrão do smpl. A rotina responsável por isso é Gera_Relat_Analise e é apresentada na figura 7.24. Esta rotina, de maneira análoga às anteriores, verifica as variáveis Tipo_Metodo e Tipo_Var_Analise para determinar qual comando deve ser irıserido no produto final, conforme o método de análise selecionado.

Finalmente, a última alteração inserida no gabarito foi a inclusão do comando $\% Q$, a qual, ao ser lida pela rotina $L$ e_Gabanito causa a execução da rotina Gera_Gravacao_Resultados. Esta rotina, insere no produto final o comando adequado para a gravação dos resultados da análise na estrutura análise conforme o método que está sendo empregado. 
/* Rotina: Define_Param_Analise

Objetivo: permite que o comando para alteracao dos parametros seja inserido no modelo de simulacao logo apos a inicializacao * void Define_Param_Analise(void) \{

if (Tipo_Var_Analise $==" \mathrm{~T}$ ") then \{

if (Tipo_Metodo! $=0)\{$

if (Tipo_Metodo==1)

else

Copy ("Define_Par_RMV(); $\backslash 0 "$ );

Copy ("Define_Par_BMV (); $\backslash 0 ")$;

strncat (Buffer,il, strlen(i1));

strcat (Buffer, ",");

if (Tipo_Metodo==2) \{

strncat (Buffer, i2, strlen(i2));

strcat (Buffer,","); \}

strncat (Buffer,11, strlen(11));

strcat (Buffer," ") ;

strncat (Buffer, 12, strlen (12));

strcat (Buffer,",");

strncat (Buffer, 13, strlen (13));

strcat (Buffer,", ");

strncat (Buffer,r1, strlen(r1));

strcat (Buffer,",");

strncat (Buffer, r2, strlen(r2));

strcat (Buffer," ",);

if (Tipo_Metodo $==2$ ) \{

strncat (Buffer,r3, strlen(r3));

strcat (Buffer," , "); \}

strncat (Buffer, ru2, strlen(ru2));

strcat (Buffer,",");

strncat (Buffer, rb2, strlen(rb2));

strcat (Buffer,",");

strncat (Buffer,rlg2, strlen(rlq2));

strcat (Buffer,");");

else \{

Grava_Buffer(); Carriage_Return; \}

if $($ Tipo_Metodo! $=0)\{$

if (Tipo_Metodo==1) \{

Copy ("Define_Par_Repl (); 10");

strncat(Buffer,i1, strlen(i1));

strcat (Buffer,","); \}

else \{

Copy("Define_Par_Bm(); $10 "$ ") ;

strncat (Buffer, i.1,strlen(i1));

strcat (Buffer,",");

strncat (Buffer, i2, strlen(i2));

strcat (Buffer,",");

strncat (Buffer, 11, strlen(11));

strcat (Buffer,",");

strncat (Buffer, 12, strlen(12));

strcat (Buffer,",");

strncat (Buffer,13, strlen(13));

strcat (Buffer,",");

strncat (Buffer, r1, strlen(r1));

strcat (Buffer, ", ");

strncat (Buffer,r2, strlen(r2));

if (Tipo_Metodo= $=2$ ) \{

strncat (Buffer, r3, strlen(r3));

strcat (Buffer,","); \}

strcat (Buffer,");");

Grava_Buffer(); Carriage_Return; \} \}

Figura 7.20.: Código-fonte da rotina Define_Param_Analise. 
A rotina $\operatorname{Grava}(p 1, p 2)$ no produto final simboliza a gravação do resultado p2 no campo $p 1$ de análise. A figura 7.25 apresenta o código da rotina Gera_Gravacao_Resultados, a qual determina o método de análise selecionado e a variável de interesse para a definição do comando que deverá ser inserido no produto final.

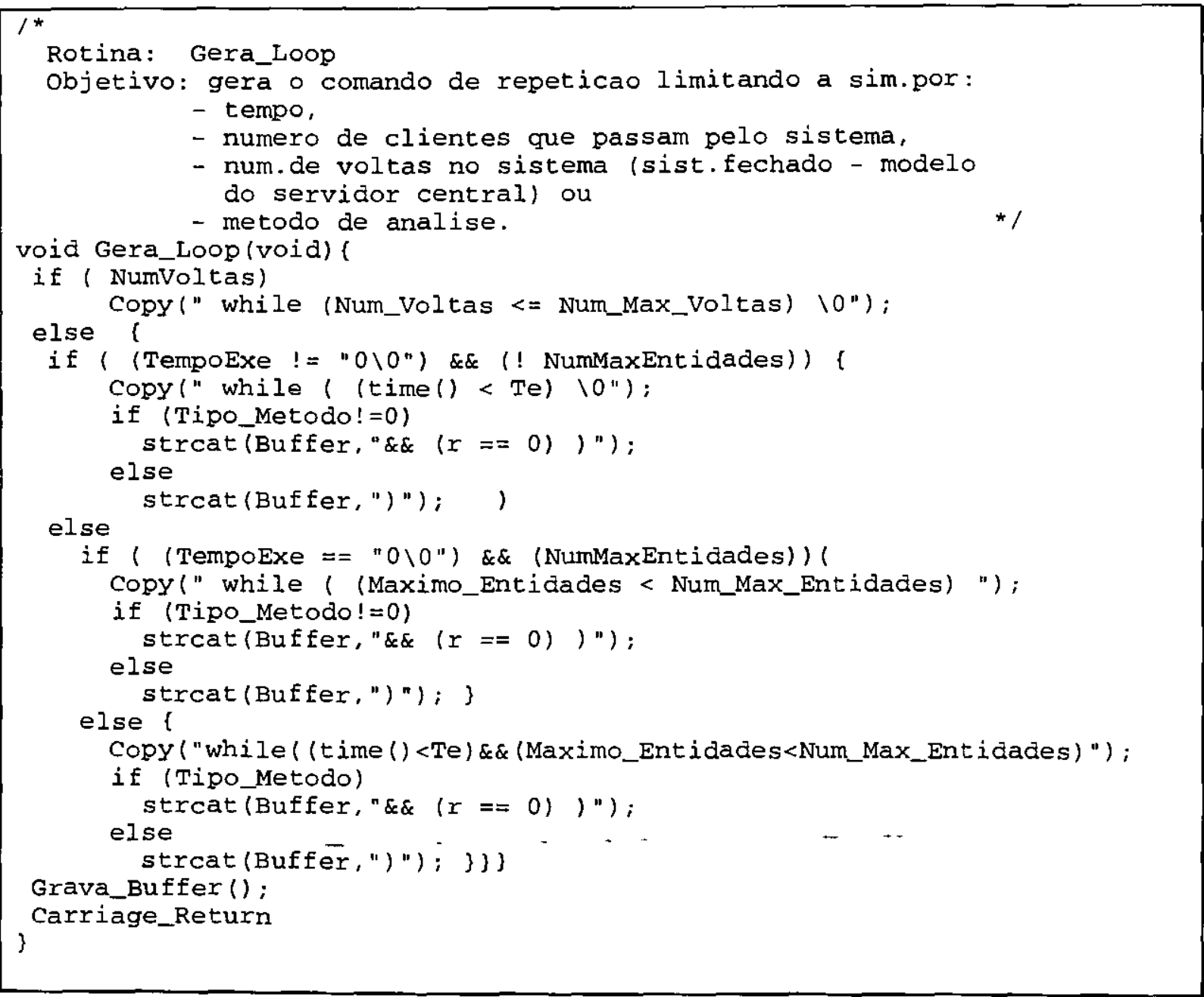

Figura 7.21.: Código-fonte da rotina Gera_Loop.

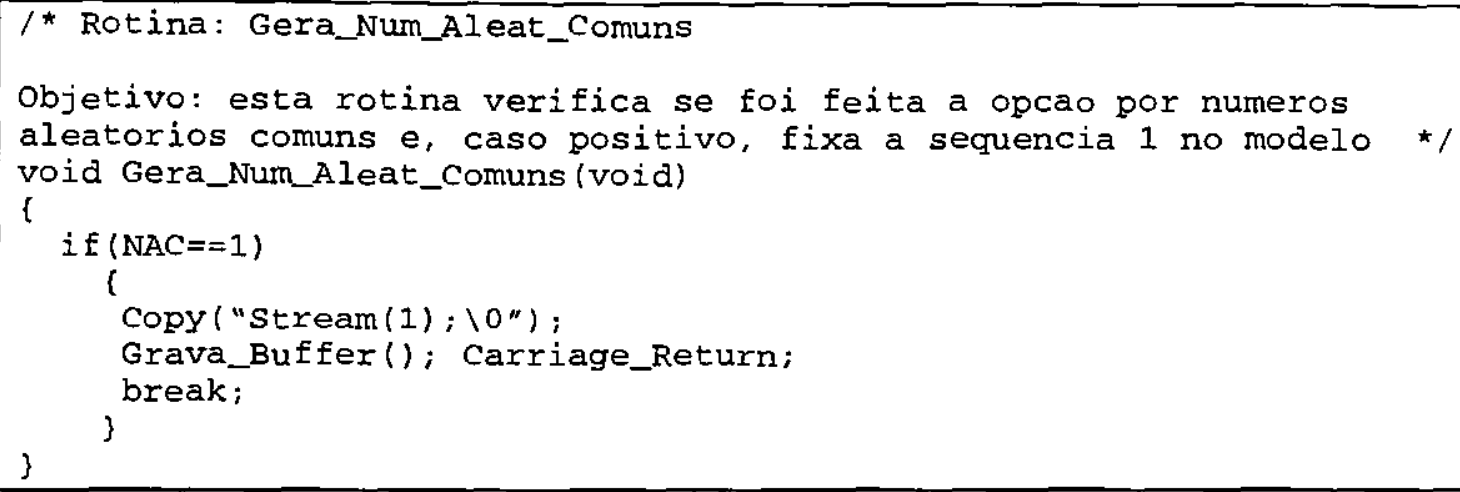

Figura 7.22.: Codigo-fonte da rotina Gera_Num_Aleat_Comuns. 


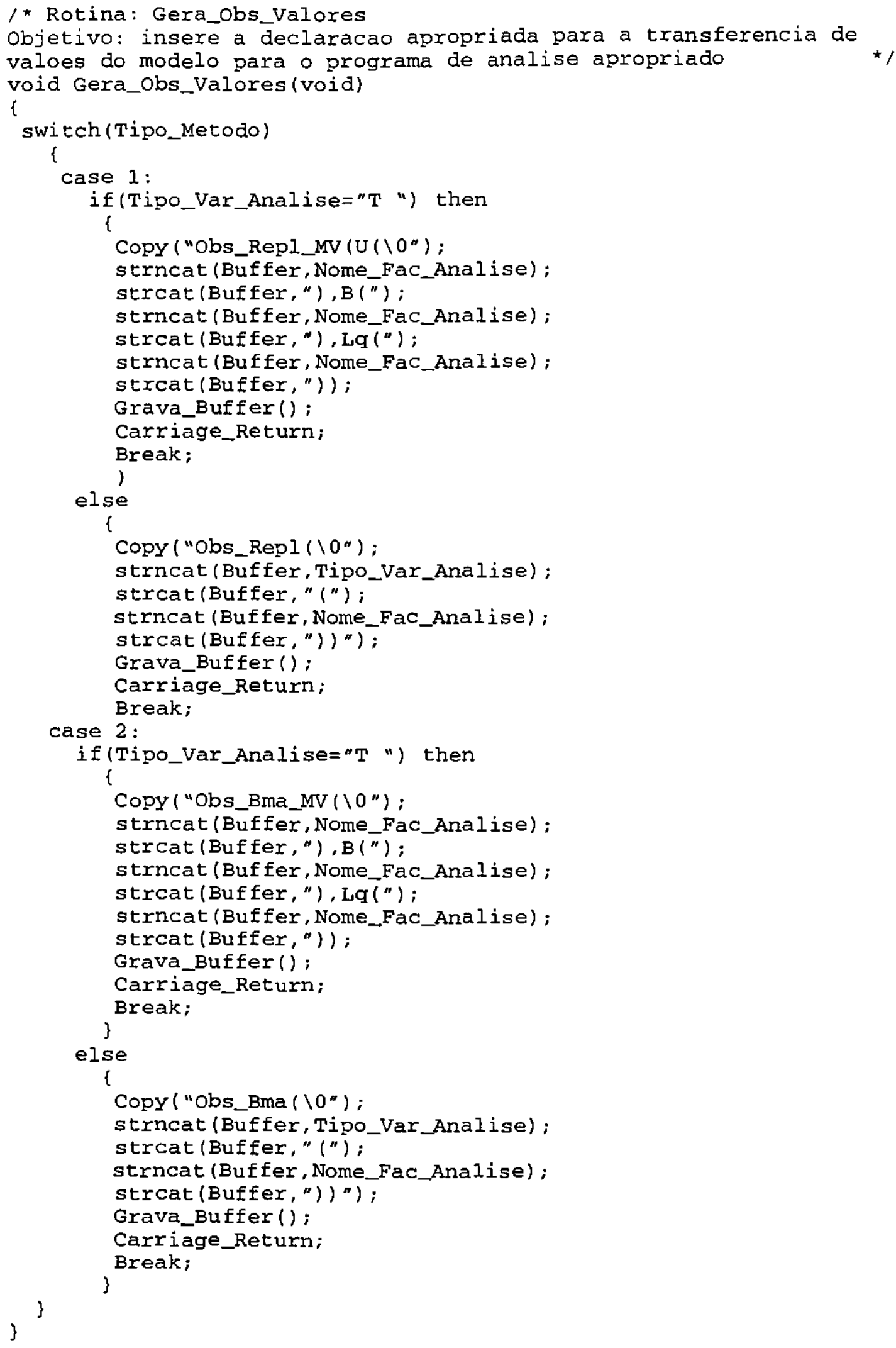

Figura 7.23.: Código-fonte da rotina Gera_Obs_Valores. 


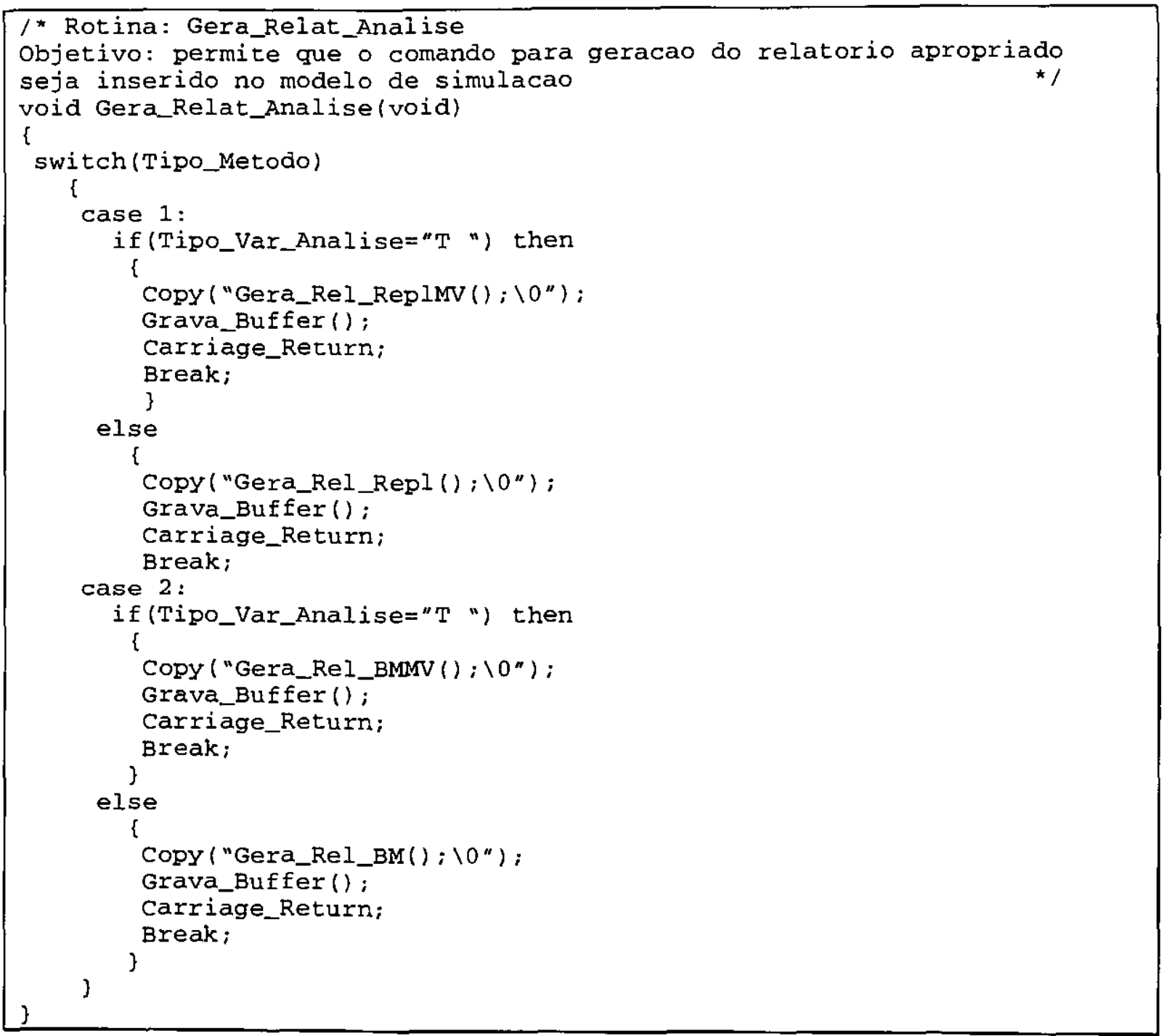

Figura 7.24.: Código-fonte da rotina Gera_Relat_Analise.

Exemplo: Programa gerado pelo ASiA com as chamadas às rotinas do módulo de Análise de Saídas.

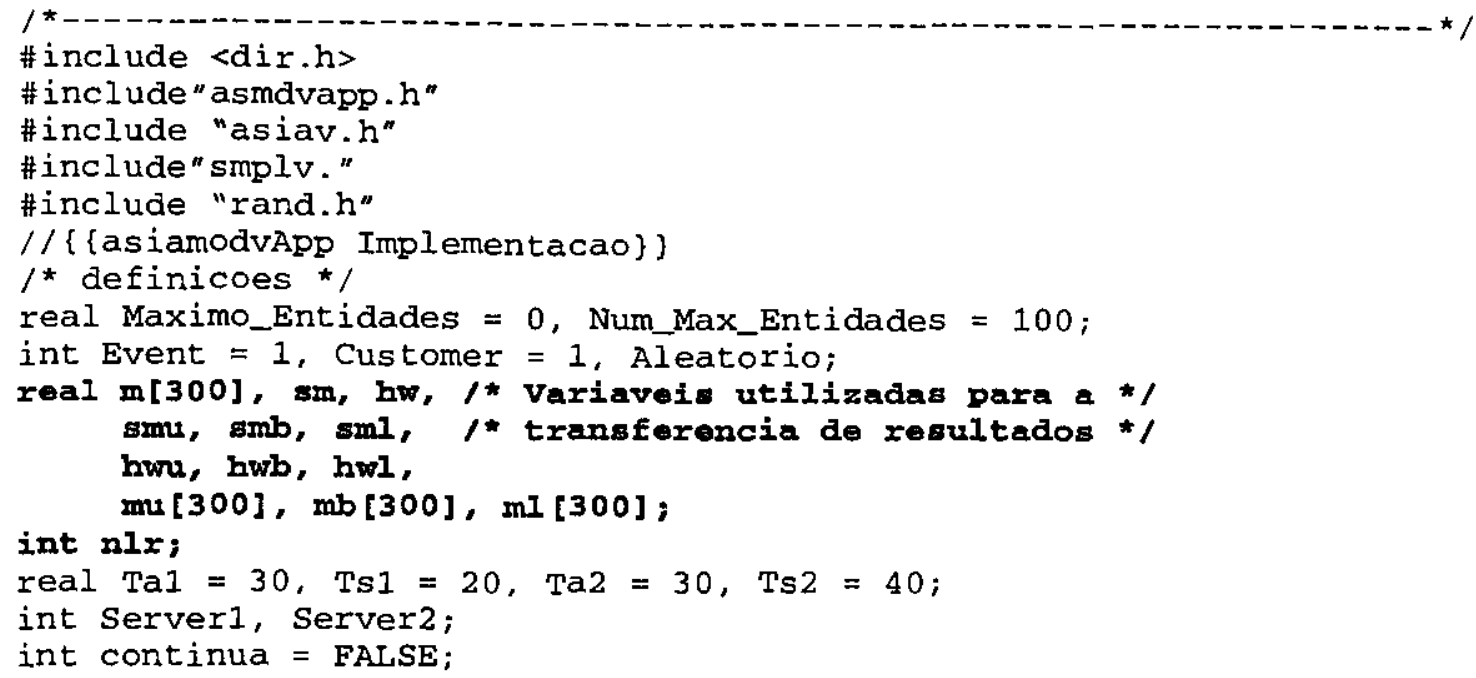




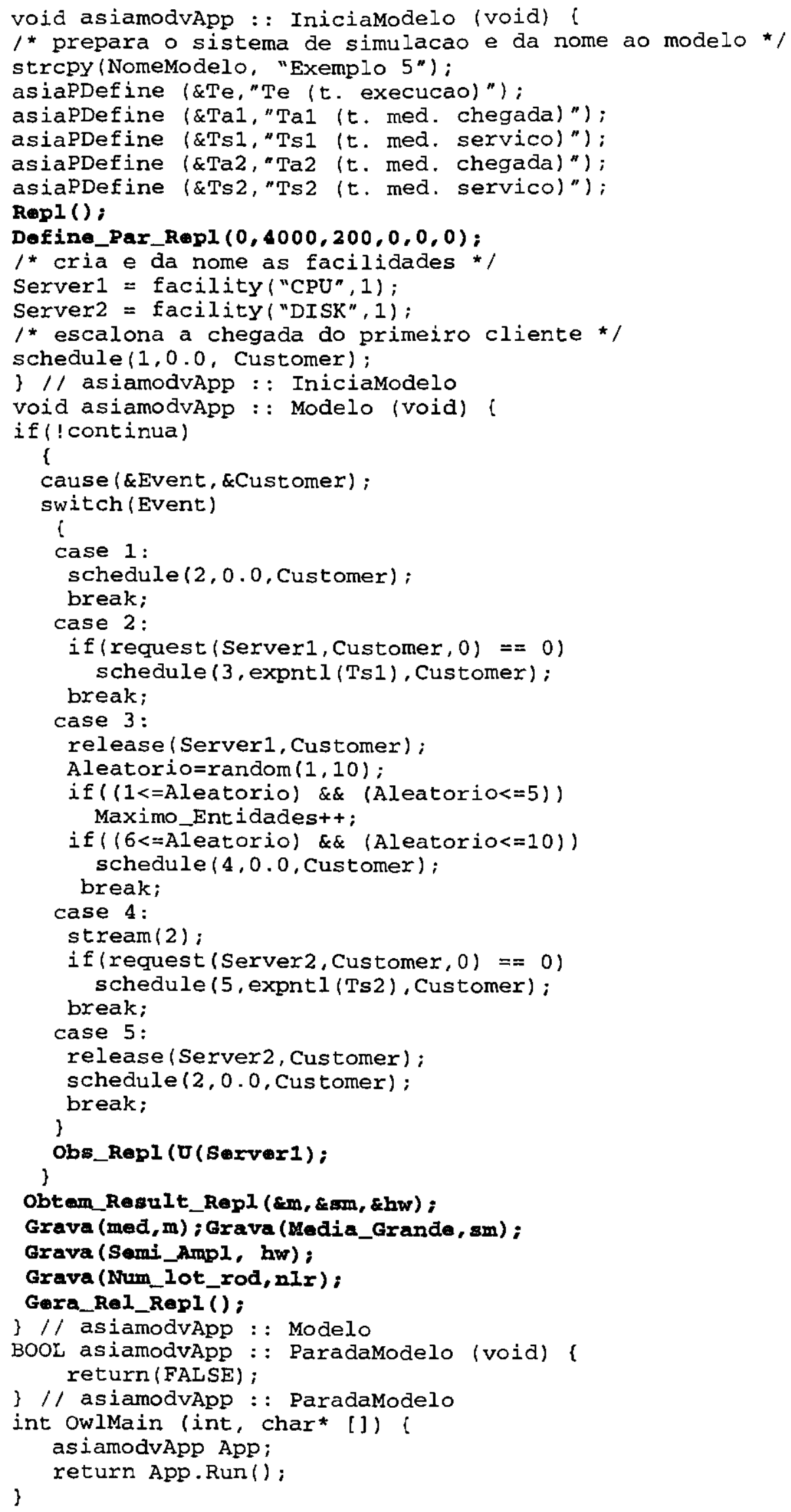


/* Rotina: Gera_Gravacao_Resultados

objetivo: permite que o comando para obtencao dos resultados da analise sejam obtidos do metodo de analise e que sejam gravados nos campos correspondentes da estrutura analise void Gera_Gravacao_Resultados (void) \{ switch (Tipo_Metodo) (

case 1:

if (Tipo_Var_Analise="T ") then (

Copy ("Obtem_Result_RMV (\&nIr,\&mu, \&smu, \&hwu,") ;

strcat (Buffer, "\&mb, \&smb, \&hwb,");

strcat (Buffer, "\&ml, \&sml, \&hwl); $\backslash 0 "$ );

Grava_Buffer(); Carriage_Return;

Copy ("Grava (mU， mu); Grava (mB,mb) ; Grava (mLq, ml\0");

Grava_Buffer(); Carriage_Return();

Copy ("Grava(mgU, smu); Grava(mgB, smb) ; Grava (mgLq, sml\0");

Grava_Buffer(); Carriage_Return();

Copy ("Grava (saU, hwu); Grava (saB,hwb); Grava (saLq, hwl \0");

Grava_Buffer(); Carriage_Return();

Copy ("Grava (Num_lot_rod, nlr); $\backslash 0^{\prime \prime}$ );

Grava_Buffer(); Carriage_Return();

else \{

Break; )

Copy ("Obtem_Result_Repl (\&nlr,\&m, \&sm, \&hw); :0");

Grava_Buffer(); Carriage_Return;

Copy ("Grava (med, m) ;Grava (Media_Grande, sm) ; $10 "$ ) ;

Grava_Buffer(); Carriage_Return;

Capy ("Grava (Semi_Ampl, hw) ; \0");

Grava_Buffer(); Carriage_Return();

Copy ("Grava (Num_lot_rod, nlr); $\backslash 0 "$ );

Grava_Buffer(); Carriage_Return();

case 2

Break; \}

if (Tipo_Var_Analise="T ") then \{

Copy ("Obtem_Result_BMV (\&nlr,\&mu, \&smu, \&hwu,") ;

strcat (Buffer, "\&mb, \&smb, \&hwb, ");

strcat (Buffer, "\&ml, \&sml, \&hwl); $\backslash 0 "$ );

Grava_Buffer(); Carriage_Return;

Copy ("Grava (mU, mu); Grava (mB,mb); Grava (mLq,ml\0");

Grava_Buffer(); Carriage_Return();

Copy ("Grava (mgu, smu) ; Grava (mgB, smb) ; Grava (mgLq, sml\0") ;

Grava_Buffer(); Carriage_Return();

Copy ("Grava (sau, hwu); Grava(saB,hwb); Grava(saLq, hwl\0");

Grava_Buffer(); Carriage_Return();

Copy ("Grava (Num_lot_rod, nlr) : $\backslash 0$ ");

Grava_Buffer(); Carriage_Return();

Break; )

else (

Copy ("Obtem_Result_BM(\&nlr,\&m,\&sm, \&hw); \0");

Grava_Buffer();

Carriage_Return;

Copy ("Grava (med,m) ; Grava (Media_Grande,sm) ; $\backslash 0 "$ ) ;

Grava_Buffer(); Carriage_Return;

Copy ("Grava (Semi_Ampl, hw) ; $\backslash 0 "$ );

Grava_Buffer(); Carriage_Return();

Copy ("Grava (Num_lot_rod, nlr); $\backslash 0$ ");

Grava_Buffer(); Carriage_Return() ;

)

Break;

Figura 7.25.: Código-fonte da rotina Gera_Gravacao_Resultados. 


\subsubsection{Comentários sobre a implementação da Técnica Heurística e do Método Bootstrap}

A implementação da técnica heurística apresentada no capítulo 6 requer muito menos trabalho que os outros métodos desenvolvidos. A técnica heurística requer que apenas três rodadas de simulação sejam executadas e que os resultados das variáveis de interesse sejam armazenados para o cálculo da convergência das médias. Uma vez atingida a convergência das médias, o intervalo de confiança é calculado de maneira idêntica aos métodos desenvolvidos.

Para isso, bastam algumas mudanças simples nos programas do método das replicações, uma vez que os valores observados já são armazenados durante - programa Obs_Repl(). Assim, seria apenas necessário inserir um cálculo de convergência e permitir que este valor seja avaliado de modo a informar as usuário (caso a convergência não seja obtida) que ele deve reiniciar o processo com um tamanho maior de rodada.

O processo de integração ao ASiA também é bastante simples e muito parecido com os outros métodos, com a utilização de menos parâmetros $e$ variáveis auxiliares.

A técnica heurística também procura reduzir os efeitos de warm up desprezando valores iniciais, o que também foi implementado para o método das replicaçōes.

O método Bootstrap, por sua vez, trabalha com o processo de reamostragem de valores. Para ser implementado, basta que o modelo passe ao método os valores correspondentes a uma amostra e o método se encarrega de realizar a reamostragem e apresentar os resultados.

As mudanças a serem efetuadas no ASiA também são mínimas quando comparadas aos outros métodos, bastando para isso, permitir que o modelo faça a chamada ao método, introduza novos parâmetros de análise (como o tamanho da amostra, por exemplo), transfira os valores observados, armazene os resultados da análise e faça a chamada ao relatório correspondente.

\subsection{Comentários Finais}

Baseando-se nas conclusōes obtidas no capítulo anterior, foram selecionados alguns métodos de análise para implementação e integração ao ASiA. A seleção dos métodos considerou diversos aspectos, entre eles a freqüência de utilização entre os softwares do tipo do ASiA. Os métodos selecionados restringiram-se aos mais abordados na literatura da área, mas mesmo assim, analisou-se a possibilidade de inserir métodos não muito tradicionais ao ASiA. Isso vem mostrar que o ASiA está bem adequado a novas realidades dentro da área de análise de saídas.

Os métodos foram implementados de maneira a garantir a simplicidade através da padronização entre nomes de variáveis, de rotinas e de estruturas lógicas. 
É importante destacar que entre os métodos selecionados para desenvolvimento no início deste capítulo, encontram-se relacionados os procedimentos para cálculo de autocorrelação entre médias amostrais e técnicas de redução de variância. O primeiro deles foi incorporado dentro do método Batch Means e desdobrado para a análise de múltiplas variáveis. O segundo, foi incorporado no estudo feito para a inclusão do método de comparação entre dois sistemas e as estruturas de dados necessárias para ele foram inseridas no ASiA.

Como ao longo do tempo, o $\mathrm{ASiA}$ vem sofrendo várias alterações com o intuito de adequá-lo a novas situações e às novas tecnologias, a inserção de qualquer módulo à sua forma atual torna-se uma tarefa não muito simples. Sendo assim, algumas estruturas apresentadas como atuais poderão não mais sê-lo durante a leitura desta dissertação. Mas, graças à estrutura original, muito bem documentada e de fácil compreensão e à sua manutenção ao longo de todas as modificações, a inserção deste módulo vem ocorrendo de maneira natural.

A integração dos programas desenvolvidos envolveu alterações nos dois principais módulos do ASiA: o Editor Gráfico e o Gerador de Aplicações. As alterações sofridas pelo Editor Gráfico foram descritas em termos de janelas apresentadas ao usuário e dos desdobramentos internos de suas ações, devido à interface existente entre o Editor e o Gerador. Com certeza, se fossem descritas todas as alterações realmente efetuadas no Editor, muitas páginas seriam escritas a este respeito. As modificaçōes efetuadas no Gerador de aplicaçōes, ao contrário, puderam ser descritas com detalhes. 


\section{CAPÍTULO 8}

\section{Conclusões Finais}

\subsection{Introdução}

Este capítulo apresenta as conclusões deste trabalho, suas contribuições, dificuldades encontradas durante a sua realização e algumas propostas para futuras pesquisas nesta área.

Este trabalho, expôs inicialmente os principais aspectos envolvidos direta ou indiretamente em análise de saídas ( $p$. ex. : técnicas para análise de desempenho, modelagem e simulação) culminando com uma discussão exaustiva sobre a importância da Análise de Saídas em uma Simulação. Desta forma, diversas metodologias de análise foram abordadas de modo a fomecer uma base teórica consistente para este trabalho de pesquisa.

Finalmente, foram detalhadas todas as etapas necessárias à implementação do módulo, bem como algumas restrições pertinentes.

\subsection{Conclusões}

O objetivo deste trabalho é o desenvolvimento de um módulo de análise de saídas para o ASiA. Para a definição e estudo dos métodos a serem considerados neste módulo foram analisados diversos outros sistemas de simulação e os conceitos apresentados por diversos livros de simulação, dandose ênfase especial a MacDougall [MAC87].

A primeira etapa considerada neste trabalho foi o estudo de como diversos sistemas de simulação, efetuam a análise dos resultados gerados.

Deste estudo pode-se concluir que muitos sistemas de simulação deixam a tarefa de análise estatística dos resultados para o usuário, não fornecendo ferramentas de auxílio. Esta abordagem não é muito apropriada, uma vez que, em muitos casos, o usuário não é da área de simulação e portanto pode não ter os conhecimentos necessários para proceder a análise sem $\circ$ auxílio de uma ferramenta.

Considerando os sistemas que apresentam algum tipo de ferramenta, verificou-se quais métodos são utilizados em cada sistema de simulação. Com base neste estudo, foi elaborada a tabela 6.1 que mostra, entre outras informações, qual a porcentagem de sistemas que utilizam cada método.

Baseando-se neste estudo e em outros critérios definidos no capítulo 7 , foram selecionados os métodos estatísticos que serão implementados no ASiA: método das replicações para uma única variável, método Batch Means para uma única variável, método das replicações para múltiplas variáveis, método Batch Means para múltiplas variáveis e um procedimento para comparaçāo entre dois sistemas baseado na diferença entre suas médias, utilizando técnicas de redução de variância, conforme abordado em [MAC87]. Em todas as implementaçōes 
restringiu-se as variáveis às funçōes pré-definidas pelo smpl, para efeito de simplicidade. Os métodos implementados foram executados para vários exemplos.

Uma vez testados os programas criados para modelos de simulação genéricos em smpl, considerou-se a integração destes ao ambiente de simulação ASiA.

A estrutura original do ASiA, mantida apesar das diversas versōes já desenvolvidas, facilita a integração de novos módulos. A integração do módulo de análise de saídas envolve alterações nos principais módulos do ASiA (Editor Gráfico e Gerador de Aplicações) bem como a especificação de uma nova estrutura de dados utilizada para armazenar valores referentes aos métodos de análise e resultados.

Todos os métodos desenvolvidos permitem que o usuário atribua os valores que achar convenientes aos parâmetros de análise, mas aconselha-se, sempre que possivel, iniciar a análise com os parâmetros fixados pelo programa, pois eles garantem resultados coerentes, mesmo que, para a maioria dos modelos simulados, sejam considerados grandes demais.

\subsection{Dificuldades encontradas}

No que se refere à implementação dos módulos, a maior dificuldade foi garantir que os procedimentos empregados no tratamento dos métodos de análise reaimente satisfizessem à todas as exigências da teoria estatística, de forma a produzir resultados coerentes. Isso explica porque, na maioria dos métodos utilizou-se mais replicações ou mais lotes do que o necessário ou tamanhos de rodada ou de lotes maiores que o necessário. A própria limitação das variáveis analisadas às variáveis pré-definidas é um reflexo disso, pois, muito mais rica seria a análise se outras variáveis pudessem ser avaliadas com a segurança que o conhecimento estatístico permite.

No que se refere à integração, o maior problema foi o desenvolvimento de diferentes módulos para o ASiA. Para evitar maiores complicações, partiu-se neste trabalho da estrutura original do ASiA, a qual está muito bem desenvolvida e implementada, e produziu-se um estudo para a integração, com todas as etapas necessárias detalhadas, até que a redefinição do ASiA seja concluída, permitindo assim a integração definitiva. Esta redefinição já está em andamento, constituindo um novo trabalho de mestrado [PIE97].

\subsection{Contribuições deste Trabalho}

A criação do módulo de análise de saídas para o ASiA era de fundamental importância para o sistema, visto que os resultados de uma única rodada de simulação não tem grande importância e a confiabilidade nos resultados era dependente unicamente da habilidade do experimentador ao executar o modelo tantas vezes quantas ele achasse necessário para obter resultados considerados satisfatórios. 
Os métodos desenvolvidos tornam o ASiA um aplicativo de uso mais amplo e cujos resultados podem efetivamente servir a algum propósito, como comparar o desempenho de dois sistemas, por exemplo.

Além disso, uma vez realizada uma simulação utilizando os métodos de análise, os resultados obtidos poderão ser utilizados de diversas maneiras e em diversos tipos de avaliação, com um nível de precisão pré-determinado.

Este módulo de análise contribui para que o ASiA atinja um de seus principais objetivos básicos que é a de ser um ambiente de simulação de uso bastante geral e não voltado apenas a especialistas em simulação e em estatística.

Uma contribuição adicional deste trabalho é o estudo da utilização de métodos estatísticos para análise de resultados em diversos sistemas de simulação, apresentando uma pesquisa sobre os métodos mais empregados nos sistemas da atualidade e apresentando também outros métodos, que embora não sejam empregados pelos sistemas de simulação analisados, possam vir a se tornar muito úteis na análise de resultados, pela facilidade de automatização e pela economia de tempo de execução da simulação.

\subsection{Sugestões para trabalhos futuros}

Esta implementação inicial dos métodos de análise sugere diversos melhoramentos. O primeiro deles parece ser a própria apresentação dos resultados durante a execução da simulação. $O \mathbf{s m p l}$ oferece o recurso trace para solucionar este problema, mas a própria implementação dos métodos fornece infra-estrutura para um processo mais bem elaborado.

Em segundo lugar, um possivel melhoramento seria expandir o método de análise para diversas variáveis de interesse, sem as restrições impostas por esta implementação. Como foi dito anteriormente, isso não é uma tarefa muito fácil, uma vez que requer conhecimentos estatísticos mais aprofundados para dar fundamento às técnicas utilizadas.

Um outro melhoramento poderia ser a inclusão de técnicas mais recentes na área de análise de saídas, técnicas mais simples e que garantam resultados convincentes através de um tempo menor de simulação.

Finalmente, a flexibilidade do $\mathrm{ASiA}$ em relação à integração destes métodos provou ser possível adaptá-lo aos mais diversos métodos de análise e isso sugere que ele seja expandido para outras áreas de interesse dentro do campo da simulação. 


\section{Bibliografia}

[ADA83] ADAM, N. R.; Achieving a Confidence Interval for Parameters Estimated by Simulation; "Management Science", 29:7, 856-866, 1983.

[BAN96] BANKS, J.; Output Analysls Capabilitles of Simulation Software; "Simulation", 66:1, 23-30, 1996.

[BEL87] BELL, P.C.; O'KEEFE, R.M.; Visual Interactive Simulation - History, Recent Developments and Major Issues, Simulation, 49(3), 109-116, 1987.

[BER94] BERNASCONI, G.C.R.; Números Aleatórios Antitéticos: Uma Comparação com os Resultados usuais em Slmulação; Dissertação de Mestrado, Universidade de São Paulo, 1994.

[BYR87] BYRKIT, D.R.; Statistic Today - A comprehensive introduction; The Benjamin/Cummings Publishing Company, Inc., Menlo Park, Califórnia, 1987.

[CYR95] CYRE, W.R.; Generating Simulation Models from Natural Language Specifications; "Simulation", 239-250, 1995.

[EFR93] EFRON, B.:TIBSHIRANI, R.J.; An Introduction to the Bootstrap; Chapman \& Hall, 1993.

[FER92] FERNANDES, M.; Modelagem Analítica de Desempenho de Sistemas Multiprocessadores: Aplicação ao Multiprocessador CPER; Dissertação de Mestrado, Universidade Federal de São Carlos, 1992.

[FRI95] FRIEDMAN, L.W.; FRIEDMAN, H.H.; Analyzing Simulation Output Using the Bootstrap Method; "Simulation",95-100, 1995.

[FUN91] FUNKA-LEA, C.A. et al.; Interactive Visual Modeling for performance, IEEE Software, 8(5), 58-68, 1991.

[GRO85] GROSS, D; HARRIS, C. M.; Fundamentals of Queuelng Theory; $2^{\mathrm{a}}$ Ed., New York, John Wiley, 1985.

[HAR88] HARKER, S.; The Use of Prototyping and Simulation in the Development of Large-Scale Applications; "The Computer Journal", 31(5), 1988.

[KLE87] KLEIJNEN, J. P. C.; Statistical Tools for SImulation Practicioners; Marcel Dekker, Inc., 1987.

[KOB81] KOBAYASHI, $\mathrm{H}_{\text {.; }}$ Modeling and Analysis - An Introduction to System Performance Evaluation Methodology; Addison Wesley Publishing Company, 1981. 
[LAW79] LAW, A. M.; CARSON, J. S.; A Sequential Procedure for Determining the Lenght of a Steady State Simulation; "Operation Research", 27, 1011$1025,1979$.

[LUK86] LUKER, P. A.; Program Generators and Generation Software; "The Computer Journal", v.29, n.4, 315-321, 1986.

[MAC75] MACDOUGALL, H.;System Level Simulation - Digital System Design Automatlon: Languages, Simulation Data Base; Computer Science Press, 1975.

[MAC87] MACDOUGALL, H.;Simulation Computer Systems - Techniques and Tools; The MIT Press, 1987.

[MAR91] MARCUS, A.; van DAM, A.; User-Interface Developments for the Ninetles; "IEEE Computer", v.24, n.9, 49-57, 1991.

[MIT92] MITRANI, I.;Simulation Techniques For Discrete Event Systems; Cambridge University Press, 1992.

[MUN95] MUNTZ, R. R.; Performance Measurement and Evaluation; "Encyclopedia of Computer Science", 3 Ed., 1995.

[NAI95] NAIK, V.K.; Performance of NAS Parallel Benchmark LU on IBM SP Systems; IBM Research Division, RC 20046, 1995.

[ODO83] ODONI, A. R.; ROTH, E.; An Empirical Investigation of the Transient Behaviour of Stationary Queueing Systems; "Operation Research", 31, 432-455, 1983.

[ORL95] ORLANDI, R. C. G. S.; Ferramentas para Análise de Desempenho de Sistemas Computacionais Distribuídos; Dissertaçāo de Mestrado, Universidade de São Paulo, 1995.

[OZD91] OZDEN, M. H.; Graphical Programming of Simulation Models in ObjectOriented Environment, Simulation, 56(2), 104-116, 1991.

[PAW90] PAWLIKOWSKI, K.; Steady-State Simulation of Queueing Process: A Survey of Problems and Solutions; "ACM Computing Surveys", 22(2), 123$170,1990$.

[PEG91] PEGDEN, C. D.; SHANNON, R. E.; SADOWSKI, R. P.; Introduction to Simulation Using SIMAN; MacGraw Hill Internations Editions, 1991.

[PID92] PIDD, M.; Computer Simulation in Management Science; $3^{a}$ Ed.,John Wiley \& Sons, 1992.

[PIE97] PIEKARSKI, A. E. T.; Redefiniçāo dos Processos do Ambiente de Simulação Automático (ASiA); Mini-Dissertação de Mestrado, Universidade de São Paulo, 1997. 
[RAC90] RACZYNSKI, S.; Graphical Description and a Program Generator for Queueing Model, Simulation, 55(3), 147-152, 1990.

[ROT95] ROTH, P. F.; Simulation; "Encyclopedia of Computer Science", 3"Ed., 1995.

[SAN94] SANTOS, C. A.; Análise de Comprimento de Simulação Através do Procedimento de Law e Carson; Dissertaçāo de Mestrado, Universidade de São Paulo, 1994.

[SAN94a] SANTANA, R. H. C.; SANTANA, M.; ORLANDI, R.; SPOLON, R.; CALONEGO, N.; Técnicas para Avaliação de Desempenho de Sistemas Computacionais, Notas Didáticas do ICMSC, USP, 1994.

[SAR84] SARGENT, R. G.; A Tutorial on Verification and Validation of Simulation Models; "Proceedings of the 1984 Winter Simulation Conference", 115-121, 1984.

[SHI75] SHIMIZU, T.; Simulação em Computador Digital; Editora Edgard Blücher Ltda, 1975.

[SOA92] SOARES, L.; Modelagem e Simulação Discreta de Sistemas; Editora Campus, 1992.

[SPI78] SPIEGEL, M. R.; Probabilidade e Estatística; McGraw-Hill do Brasil Ltda, 1978.

[SPO94] SPOLON, R.; Um Gerador de Aplicação para um Ambiente de Simulação Automático; Dissertação de Mestrado, Universidade de São Paulo, 1994.

[SPO94a] SPOLON, R.; Um Editor Gráfico para um Ambiente de Simulação; Dissertação de Mestrado, Universidade de São Paulo, 1994.

[SWA95] SWAIN,J.J.; Simulation Survey: Tools for Process Understanding and Improvement; "OR/MS Today", 64-79, Agosto/1995.

[TAN88] TANEMBAUM, A.S.; Computer Networks, Englewood Cliffs, N. J., Prentice Hall, 1988.

[THE94] THEKKATH, C. A.; Techniques for File System Simulation; "Software Practice and Experience", Vol. 24(11), 981-999, 1994.

[TOC63] TOCHER, K. D.; The Art of Simulation; English University Press, London, 1963.

[WEl90] WEICKER, R. P.; An overview of Common Benchmarks; IEEE Computer, $65-75,1990$.

[WOL95] WOLPERT, D.H.; The Bootstrap is Inconsistent with Probability Theory; "Maximum Entropy and Bayesian Methods", 1995. 


\section{Listagem dos Códigos-fonte dos programas do Módulo de Análise de Saídas}

\section{A.1 Programas referentes ao Módulo de Análise}

\section{A.1.1 Programa Repl.c}

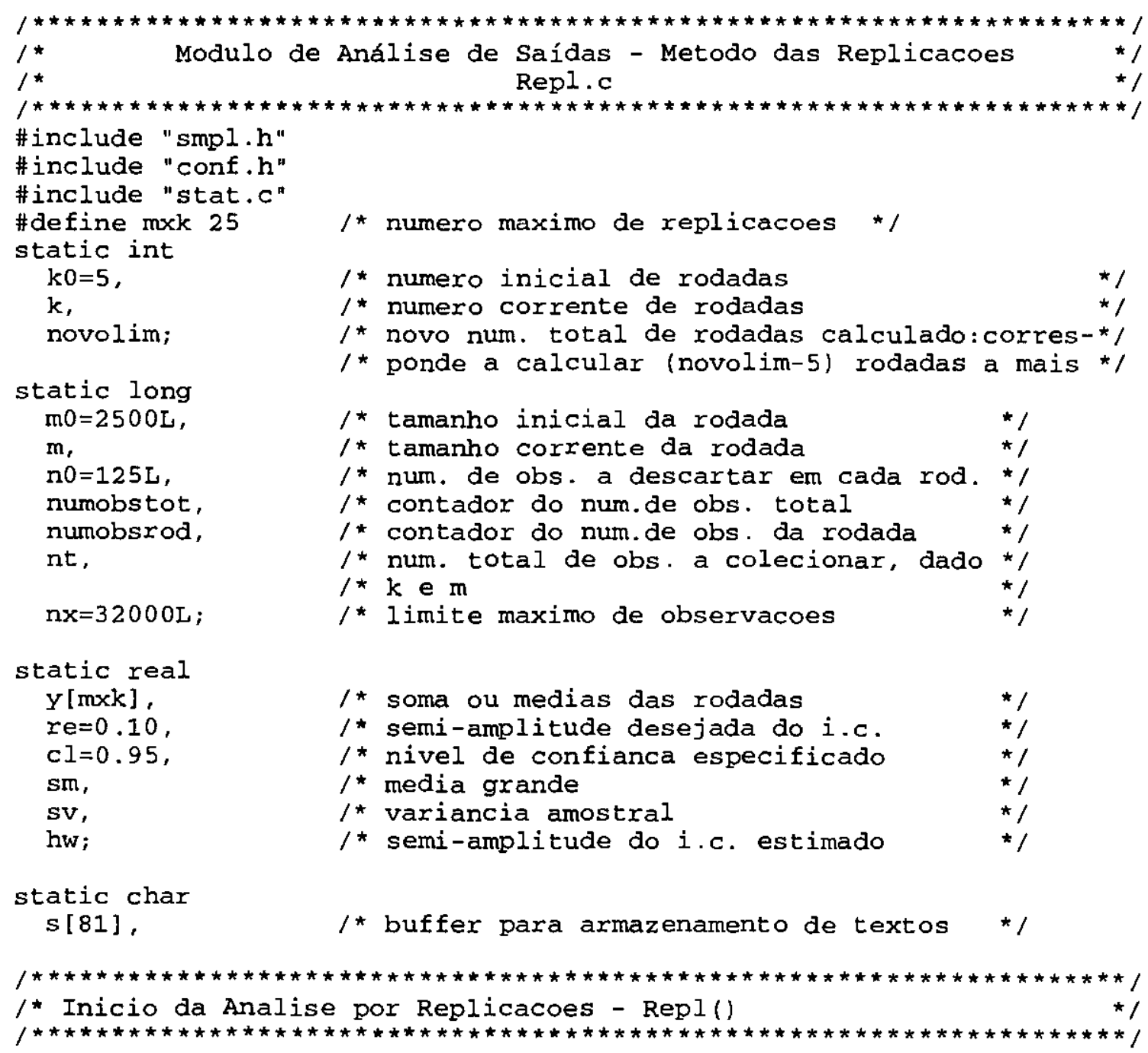

void Repl()

l

/* A analise das saidas da simulacao e iniciada a partir do */

1* modelo de simulacao a partir da chamada a esta funcao. $0 * /$

/* valor amostral a ser analisado sera definido no modelo, mas */

/* ficara restxito aos parametros SMPL, a saber: U(f), Lq(f) $e$ */

/* $B(f)$ e cada observacao sera acumulada atraves da chamada do * /

/* modelo a funcao Obs_Repl(). Os parametros de analise, tais */

/* como a precisao desejada sao definidos dentro desta funcao, */

/* mas podem ser alterados pelo usuaxio atraves da funcao */

/* Define_Par_Repl(), cuja chamada ocorre dentro do modelo */ 


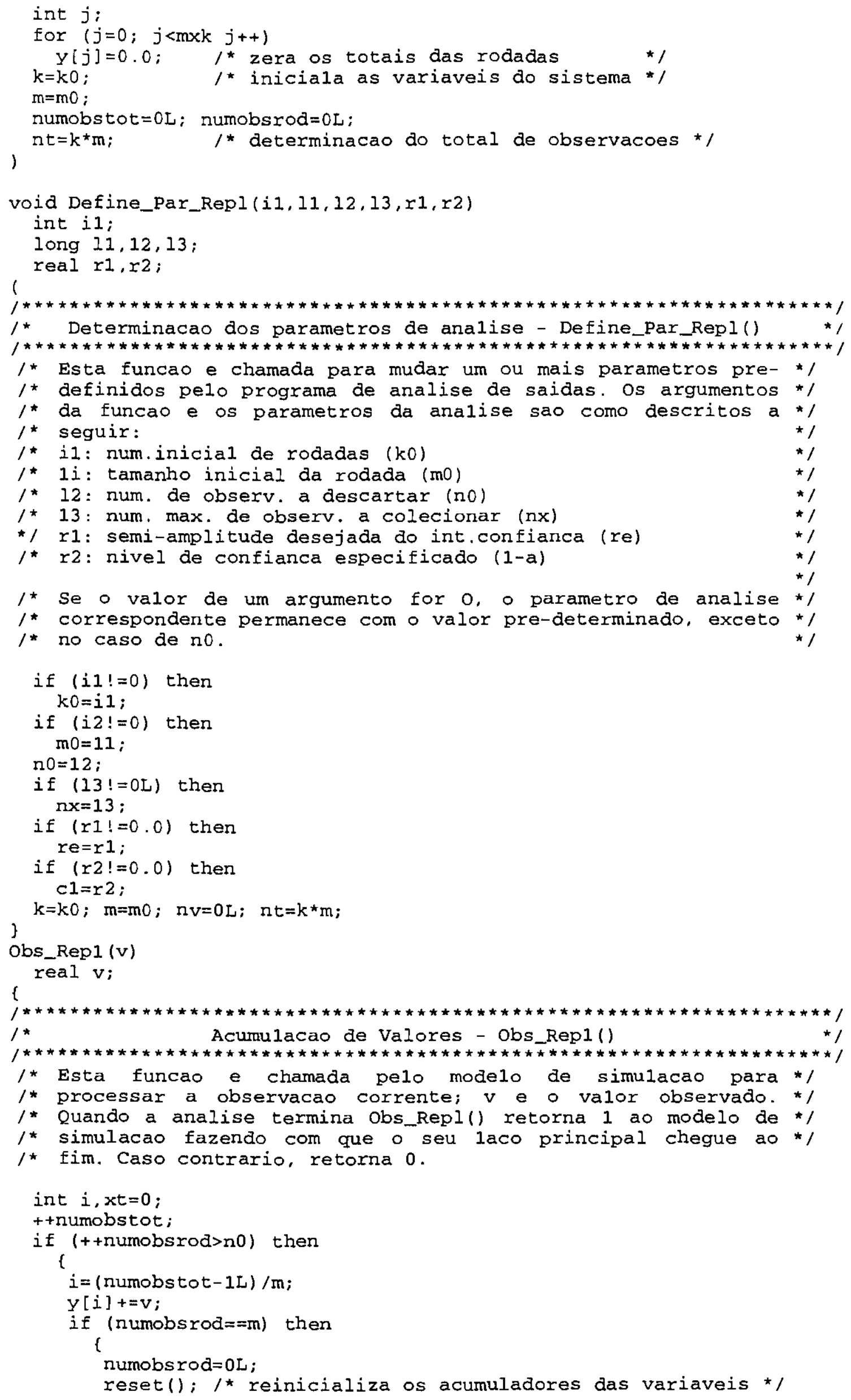




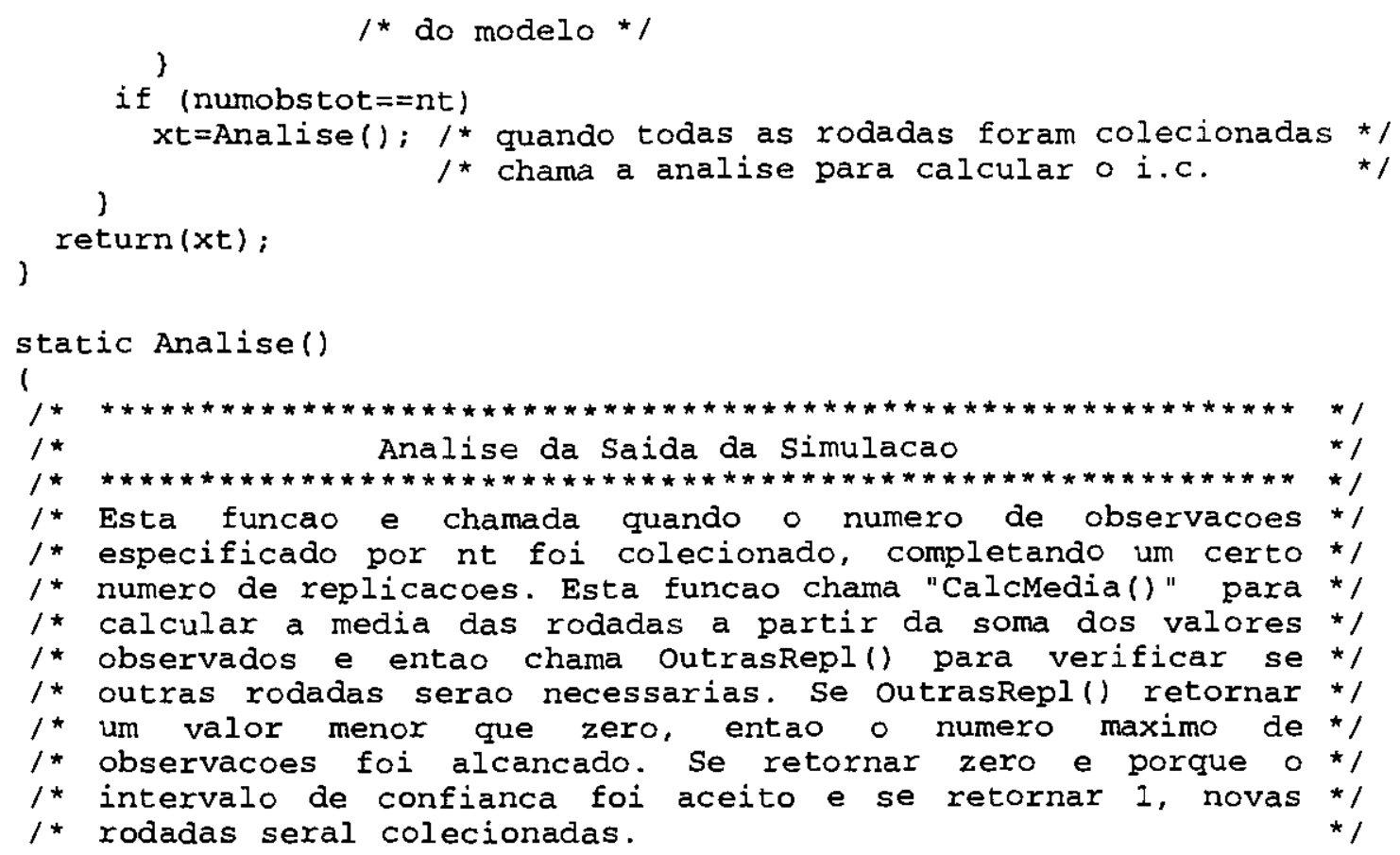

int $\mathrm{xt}=0, \mathrm{r}$;

CalcMedia();

$r=$ outrasRepl ();

if $(r==0)$ then $x t=0 ; l^{*}$ a analise termina - objetivo atingido * /

if $(r<0)$ then $x t=-1 ; I^{*}$ a analise tambem termina - sem atingir seu objetivo */ ) return (xt);

static OutrasRepl()

f

1

$1 *$

$1 *$

$1 *$

$/ \star$

$1 *$

$1 *$

$/ \star$

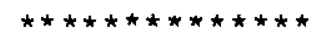

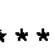

int $r e j=0$;

long $n$;

/* Obtem a semi-amplitude do i.c. estimado */

SemiAmpl ();

if $\left(\mathrm{hw}>\mathrm{re}^{*} \mathrm{sm}\right)$ then

rej=1; /* Intervalo de Confianca rejeitado */

if $(r e j==1)$ then

i

if $(k>=m \times k)$ then

i

1* a coleta de uma nova rodada vai exceder o numero maximo */

/* de rodadas; informa ao usuario para dobrar o tamanho */

$/ *$ inicial da rodada */ )

printf("Reinicie com tamanho da todada igual a $81 d ", 2{ }^{\star} \mathrm{m}$ );

if ( $($ rej=VerLimite()!=-1) then

(

/* Se uma rodada adicional pode ser colecionada sem exceder */

/* o limite especificado de observacoes... */

$\mathrm{k}=$ novolim; 


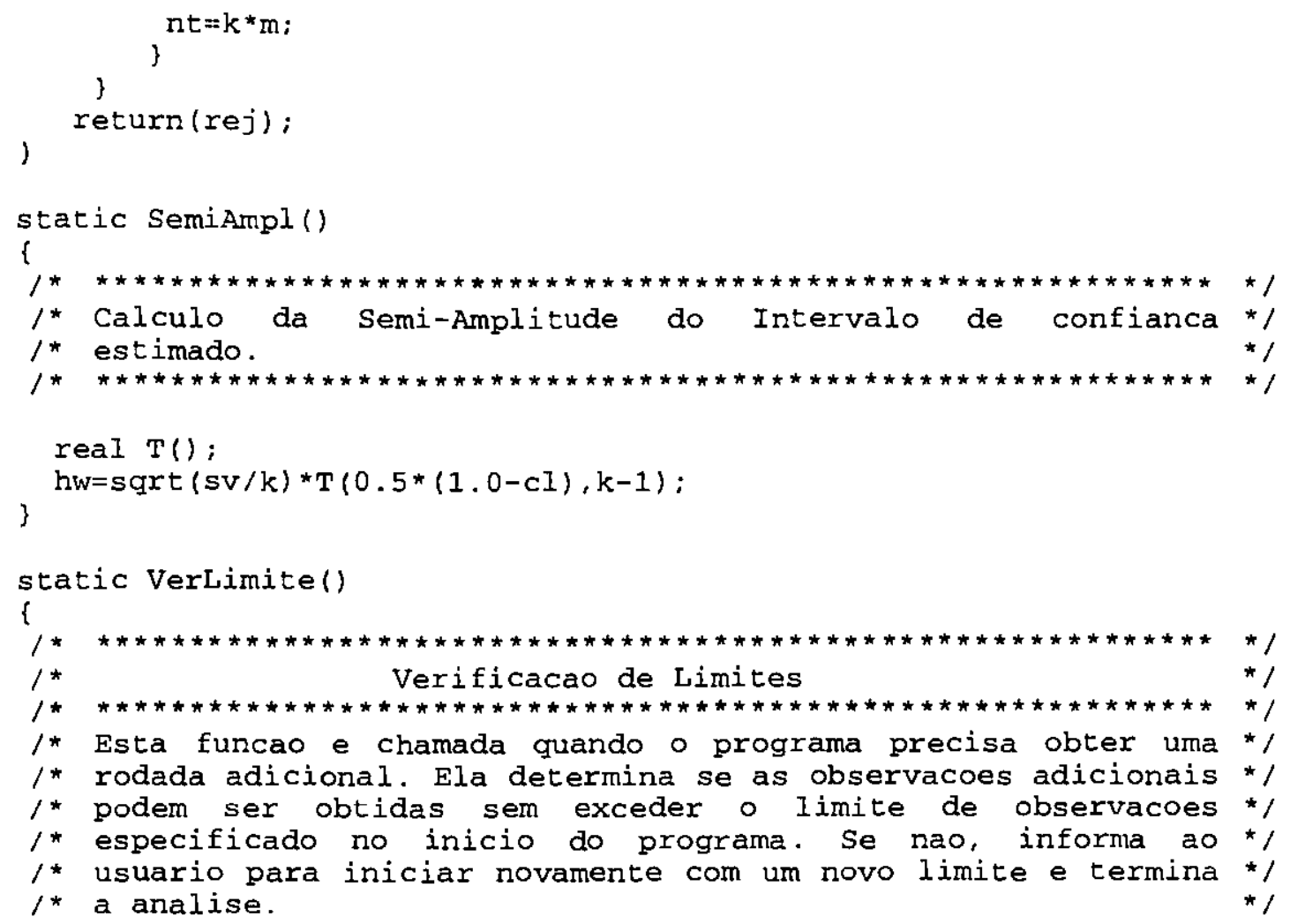

Obtem_Result_Repl(nlr,m,mg,sa) 


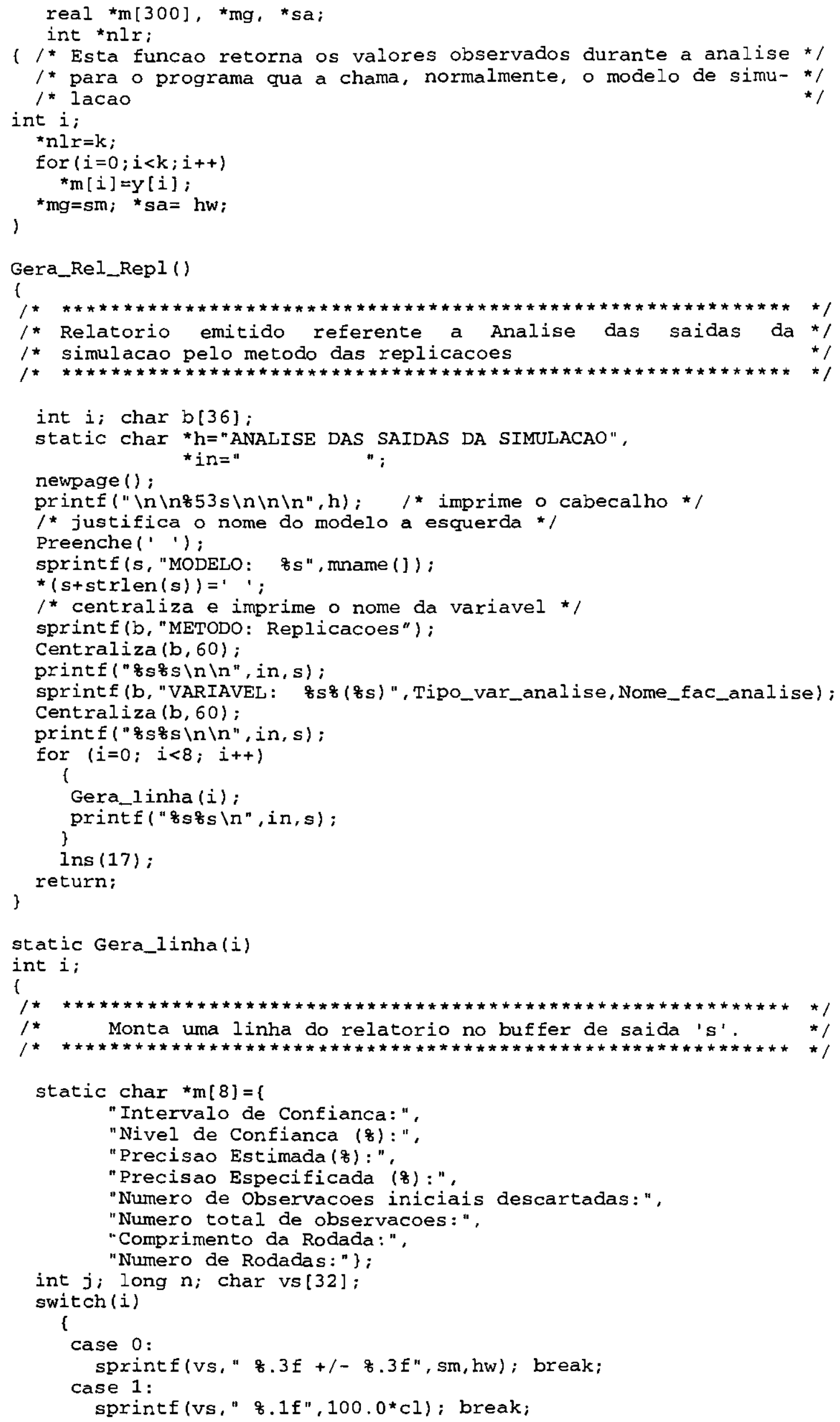




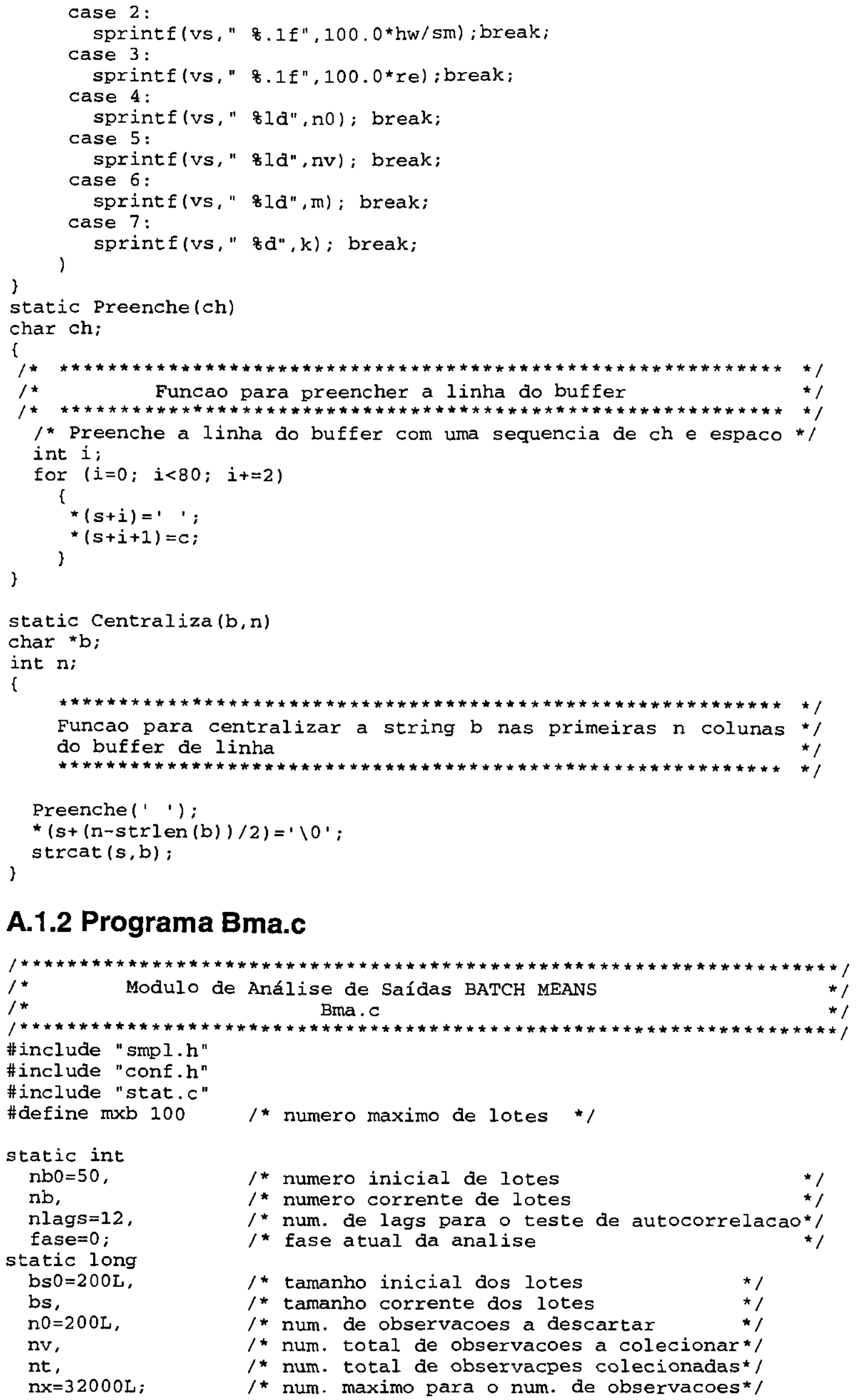

A.1.2 Programa Bma.c 
$y[m \times b]$,

$r e=0.10$,

$c l=0.95$,

$\mathrm{al}=0.05$,

sm,

sv,

hw:

static char

s[81],
1* soma dos lotes ou media

/* semi-amplitude do i.c. desejada

/* nivel de confianca especificado

/* nivel de significancia p/autocorrel. */

/* media grande

/* variancia das medias dos lotes

/* semi-amplitude estimada

$\star 1$

$\star /$

/* buffer para armazenamento de textos */

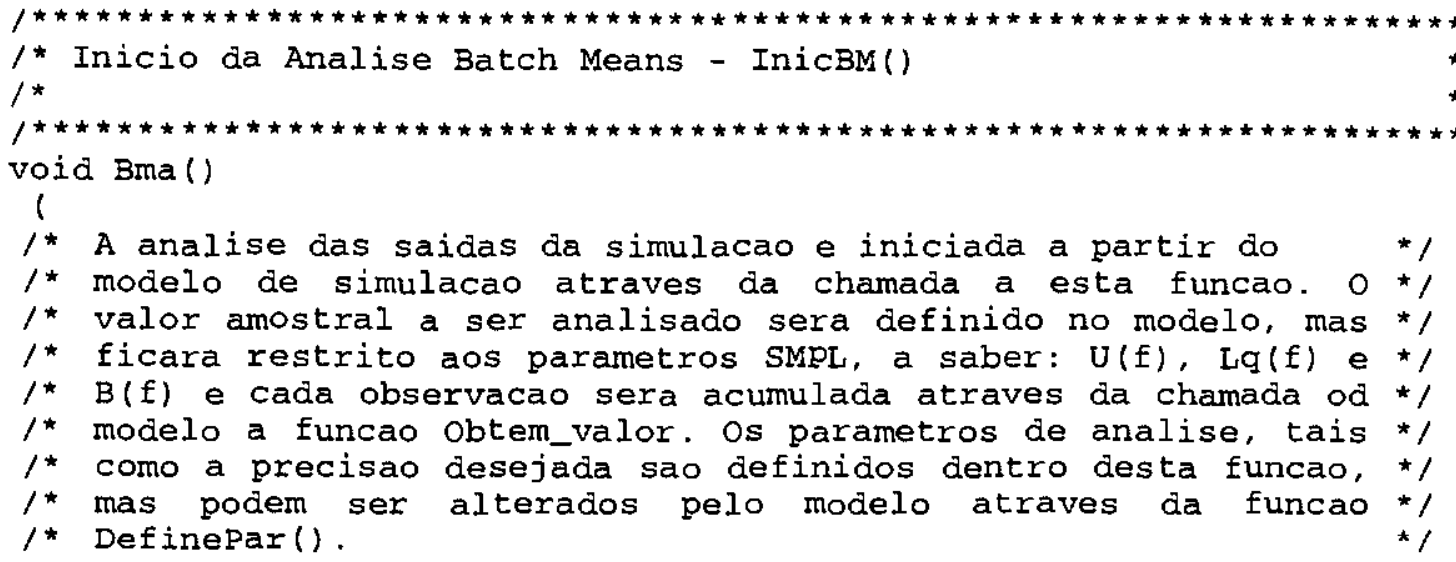

int $j$;

fase $=1 ; \quad / *$ procurando o tamanho do lote *

for $(j=0 ; j<m \times b ; j++)$

$y[j]=0.0 ; \quad / *$ inicializacao dos totalizadores dos lotes *

$\mathrm{nb}=\mathrm{nb0}$; $\quad /$ * inicializacao do numero de lotes */

bs=bs0; $\quad 1$ * inicializacao do tamanho do lote */

$\mathrm{nv}=\mathrm{OL}$; $\quad /$ * inicializacao do total de obs. colecionadas * 1

\}

$\mathrm{nt}=\mathrm{nb}$ *bs $+\mathrm{no} ; \quad /$ * determinacao do total de observacoes * $/$

void Define_par_Bm(i1,i2,11,12,13,r1,r2, r3)

int i1,i2;

long $11,12,13$;

real $r 1, r 2, r 3$;

I

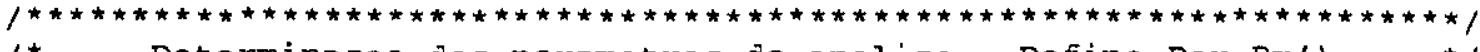

$1 *$ Determinacao dos parametros de analise - Define_Par_Bm() *

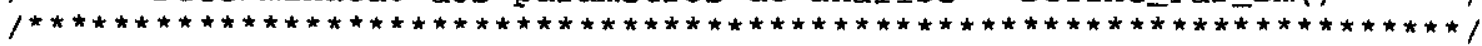

/* Esta funcao e chamada para mudar um ou mais parametros */

/* padrao da analise de saidas. Os argumentos tem o seguinte */

/* significado:

/* i1: num.de lotes (nb0) - deve ser par

/* i2: num. de lags (nlags)

1* 11: tamanho inicial do lote (bs0)

/* 12: num. de observ. a descartar (n0)

/* 13: num. max. de observ. a colecionar (nx)

* rl: semi-amplitude desejada do int.confianca (re)

/* r2: nivel de confianca especificado (1-a)

/* r3: nivel de significancia (al)

$1 *$ Se o valor de um argumento e 0 , o parametro de analise */

/* correspondente permanece com o valor atribuido por default, */

$/$ * exceto no caso de no. 1 


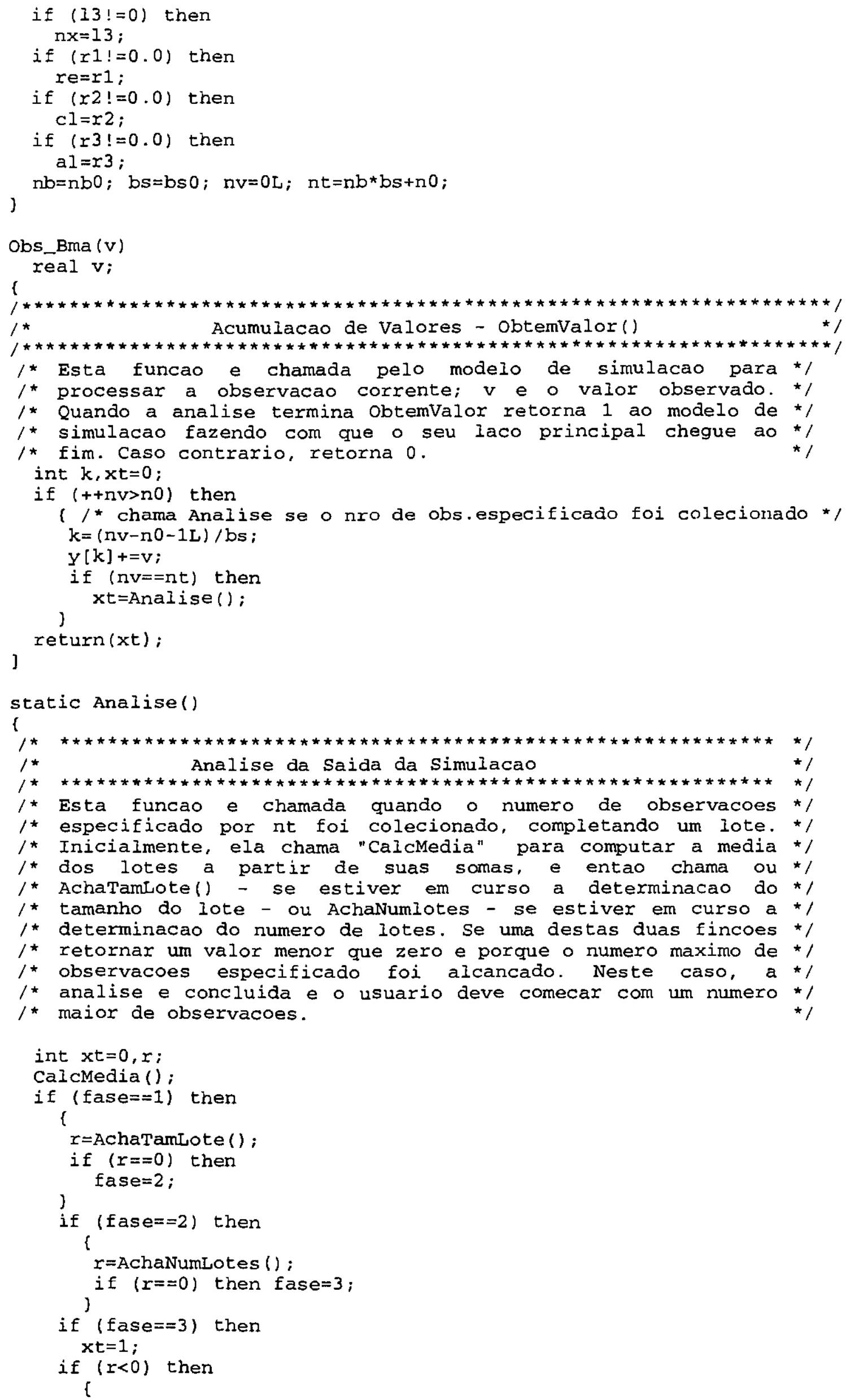




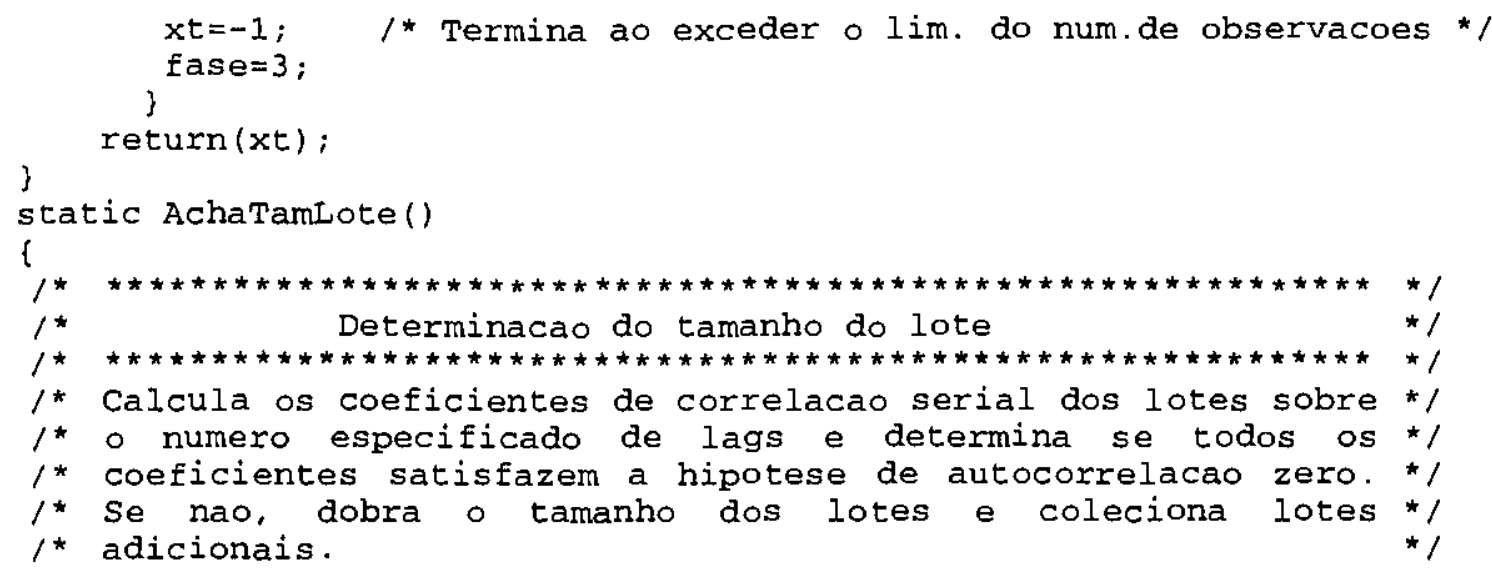




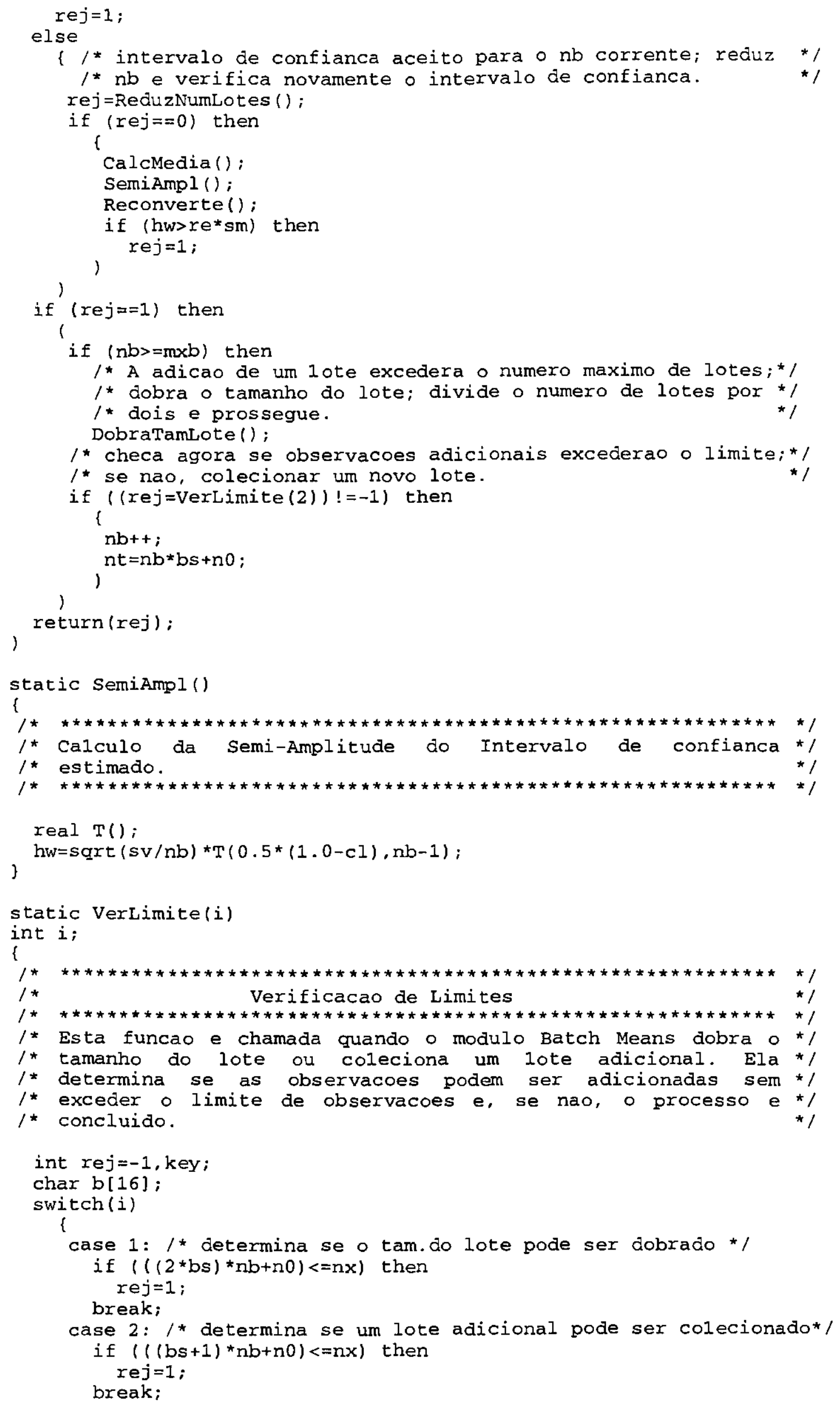




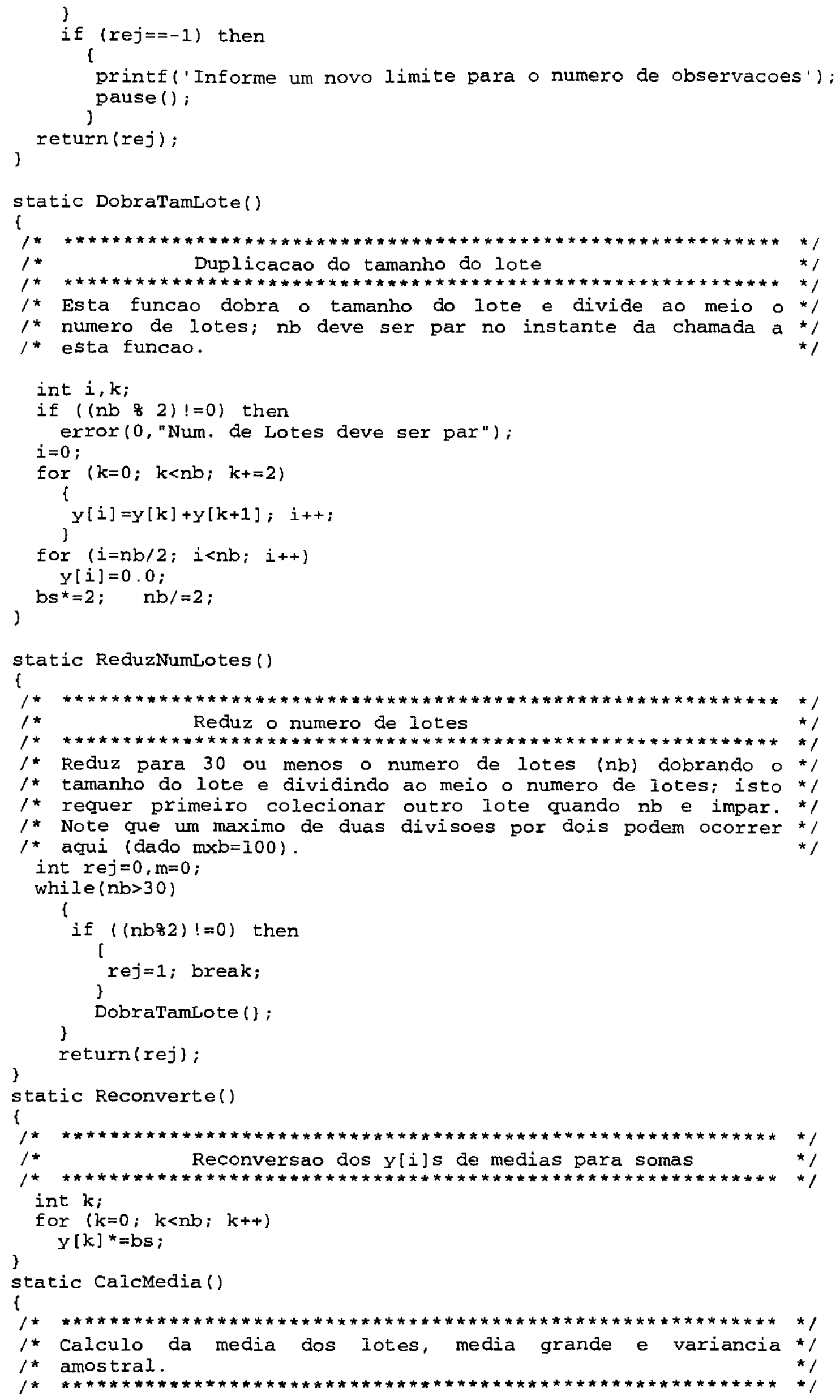


$\{1 *$ Notar que os $y[i] ' s$ sao convertidos de somas de lotes para $/$

/* media de lotes.

int $k$; real $w$;

$\mathrm{sin}=0.0$;

for $(k=0 ; k<n b ; k++)$

,

)

$y[k] /=b s ; s m+=y[k] ;$

$\mathrm{sm} /=\mathrm{nb}$;

$s v=0.0$;

for $(k=0 ; k<n b ; k++)$

\{

)

$w=y[k]-s m ; \quad s v+=w^{*} w ;$

$\mathrm{sv} /=\mathrm{nb}$;

J

static real $r(1)$

int 1 ;

\{

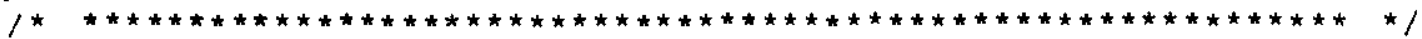

/* Calculo do 1-esimo lag dos coeficientes de autocorrelacao $* /$

$1 *$ amostral

$/ \star$

int $k$; real $w=0.0$;

for $(k=0 ; k<(n b-1) ; k++)$

$w+=(y[k]-s m) *(y[k+1]-s m)$;

)

return $\left(w /\left(n b^{\star} s v\right)\right)$;

Obtem_Result_Bm(nlr,m,mg,sa)

real *nc, *pe, *m[300], *mg, *sa;

int ${ }^{*} n l r$;

\{ /* Esta funcao retorna os valores observados durante a analise */

/* para o programa qua a chama, normalmente, o modelo de simu- */

1* lacao

int i;

*nlr=nb;

for $(i=0 ; i<n b ; i++)$

* $m[i]=y[i]$;

)

${ }^{\star} \mathrm{mg}=\mathrm{sm} ;{ }^{\star} \mathrm{sa}=\mathrm{hw}$;

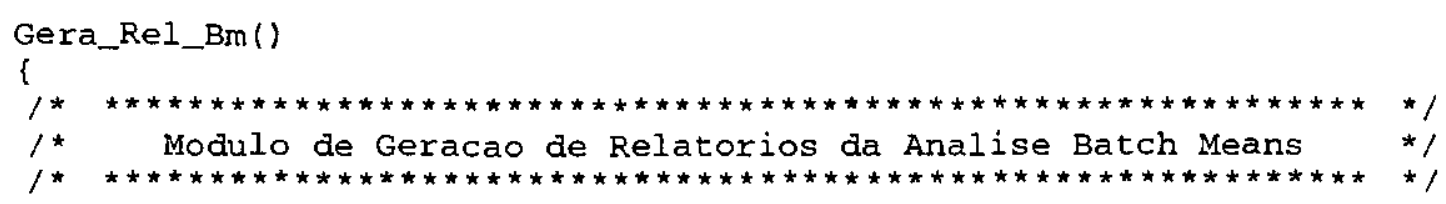

int i; char b[36];

static char * $h="$ ANALISE DAS SAIDAS DA SIMULACAO",

newpage () ;

*in=" ";

printf(" $\ln \backslash n$ \&53s $\ln \backslash n \backslash \mathrm{n} ", \mathrm{~h}) ; \quad$ * imprime o cabecalho */

/ justifica $\circ$ nome do modelo a esquerda */

Preenche(' '):

sprinte (s, "MODELO: \&s", mname()) :

$\star(s+s t r l e n(s))='$ ' ;

/* centraliza e imprime o nome da variavel */

sprintf (b, "METODO: Batch Means");

printf ("zsos $\sin \backslash n$ ", in, s);

sprintf (b, "VARIAVEL: के́s (

Centraliza $(b, 60)$;

printf("zsos $\backslash \mathrm{n} \backslash \mathrm{n} "$, in, s); for $(i=0 ; i<8 ; i++)$

\{

Gera_linha (i) ; 


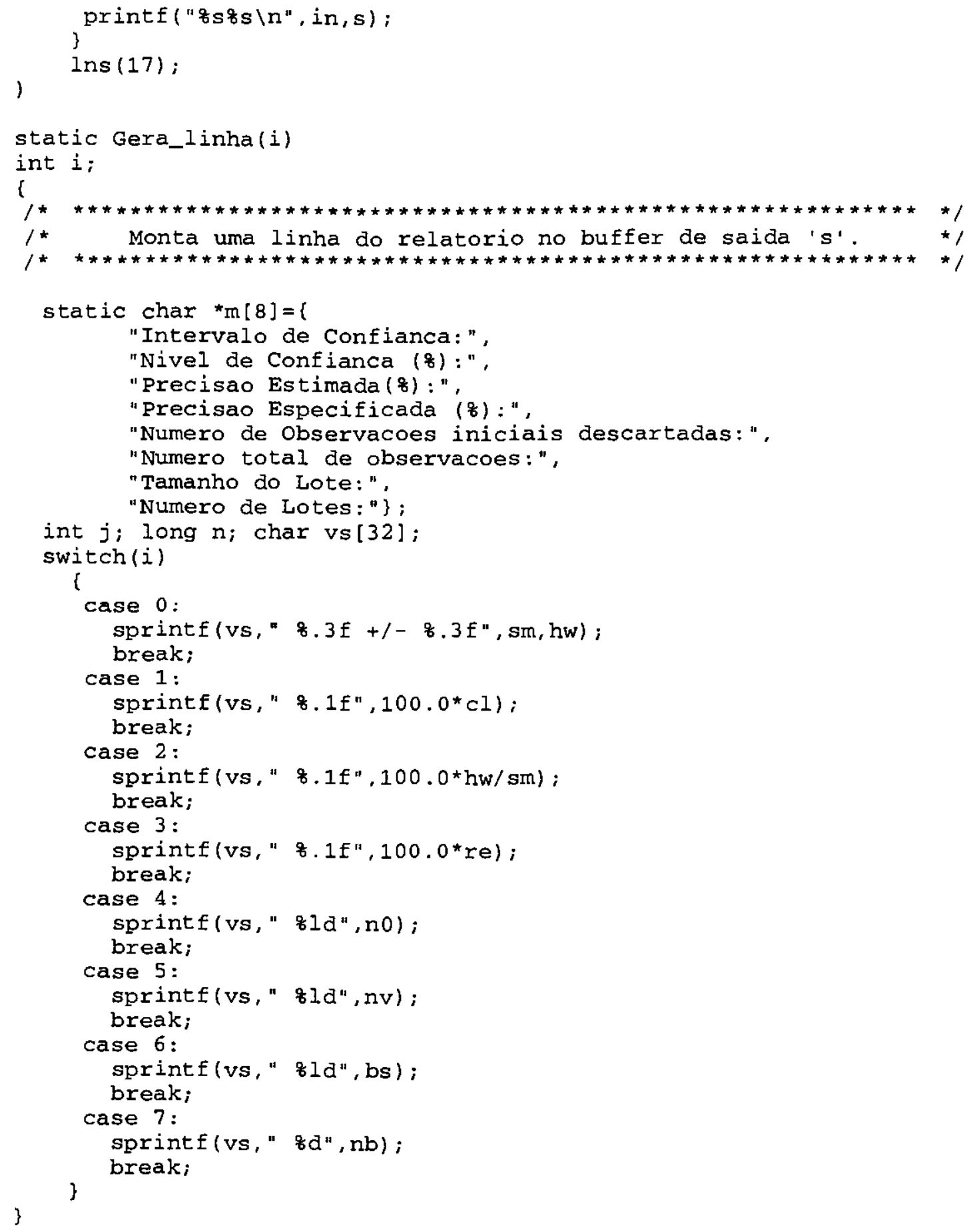

\section{A.1.3 Programa RepIMV()}

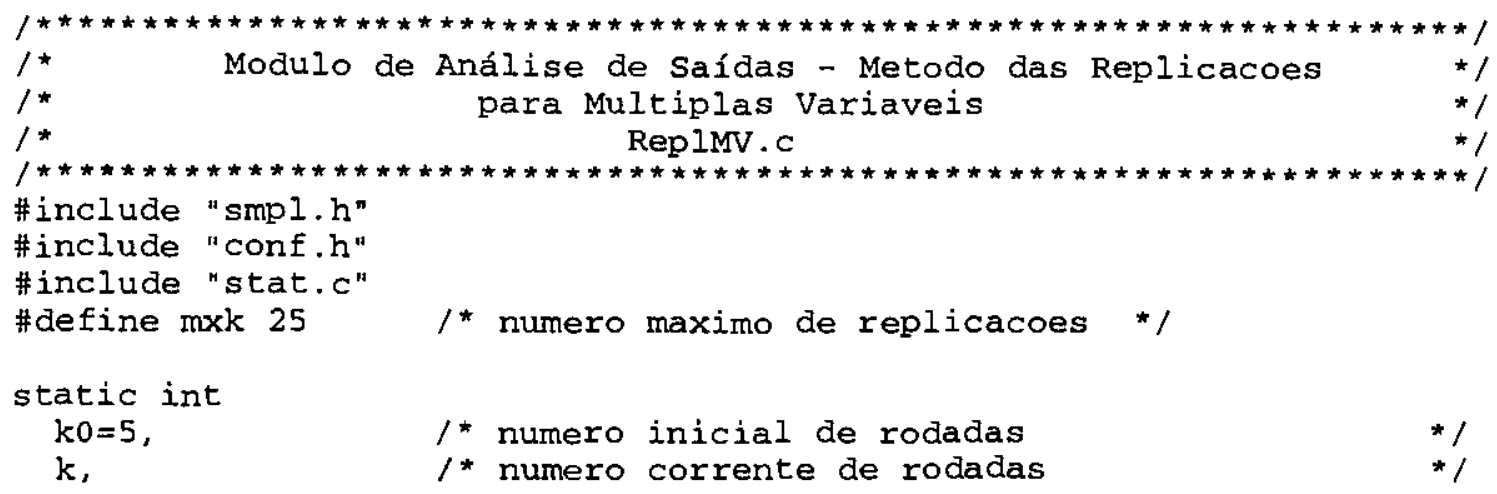




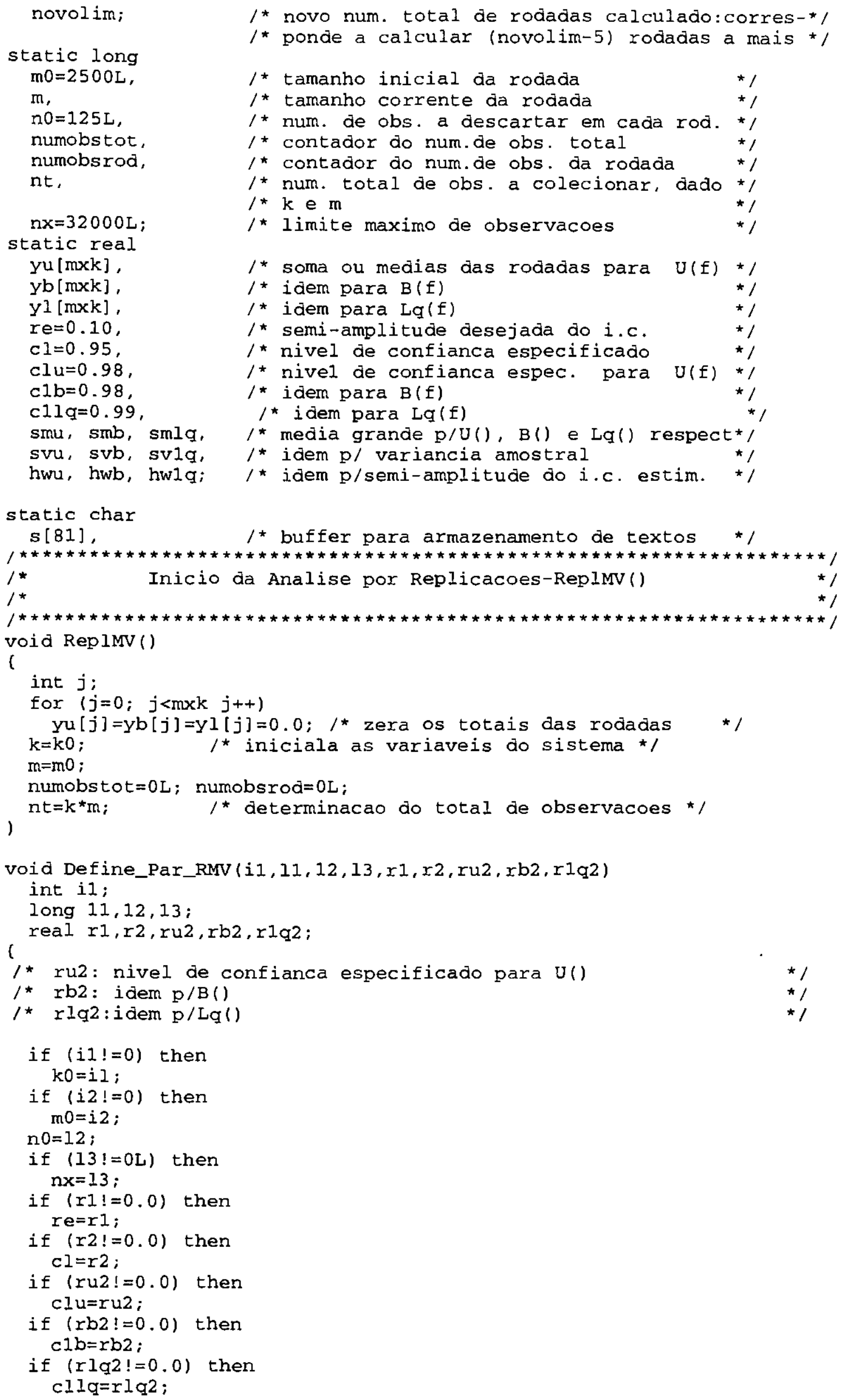


Obs_Repl_MV (v1,v2,v3)

\{

real v1, v2, v3;

int $i, x t=0$;

++ numobstot;

if $(++$ numobsrod $>n 0)$ then

\{

$i=($ numobstot $-1 \mathrm{~L}) / \mathrm{m}$;

yu[i]+=v1; yb[i]+=v2; y1[i]+=v3;

if (numobsrod $==m$ ) then

\{

numobsrod $=0 \mathrm{~L}$;

reset (1); / reinicializa os acumuladores das variaveis */

/* do modelo */

了

if (numobstot $==n t$ ) $\mathrm{xt}=$ Analise(); /* quando tođas as rođadas foram colecionađas */ )

$\operatorname{return}(x t) ;\}$

static Analise() /* identico ao similar em Repl.c */

static OutrasRepl()

\{

int $r e j=0$;

long $\mathrm{n}$;

/ Obtem a semi-amplitude do i.c. estimado */

SemiAmp 1();

if $\left(\left(h w u>r e^{*} s m u\right)||\left(h w b>r e^{*} s m b\right)||\left(h w l q>r e^{*} s m l q\right)\right.$ ) then

rej:=1; $/$ * Intervalo de Confianca rejeitado */

if $(r e j==1)$ then

\{

if $(k>=m x k)$ then

l

I* a coleta de uma nova rođada vai exceder o numero maximo */

/* de rodađas; informa ao usuario para dobrar o tamanho */

/ * inicial da rodada */

printf("Reinicie com tamanho da tođađa igual a $81{ }^{4} ", 2 * m$ ); \}

if ( (rej=VerLimite ()$!=-1)$ then

$\ell$

/* Se uma rođađa ađicional pode ser colecionada sem exceder */

/* o limite especificado de observacoes... */

了 )

return(rej);

)

static SemiAmpl()

$\ell$

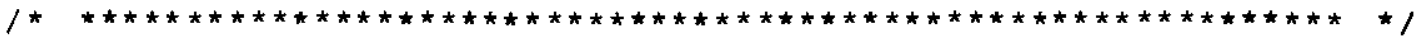

1* Calculo da Semi-Amplitude do Intervalo de confianca*/

$1 *$ estimado.

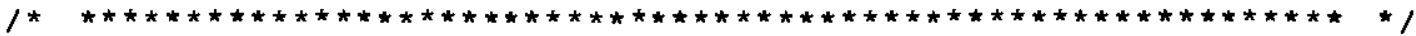

real $T()$;

hwu=sqrt $(\mathrm{svu} / \mathrm{k}) * \mathrm{~T}(0.5 *(1.0-\mathrm{clu}), \mathrm{k}-1)$;

$\mathrm{hwb}=\operatorname{sqrt}(\mathrm{svb} / \mathrm{k}) * \mathrm{~T}(0.5 *(1.0-\mathrm{clb}), \mathrm{k}-1)$;

hwlq=s grt $(\mathrm{svlq} / \mathrm{k}) * \mathrm{~T}(0.5 *(1.0-\mathrm{cllq}), \mathrm{k}-1)$;

)

static VerLimite() 


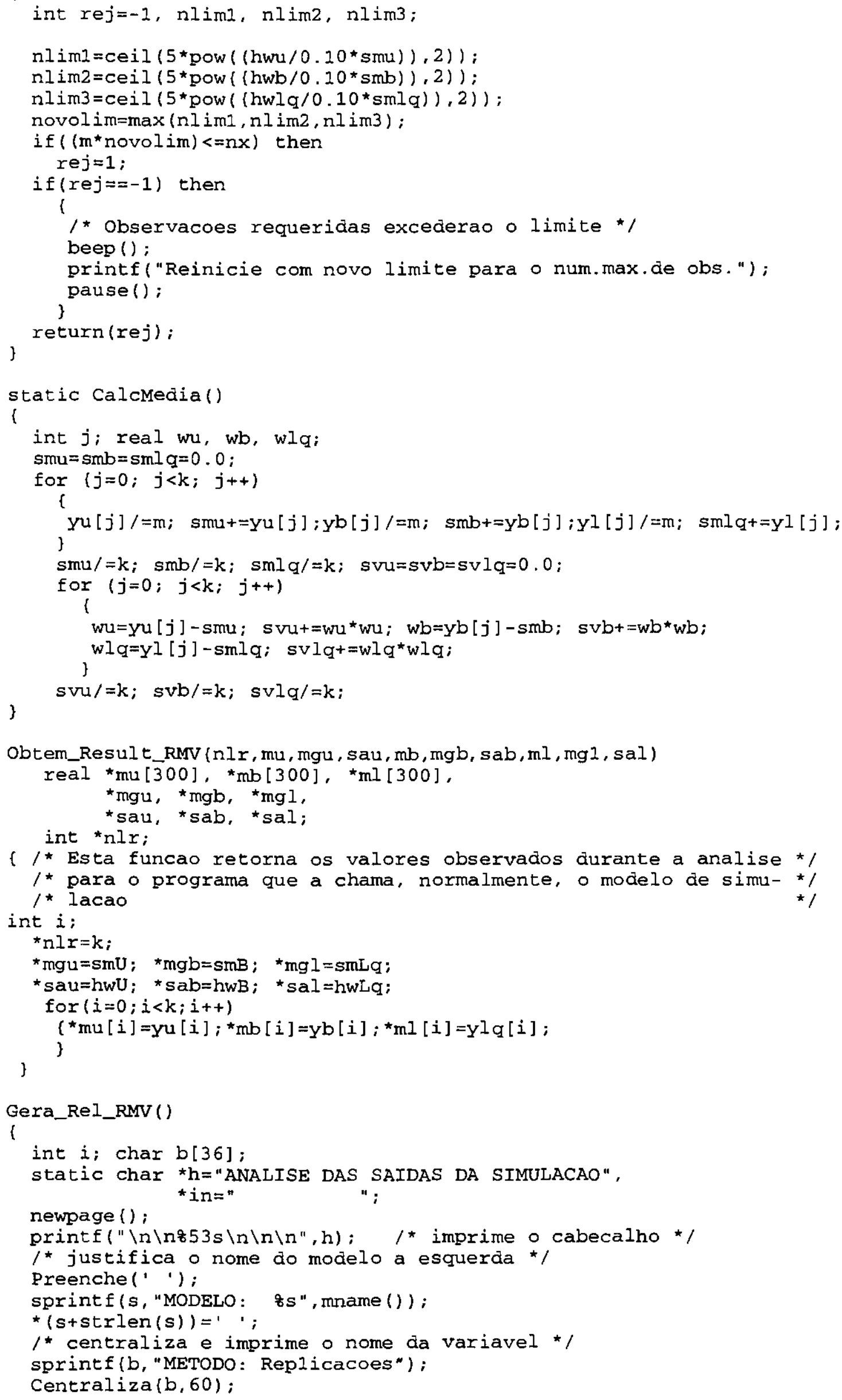




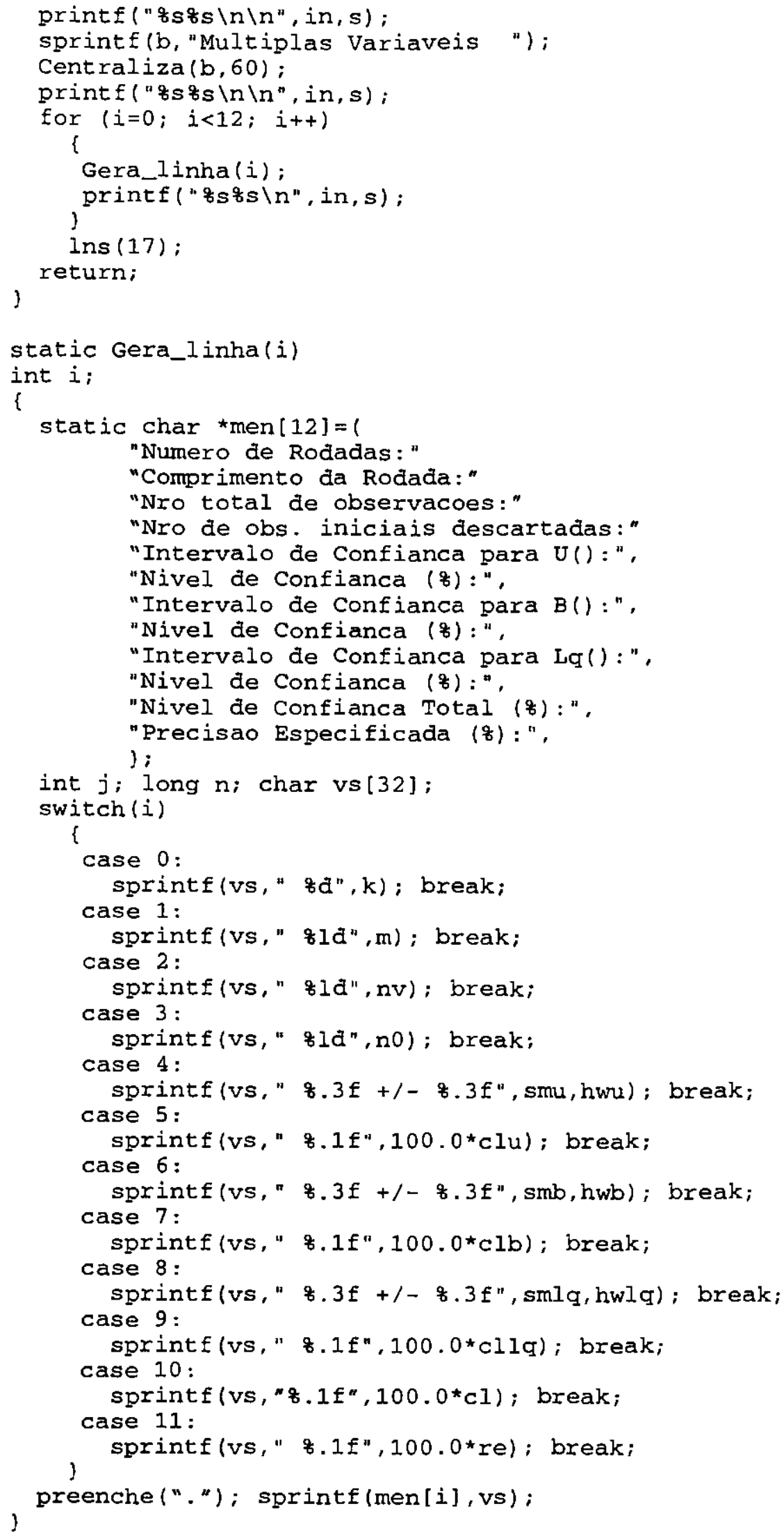

\section{A.1.4 Programa BmaMV()}

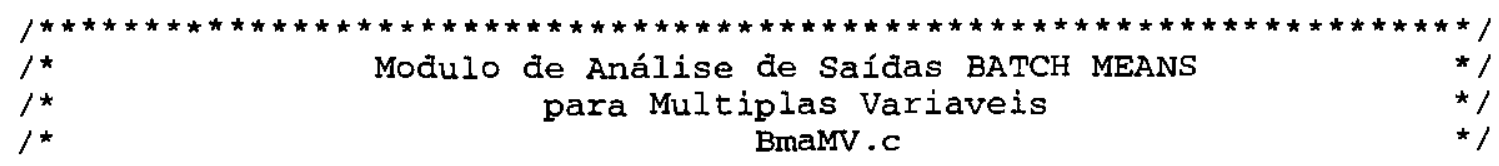




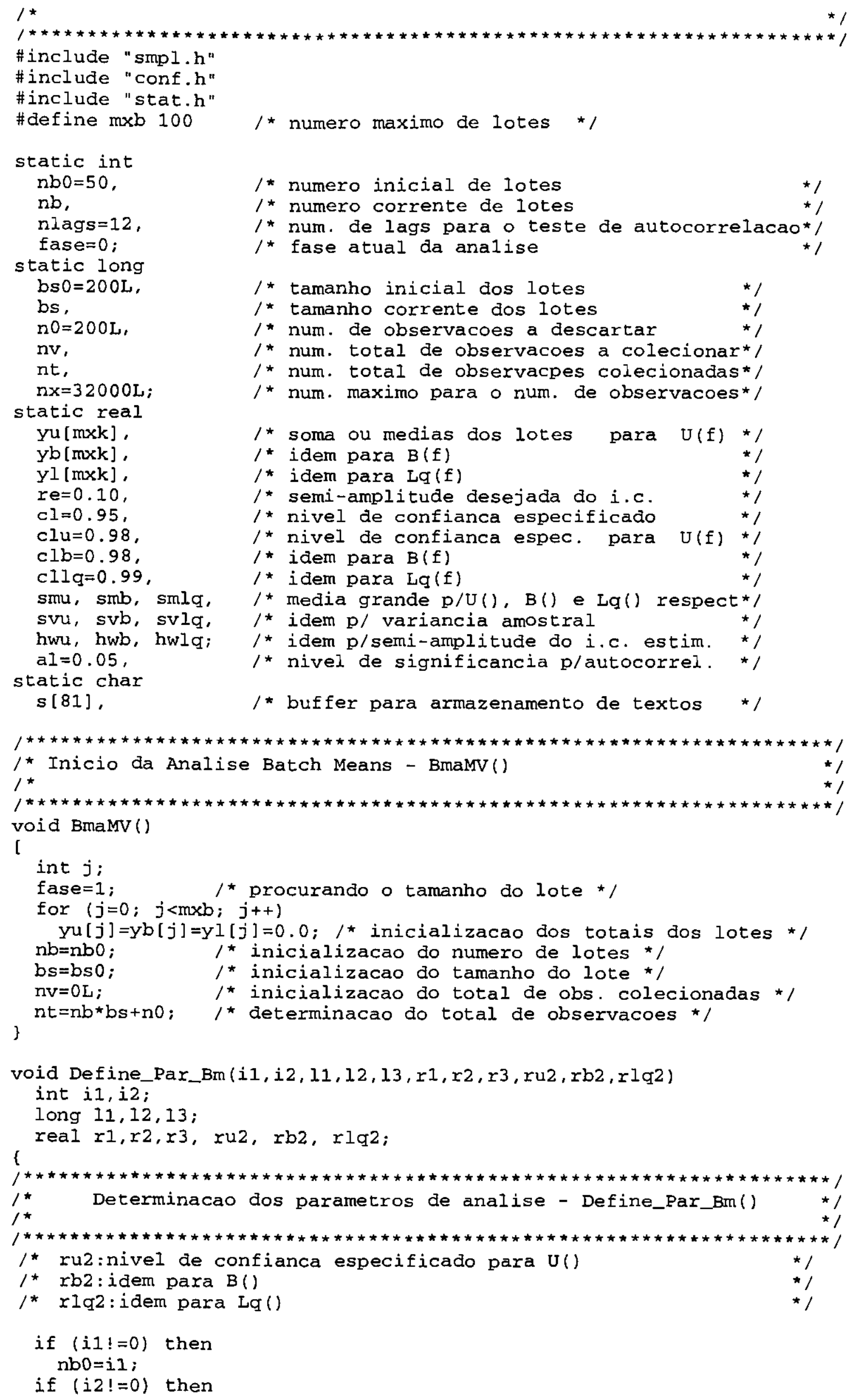




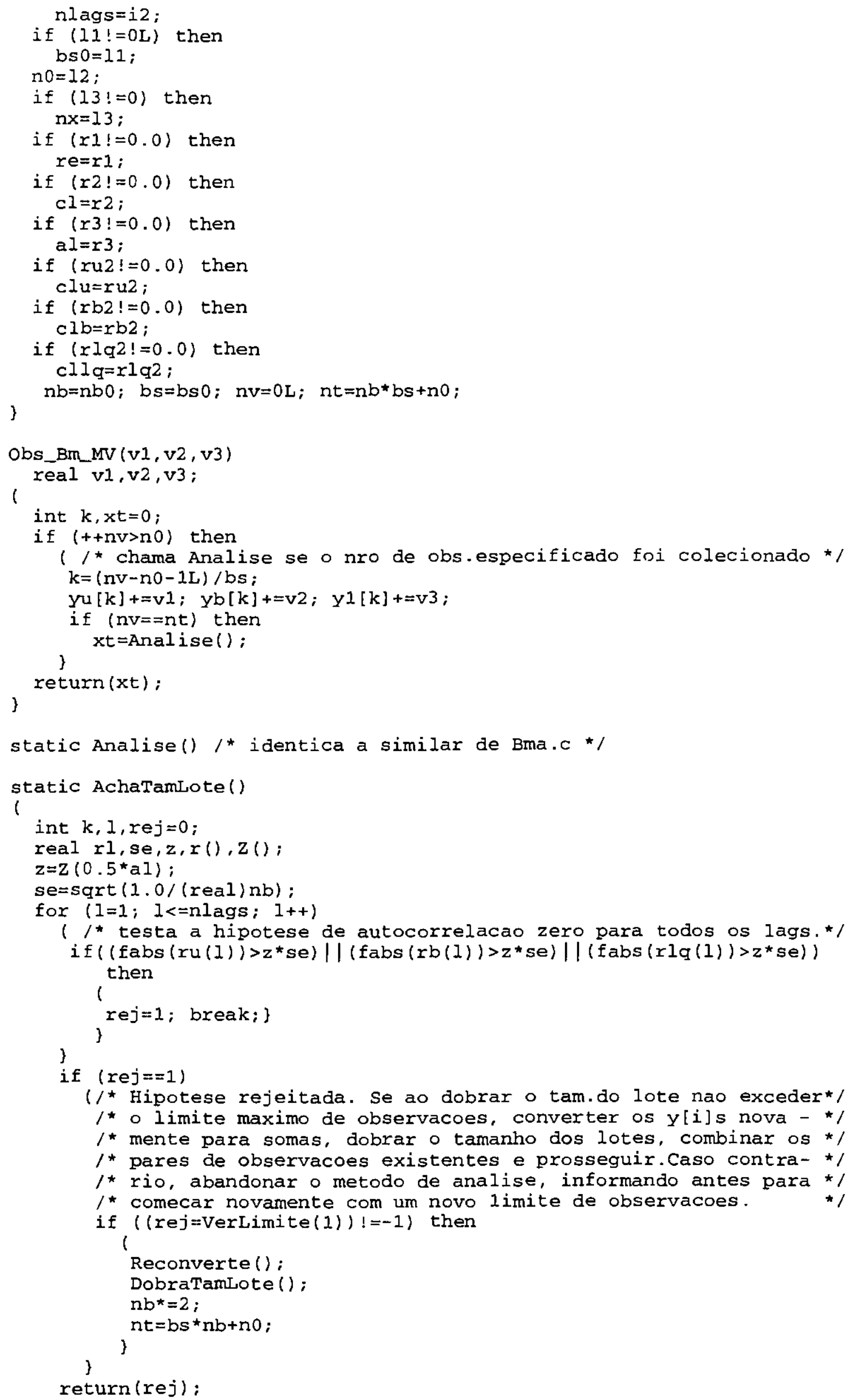




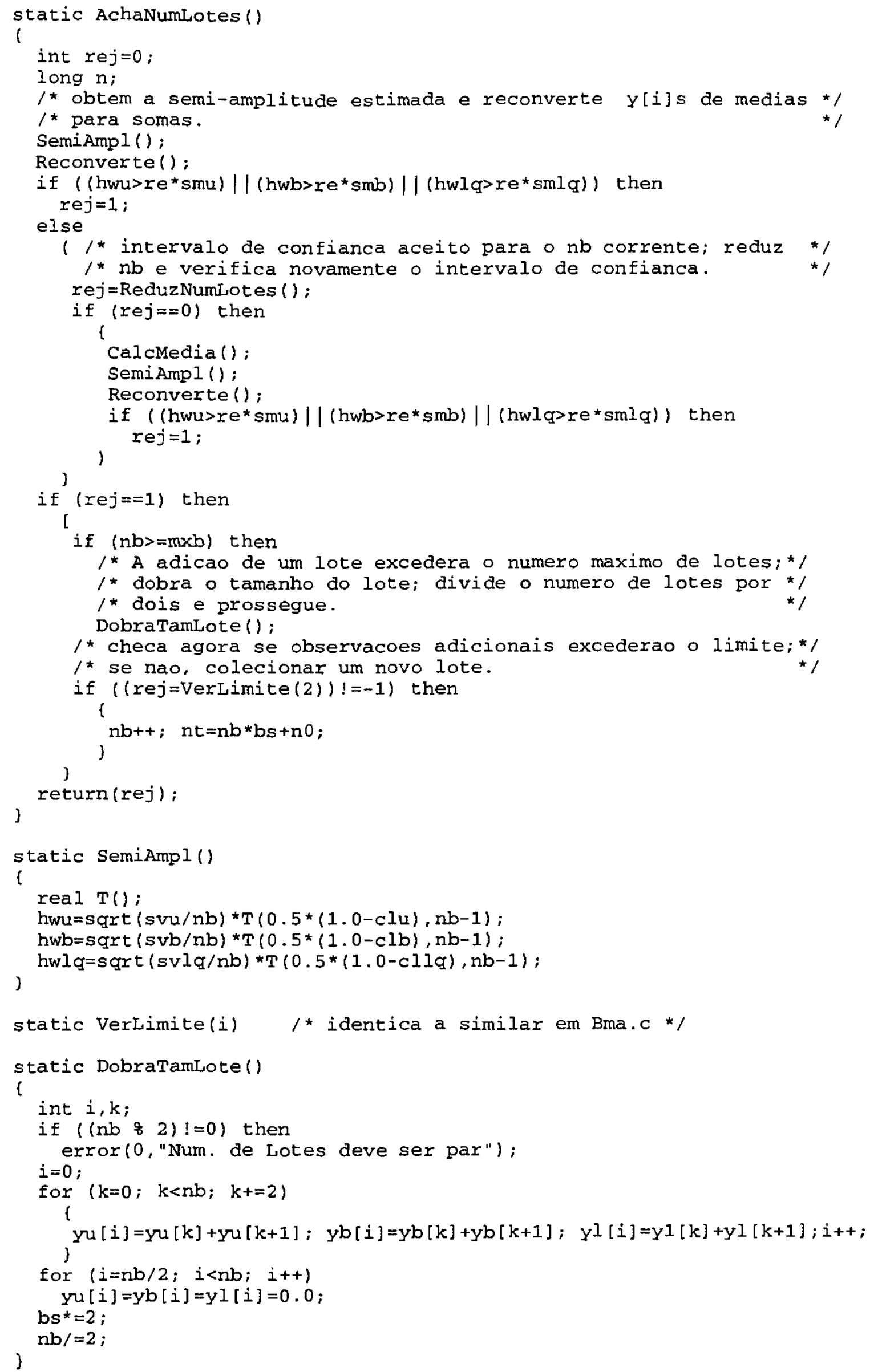




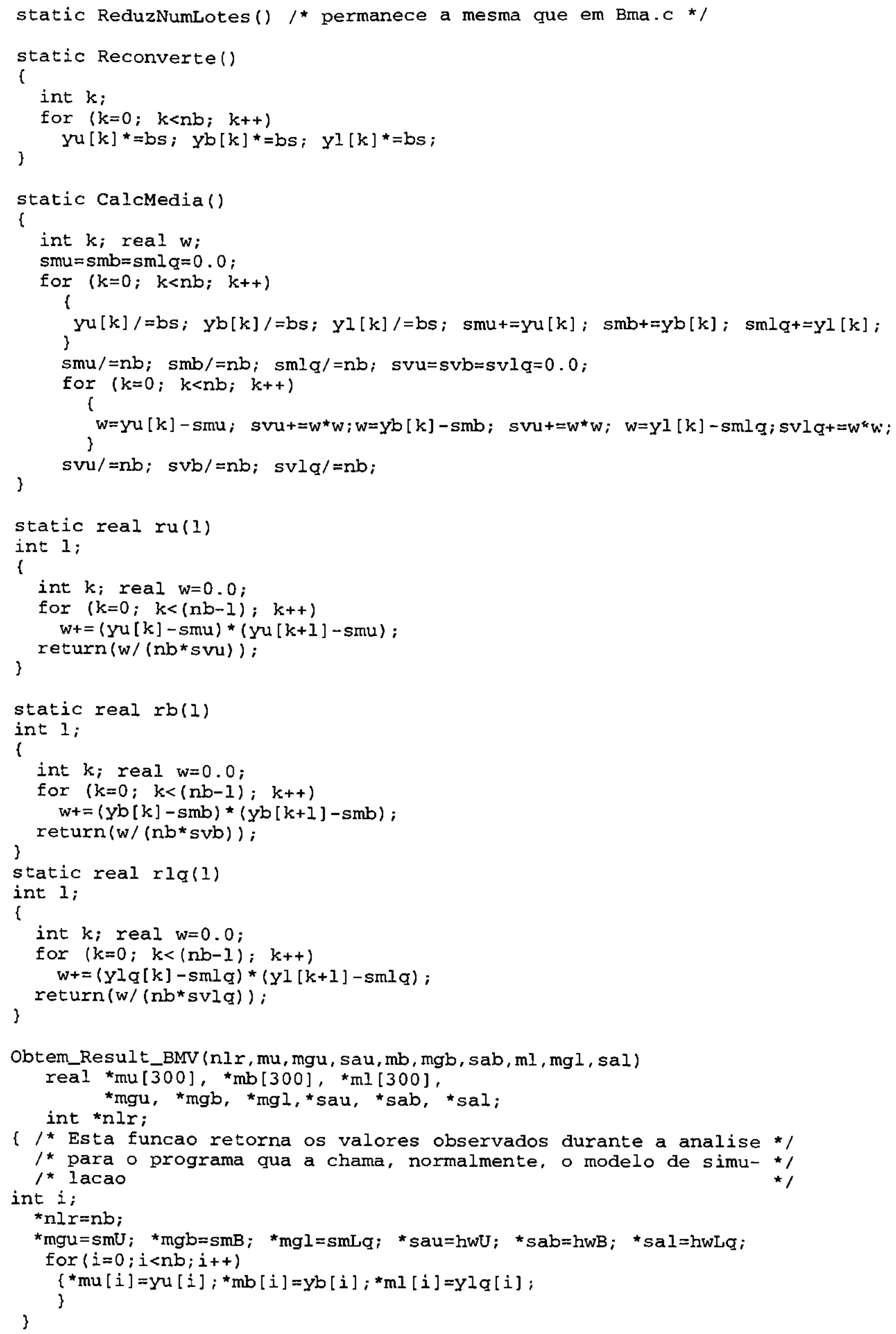




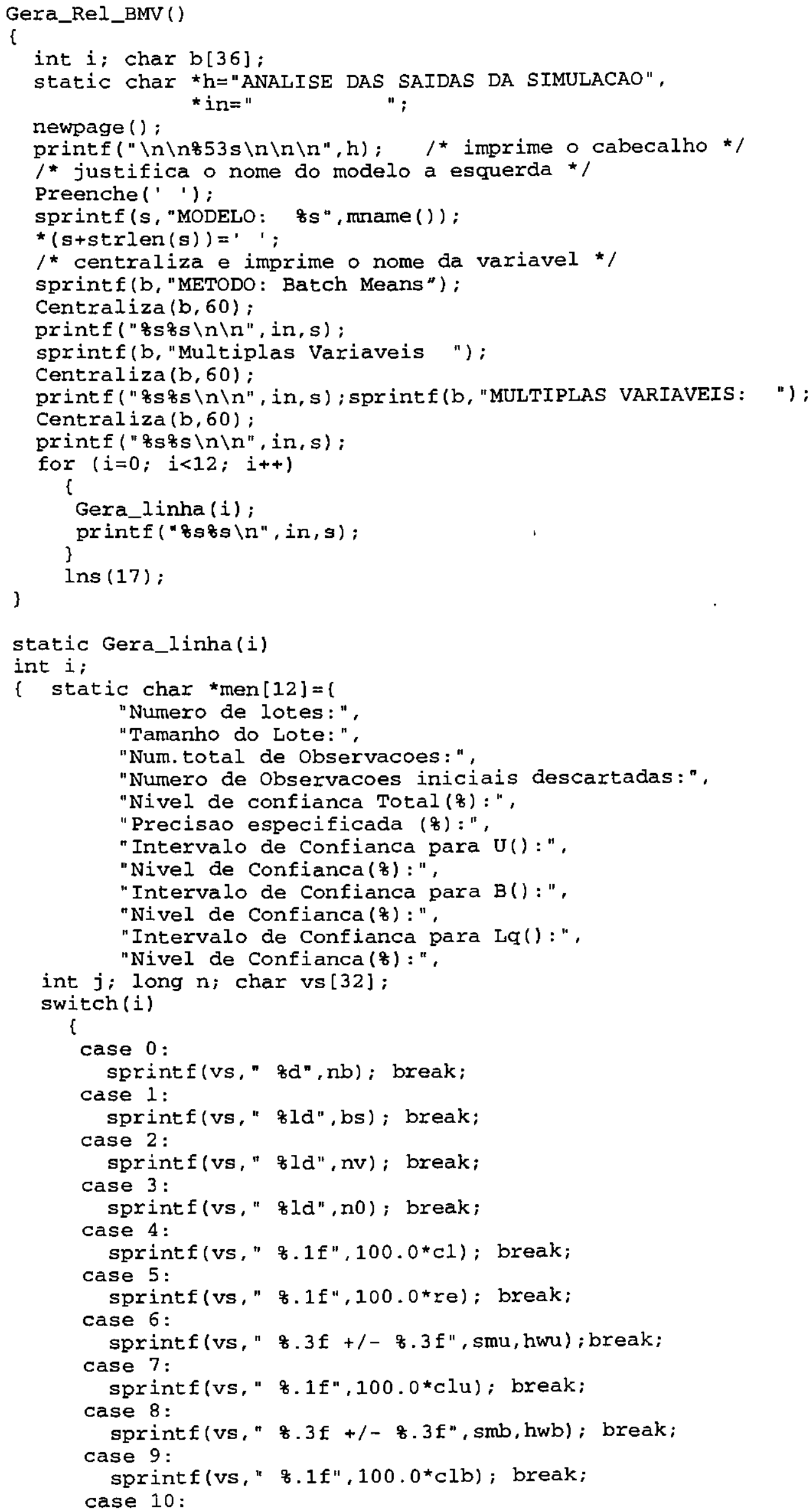


sprintf (vs, " \%. $3 f+/-\% .3 f "$, smlq, hwlq); break; case 11:

sprintf(vs," $8.1 f ", 100.0 *$ cllq); break;

)

\section{A.1.5 Programa Compara.c}

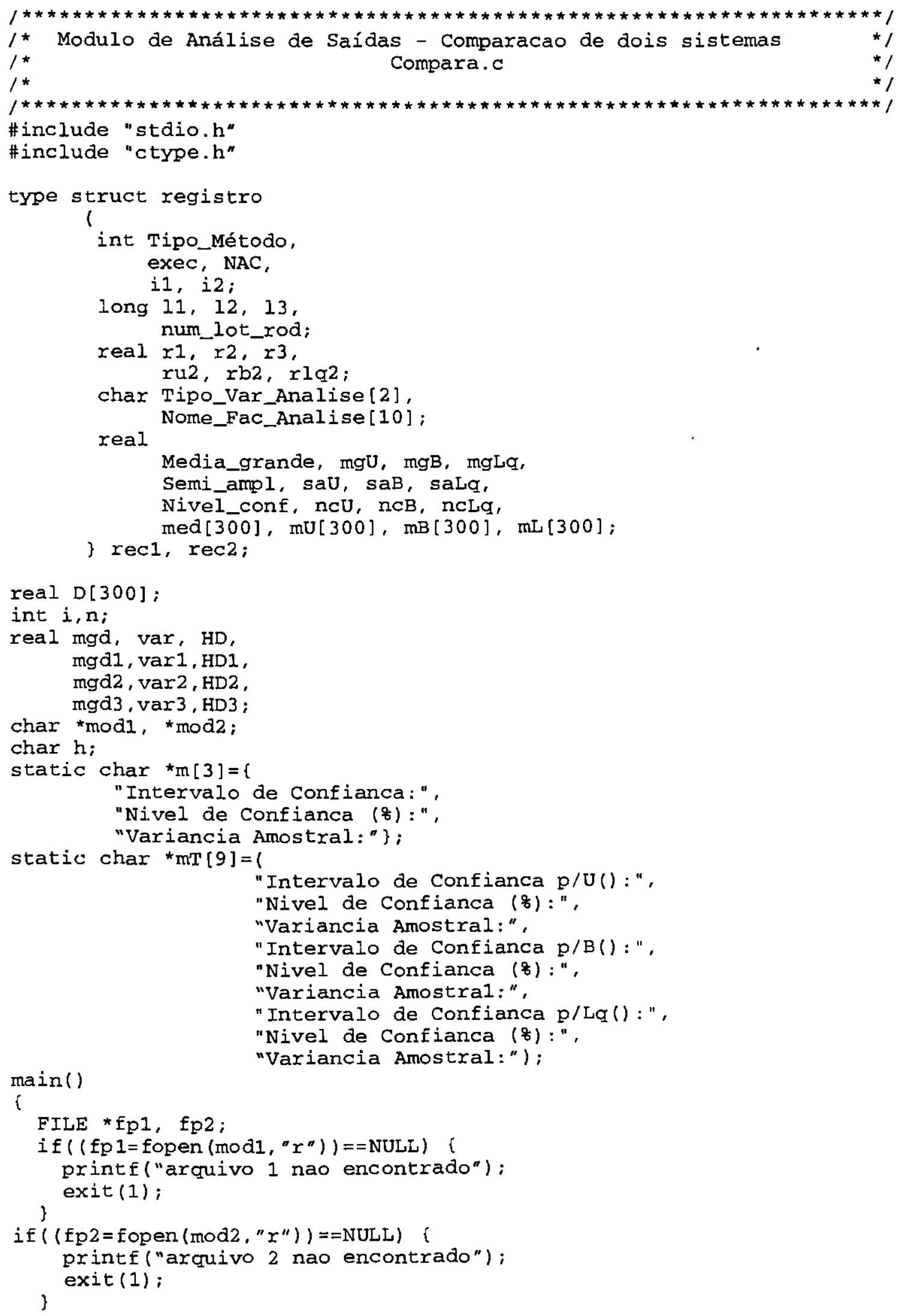




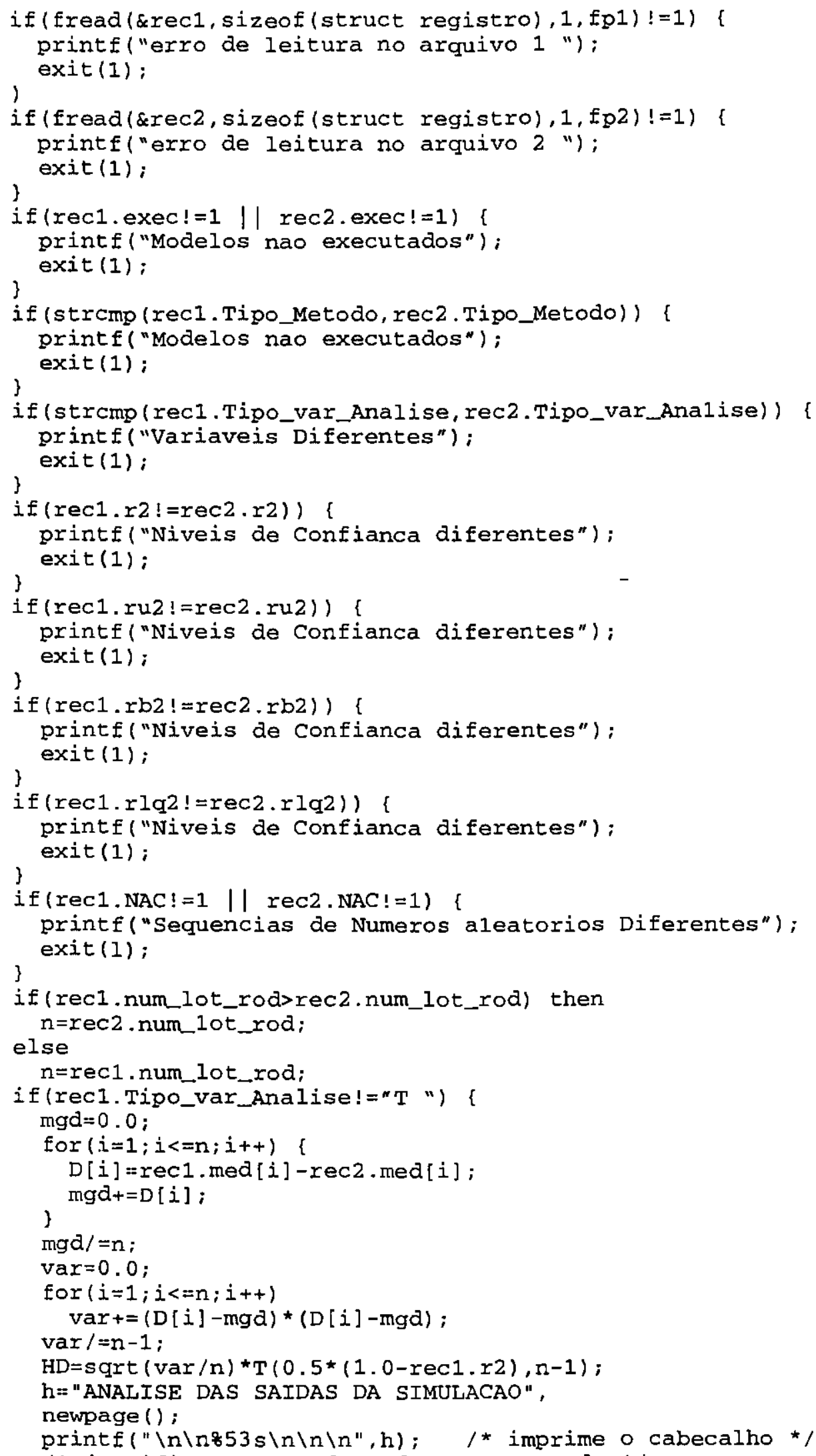




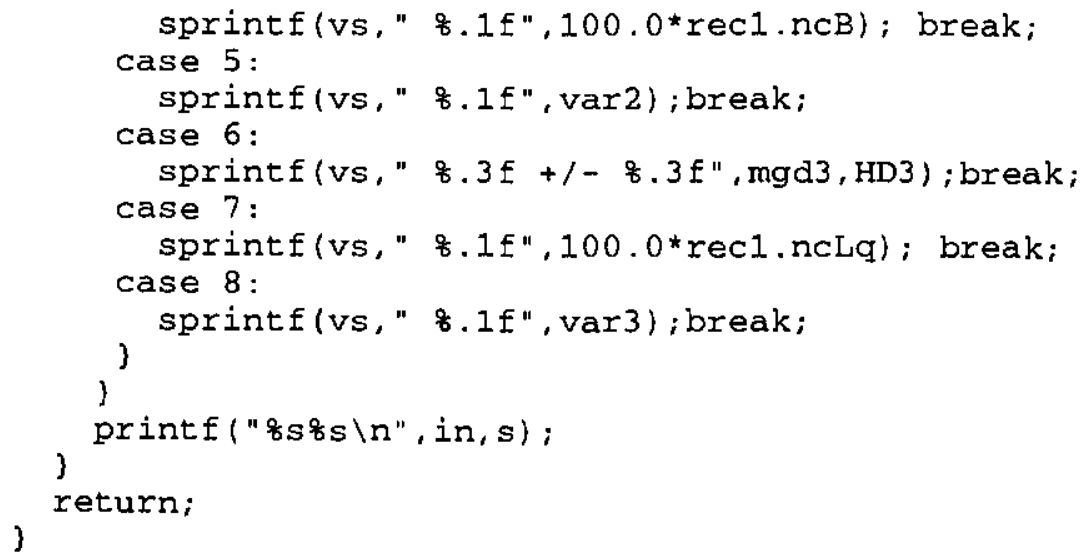

\section{A.2 Funções do smpl}

\section{A.2.1 Arquivo "Stat.c"}

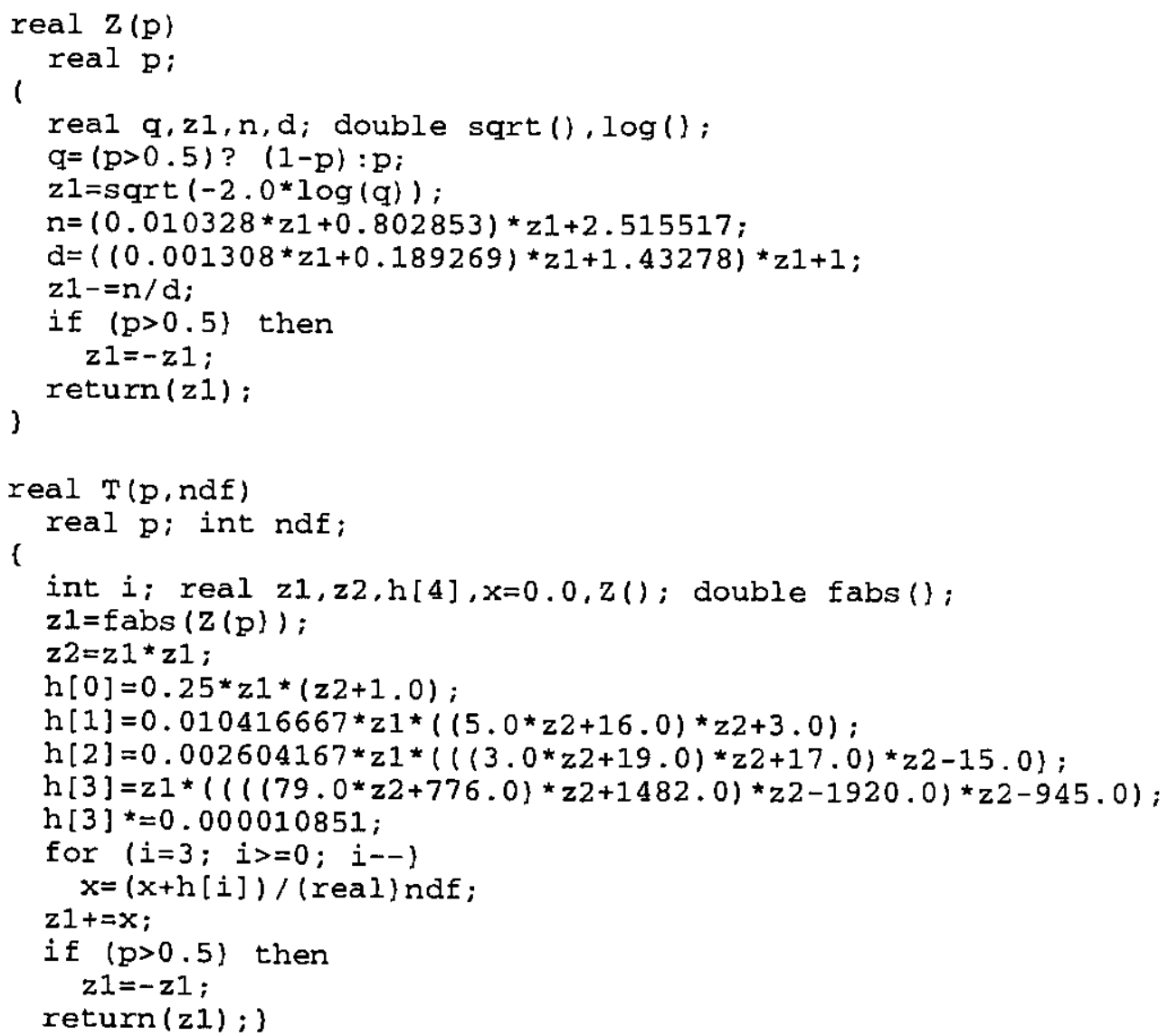




\section{APÊNDICE B}

\section{Listagem dos Códigos-fonte de algumas rotinas do Gerador de Aplicação do ASiA}

\section{B.1 Rotina Le_Gabarito()}

As alterações feitas nesta rotina aparecem em negrito.

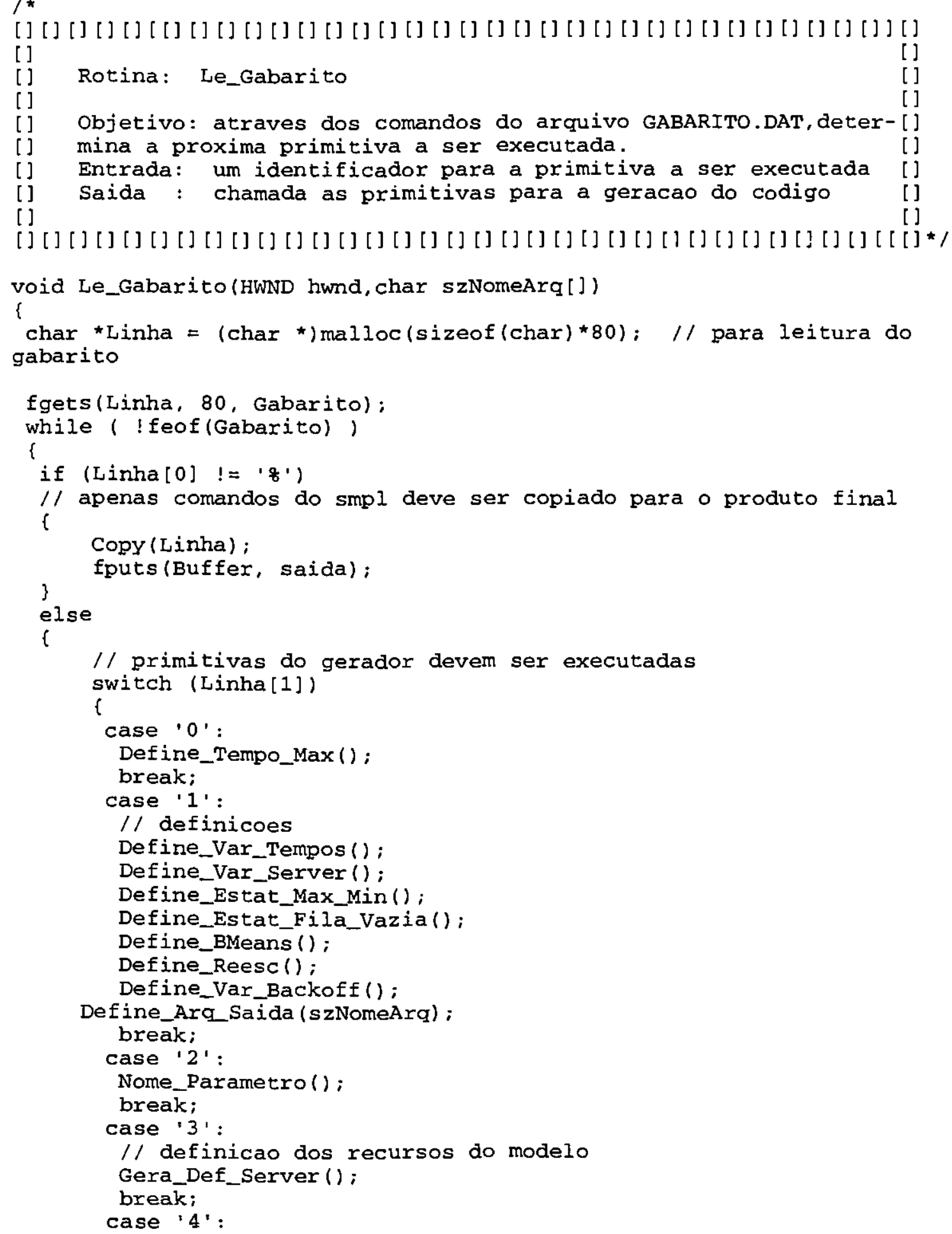


// escalona eventos antes do inicio da simulacao Gera_Primeiro_Evento(szNomeArq);

break;

case ' 5 ':

// Iimitante da simulacao

Gera_Loop ();

break;

case ' 6 ':

Gera_Cause();

break;

case '7':

Gera_Switch();

break;

case ' 8 ':

$/ /$ eventos que constituem a simulacao

Gera_Eventos (hwnd) ;

break;

case ' 9 ':

$1 /$ relatorio padrao

if (!strcmp(relat final, "sim") !=0)

break;

Gera_Relatorio_Final();

case 'A' :

// definicoes

Gera_Contadores (hwnd);

break;

$1^{\star}$ case ' $\mathrm{B}$ ' :

// ferramenta de depuracao

Gera_Trace();

break ;

case ' $\mathrm{C}$ ':

TEORICAMENTE NAO VAI HAVER TRACE */

// relatorio de estatisticas

if (Flag_Est_Max_Min)

break

Gera_Relat_Est_Max_Min();

case ' $D$ ':

// relatorio de estatisticas

if (Flag_Est_Fila_Vazia)

break

Gera_Relat_Fila_Vazia();

came 'E':

// metodo de analise de saídas

Gera_Matodo_Analime_Saida();

break,

Case ' $\mathrm{H}$ ':

// modifica os parametros de analise

Dofine_Param_Analise();

break,

case 'I':

// verifica se usuario definiu novas distribuicoes

Distrib_Tabela (szNomeArq);

break;

case ' $G$ ' :

// implementa warmup

Warmup () ;

break;

case 'L':

// trangfere o(s) valor(es) observados p/o metodo de analise Gera_Obs_Valores ();

break,

case ' $P$ ':

// imprime o relatorio da analise

Gera_Relatorio_Analise();

breaks?

case ' $Q$ ':

// grava os resultados na estxutura analise 


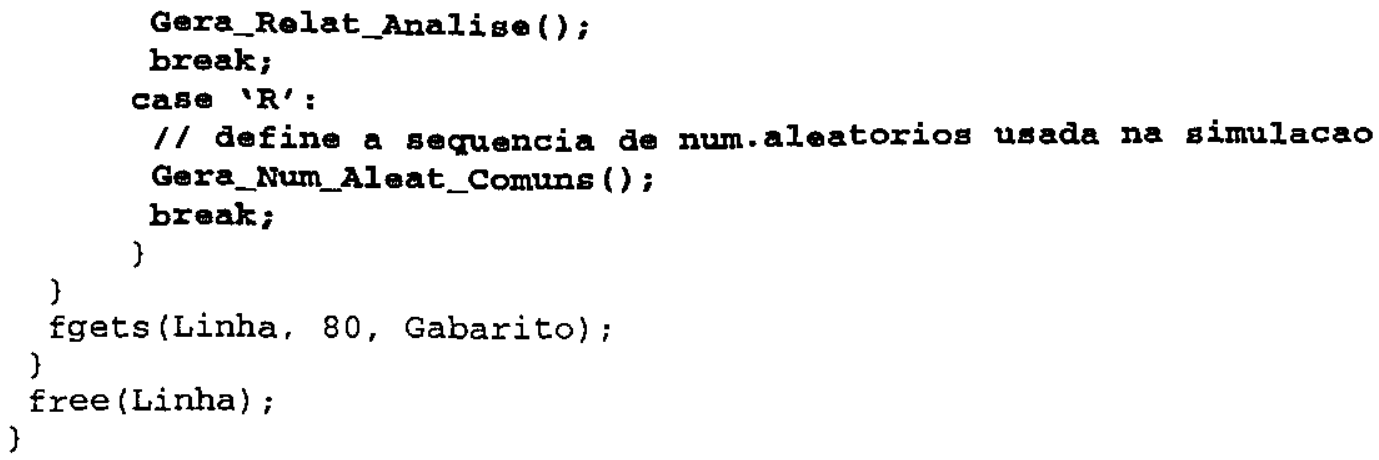

\section{B.2 Gabarito.dat}

\section{B.2.1 Versão Original}

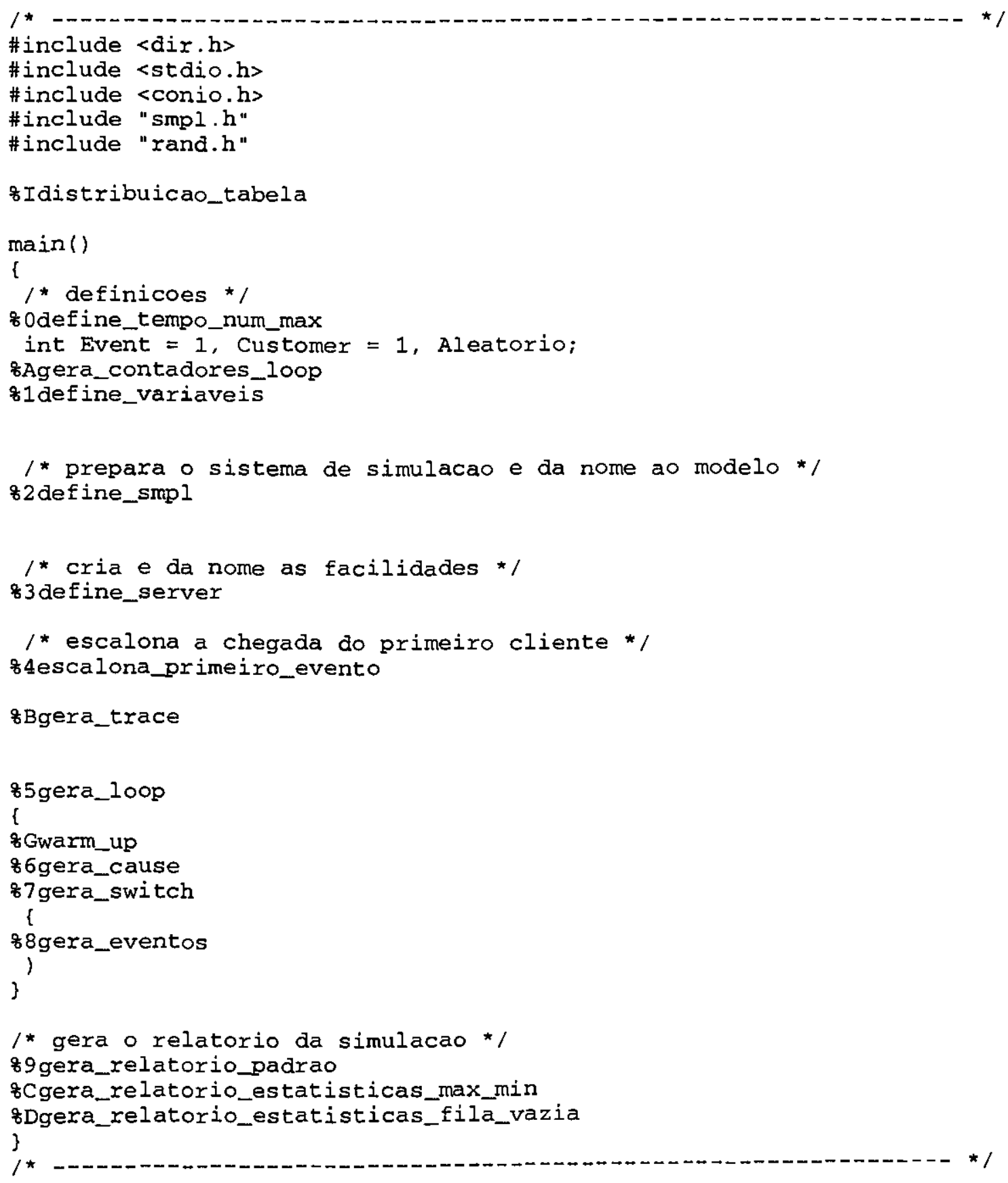




\section{B.2.2 Versão para o Módulo de Análise}

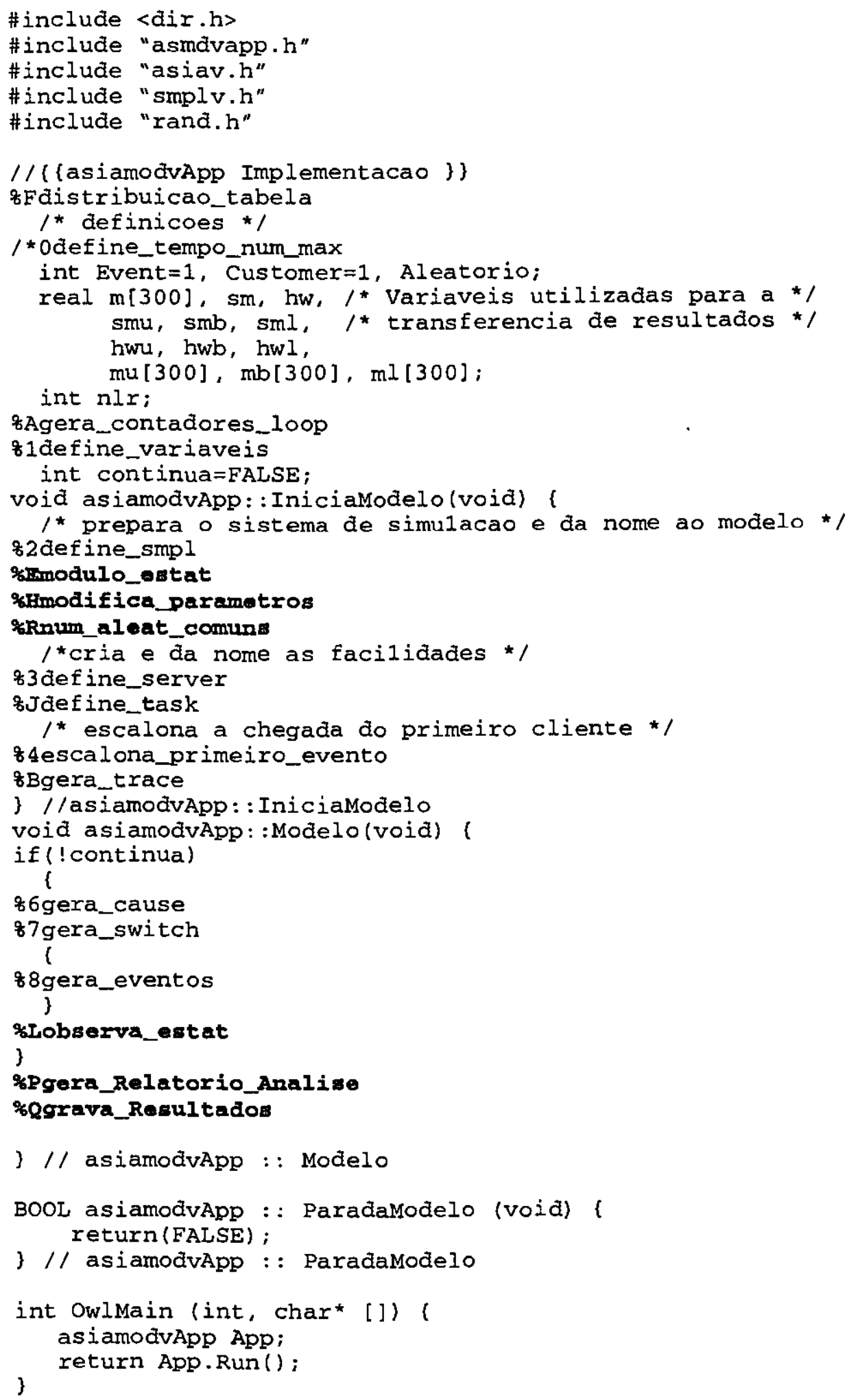




\section{B.3 Rotina Gera_Metodo_Analise_Saida}

\section{B.3.1 Versão Original}

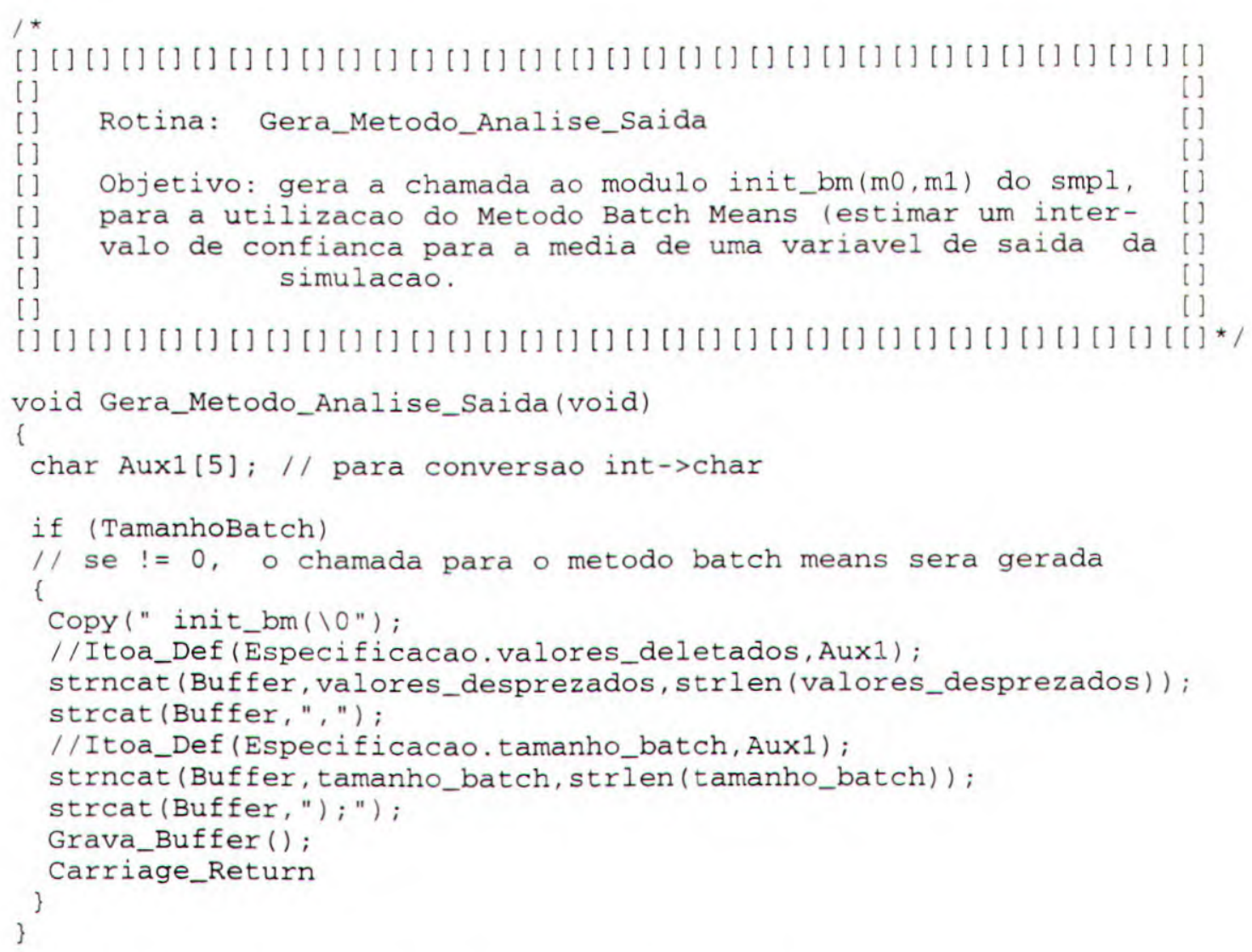

\section{B.3.2 Versão para o Módulo de Análise}

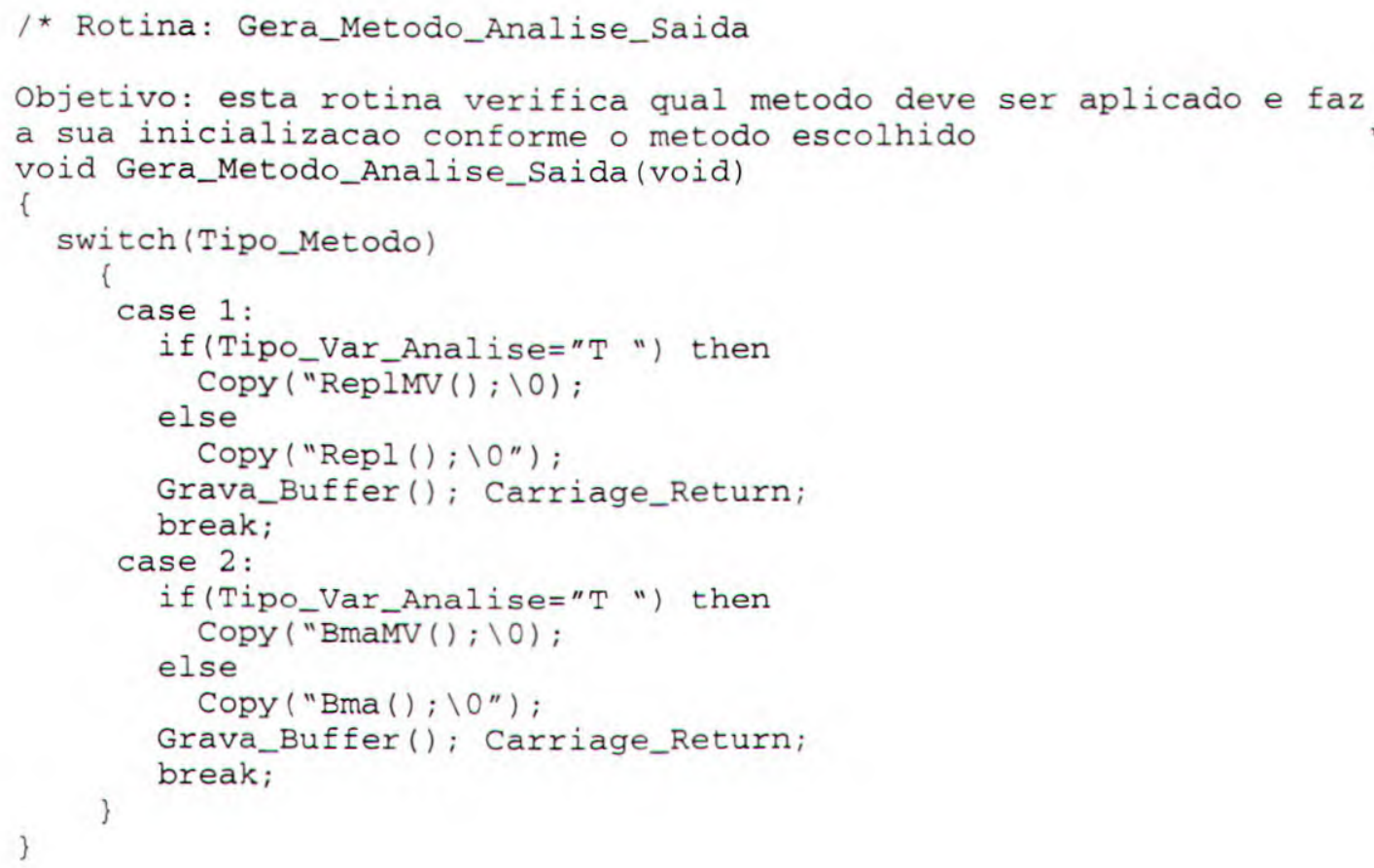




\section{B.4 Rotina Gera_Loop()}

\section{B.4.1 Versão Original}

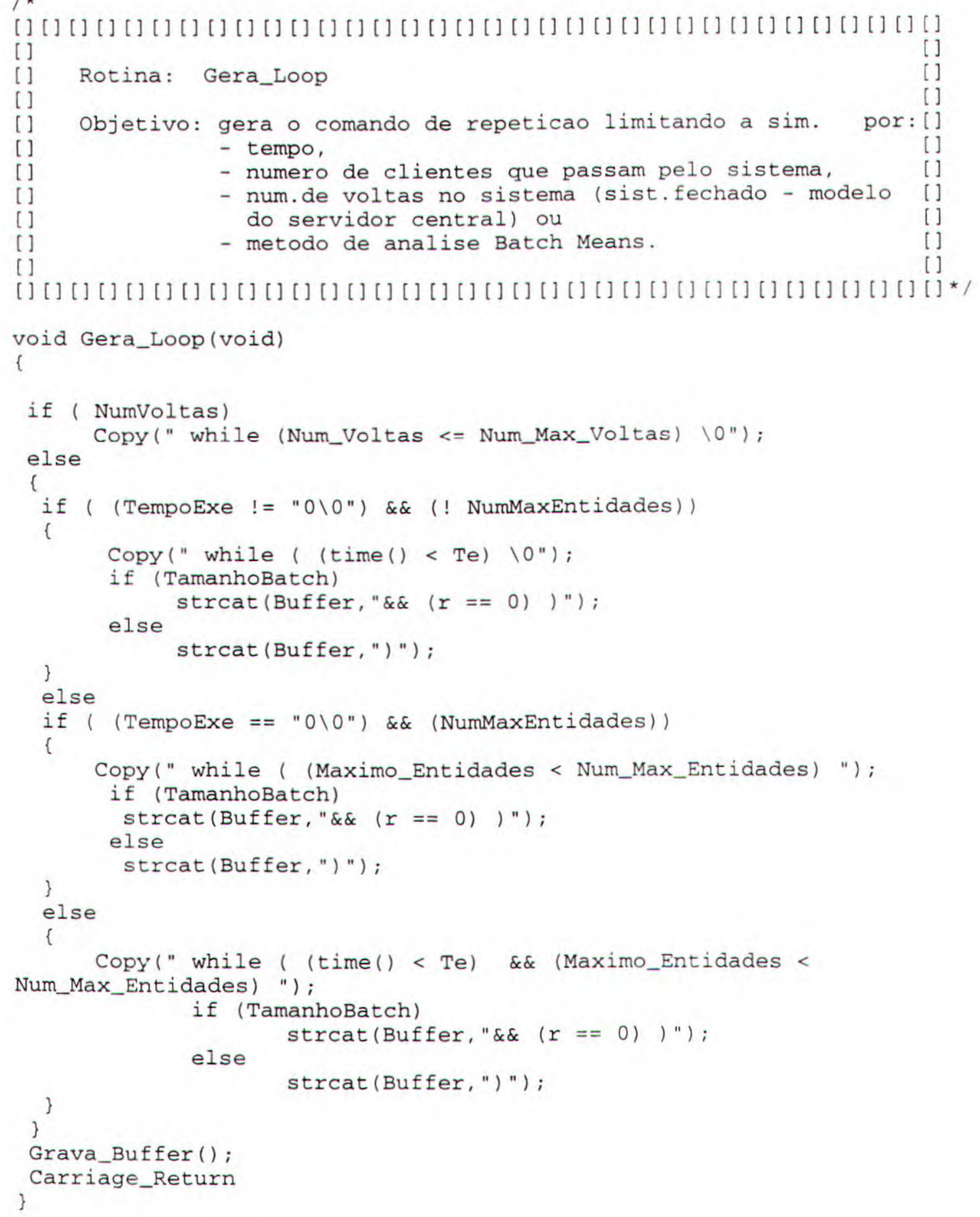




\section{B.4.2 Versão para o Módulo de Análise}

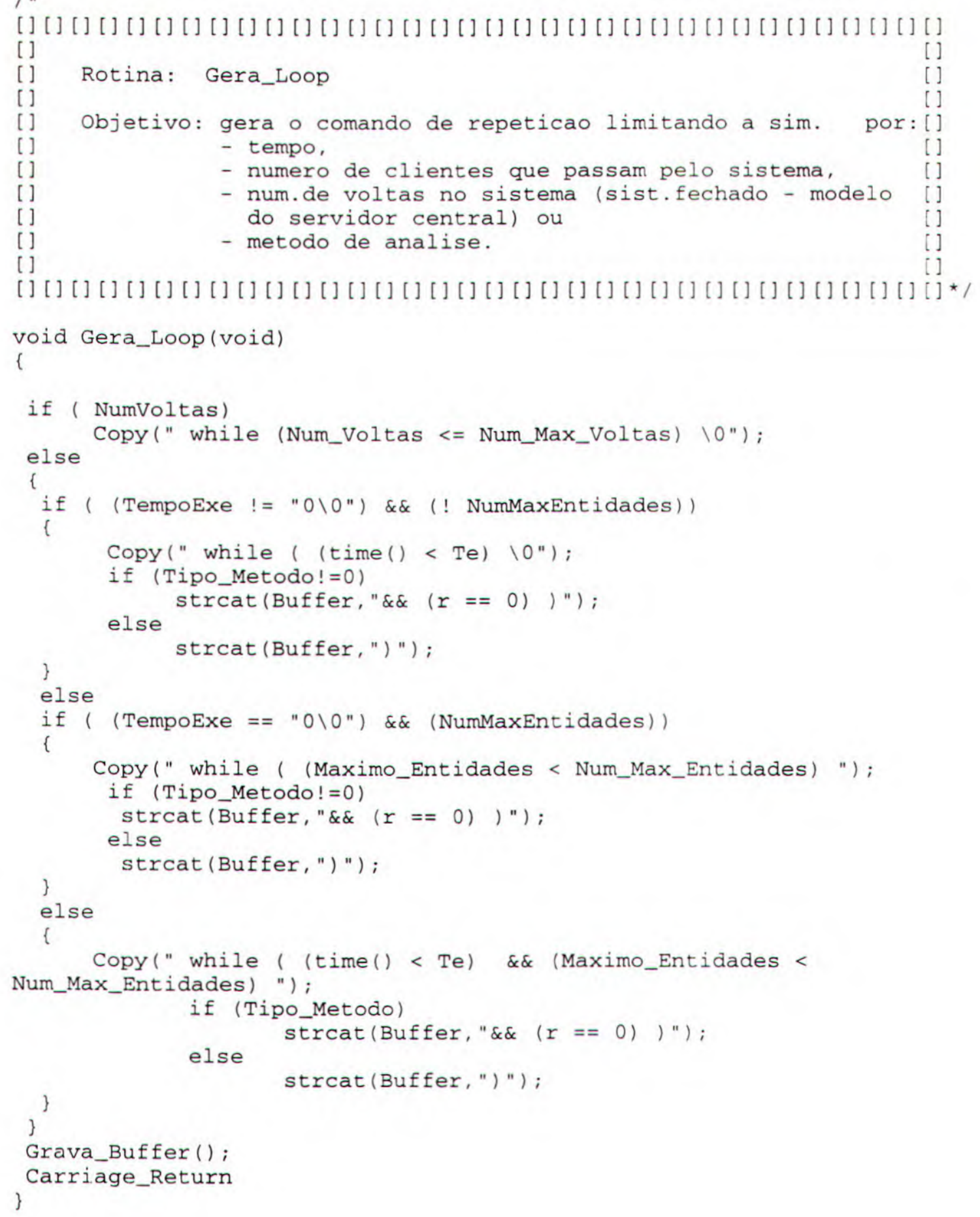

